\title{
ÉRTÉKTEREMTŐ TESTNEVELÉS
}

Tanulmányok

a testnevelés és a sportolás szerepéről

a Kárpát-medencei fiatalok életében

Szerkesztette: Kovács Klára 


\section{Oktatáskutatás a 21. században}

1.

$$
\text { A sorozatot szerkeszti: }
$$

\section{Prof. dr. Pusztai Gabriella}

Debreceni Egyetem, Neveléstudományok Intézete, egyetemi tanár Debreceni Egyetem, Nevelés- és Múvelődéstudományi Doktori Program, programvezetó 


\section{ÉRTÉKTEREMTő TESTNEVELÉS}

\section{Tanulmányok}

a testnevelés és a sportolás szerepéröl a Kárpát-medencei fiatalok életében

Szerkesztette: Kovács Klára

CHERD-H

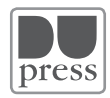

Debreceni Egyetemi Kiadó

Debrecen University Press 
A kötet megjelenését az NKA támogatta.

\title{
$\Pi<$
}

A kötet a Bolyai János Kutatási Ösztöndíj támogatásával készült

A kötet létrehozásában közremúködtek

a Debreceni Egyetem Felsőoktatási Kutató és és Fejlesztő Központjának (CHERD-H) és a Sporttudományi Koordinációs Intézet munkatársai.

\author{
Lektorálta: \\ Dr. habil. Rétsági Erzsébet, \\ Pécsi Tudományegyetem \\ Dr. Dóczi Tamás, \\ Testnevelési Egyetem \\ Angol nyelvi lektor: \\ Inántsy-Pap Ágnes
}

A borítón szereplő térképet Márkus Zsuzsanna készítette

Borítóterv és mưszaki szerkesztés:

M. Szabó Monika

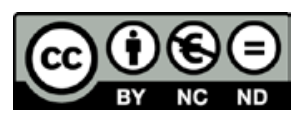

DOI 10.5484/kovacs_ertekteremto_testneveles

(C) Debreceni Egyetemi Kiadó Debrecen University Press, beleértve az egyetemi hálózaton belüli elektronikus terjesztés jogát is

ISBN 9789633185971

Kiadta: a Debreceni Egyetemi Kiadó, az 1795-ben alapított Magyar Könyvkiadók és Könyvterjesztók Egyesülésének a tagja www.dupress.hu Felelős kiadó: Karácsony Gyöngyi

A nyomdai munkálatokat

a Debreceni Egyetem sokszorosítóüzeme végezte 2016-ban 


\section{TARTALOM}

Előszó

I. fejezet: A testnevelés és a sport aktuális kérdései az iskolákban és azok falain kívül

Hamar Pál, Karsai István, Soós István:

Pedagógusi vélemények az iskolai testnevelés aktuális kérdéseiről 11

Fintor GÁbor:

Tanulói nézetek a mindennapos testnevelésről észak-alföldi általános iskolákban

BAlogh LÁszló, Kiss Mihály:

Merre tovább testnevelőtanár-képzés? 36

Orosz Róbert, JónÁs Péter:

Új generáció - új szemléletek és utak a sporttehetség gondozásában 46

Fenyő Imre, Rábai DÁvid:

A sporttehetség-gondozás jogszabályi környezete - a sportakadémiák

Magyarországon

Keresztény István, Greba Ildikó:

A testnevelési kategóriába sorolás helyzetelemzése

egy kárpátaljai oktatási intézményben

II. fejezet: A testnevelés és a sport értékteremtő és -átadó szerepe

Bodnár Ilona, Perényi Szilvia:

Értékháló az iskolai testnevelés körül 101

Urbinné Borbély Szilvia:

A testnevelők és a testnevelés tantárgy presztízse a megváltozott testkulturális környezetben

Nagy Ágoston, Fintor Gábor, Urbinné Borbély SZilvia:

Az egyetemi testnevelő tanárok tevékenységprofiljára ható testkulturális változások

Hideg Gabriella:

Fair play, neked mit jelent? Kárpát-medencei fiatalok véleménye a fogalomról 
Nagy Beáta Erika, Kovács Karolina Eszter:

Serdülők egészségmagatartása a sport és családszerkezet függvényében

Sorin Buhaș:

Sports and Physical Education - Determinants of Social Integration

Among Students in Romania

III. fejezet: A testnevelés és sport helyzete, szerepe a Kárpát-medencében

KovÁcs KLÁra:

Közép-kelet-európai hallgatók sportolásának szociokulturális jellemzői

Kozma Miklós, Szabó Ágnes, Huncsik Péter:

A budapesti egyetemisták sportolási szokásai - 2004-2014

Lepeš Josip, Halasi Szabolcs, Stajer Anita:

A testnevelés és a sport egészségmegőrző hatása a vajdasági fiatalok értékrendszerében

Dobay BeÁta:

Rekreációs sporttevékenységek jelenléte a szlovák felnőtt

lakosság körében

Greba Ildikó, Greba Anna:

A testnevelés és a sport presztízshelyzete Kárpátalja magyar középiskoláiban 219

Abstracts 237

Szerzőink 


\section{ELŐSZÓ}

\section{Témavezetőm, prof. dr. Szabó Ildikó emlékére}

Az Eurobarometer 2013 adatai szerint a magyar lakosság 44\%-a soha nem végez testedzést, ezzel elmaradva az EU-s átlag mögött. Ehhez szorosan kapcsolódik, hogy a magyar lakosságra igencsak jellemző inaktivitás következtében számos betegség előfordulását tekintve a magyarok élen járnak más EU-s országokhoz viszonyítva. Ezek a negatív tendenciák azonban nemcsak hazánkban, hanem a szomszédos országokban is érvényesülni látszanak. A statisztikai mutatók hatására számos kormányzati döntés született és kezdeményezések indultak annak érdekében, hogy minél többen vehessenek részt rendszeres fizikai aktivitásban. A jelenség azonban fontossá teszi az olyan tudományos kutatásokat is, amelyek célul tűzik ki a sportolás és testnevelés társadalmi, oktatási, pedagógiai, gazdasági és politikai összefüggésrendszerének feltárását, illetve a különböző programok következményeinek, hatékonyságának vizsgálatát. Emellett fontos megismerni a magyar lakosság vagy egyes régiók, társadalmi csoportok inaktivitásának okait, melyek alapul szolgálhatnak további programok kidolgozásához.

A Debreceni Egyetem Felsőoktatási Kutató és Fejlesztő Központjában (CHERD-H) az elmúlt években több adatfelvételt készítettünk a magyar-román-ukrán-szerb határ menti régióban, melyekben többek között megvizsgáltuk a fiatalok sportolási szokásait és a sportolás hatásait egészségmagatartásukra, jóllétükre, tanulmányi eredményességükre. E tanulmánykötet célja, hogy a testnevelés, a sportolás értékteremtó és -átadó szerepéhez kapcsolódóan kapjunk választ a fenti kérdésekre országos, régiós és nemzetközi adatok felhasználásával és tendenciák, gyakorlatok bemutatásával. A kötet bemutatja, hogy mi zajlik a testnevelésórákon, az egyénileg és közösségben végzett sporttevékenység közben, milyen értékeket, készségeket, képességeket sajátítanak el a fiatalok testmozgás végzése közben, mire nevel, hogyan kell foglalkozni a sporttehetségekkel, hogyan viszonyulnak a fiatalok a sportoláshoz, testneveléshez, tanáraikhoz, s miért pont úgy, illetve milyen társadalmi, egyéni, gazdasági tényezők befolyásolják a fiatalokat a fenti kérdésekben, sportoláshoz kapcsolódó döntéseikben.

A sportolás lehetőséget nyújt azoknak az értékeknek, normáknak, jelképeknek az elsajátítására, melyek elengedhetetlenek a társadalmi beilleszkedéshez. A sportoló csoportba érkező új tag az addigiakhoz képest teljesen más szociális közegbe kerül. Új érték- és normarendszer veszi körül, vagy legalábbis az eddig megismert értékek másfajta összefüggésekben jelennek meg számára (Gombocz 2008). A sportolás megtanít tisztelni a szabályokat, saját magunkat, a többi embert, az egészséges fair play-en alapuló versenyt (Izzo 2005). Segít megtanulni a fizikai, erkölcsi és kulturális alapelveket, hozzájárul a jellem fejlődéséhez. Megtanulják tisztelni egymást, megismerni a másikat és összehasonlítani önmagukkal, összemérni tudásukat legális eszközökkel (Gombocz 
2010). Kötetünk arra keresi a választ, hogy hogyan jelenik meg ez az értékátadó funkció a testnevelésórákon és képzésben, a sportklubokban, a közösségi és egyéni sportolás révén hazai és nemzetközi kontextusban. Azonban számtalan társadalmi, gazdasági, pedagógiai tényező befolyásolhatja ezt a folyamatot, amelyek feltárása szükséges ahhoz, hogy megismerjük, mi zajlik a testnevelésórákon, hogyan nevel a sportolás, $\mathrm{s}$ felismerjük az esetleges problémákat, hátrányokat, negatív folyamatokat.

Fontos hangsúlyt fektetünk a sporttevékenységek közösségteremtő hatására. Akár a testnevelésóráról, akár a hasznos szabadidő-eltöltés céljából alkalmanként összejövő, sportolni vágyó fiatalok baráti társaságáról beszélünk, ahhoz, hogy a testmozgás örömteli, élvezetes, fizikailag és mentálisan hasznos legyen, motiváljon a rendszeres testedzésre akár egy életen át, fontos a légkör, a tagok egymásra figyelése, elfogadása, hatékony kooperációja kortól, nemtól, etnikai, társadalmi háttértôl függetlenül. A közösen végzett testmozgás toleranciára, elfogadásra nevel, megtanít a csapatmunkára, a kemény munka tiszteletére, fejleszti a vezetői képességeket, de leginkább arra tanít meg, hogyan kell másokkal bánni, együttmúködni, kapcsolatot kialakítani és fenntartani. Ebből kifolyólag a közösségben végzett sportolás az életre szóló barátságok vagy éppen közeli ismeretségek, így a társadalmi tóke egyik forrása, melyet kamatoztatni lehet az élet más területein is. De ennél sokkal fontosabb, hogy egy sportoló közösségnek csak akkor válhat valaki tagjává, ha elfogadja az ezekben érvényes norma- és értékrendszert, betartja a szabályokat, mindezek pedig nemcsak az egyén jellemének fejlődéséhez és a társadalmi beilleszkedéshez járulnak hozzá, hanem egy integráltabb, befogadóbb, egységesebb társadalomhoz is, hiszen megvédenek a társadalmi elgyökértelenedéstől, devianciáktól.

A kötet egyik legnagyobb újszerû́sége, hogy nemcsak az oktatási intézményekben és ezek falain kívül vizsgálja meg a testnevelés és sportolás szerepét, hanem kilép regionális szintre, sőt az ország határain kívülre, egy nemzetközösséghez tartozónak kezelve az azonos nemzeti identitással, nyelvvel, kultúrával rendelkező anyaországi és határon túli magyar fiatalokat a Kárpát-medencében. Az első fejezetben olyan tanulmányokat olvashatunk, amelyek a diákok, sportolók, edzők és a (leendő) testnevelők szempontjából elemzi azt, hogy mi zajlik az iskolák falain belül és kívül a testnevelésórákon, a képzésben, illetve a sportoláshoz kapcsoló extrakurrikuláris programokon. A második fejezet tanulmányai a testnevelés és sportolás értékteremtő és -közvetítő folyamatában zajló jelenségeket mutatják be. A harmadik fejezet tanulmányai országos, regionális és nemzetközi viszonylatban vizsgálják meg a sporttevékenységek társadalmi, gazdasági, pedagógiai aspektusait a Kárpát-medencében.

Kötetünket egyaránt ajánljuk a sport és testnevelés megújitásáért, fejlődéséért dolgozó oktatóknak, kutatóknak, tanároknak, edzőknek, döntéshozóknak és mindenkinek, akinek fontos a hazai és határon túli sport és testnevelés helyzete, szerepe és a magyar fiatalok sportoló nemzetté válása.

Debrecen, 2016 szeptembere 


\section{FEJEZET}

\section{A testnevelés és a sport aktuális kérdései az iskolákban és azok falain kívül}





\title{
Hamar Pál, Karsai István, Soós István
}

\section{Pedagógusi vélemények az iskolai testnevelés aktuális kérdéseiről}

\begin{abstract}
Absztrakt
A tanulók körében a testnevelés ma már nem tartozik a legkedveltebb tanórák közé. A testnevelők testi neveléssel kapcsolatos visszafogott szerepvállalása a jellemző, amiben pedagógiai hiányosságok is szerepet játszhatnak. Vizsgálatunkban a testnevelés tantárgy és a testnevelő tanárok helyzetéről feltett kérdésekre kerestük a választ olyan témákban, mint a testnevelés státusza a többi tantárgyhoz, illetve a testnevelők helyzete a többi tanárhoz viszonyítva. Kérdést fogalmaztunk meg azzal kapcsolatban is, hogy léteznek-e olyan központi intézkedések, amelyek az átmenetet biztosítják a kötelező testnevelés és az iskolán kívüli sportolás között. Keresztmetszeti vizsgálatunk során a csoportos rétegzett mintavételi eljárást alkalmaztuk $(\mathrm{N}=1161)$. Vizsgálati módszerünk a kérdőíves felmérés volt. Az adatfelvételre a 2013/14. tanévben került sor. Az adatfeldolgozás - az alapstatisztikai adatok (gyakoriságok) megadása mellett - Khi-négyzet-próbával és Fisher exact teszttel történt. A vizsgált személyek azon álláspontra helyezkedtek, hogy a testnevelés tantárgy státusza nem éri el a többi tárgyét. A testnevelést oktatók több mint egynegyede szerint a testnevelő tanárok helyzete rosszabb, mint a többi tanáré. A kötelező testnevelés és az iskolán kívüli sportolás közötti átmenet még mindig nem kielégítő.
\end{abstract}

\section{Bevezetés}

A testnevelés tantárgy (műveltségi terület) jelentős változásokon ment keresztül a rendszerváltozást követően. Ma már nem elsősorban a tornaterem négy fala közé zárt, az iskolától távol eső sportpályákon zajló testgyakorlást jelent, hanem egy olyan sajátosan összetett tantárgy, amely magában foglalja az egészségmegőrzés (prevenciós jellegü) és az egészség-helyreállítás (rehabilitációs jellegű) eszközeinek mozgásos formáit és a mozgásokhoz kapcsolódó elméleti ismereteket. Maga a sporttevékenység speciális kognitív, affektív-emocionális és motoros tudást biztosít. Mindezek következtében az iskolai testnevelés és sport nevelési hatásai jelentősen meghaladják a tananyag elsajátításának a szintjét (Gergely 2007).

A testnevelés paradigmaváltásának nemcsak magyarországi, hanem nemzetközi vonatkozásai is tetten érhetők. Egyes európai országokban a testnevelés tantervi kérdéseinek újragondolása zajlik, mégpedig az egész életen át tartó tanulás, az egészséges jóllét (healthy well-being) és a fizikailag aktív életvitel tekintetében. Ezek a célok a testnevelés tartalmi fejlesztésének az igényét is magukkal hozzák mind a társadalom, 
mind az egyén szintjén. Felértékelődik a helyi (regionális) szintủ szabályozás a testnevelési tantervek területén is (Hardman 2009).

Az 1989/90-es magyarországi fordulat a tantervi köz- és tudományos gondolkodásban is erőteljes szemléletváltást hozott. Ennek egyik oka arra vezethető vissza, hogy „[a]z iskolák és tanulók közötti különbségek további növekedése, az elmaradók nagy száma, teljesítményük elégtelensége egyre aggasztóbb következményekkel járt. Válsággócok alakultak ki a képzés számos területén a környezetismerettől a történelmen át a testnevelésig” (Ballér 1996: 152). Az egyik „válsággóc”, a testnevelés, a rendszerváltozást követő mintegy másfél évtizedben a magyar közoktatás mostohagyermeke volt. Erre az időszakra tehetô a műveltségi területek arányaiból levezethető heti másfél óraszám, vagy a tantárgy osztályozása megszüntetésének ötlete is.

Gergely Gyula egy 2002-es tanulmányában megállapítja, hogy ebben az időszakban a mozgás még mindig nem vált az iskolai élet szerves részévé, nem alapérték. A diáksportversenyek minden szintjén csökkent a versenyeken részt vevő fiúk és lányok száma. Ez arra figyelmeztet - írja -, hogy a kellő ingergyakoriság hatására felkeltett tanulói érdeklődés feltételeit minden tekintetben biztosítani kell, különben nem várható el, hogy nagyobb arányban vegyenek részt a tanulók a tanórán kívüli tevékenységben. Vissza kell adni a testgyakorlás rangját!

Ezt a sajnálatos regresszív trendet erősíti meg Kovács Klára (2015), amikor - Gombocz Jánosra hivatkozva - megjegyzi, hogy az iskolában a testnevelés ma már nem tartozik a legkedveltebb tanórák közé. A tanárok testi neveléssel kapcsolatos visszafogott szerepvállalása a jellemző, amiben nagy valószínűséggel pedagógiai hiányosságok is szerepet játszhatnak.

A tantárgy rangjának visszaállítása elodázhatatlan feladat, mivel a felnövekvő nemzedék egészségi és edzettségi mutatói rendkívül rossz képet mutatnak. Magyarországon ijesztő méreteket ölt az inaktív sportérdeklődés, s mindennapjaink egyre jellemzőbb kísérójelenségévé válik a negatív testedzési hajlam. Emellett, vagy éppen ezzel összefüggésben, az óriási informatikai és számítástechnikai fejlődés kedvező táptalajt nyújt a „homo sedens”, az egy helyben ülő embertípus kialakulásához (Hamar et al. 2010).

A 2011. évi CXC. törvény a nemzeti köznevelésrốl 27. §-a 11-13. bekezdése értelmében, felmenő rendszerben be kellett vezetni a heti öt testnevelésórát az általános és középiskolákban. A törvény mindennapos testneveléssel összefüggő „betúje” már a kezdetektől ellentmondásosnak bizonyult. Ennek alátámasztására példaként hozható fel a heti öt testnevelésóra kettébontása, azaz a heti két tanóra kiválthatósága, az ehhez kapcsolódó „igazolási mizéria”, valamint a szakos tanár ellátottság anomáliája, amely a tantárgy tanítását nem szaktanárok kezébe is helyezi.

Trencsényi László (2016) az iskolai testnevelés és sport, valamint a testnevelő tanárok helyzetérôl tár elénk „elfogult, de szakmai érvelésre törő oktatásügyi körképet”. Az egészséges fiatal nemzedék nevelése szempontjából problematikusnak tartja a tankötelezettség törvénybe foglalt leszállítását, mondván: „,...azok az ifjúsági csoportok, melyek anyagi okok, különböző veszélyeztetettség okán ebben az életkorban kisodródnak az oktatási rendszerből, súlyosan veszélyeztetve vannak nem csupán "ép lel- 
kük", de "ép testüket“ illetően is" (Trencsényi 2016: 11). A szerző kételyeit fejezi ki, hogy a mindennapos testnevelés elő́rása betartható-e ilyen infrastrukturális háttérrel. Nehezményezi az „egy tanterves” tartalmi szabályozást is, amely szerinte jelentősen csökkenti az iskolák adaptivitását, ezért (is) a helyi tantervekben alig van mód helyi változatok megfogalmazására, például egy hegyvidéki vagy egy vízparti iskola sajátos szükségleteinek kielégítésére. A hosszú délutánig kötelező iskolai benntartózkodás előírása fékezi a testnevelő tanárok településük tömegsportéletében való részvételének lehetőségét.

A testnevelés tantárgy és a testnevelő tanárok vonatkozásában nehézségek nemzetközi szinten is léteznek. Ken Hardman és Joe Marshall munkáikban a problémák között sorolják fel többek között a testnevelés tantárgy negatív szakmai megítélését, valamint a hiányos létesítmény- és felszerelésellátottságot. Ugyanakkor Európában, az Európai Parlament 2007. évi határozatát követően, jelentős elốrelépés történt a testnevelés területén. A határozat ugyanis arra hívta fel a tagállamok figyelmét, hogy egyrészt elemezzék országuk iskolai testnevelésének helyzetét, különös tekintettel a gyerekek egészségi állapotának tükrében. Másrészt - a felmerülő társadalmi igény hatására - a közoktatás minden fokán vezessék be a heti legalább három kötelező testnevelésórát (Hardman \& Marshall 2005; 2009; Hardman 2011).

\section{Kérdésfeltevések és hipotézisek}

Kérdésfeltevéseink és hipotéziseink aktualitását egyrészt a testnevelés köznevelésben (korábban közoktatásban) betöltött funkciójának megváltozása, másrészt az a tény adja, hogy a 2012/13. tanév kezdetétôl fokozatosan bevezetésre került a heti öt testnevelésóra. Ebben a tanulmányban olyan témákban feltett kérdésekre keresünk válaszokat, mint a testnevelés státusza a többi tantárgyhoz, illetve a testnevelő tanárok helyzete a többi tanárhoz viszonyítva.

H1 - Feltételezésünk szerint - annak ellenére, hogy a mindennapos testnevelés bevezetése felértékelte a tantárgy iskolában betöltött szerepét - a vizsgálatban részt vevők azon álláspontra helyezkednek, hogy a tárgy megitélése nem éri el a többiét.

H2 - Emellett azt is feltételeztük, hogy a megkérdezettek a testnevelő tanárok helyzetét hasonlónak vagy inkább alacsonyabbnak ítélik meg, mint a kollégáikét.

Kérdést fogalmaztunk meg azzal kapcsolatban is, hogy léteznek-e olyan központi intézkedések, amelyek az átmenetet biztosítják a kötelező testnevelés és az iskolán kívüli sportolás között.

H3 - Feltételezésünk szerint az a több évtizedes hiátus, ami az iskolai testnevelés és az iskolán kívüli sportolás közötti átmenetet jellemezte, még mindig tetten érhető. Ezen utóbbi kérdésfeltevésnél - igenlő válasz esetén, nyílt végű kérdés formájában - a vizsgálati személyektől példákat is kértünk a szerintük legfontosabb intézkedésekre.

H4 - Feltételezésként fogalmazódott még meg, hogy a megkérdezettek véleményalkotása a nem, az életkor, az iskolai végzettség, a lakóhely és a tanár/tanító iskolatípusa alapján is jellemzően nyilvánul meg. 


\section{Anyag és módszer}

\section{Vizsgált személyek}

Annak érdekében, hogy a kérdéseinkre adott válaszok megfelelően reprezentálják az ország egész területén testnevelést oktató pedagógusok véleményét, a csoportos (kiválasztott iskolákban testnevelést oktató összes pedagógus) rétegzett mintavételi eljárást választottuk (magyarországi régiók: 1-7; fenntartó: állami, egyházi, egyéb; iskolatípus: általános iskola, gimnázium, szakiskola; iskola nagysága: kis és nagy iskola). A rendelkezésünkre álló, az ország területén található összes feladatellátási helyet és az ott tanuló diákok számát tartalmazó listából becsült alapsokaságot 17500 főben határoztuk meg. Az alapsokaság az összes tanuló, az ellátandó testnevelésórák, illetve az egy tanár által oktatott órák száma alapján került becslésre. A válaszadásra felkértek tervezett mintanagyságát 1200 fóben állapítottuk meg. A rendelkezésre álló feladatellátási helyeket tartalmazó listából 312 iskola került kiválasztásra. Az iskolákba kiküldött kérdőíveket 1114 testnevelést oktató pedagógus töltötte ki, mely válaszok 293 iskolából érkeztek. A visszautasító iskolák helyett - a mintavételi elvek betartása mellett - a tervezett arányok megtartása érdekében, további 19 iskola került kiválasztásra. A pótlólagosan kiválasztott iskolákban további 47 kérdőívet töltöttek ki, így a feldolgozásra került kérdőívek száma összesen 1161 ( $\mathrm{N}=1161$ ). A feltett kérdéseinkre kapott válaszokat a vizsgált személyek neme, életkora és iskolai végzettsége, valamint az alapján elemeztük, hogy a pedagógus hol, milyen településen (Budapesten, megyeszékhelyen, városban, községben), illetve milyen iskolatípusban (általános iskola 1-4. osztályban, általános iskola 5-8. osztályban, gimnáziumban, szakközépiskolában/ szakképző iskolában) tanít. A vizsgált személyek adatainak eloszlását az 1. táblázatban összegezzük:

1. táblázat. A vizsgált személyek adatainak eloszlása (fő/\%)

\begin{tabular}{|c|c|c|c|c|c|c|c|c|c|c|}
\hline \multicolumn{11}{|c|}{$\mathrm{N}=1161(100)$} \\
\hline Nem & \multicolumn{5}{|c|}{ Férfi: $470(40,5)$} & \multicolumn{5}{|c|}{ Nő: $691(59,5)$} \\
\hline Életkor & \multicolumn{2}{|c|}{$\begin{array}{l}30 \text { év alatt: } \\
90(7,7)\end{array}$} & \multicolumn{3}{|c|}{$\begin{array}{l}\text { 31-45 év: } \\
465(40,1)\end{array}$} & \multicolumn{4}{|c|}{$\begin{array}{l}\text { 46-60 év: } \\
583(50,2)\end{array}$} & $\begin{array}{l}60 \text { év felett: } \\
23(2,0)\end{array}$ \\
\hline $\begin{array}{l}\text { Iskolai } \\
\text { végzettség }\end{array}$ & $\begin{array}{c}\text { Hagyomá- } \\
\text { nyos } \\
\text { egyetemi: } \\
455(39,2)\end{array}$ & \multicolumn{2}{|c|}{$\begin{array}{c}\text { Bolognai } \\
\text { rendszerú: } \\
52(4,5)\end{array}$} & \multicolumn{2}{|c|}{$\begin{array}{c}\text { Tanárkép- } \\
\text { ző főiskola: } \\
316(27,2)\end{array}$} & $\begin{array}{l}\text { Tan } \\
\text { kép } \\
305\end{array}$ & $\begin{array}{l}\text { ító- } \\
\text { ző: } \\
26,3)\end{array}$ & \multicolumn{2}{|c|}{$\begin{array}{l}\text { Tanítóképző } \\
\text { és más: } \\
27(2,3)\end{array}$} & $\begin{array}{l}\text { Tanár- } \\
\text { képző } \\
\text { és más: } \\
6(0,5)\end{array}$ \\
\hline Hol tanít? & \multicolumn{2}{|c|}{$\begin{array}{l}\text { Budapesten: } \\
216(18,6)\end{array}$} & \multicolumn{3}{|c|}{$\begin{array}{c}\text { Megyeszékhelyen: } \\
343(29,5)\end{array}$} & \multicolumn{3}{|c|}{$\begin{array}{l}\text { Városban: } \\
429(37,0)\end{array}$} & \multicolumn{2}{|c|}{$\begin{array}{l}\text { Községben: } \\
173(14,9)\end{array}$} \\
\hline $\begin{array}{l}\text { Iskolatí- } \\
\text { pus }\end{array}$ & $\begin{array}{c}\text { Ált. isk. } \\
1-4 . \\
\text { osztály: } \\
279 \\
(24,0)\end{array}$ & $\begin{array}{r}\text { Ált } \\
5 \\
\text { osz } \\
204\end{array}$ & & $\begin{array}{c}\text { Gimná- } \\
\text { zium: } \\
202(17,4)\end{array}$ & $\begin{array}{l}\text { Sz: } \\
\text { zép } \\
\text { ké } \\
229\end{array}$ & $\begin{array}{l}\text { kkö- } \\
\text { szak- } \\
\text { oző: } \\
(19,7)\end{array}$ & $\begin{array}{r}\text { Ált. } \\
1- \\
\text { oszt } \\
189(\end{array}$ & & $\begin{array}{c}\text { Ált. isk./ } \\
\text { középis- } \\
\text { kola: } \\
41(3,5)\end{array}$ & $\begin{array}{c}\text { Gimnázi- } \\
\text { um/szak- } \\
\text { iskola: } 17 \\
(1,5)\end{array}$ \\
\hline
\end{tabular}


A táblázat adatainak értelmezéséhez magyarázatként hozzátesszük, hogy az iskolai végzettség sorban található „Tanítóképző és más” kifejezés azokat a vizsgálati személyeket gyüjti egy csoportba, akik a tanítóképző főiskola mellett elvégeztek még vagy egy hagyományos (bolognai rendszerű képzés előtti) egyetemi, vagy egy bolognai rendszerű, vagy pedig egy tanárképző főiskolai képzést. A „Tanárképző és más” kifejezés azokat a vizsgálati személyeket jelenti, akik a tanárképző főiskola mellett elvégeztek vagy egy hagyományos egyetemi, vagy egy bolognai rendszerű képzést. A milyen iskolatípusban tanít (iskolatípus) sorban az iskolák szerkezetétől, évfolyamaik számától függően is többféle válaszalternatíva létezett, ezért kellett itt is összevont csoportokat létrehoznunk (példaként lásd a sor hatodik celláját, ahol az általános isk./középiskola címszó magában foglalja az általános iskola 1-4. és 5-8. osztályát, valamint a gimnáziumot, a szakközépiskolát és/vagy szakképző iskolát is, illetve a hetedik cellában a szakiskola kifejezés egyben a szakközépiskolát és a szakképző iskolát is jelenti).

\section{A vizsgálat módszere}

A keresztmetszeti vizsgálat módszere kérdőíves felmérés volt. A felhasznált kérdőív két korábbi vizsgálat kérdőívének az ötvözete. Egyrészt a 2000-2008 közötti időszakban elvégzett, illetve publikált, Testnevelő tanári vélemények a rendszerváltást követő tantervi változásokról című (Hamar \& Derzsy 2002; Hamar et al. 2006; Hamar et al. 2008), másrészt az International Survey of the State and Status of School Physical Education című, Ken Hardman és Joe Marshall (Hardman 2009; Hardman \& Marshall 2009; Hardman 2011) által végzett, illetve közzétett vizsgálaté. A felsorolt szakanyagok - a tudományos és szakmai eredmények publikálása mellett - az általunk használt kérdőív megbízhatóságát is igazolják. Mivel a kérdőívekben szereplő kérdések önállóan is értelmezhetőek, ezért a vizsgálatunk témájának megfelelő kérdések kerültek be a pedagógusok számára kiküldött kérdőívünkbe. Az angol nyelvről fordítást, valamint a szakmai és nyelvi ellenőrzést (a visszafordítást) két anyanyelvű szaklektor végezte. Az adatfelvételre a 2013/14. tanévben került sor. A kérdőívek kitöltése minden esetben az iskolaigazgatók jóváhagyásával történt.

\section{Adatfeldolgozás}

Az alapstatisztikai adatok (gyakoriságok) megadása mellett, a nominális változók illeszkedés és függetlenség vizsgálatára a Pearson-féle Khi-négyzet-próbát alkalmaztuk. Azokban az esetekben, ahol a cellák ötnél kisebb elemszámot tartalmaztak, a Fisher exact tesztet használtuk. A szignifikanciaszintet $\mathrm{p}<0,05$-ben határoztuk meg. 


\section{Eredmények}

Az első kérdés két (igen-nem), míg a második és a harmadik három (magasabbhasonló-alacsonyabb) válaszalternatívát kínált. Azzal tisztában vagyunk, hogy az ezen a „szúk keresztmetszeten” át kapott válaszok önmagukban nem kellóen informatívak. Ugyanakkor a vizsgálatban ekképpen nyert adatok - természetesen a teljesség igénye nélkül - utalhatnak olyan tendenciákra, amelyek közelebb vihetnek a testnevelés tantárgy és a testnevelő tanárok helyzetének alaposabb megismeréséhez.

- Ön szerint a testnevelésnek ugyanaz a státusza (megitélése), mint a többi tantárgynak? - kérdésre adott válaszok eredményei.

A kérdésre 1160 vizsgálati személy válaszolt. A megkérdezett pedagógusok közül összességében csak 419-en $(36,1 \%)$ gondolják úgy, hogy a testnevelésnek ugyanaz a státusza (megítélése), mint a többi tantárgynak, 741-en (63,9\%) viszont ellenkező előjelû választ adtak. Ennél a kérdésnél a Pearson-féle Khi-négyzet-próba, az igen-nem válaszok arányát vizsgálva, az életkori csoportok mint független változó tekintetében mutatott szignifikáns hatást $\left(\chi^{2}=11,99 ; \mathrm{p}<0,01\right)$. A részletes adatokat a 2 . táblázat szemlélteti:

2. táblázat. Az életkorok szerinti adatok az 1. kérdés válaszainál (fö/\%)

\begin{tabular}{|l|r|r|r|}
\hline \multicolumn{1}{|c|}{ Életkori csoport } & Igen & Nem & Összesen \\
\hline 30 év alatt & $24(26,7)$ & $66(73,3)$ & $90(100)$ \\
\hline $31-45$ év között & $149(32,1)$ & $315(67,9)$ & $464(100)$ \\
\hline $46-60$ év között & $237(40,7)$ & $346(59,3)$ & $583(100)$ \\
\hline 60 év felett & $9(39,1)$ & $14(60,9)$ & $23(100)$ \\
\hline Összesen & $419(36,1)$ & $741(63,9)$ & $1160(100)$ \\
\hline
\end{tabular}

A számadatokból az látszik, hogy a fiatalabb pedagógusok (a 45 év alattiak) kevesebb igenlő választ adtak, mint az idősebbek (a 46 év felettiek). Sokatmondó, hogy az igenlő válaszok százalékos adatai az életkor előrehaladtával - egészen a 60 év feletti korosztályig - folyamatosan emelkedő $(26,7 \rightarrow 32,1 \rightarrow 40,7)$, míg a nemleges válaszoké csökkenő $(73,3 \rightarrow 67,9 \rightarrow 59,3)$ értékeket mutatnak.

- Milyen a testnevelés helyzete a többi tantárggyal (például: nyelvórák, matematika stb.) összehasonlitva? - kérdésre adott válaszok eredményei.

A kérdésre 1161 vizsgálati személy válaszolt. A megkérdezett kollégák közül öszszességében csak 95-en (8,2\%) gondolják úgy, hogy a testnevelés helyzete magasabb státuszú, mint a többi tantárgyé, míg 413-an (35,6\%) hasonlónak, 653-an (56,2\%) pedig alacsonyabbnak ítélik meg. Ennél a kérdésnél egyik vizsgált csoport (nem, életkor, iskolai végzettség, a munkavégzés települése, illetve iskolatípusa) esetében sem találtunk szignifikáns eltérést.

Az első két kérdés eredményeit összegezve azt állapíthatjuk meg, hogy a Pearsonféle Khi-négyzet-próba csak egy esetben adott szignifikáns eltérést, mégpedig az első kérdés életkori csoportjainak összehasonlításában. Itt a válaszokból az derül ki, hogy 
legkevésbé a 30 év alatti pedagógusok gondolják úgy, hogy a testnevelésnek ugyanaz a státusza (megítélése), mint a többi tantárgynak. A válaszadói trendet követve az rajzolódik ki, hogy az életkor előrehaladtával ez a vélemény fokozatosan megváltozik.

A vélhető - s a szerzők szubjektív véleményét sem nélkülöző - magyarázat a fiatalok és az idősebbek eredendően eltérő világképében (átalakult értékpreferenciáiban), valamint abban keresendő, hogy a rendszerváltozást követően az iskolai testnevelés helye, szerepe és tartalmi vonatkozásai az oktatáspolitika és az oktatásirányítás szintjén, illetve a tantestületeken belül is gyökeresen megváltoztak. Erre még jobban rásegített a mindennapos testnevelés bevezetése. A fiatalabb kollégák már ebben a megváltozott közegben ítélik meg a tantárgyuk státuszát, míg a nagyobb tapasztalattal rendelkező idősebbeknél még élhetnek nosztalgikus emlékek.

- Ön szerint Magyarországon milyen a testneveló tanárok helyzete a többi tanárboz viszonyitva? - kérdésre adott válaszok eredményei.

A kérdésre 1161 értékelhető válasz érkezett. A megkérdezett kollégák közül öszszességében csak 164-en (14,1\%) gondolják úgy, hogy a testnevelő tanárok helyzete a többi tanárhoz viszonyítva magasabb státuszú. 691-en (59,5\%) hasonlónak, míg 306-an (26,4\%) alacsonyabbnak ítélik meg.

Ennél a kérdésnél a Pearson-féle Khi-négyzet-próba, a vizsgált változók között, az iskolai végzettséget tekintve szignifikáns eltérést mutatott $\left(\chi^{2}=36,12 ; p<0,001\right)$. A részletes adatokat a 3 . táblázat szemlélteti:

3. táblázat. Az iskolai végzettségek szerinti adatok a 3. kérdés válaszainál (fó/\%)

\begin{tabular}{|l|c|c|c|c|}
\hline \multicolumn{1}{|c|}{ Iskolai végzettség } & Magasabb & Hasonló & Alacsonyabb & Összesen \\
\hline $\begin{array}{l}\text { Hagyományos } \\
\text { egyetemi }\end{array}$ & $66(14,5)$ & $241(53,0)$ & $148(32,5)$ & $455(100)$ \\
\hline Bolognai rendszerú & $7(13,5)$ & $30(57,7)$ & $15(28,8)$ & $52(100)$ \\
\hline $\begin{array}{l}\text { Tanárképző } \\
\text { főiskola }\end{array}$ & $36(11,4)$ & $197(62,3)$ & $83(26,3)$ & $316(100)$ \\
\hline Tanítóképző & $53(17,4)$ & $199(65,2)$ & $53(17,4)$ & $305(100)$ \\
\hline Tanítóképző és más & $2(7,4)$ & $22(81,5)$ & $3(11,1)$ & $27(100)$ \\
\hline Tanárképző és más & $0(0)$ & $2(33,3)$ & $4(66,7)$ & $6(100)$ \\
\hline Összesen & $164(14,1)$ & $691(59,5)$ & $306(26,4)$ & $1161(100)$ \\
\hline
\end{tabular}

Az iskolai végzettségnél a legfigyelemreméltóbb adat, hogy a hagyományos egyetemi tanárképzésben végzettek 32,5\%-a (148 fö) véli alacsonyabb szintűnek a testnevelő tanárok helyzetét a többi tanárhoz viszonyítva. A testnevelők magasabb státuszát legnagyobb mértékben a tanítóképző főiskolát végzett kollégák preferálják 17,4\% (53 fő).

A kérdésre adott válaszok arányait vizsgálva a Hol tanít? mint független változó vonatkozásában is szignifikáns eltérést kaptunk $\left(\chi^{2}=26,07 ; \mathrm{p}<0,001\right)$. A részletes adatokat a 4. táblázat szemlélteti: 
4. táblázat. A munkavégzés települései szerinti adatok a 3. kérdés válaszainál (fő/\%)

\begin{tabular}{|l|r|c|c|c|}
\hline \multicolumn{1}{|c|}{ Hol tanít? } & Magasabb & Hasonló & Alacsonyabb & Összesen \\
\hline Budapesten & $25(11,6)$ & $124(57,4)$ & $67(31,0)$ & $216(100)$ \\
\hline Megyeszékhelyen & $66(19,2)$ & $188(54,9)$ & $89(25,9)$ & $343(100)$ \\
\hline Városban & $40(9,3)$ & $271(63,2)$ & $118(27,5)$ & $429(100)$ \\
\hline Községben & $33(19,1)$ & $108(62,4)$ & $32(18,5)$ & $173(100)$ \\
\hline Összesen & $164(14,1)$ & $691(59,5)$ & $306(26,4)$ & $1161(100)$ \\
\hline
\end{tabular}

A településeknél a legszembetűnőbb adat a városban oktatók „magasabb státuszú” válaszának 9,3\%-os (40 fő) szerény mértéke. Kiemelendő még a Budapesten tanító pedagógusok, testnevelő tanárok helyzetét alacsonyabbnak véleményező 31\%-os (67 fő), azaz az átlagtól felfelé, illetve ugyanezen oszlopban, a községben dolgozók 18,5\%os (32 fő), azaz az átlagtól jelentősen lefelé eltérő értéke.

E kérdésnél egy harmadik összehasonlítási szempont alapján is szignifikáns eltérést kaptunk $\left(\chi^{2}=45,33 ; p<0,001\right)$, nevezetesen a Milyen iskolatípusban tanít? kérdésre kialakított kategóriák tekintetében. A részletes adatokat az 5. táblázat szemlélteti:

5. táblázat. Az iskolatípusok szerinti adatok a 3. kérdés válaszainál (fő/\%)

\begin{tabular}{|l|r|r|r|r|}
\hline \multicolumn{1}{|c|}{ Iskolatípus } & Magasabb & Hasonló & Alacsonyabb & Összesen \\
\hline Ált. isk. 1-4. & $48(17,2)$ & $189(67,7)$ & $42(15,1)$ & $279(100)$ \\
\hline Ált. isk. 5-8. & $30(14,7)$ & $114(55,9)$ & $60(29,4)$ & $204(100)$ \\
\hline Gimnázium & $23(11,4)$ & $102(50,5)$ & $77(38,1)$ & $202(100)$ \\
\hline $\begin{array}{l}\text { Szakközép/ } \\
\text { szakképző }\end{array}$ & $40(17,5)$ & $124(54,1)$ & $65(28,4)$ & $229(100)$ \\
\hline Ált. isk. 1-8. & $18(9,5)$ & $122(64,6)$ & $49(25,9)$ & $189(100)$ \\
\hline $\begin{array}{l}\text { Ált. isk./ } \\
\text { középisk. }\end{array}$ & $5(12,2)$ & $28(68,3)$ & $8(19,5)$ & $41(100)$ \\
\hline Gimn./szakisk. & 0 & $12(70,6)$ & $5(29,4)$ & $17(100)$ \\
\hline Összesen & $164(14,1)$ & $691(59,5)$ & $306(26,4)$ & $1161(100)$ \\
\hline
\end{tabular}

$\mathrm{Az}$ iskolatípusok szerinti elemzés is azt mutatja, hogy a válaszadók legnagyobb része a „hasonló” választ preferálja. A hét válaszalternatívából adódóan az egyes kategóriák (cellák) adatai nagy szóródást mutatnak (példaként hozható fel, hogy az egyik cellában nulla szám található).

Magyarországon a pedagógusok helyzete évtizedek óta napirenden lévő téma (lásd erkölcsi és anyagi megbecsülés kérdése). A testnevelést oktatók számos esetben eltérő módon vélekednek saját magyarországi helyzetükről, példának okáért az iskolai végzettségük alapján is. A 3. táblázat adatai azt tükrözik, hogy - az utolsó két kategóriát az alacsony elemszám miatt nem figyelembe véve - a tanítóképző főiskolát végzettek összességében jóval alacsonyabbnak ítélik meg a testnevelő tanárok többi tanárhoz 
viszonyított helyzetét, mint az egyetemi vagy a főiskolai tanárképzést befejezők. Ennek evidencia számba menő magyarázata egyrészt az eltérő felsőoktatási képzésben, másrészt a tanárok, illetve tanítók eltérő pedagógiai státuszában rejlik.

A Hol tanít? - milyen nagyságú településen - kérdés válaszainál (lásd 4. táblázat) jelentkező szignifikáns eltérésekre a legkézenfekvőbb magyarázat a pedagógusok szocioökonómiai státusza (társadalmi-gazdasági helyzete) lehet. Ma Magyarországon nem ugyanazon társadalmi, gazdasági, helyenként politikai közegben dolgoznak a pedagógusok. Mások az infrastrukturális s az anyagi juttatásbeli elvárások is. A testnevelést oktatóknak Budapesten vagy egy nagyobb településen más feladatokkal kell megbirkózniuk, mint egy községben. Kisebb településeken jobban érvényre jut a jó értelemben vett lokálpatriotizmus. Feladatként gyakorta nemcsak az iskolai, hanem az egész település sportéletének koordinálása is jelentkezik. Ezért (is) gondolhatják úgy a községekben testnevelést oktató kollégák, hogy az ő helyzetük a többi tanárhoz viszonyítva kevésbé alacsony.

Az iskolatípus szerinti szignifikáns eltérésekre is magyarázatul szolgálhat az eltérő felsőoktatási képzés, valamint a tanárok és tanítók különböző pedagógiai státusza. Egészen más megítélés alá eshet a testnevelők többi tanárhoz képest viszonyított helyzete aszerint, hogy a válaszadó pedagógus az alsó tagozatos, többnyire nevelő, vagy a gimnáziumi, arányaiban inkább oktató tevékenység részese.

- Léteznek-e olyan központi intézkedések, amelyek biztositják az átmenetet a kötelezó testnevelés és az iskolán kivüli sportolás között? (Ha IGEN-nel VÁLASZOLT, irjon példát a legfontosabb intézkedésekre) - kérdésre adott válaszok eredményei.

A kérdésre 1129 vizsgálatban részt vevő személy válaszolt. A megkérdezett kollégák közül összességében 461-en (40,8\%) gondolják úgy, hogy léteznek olyan központi intézkedések, amelyek biztosítják az átmenetet a kötelező testnevelés és az iskolán kívüli sportolás között. 668-an (59,2\%) viszont ellenkező előjelű választ adtak.

Az igenlő 461 fő közül 326-an (70,7\%) válaszoltak a nyílt végü - a legfontosabb intézkedésekre példát író - kérdésre is. A válaszokból nyolc kategóriát képeztünk, melyeket a 6. táblázat szemlélteti:

6. táblázat. A 4. kérdés nyílt végû válaszaiból kialakított kategóriák és eredményeik (fő/\%)

\begin{tabular}{|l|c|}
\hline \multicolumn{1}{|c|}{ Válaszok } & $\begin{array}{c}\text { A válaszok elöfordulásának gyakorisága } \\
\text { és százalékos értékek }\end{array}$ \\
\hline $\begin{array}{l}\text { - A plusz két testnevelésóra kiváltható az iskolán } \\
\text { kívüli sportolással, és az ilyen értelemben megfo- } \\
\text { galmazott válaszok. }\end{array}$ & $137(42,1)$ \\
\hline $\begin{array}{l}\text { - A Bozsik-program, a Kölyökatlétika és a „Dobd a } \\
\text { kosárba” programok. }\end{array}$ & $30(9,2)$ \\
\hline $\begin{array}{l}\text { - A különböző sportolási formák (edzés, akadé- } \\
\text { miák, úszás, labdarúgás, kézilabda stb.) nagyobb } \\
\text { térnyerése. }\end{array}$ & $66(20,2)$ \\
\hline - A mindennapos testnevelés bevezetése által meg- \\
nyíló lehetőségek (például tehetségkutatás).
\end{tabular}




\begin{tabular}{|c|c|}
\hline Válaszok & $\begin{array}{c}\text { A válaszok előfordulásának gyakorisága } \\
\text { és százalékos értékek }\end{array}$ \\
\hline $\begin{array}{c}\text { • A tömegsport és sportköri foglalkozások, a diák- } \\
\text { olimpiai, DSE- és ISK-versenyek, s az így kiala- } \\
\text { kuló tehetséggondozás. }\end{array}$ & $58(17,8)$ \\
\hline $\begin{array}{l}\text { - Szélesebb körú pályázati lehetőségek, tornaterem- } \\
\text { építési projektek. }\end{array}$ & $4(1,2)$ \\
\hline $\begin{array}{l}\text { - Az „átmenet” - a kiemelt szerep következtében- } \\
\text { testnevelö-pedagógus, illetve szülöi háttér függő. }\end{array}$ & $3(0,9)$ \\
\hline $\begin{array}{l}\text { - A közoktatási típusú sportiskolák, a legújabb } \\
\text { (köznevelési) törvények, rendeletek és szabályok. }\end{array}$ & $16(4,9)$ \\
\hline Összesen & $326(100)$ \\
\hline
\end{tabular}

A nyolc kategória közül kettőben kaptunk szignifikáns eltérést, mégpedig a Hol tanít? és a Milyen iskolatípusban tanít? csoportoknál $\left(\chi^{2}=32,40, \mathrm{p}<0,05\right.$; illetve $\left.\chi^{2}=73,03, \mathrm{p}<0,001\right)$.

A Hol tanít? kérdés alapján adott válaszok eloszlását a 7. táblázat mutatja be:

7. táblázat. A munkavégzés települései szerinti adatok a 4. kérdés nyílt végü válaszainál (fö/\%)

\begin{tabular}{|l|c|c|c|c|c|c|c|c|c|}
\hline $\begin{array}{l}\text { Hol tanít?/ } \\
\text { Kategóriák } \\
\text { sorszámai }\end{array}$ & $\mathbf{1}$ & $\mathbf{2}$ & $\mathbf{3}$ & $\mathbf{4}$ & $\mathbf{5}$ & $\mathbf{6}$ & $\mathbf{7}$ & $\mathbf{8}$ & Összesen \\
\hline Budapesten & $\begin{array}{c}22 \\
(34,9)\end{array}$ & $\begin{array}{c}7 \\
(11,1)\end{array}$ & $\begin{array}{c}16 \\
(25,4)\end{array}$ & $\begin{array}{c}2 \\
(3,2)\end{array}$ & $\begin{array}{c}13 \\
(20,6)\end{array}$ & $\begin{array}{c}2 \\
(3,2)\end{array}$ & 0 & $\begin{array}{c}1 \\
(1,6)\end{array}$ & $63(100)$ \\
\hline $\begin{array}{l}\text { Megye- } \\
\text { székhelyen }\end{array}$ & $\begin{array}{c}40 \\
(51,4)\end{array}$ & $\begin{array}{c}3 \\
(3,8)\end{array}$ & $\begin{array}{c}10 \\
(12,8)\end{array}$ & $\begin{array}{c}6 \\
(7,7)\end{array}$ & $\begin{array}{c}15 \\
(19,2)\end{array}$ & 0 & 0 & $\begin{array}{c}4 \\
(5,1)\end{array}$ & $78(100)$ \\
\hline Városban & $\begin{array}{c}61 \\
(45,2)\end{array}$ & $\begin{array}{c}11 \\
(8,1)\end{array}$ & $\begin{array}{c}25 \\
(18,5)\end{array}$ & $\begin{array}{c}4 \\
(3,0)\end{array}$ & $\begin{array}{c}19 \\
(14,1)\end{array}$ & $\begin{array}{c}2 \\
(1,5)\end{array}$ & $\begin{array}{c}3 \\
(2,2)\end{array}$ & $\begin{array}{c}10 \\
(7,4)\end{array}$ & $135(100)$ \\
\hline Községben & $\begin{array}{c}14 \\
(28,0)\end{array}$ & $\begin{array}{c}9 \\
(18,0)\end{array}$ & $\begin{array}{c}15 \\
(30,0)\end{array}$ & 0 & $\begin{array}{c}11 \\
(22,0)\end{array}$ & 0 & 0 & $\begin{array}{c}1 \\
(2,0)\end{array}$ & $50(100)$ \\
\hline Összesen & $\begin{array}{c}137 \\
(42,1)\end{array}$ & $\begin{array}{c}30 \\
(9,2)\end{array}$ & $\begin{array}{c}66 \\
(20,2)\end{array}$ & $\begin{array}{c}12 \\
(3,7)\end{array}$ & $\begin{array}{c}58 \\
(17,8)\end{array}$ & $\begin{array}{c}7 \\
(1,2)\end{array}$ & $\begin{array}{c}3 \\
(0,9)\end{array}$ & $\begin{array}{c}16 \\
(4,9)\end{array}$ & $326(100)$ \\
\hline
\end{tabular}

A településeknél kiemelendő adat, hogy „A plusz két testnevelésóra kiváltható” kategóriát leginkább a megyeszékhelyeken $(51,4 \%)$ és városokban $(45,2 \%)$ lakók preferálják.

Az iskolatípusok alapján adott válaszok eloszlását a 8. táblázat mutatja be:

8. táblázat. Az iskolatípusok szerinti adatok a 4. kérdés nyílt végú válaszainál (fő/\%)

\begin{tabular}{|l|c|c|c|c|c|c|c|c|c|}
\hline $\begin{array}{l}\text { Iskolatípus/ } \\
\text { Kategóriák } \\
\text { sorszámai }\end{array}$ & $\mathbf{1}$ & $\mathbf{2}$ & $\mathbf{3}$ & $\mathbf{4}$ & $\mathbf{5}$ & $\mathbf{6}$ & $\mathbf{7}$ & $\mathbf{8}$ & Összesen \\
\hline $\begin{array}{l}\text { Ált. isk. } \\
1-4 .\end{array}$ & $\begin{array}{c}36 \\
(46,7)\end{array}$ & $\begin{array}{c}8 \\
(10,4)\end{array}$ & $\begin{array}{c}19 \\
(24,7)\end{array}$ & $\begin{array}{c}2 \\
(2,6)\end{array}$ & $\begin{array}{c}8 \\
(10,4)\end{array}$ & 0 & $\begin{array}{c}1 \\
(1,3)\end{array}$ & $\begin{array}{c}3 \\
(3,9)\end{array}$ & $77(100)$ \\
\hline $\begin{array}{l}\text { Ált. isk. } \\
\text { 5-8. }\end{array}$ & $\begin{array}{c}27 \\
(37,0)\end{array}$ & $7(9,6)$ & $\begin{array}{c}15 \\
(20,5)\end{array}$ & $1(1,4)$ & $\begin{array}{c}14 \\
(19,2)\end{array}$ & $1(1,4)$ & $2(2,7)$ & $6(8,2)$ & $73(100)$ \\
\hline
\end{tabular}




\begin{tabular}{|c|c|c|c|c|c|c|c|c|c|}
\hline $\begin{array}{l}\text { Iskolatípus/ } \\
\text { Kategóriák } \\
\text { sorszámai }\end{array}$ & 1 & 2 & 3 & 4 & 5 & 6 & 7 & 8 & Összesen \\
\hline $\begin{array}{l}\text { Gimná- } \\
\text { zium }\end{array}$ & $\begin{array}{c}30 \\
(55,5)\end{array}$ & $\begin{array}{c}2 \\
(3,7)\end{array}$ & $\begin{array}{c}10 \\
(18,5)\end{array}$ & $\begin{array}{c}4 \\
(7,4)\end{array}$ & $\begin{array}{c}7 \\
(13,0)\end{array}$ & 0 & 0 & $\begin{array}{c}1 \\
(1,9)\end{array}$ & $54(100)$ \\
\hline $\begin{array}{l}\text { Szakközép/ } \\
\text { szakképző }\end{array}$ & $\begin{array}{c}28 \\
(53,9) \\
\end{array}$ & $\begin{array}{c}1 \\
(1,9)\end{array}$ & $\begin{array}{c}7 \\
(13,5) \\
\end{array}$ & $\begin{array}{c}2 \\
(3,8) \\
\end{array}$ & $\begin{array}{c}11 \\
(21,2) \\
\end{array}$ & $\begin{array}{c}1 \\
(1,9)\end{array}$ & 0 & $\begin{array}{c}2 \\
(3,8) \\
\end{array}$ & $52(100)$ \\
\hline $\begin{array}{l}\text { Ált. isk. } \\
1-8 .\end{array}$ & $\begin{array}{c}9 \\
(17,1) \\
\end{array}$ & $\begin{array}{c}12 \\
(22,6)\end{array}$ & $\begin{array}{c}13 \\
(24,5)\end{array}$ & $\begin{array}{c}1 \\
(1,9) \\
\end{array}$ & $\begin{array}{c}14 \\
(26,4)\end{array}$ & 0 & 0 & $\begin{array}{c}4 \\
(7,5) \\
\end{array}$ & $53(100)$ \\
\hline $\begin{array}{l}\text { Ált. isk./ } \\
\text { középisk. }\end{array}$ & $\begin{array}{c}1 \\
(10,0)\end{array}$ & 0 & $\begin{array}{c}2 \\
(20,0)\end{array}$ & $\begin{array}{c}1 \\
(10,0)\end{array}$ & $\begin{array}{c}4 \\
(40,0)\end{array}$ & $\begin{array}{c}2 \\
(20,0)\end{array}$ & 0 & 0 & $10(100)$ \\
\hline $\begin{array}{l}\text { Gimn./ } \\
\text { szakisk. }\end{array}$ & $\begin{array}{c}6 \\
(85,7)\end{array}$ & 0 & 0 & $\begin{array}{c}1 \\
(14,3)\end{array}$ & 0 & 0 & 0 & 0 & $7(100)$ \\
\hline Összesen & $\begin{array}{c}137 \\
(42,1)\end{array}$ & $\begin{array}{c}30 \\
(9,2)\end{array}$ & $\begin{array}{c}66 \\
(20,2)\end{array}$ & $\begin{array}{c}12 \\
(3,7)\end{array}$ & $\begin{array}{c}58 \\
(17,8)\end{array}$ & $\begin{array}{c}4 \\
(1,2)\end{array}$ & $\begin{array}{c}3 \\
(0,9)\end{array}$ & $\begin{array}{c}16 \\
(4,9)\end{array}$ & $326(100)$ \\
\hline
\end{tabular}

A Milyen iskolatípusban tanít? kérdésnél két kiugró adat található: a gimnáziumban és a szakközép/szakképző iskolában tanítók, első kategóriába tartozó válaszainak 55,5 és 53,9\%-os értékei.

Ennél a kérdésnél a két szignifikáns eltérésre magyarázatul ugyanazok a tényezők is szolgálhatnak, amelyeket az Ön szerint Magyarországon milyen a testnevelő tanárok helyzete a többi tanárhoz viszonyítva? kérdésnél említettünk. A nyílt végű válaszok esetében magyarázat lehet még a mindennapos testnevelés bevezetése. Ez az intézkedés egyaránt kihat a különböző sportolási formák (edzés, akadémiák, úszás, labdarúgás, kézilabda stb.) nagyobb térnyerésére, valamint a tömegsport és sportköri foglalkozások, a diákolimpiai, DSE- és ISK-versenyekre, s az így kialakuló tehetséggondozásra. A leginkább fókuszált terület azonban a délutáni plusz két testnevelésóra iskolán kívüli sportolással történő kiváltása. A heti öt testnevelés(óra) bevezetése tehát amennyire örömteli, annyi gondot is okozó (lásd még infrastrukturális és/vagy foglalkoztatáspolitikai problémákat).

\section{Összefoglalás}

Vizsgálati eredményeinket összegezve megállapíthatjuk, a vizsgált személyek azon álláspontra helyezkedtek, hogy a testnevelés tantárgy státusza nem éri el a többi tárgyét. Ezzel első hipotézisünk beigazolódott. A megkérdezettek a testnevelő tanárok többi tanárhoz viszonyított helyzetét viszont nagyrészt hasonlónak ítélik meg. Második hipotézisünk így csak részben igazolódott be. A válaszokban szerepet játszhat a testnevelők tantestületben elfoglalt státusza, anyagi és erkölcsi megbecsülése, de a testnevelés tantárgy rangja is. Ugyanakkor elgondolkodtató, hogy a mindennapos testnevelés bevezetésének időszakában a testnevelést oktatók több mint egynegyede $(26,4 \%)$ gondolja úgy, hogy a testnevelő tanárok helyzete rosszabb, mint a többi tanáré. 
Első magyarázatként az életkori különbségek (idősödő pedagógusi kar) adódnak, de itt nem találtunk szignifikáns eltérést. Ami viszont vizsgálati eredményeinkből látszik, hogy az ekképpen véleményt formálók elsősorban a magasabban képzett, egyetemet végzettek köréből kerülnek ki. Az evidens eredmény magyarázata abban keresendő, hogy az egyetemet, túlnyomórészt Testnevelési Egyetemet végzetteknek másképpen okoz gondot a személyi, tárgyi feltételek alacsony szintje, az oktatáselméleti és módszertani problémák köre, mint a tanítói végzettséggel rendelkezőknek.

A vizsgáltak körének nagyobb része látja úgy, hogy a kötelező testnevelés és az iskolán kívüli sportolás közötti átmenet még mindig nem kielégítő. A harmadik hipotézisünk így beigazolódott. E feltett kérdéssel kapcsolatban (is) vissza-visszatérő téma a mindennapos testnevelés bevezetése. Meglátásunk szerint a heti öt testnevelési foglalkozás bevezetése számos oknál fogva indokolt, ugyanakkor megkerülhetetlen az a tény, hogy megfelelő infrastruktúra nélkül az iskolai testnevelés nem (sem) képes prosperálni.

Negyedikként azt feltételeztük, hogy a megkérdezettek véleményalkotása a nem, az életkor, az iskolai végzettség, a lakóhely és a tanár/tanító iskolatípusa alapján is jellemzően nyilvánul meg. E csoportok között egy olyan található, amelyik egyetlen vizsgált kérdésnél sem mutatott szignifikáns eltérést, az a nem. A megvizsgált témákban tehát férfiak és nők véleményalkotása között nincs különbség. Ekképpen a negyedik hipotézisünk csak részben igazolódott be.

E tanulmányból is kivilágló számos oknál fogva a testnevelés kérdése még jó ideig a figyelem homlokterében lesz, nemcsak a pedagógusoknál, hanem például a tantervkészítôknél (lásd a kezdődő újabb NAT-munkálatokat), de talán nem túlzás, ha azt mondjuk, a közvélemény teljes egészénél is. A mindennapos testnevelés ügyét meg kell védenünk a manapság terjedő „emiatt túlterhelt a gyerek az iskolában” fals nézettől. Viszont, miközben a testnevelés ügyét szolgáló oktatáspolitikai és oktatásirányítási döntéseket hozunk (hoznak), nem szabad szem elôl téveszteni Ballér Endre sok-sok hasznos gondolatának egyikét, miszerint: „....minden szabadság a sokszor korlátokat is jelentő összefüggések determináló hatásait felismerve és tekintetbe véve érvényesülhet. Különösen így van ez egy olyan bonyolult, hierarchikus rendszer esetében, mint a közoktatás" (Ballér 2004: 93).

\section{Hivatkozott irodalom}

- Ballér E. (1996). Tantervelméletek Magyarországon a XIX-XX. században. A tantervelmélet forrásai, 17. kötet. Budapest, Országos Közoktatási Intézet.

- Ballér E. (2004). A tantervelmélet uitjain. Válogatás négy évtized pedagógiai írásaiból. Budapest, Aula Kiadó Kft.

- Gergely Gy. (2002). A testnevelés tantárgy helyzete és fejlesztési feladatai. Ujj Pedagógiai Szemle, 52 (7-8), 161-174. 
- Gergely Gy. (2007). Kórdokumentum - Testnevelés és sport múveltségterület a NAT 2003-ban. Fejlesztó Pedagógia, 18 (1), 39-42.

- Hamar P. \& Derzsy B. (2002). Testnevelő tanári vélemények aktuális tantervelméleti kérdésekról. Magyar Pedagógia, 102 (2), 145-157.

- Hamar P., Leibinger É., Derzsy B. \& Ozsváth K. (2006). Testnevelő tanári vélemények a rendszerváltást követô tantervi változásokról. Kalokagathia, 44 (3-4), 81-97.

- Hamar P., Munkácsi I., Leibinger É. \& Soós I. (2008). Physical Education teacher's views on curriculum development tendencies in Hungary following the political transition. Journal of Physical Education and Sport Science by the Coimbra Network, 4, 41-49.

- Hamar, P., Biddle, S., Soós, I., Takács, B. \& Huszár, Á. (2010). The prevalence of sedentary behaviours and physical activity in Hungarian youth. European Journal of Public Health, 20 (1), 85-90.

- Hardman, K. \& Marshall, J. (2005). Physical Education in Schools in European Context: Charter Principles, Promises and Implementation Realities. In Green, K. \& Hardman, K. (eds.): Physical Education. Essential Issues (pp. 39-64). London, A SAGE Publications Company.

- Hardman, K. \& Marshall, J. (2009). Second World-wide Survey of School Physical Education. Final Report. Berlin, H \& P Druck, ICSSPE.

- Hardman, K. (2009). Selected Issues, Challenges and Resolutions in Physical Education. In Bokan, B. (Ed.): Theoretical, methodology and methodical aspects of physical education (pp. 11-20). Belgrade, University of Belgrade, Faculty of Sport and Physical Education.

- Hardman, K. (2011).W(h)ither Physical Education? The Future Ain't what it used to be! In Kovač, M., Jurak, G. \& Starc, G. (Eds.): $5^{\text {th }}$ International Congress, Youth Sport 2010 - „Knowledge for Sport”(pp. 47-57). Ljubljana, Faculty of Sport, University of Ljubljana.

- Kovács K. (2015). A sportolás mint támogató faktor a felsőoktatásban. Debrecen, CHERD-H.

- Trencsényi L. (2016). Elfogult, bár szakmai érvelésre törő oktatásügyi körkép 2016. In A mindennapos testnevelés az elméletben és a gyakorlatban (konferencia-programfüzet, pp. 11-12). Budapest, MTA PTB Szomatikus-nevelési Albizottság, Magyar Sporttudományi Társaság, Testnevelési Egyetem.

\section{Dokumentum}

- 2011. évi CXC. törvény a nemzeti köznevelésról. Magyar Közlöny, 2011. 162. szám, 39622-39695. 


\title{
Fintor GÁbor
}

\section{Tanulói nézetek a mindennapos testnevelésről észak-alföldi általános iskolákban}

\begin{abstract}
Absztrakt
Hazánkban, az iskolai testnevelésre vonatkozóan jelentős oktatáspolitikai változás történt a mindennapos testnevelés bevezetésével. Így a testnevelés és sport műveltségi terület változásainak vizsgálata adja kutatásunk központi témáját. Egyfelól a testnevelés tantárgy kedveltségét vizsgáltuk. Másfelől a NAT 2012 céljaihoz igazodva arra kerestük a választ, hogy a mindennapos testnevelésórával összefüggő pozitív és negatív attitűdök milyen értékkel jelennek meg a tanulók körében az Észak-Alföld régióban ( $\mathrm{n}=1074)$.

Az eredmények azt mutatják, hogy a tanulók igen kiemelkedő része (95\%) szereti a testnevelésórákat. A nemek közti kedveltség tekintetében azonban szignifikáns eltérés mutatható ki a fiúk javára $(\mathrm{p}=0,000)$. A testnevelők szerepe, motiváló hatása kiemelten jelentkezik kutatásunkban.
\end{abstract}

\section{Bevezetés, a téma relevanciája és elméleti háttere}

Tanulmányunk elméleti alapját az implementációs kutatások (Fazekas \& Halász 2012) és a tantervelméleti kérdések vizsgálatai jelentik (Hamar \& Petrovic 2008; Hardman \& Marshall 2009; Hamar 2012; Rétsági 2014; Rétsági \& Csányi 2014).

Az implementációkutatások arra keresik a választ, hogy a célokat miképpen lehet elérni, nem pedig arra, hogy mi is az adott cél. Nem magával a döntéssel foglalkoznak, hanem a folyamatot vizsgálják. Ha a közoktatást célzó beavatkozások érintett szereplőiről vagy érdekcsoportjairól (actors, agents, stakeholders) ejtünk szót, az iskola belső szereplőire (vezetők, pedagógusok, egyéb munkatársak), az iskolahasználókra (szülők, diákok), továbbá a fejlesztést irányítókra (kormányzati adminisztráció, helyi irányítók) kell gondolnunk. Idesorolhatók még azok az oktatási ágazaton belüli fejlesztést támogató szervezetek képviselői (pedagógiai szolgáltatók, tanácsadók), akik jelentős hatással lehetnek a beavatkozások megvalósítására. Ha az implementáció szintjeit is vizsgáljuk, akkor megállapítható, hogy a makroszintet a társadalom átfogó szintje jelöli (jelen esetben az egészségtudatosság szerepe az oktatási folyamatokban), míg a mikroszintet az egyének (vagyis diákok, pedagógusok). Az ezeken a szinteken történő folyamatok határozzák meg az implementáció sikerességét (Fazekas \& Halász 2012). 
Tanulmányunk elméleti részének másik vizsgálati alapját a tantervelméleti kérdések adják. 1995. október 5-én a kormány elfogadta az első Nemzeti alaptantervet, ami azóta többször is változott. Több kutató (Rétsági et al. 2011; 2014; Hamar \& Derzsy 2002a; 2002b; Hamar 2012) elemezte a közoktatási, nemzeti köznevelési törvény változásai mentén a Nemzeti alaptanterveket (1995 - NAT1, 2003 - NAT2, 2007 - NAT3, 2012 - NAT4), ezzel rávilágítottak a testnevelés és sport múveltségterület tartalmi módosulásaira. A legújabb Nemzeti alaptantervet a kormány 110/2012. (VI. 4.) Korm. rendelete alapján 2012. június 4-én fogadták el. Benne konkrét nevelési célként jelenik meg a testi-lelki egészségre nevelés. Az oktatáspolitikai szemléletváltás a testnevelés és sport mưveltségi területre döntően kedvező hatással volt, elsősorban a mindennapos testnevelés bevezetése miatt. A törvény 27 . §-a kötelezően elő́rija a nappali rendszerú oktatásban a mindennapos testnevelés megszervezését, azaz a heti öt testnevelésóra megtartását. A 2012/2013-as tanévtól az 1., az 5. és a 9. évfolyamon, majd felmenő rendszerben minden évfolyamon kötelező a mindennapos testnevelés megtartása. A 2015/2016-os tanévtől kezdve teljessé vált a mindennapos testnevelés bevezetése. Meghatározásra került az is, hogy a tanulónak legyen igénye a helyes táplálkozásra, a mozgásra, az egészséges életmódot jelentő életvitelre. Az alapelvek és célok megvalósításához szükséges a jártasság a játék- és sportkultúrában, illetve lényeges az igény az egészséges, egészségközpontú tevékenységrendszer kialakítására. A műveltségi területnek, ezen belül az iskolai testnevelésnek kiemelt céljai vannak: a sportági ismeret, a mozgáskészségek fejlesztése, bővitése, részvétel a szabadidős és sportversenyeken, a rendszeres fizikai aktivitás és az egészséges életvitellel kapcsolatos értékrend kialakítása. Összességében a négy NAT célrendszerét elemezve megállapítható, hogy minden esetben azon követendő általános értékekből, elvekből (kulcskompetenciákból) indul ki, melyek az egész dokumentumot átszövik, s ezek rendszerben történő érvényesítése a fố szempont. Az egészségre nevelés területén a testnevelés mindig is kiemelt szerepet játszott. Ugyanakkor a mindennapos testnevelés bevezetésével a tantárgy új dimenzióba került, új minőséget hozhat létre, hiszen a megfogalmazott célok képessé tehetik a múveltségi területet tanítókat a hatékonyabb egészségnevelésre, az egészségkultúra alapjainak megteremtésére (Rétsági 2014). A 2012-es NAT szerint a testnevelés müveltségterület kiemelt célja, hogy a rendszeres fizikai aktivitás minden tanuló életében komoly szerepet kapjon, hogy a tanulókat élethosszig tartó, egészségtudatos, aktív életvezetésre szocializálja (Makszin 2014).

\section{A kutatások tükrében}

Hazánkban 1867 óta szerepel az iskolai oktatási rendszerben a testnevelés. A mindennapos testnevelés gondolata már a XX. század fordulóján (1900-as évek) megjelent, azonban bevezetésére példákat csak az 1980-as években látunk. A század elején, az 1910-es években már sürgették a mindennapos testnevelés bevezetését. 1925-tól Kmetykó János, a Testnevelési Főiskola igazgatója harcolt érte. 1933-ban Hóman Bá- 
lint vallás- és közoktatásügyi miniszter öt fôvvárosi iskolában rendelte el a bevezetését. A 80-as években vezettek be csak több helyen az országban (Ivanics 1993), pedig a három Csongrád megyei iskolában a „mindennaposok” ügyesebbek lettek, figyelemkoncentrációjuk, reakcióidejük javult (Szegfü 1989). Szegeden a tanulók lelkesen fogadták az új lehetőséget, igényükké vált a rendszeres testmozgás (Udvarhelyi 1989). Kecskeméten a tanulók megszerették a mindennapos testnevelést, javult fizikai teljesítőképességük (Grosán 2001), ugyanakkor Hódmezővásárhelyen csak részben bizonyították azt, hogy a rendszer hozzájárul az egészség és fittség javitásához. A szubjektív szempontok azonban egyértelmủen a program eredményességét mutatják, hisz a gyermekek többségének mozgástudatosságára motiválóan hat. Nem sikerült bizonyítani, hogy a rendszeres testmozgással kialakul a napi szintű sportolási igény szükségessége (Tózsa-Rigóné Németh 2011), azonban a heti öt testnevelésóra hozzájárul a tanulók fizikai teljesítőképességének emelkedéséhez (Vári et al. 2012).

Magyarország egyedülálló Európában a heti öt iskolai testneveléssel. Így nemzetközi szinten néhány olyan fontos kutatást igyekszünk bemutatni, mely a napi szintü sportolás jótékony hatásait tárja elénk. Pennsylvania államban a bevezetett mindennapos testnevelést kontrollcsoport bevonásával vizsgálták. Ez az aktív sportprogram sikeresnek bizonyult. Akik részt vettek a mindennapos testnevelésben összességében mindenben fejlődtek (egészségileg, mozgásügyességben) azon iskolák diákjaihoz viszonyítva, ahol nincs mindennapi testnevelésóra (Erfle 2014). Shephard és Trudeau (2013) Franciaországban longitudinális vizsgálattal világítottak rá, hogy amikor a rendszeresen sportoló tanulók felnőttek lettek, a gyermekkori napi szintủ sportolás pozitív hatással volt a sporthoz való hozzáállásukra. Barnett és mtsai. (2008) is megerősítik, hogy a gyermekkorban szerzett értékek nagyban meghatározzák a felnőttkori életvitelt. Egy horvátországi tanulmány azt bizonyítja, hogy a gyermekek napi szintú mozgása fejleszti a gimnasztikai készségek elsajátítását (Culjak et al. 2014). Egy görög reprezentatív kutatásban 2043 gyermeket (9-13 éves korig) vizsgáltak, amit 77 általános iskola közremúködésével végeztek. Kimutatták, hogy a rendszeres mozgás és a napi ötszöri megfelelő táplálkozás hozzájárul a pozitív egészségmagatartás mintázatainak kialakulásához, illetve rögzüléséhez (Moschonis et al. 2013).

Borbély (2014) országos reprezentatív kutatásában megállapítja, hogy a mindennapos testnevelés bevezetésének szükségességével a megkérdezett lakosság több mint 70\%-a ért egyet, vagyis a felnőtt lakosság (potenciálisan a szülők) is szükségét érezte a mindennapos testnevelés bevezetésének.

Rétsági (2015) szerint a mindennapos testnevelés egyre nagyobb lehetőségeket teremt, és a sport általi szocializációban a tanórai testnevelés játssza a főszerepet. Többek között Mikulán (2013) is azt fejti ki tanulmányában, hogy hosszú távon a mindennapos testnevelés kedvező hatást válthat ki. Így meglátásunk szerint lényeges annak vizsgálata, hogy mit gondolnak a tanulók a tantárgyról. 


\section{A tantárgy kedveltsége és fontossága}

Bakonyi (1969a; 1969b; 1969c) vizsgálatában arra kereste a választ, hogy a tanulók szeretik-e a testnevelést, és hány órát szeretnének a testnevelésből. A nemek tekintetében nem talált lényeges eltérést. Ugyanakkor az általános iskolások nagyobb arányban szerettek volna több testnevelésórát, mint a középiskolások. Biróné (2004) vizsgálatai szerint a kedvenc tantárgyak közé sorolható a testnevelés. Báthory (1997) is kifejti, hogy az általános iskolai tanulók körében a testnevelés kedveltség tekintetében kiemelkedik a többi tantárgy közül, ugyanakkor hozzáteszi, hogy ez az életkor előrehaladtával csökken, illetve a fiúknál előkelőbb helyen szerepel, mint a lányoknál. Ezt megerősíti Hamar (2012) vizsgálata is, melyben erdélyi és magyarországi tanulókat hasonlítottak össze a 2006/2007-es tanévben.

Hamar és Karsai (2008) keresztmetszeti elrendezésben vizsgálta a 11-18 éves diákok $(\mathrm{N}=2840)$ testneveléshez kötődő affektivitását. Ez alapján a fiúk elfogadóbb hozzáállást, beállítódást mutatnak, mint a lányok, továbbá a pozitív érzelmi telítettség elsősorban a lányok körében nagymértékben csökken az életkor előrehaladtával. A testnevelő tanár is attitúdformáló szerepet játszik az iskolában. A tantárgy tanítása, tanulása során kialakult pozitív érzelmek nemcsak a testnevelésben, hanem a nevelési, oktatási folyamat teljes egészében is növelhetik a pedagógiai hatékonyságot. Az életkor emelkedésével párhuzamosan csökkenő kedveltségre is rámutattak. A heti két testnevelésben részt vevők véleménye kedvezőtlenebb az óraszámmal kapcsolatban, mint a heti négyórás testnevelésben szereplőéké. Azonban ha az összes tanulót vizsgáljuk, azt látjuk, hogy 77,8\%-uk szeretne négy vagy annál is több testnevelésórát egy héten. Ezzel kijelenthető, hogy a tanulók kedvező véleménnyel vannak a testnevelésről.

Egy másik, 8. osztályosok életmódjával, testi nevelésével kapcsolatos véleményükkel foglalkozó reprezentatív felmérés eredményei szerint a válaszadóknak kevesebb mint fele szerette csak a testnevelésórákat. Az ellenszenv fő okaként a testnevelésórák tartalmát jelölték meg, ezt követte a tanár személye, majd a részvétel fárasztó jellege (Rétsági \& Ács 2010).

Saját korábbi longitudinális vizsgálatunkban feltártuk három Szabolcs-SzatmárBereg megyei kisvárosi általános iskolában tanuló 6. évfolyamos diákok $(\mathrm{N}=131)$ testnevelés iránti attitűdjének változását egy év elteltével. A testnevelésórák fontosságának megítélésében a két mérés között a diákoknál a kereszttábla-elemzés kapcsán szignifikáns eltérést nem tapasztaltunk. Azonban 52,7\% mást állít 2014-ben, mint az előző évben. A legnagyobb mértékben ugyanolyan fontosnak itélik meg a testnevelés helyzetét, mint egyéb más tantárgyét. Ha azokat vizsgáljuk, akik mást állítottak a két méréskor, megfigyelhető, hogy a „nem összehasonlítható más tantárggyal” állítások száma csökkent a legnagyobb mértékben (1/4-re). 75\%-uk már azt állítja, hogy a testnevelés ugyanolyan fontos, mint más tantárgy, és $16,7 \%$ itéli meg fontosabb tantárgyként. Azok, akik az első mérés alkalmával kevésbé fontosnak ítélték meg a tantárgyat, $71,4 \%$ szerint ugyanolyan fontossá vált, mint más tantárgy, és 14,3\% szerint fontosabb lett. Megállapítható, hogy a tantárgy megőrizte stabilitását, a testnevelésórák fontos- 
ságának megítélése nem csökkent a vizsgálatunk szerint egy év elteltével sem, vagyis amióta mindennapos testnevelésben vesznek részt a minta alanyai (Fintor 2014, Fintor-Szabó 2013).

\section{Célkitüzések, hipotézisek}

Tanulmányunkban az általános iskolások mindennapos testneveléshez füződő viszonyait elemezzük. A szakirodalom alapján a kutatók bizakodóak, kedvező képet várnak a mindennapos testnevelés bevezetésétől (NAT 2012; Mikulán 2013; Rétsági 2015), továbbá a korábbi tapasztalatok is pozitív képet mutatnak (az 1980-as évek tapasztalatai; Tózsa-Rigóné Németh 2011). Nemzetközi viszonylatban a szakirodalom alapján megállapítható, hogy sehol nincs mindennapos testnevelés Magyarországon kívül. Azonban a napi szintű sportolás jótékony hatásaira vonatkozóan számos nemzetközi vizsgálati eredmény született, néhányat bemutattunk, s ezek alapján a rendszeres fizikai aktivitást összhangba állíthatjuk a mindennapos testneveléssel (Shephard \& Trudeau 2013; Moschonis et al. 2013; Culjak et al. 2014).

Vizsgálatunkban, melyet saját készítésû Likert-skálás kérdőív segítségével végeztünk, a kérdőív azon kérdéscsoportjára adott válaszokat elemeztük, amelyek a diákok véleményét mutatja a mindennapos testnevelésórák NAT-ban is meghatározott céljaival, feladataival kapcsolatban. Ez a kérdéscsoport 28 állítást tartalmazott, melyeknél egy 1-4-ig terjedő skálán az egyet- és egyet nem értésüket kellett kifejezniük a tanulóknak (1 - egyáltalán nem igaz, 2 - inkább nem igaz, 3 - inkább igaz, 4 - teljes mértékben igaz).

\section{Hipotézisek}

- Feltételezzük, hogy a megkérdezettek jelentős többsége pozitívan nyilatkozik a testnevelés tantárgyról, ugyanakkor a nemek között szignifikáns különbséget várunk e tekintetben a fiúk javára (H1).

- Feltételezzük, hogy a mindennapos testnevelés bevezetéséhez kapcsolódó állításokból kialakított csoportok esetében a nemek és a testnevelés tantárgy kedveltségénél is különbségek lesznek kimutathatóak (H2).

\section{Anyag és módszerek}

Kutatásunkban az implementáció szereplői közül a diákok nézetei kerülnek tárgyalásra. A vizsgálatunkba bevont minta elemszáma 1153 fó, mely a nemek tekintetében egyenletes eloszlást mutat, a válaszadók 45,3\%-a fiú, 52,2\%-a pedig lány. A minta $15 \%$-a nem sportol, 17,5\%-a hetente egyszer, 19,3\%-a hetente kétszer, 48,0\%-a pedig legalább hetente háromszor. ${ }^{1}$

1 A megkérdezettektől azt kértük, hogy a sportolás alatt olyan mozgásra gondoljanak, ami legalább 30 percig tart, s válaszaikat a kötelező (mindennapos) testnevelésórán kívül értve jelöljék. 
Vizsgálatunkban a sportolási szintet az iskolai, a hobbi, a versenyszerủ/egyesületi keretek közé soroltuk. Így a sportolási szint esetében a minta 43,5\%-a hobbiszerúen sportol, iskolai szinten 17,4\%, egyesületi keretek között pedig 23,8\%. A mintában az évfolyamokból azonos arányban kerültek ki a diákok.

A kutatás mintavételi kerete az Észak-Alföld régióba tartozó három megye minden olyan intézményét jelentette, amely az általános iskola felső tagozatos osztályait iskolai képzésben foglalkoztatják. A minta az adott régióra megyei, településtípus-szintű és diákszám alapján reprezentatív mintának tekinthető. A mintavétel többlépcsős rétegzett minta. Az eredményekben a minta elemszámának változása az adott kérdésre történő válaszhiányok miatt változik.

\section{Eredmények}

Első hipotézisünk vizsgálatakor a diákok testnevelés tantárgy kedveltségére adott válaszait elemezzük (1. táblázat).

1. táblázat. A testnevelés tantárgy kedveltségének nemek szerinti megoszlása (\%) $(\mathrm{N}=1074)$

\begin{tabular}{|l|c|c|}
\hline \multirow{2}{*}{ Nagyon szeretem } & Fiú & Lány \\
\cline { 2 - 3 } & $56,4 \%$ & $36,2 \%$ \\
\hline Szeretem & $38,7 \%$ & $53,9 \%$ \\
\hline Nem szeretem & $2,0 \%$ & $8,1 \%$ \\
\hline Nagyon nem szeretem & $2,9 \%$ & $1,9 \%$ \\
\hline
\end{tabular}

Forrás: saját kutatás

Megállapítható, hogy a tantárgy elfogadása mindkét nem esetében magas, a testnevelés tantárgyat a diákok közel 95\%-a szereti vagy nagyon szereti. A nemek közti kedveltség esetében azonban szignifikáns eltérés mutatható ki $(p=0,000)$. A fiúk a nagyon szeretem kifejezést 56,4\%-os értékkel jelölték meg, míg a lányoknál ilyen magas értékben $(53,9 \%)$ a szeretem kategória jelent meg. A kedveltség ilyen jellegú nemek közti különbsége igazolja első hipotézisünket, vagyis azt, hogy a diákok esetében a fiúk testneveléshez való viszonya még mindig kiemelkedően jobb, mint a lányoké, nem változott a mindennapos testnevelés bevezetését követően, sem a szakirodalomhoz viszonyítva.

A következókben a kérdôivünk azon kérdéscsoportjának állításaira adott válaszait elemezzük, amelyek a mindennapos testnevelés bevezetéséhez és a NAT 2012-ben megfogalmazott célokhoz, feladatokhoz kapcsolódnak. Ez a kérdéscsoport 28 állítást tartalmazott (2. táblázat). 
2. táblázat. A mindennapos testnevelés bevezetéséhez kapcsolódó állítások átlagai $(\mathrm{N}=1153)$

\begin{tabular}{|c|c|}
\hline Mennyire igazak a következő állítások a testnevelésórákra a ti iskolátokban? & Átlag \\
\hline 1. A testnevelésórán csak egyfajta sportágat (pl.: kézilabdázás) gyakorolunk. & 1,52 \\
\hline 2. A testnevelö tanár szigorúbb, mint a többi tanár. & 1,88 \\
\hline 3. A testnevelő tanártól nehéz feladatokat kapunk. & 1,98 \\
\hline 4. A testnevelésóra miatt fáradt vagyok napközben. & 2,08 \\
\hline 5. A testnevelő tanárnak nagyok az elvárásai. & 2,16 \\
\hline $\begin{array}{l}\text { 6. A testnevelésórák miatt kedvelem a sportmúsorokat, sportközvetítéseket a televízióban, } \\
\text { az interneten. }\end{array}$ & 2,39 \\
\hline 7. A testnevelő tanártól hallottak miatt odafigyelek a táplálkozásra. & 2,42 \\
\hline 8. A testnevelő tanár az egészséges életmódról is szokott beszélni. & 2,68 \\
\hline 9. A testnevelésórák meghozzák a kedvemet ahhoz, hogy iskola után is sportoljak valamit. & 2,80 \\
\hline 10. A testnevelésórán változatos játékokat játszunk. & 2,86 \\
\hline $\begin{array}{l}\text { 11. A testnevelésórán rendszeresen kapunk értékelést (szóban értékel a tanár, piros pontot } \\
\text { ad, érdemjegyet ad stb.). }\end{array}$ & 2,88 \\
\hline 12. A testnevelésórán érdekes gimnasztikai gyakorlatokkal melegítünk be. & 2,89 \\
\hline 13. A testnevelésóra mindig bemelegítés, fő- és levezető részből áll. & 3,03 \\
\hline 14. A testnevelésóra végére jól elfáradok. & 3,05 \\
\hline 15. A testnevelésórákon megismerem a különböző sportágak versenyszabályait. & 3,07 \\
\hline 16. Sokat ügyesedtem, mert mindennap van testnevelésóránk. & 3,12 \\
\hline 17. A testnevelésórán rendszeresen játszunk. & 3,13 \\
\hline 18. A testnevelésóra megtanít a kudarc (vereség) elviselésére. & 3,14 \\
\hline 19. A testnevelésórán mindig jó a hangulat. & 3,15 \\
\hline 20. A testnevelő tanártól sokat hallunk a testedzés, a sportolás fontosságáról. & 3,17 \\
\hline 21. A testnevelésórán saját teljesítőképességemhez mérten értékelnek. & 3,19 \\
\hline 22. Jó kapcsolatom van a testnevelő tanárral. & 3,20 \\
\hline 23. A testnevelésórán többféle sportágat tanulunk. & 3,21 \\
\hline 24. A testnevelésóra megtanít a csapatban való együttmúködésre. & 3,21 \\
\hline 25. Úgy érzem, a testnevelésóráktól egészségesebb lehetek. & 3,23 \\
\hline 26. A testnevelés miatt kerülöm az olyan káros dolgokat, mint a dohányzás, alkoholfogyasztás. & 3,33 \\
\hline $\begin{array}{l}\text { 27. A testnevelő tanár azt szeretné, hogy mindenki megtanulja az adott anyagot, } \\
\text { ezért mindenkinek segít. }\end{array}$ & 3,35 \\
\hline 28. A testnevelésórán az is lehet sikeres, aki más órán rosszabbul teljesít. & 3,45 \\
\hline
\end{tabular}

Forrás: saját kutatás

Az állításokra adott válaszok átlagainak vizsgálatakor kiderült, hogy a diákok a legmagasabb átlaggal (legmagasabb egyetértéssel) azt az állítást jelölték meg, amely a testnevelő segítőkészségét mutatja az elsajátítandó tananyaggal kapcsolatban, illetve 
a saját teljesítményük sikerességére utal. Fontos eredmény, hogy ezt az órát olyannak tekintik, amelyben bárki lehet sikeres, még az is, aki más tantárgyból gyengébben teljesít. A legkisebb átlagot a több sportág megismerésére utaló állítás mutatta, amely azt igazolja, hogy a mindennapos testnevelésórák keretében a diákoknak valóban lehetőségük van többféle sportág megismerésére. Ezt támasztja alá az az eredmény is, amely a testnevelésórán többféle sportágat tanulunk állítás magas átlagértéke is mutat.

Mindezek után az állítások csoportosítására statisztikai program segítségével klaszteranalízist alkalmaztunk, olyan csoportok jöttek létre, amelyek esetében az állításoknál átfedések nem megengedettek.

Így három csoportot interpretáltunk.

1. csoport: 1., 9., 10., 12., 13., 15., 16., 17., 23., Tantárgyi ismeretek (átlag = 2,60)

2. csoport: 4., 6., 7., 14., 18., 19., 24., 25., 26., Egészségtudatosság (átlag = 2,88)

3. csoport: 2., 3., 5., 8., 11., 20., 21., 22., 27., 28., Testnevelő szerepe (átlag = 2,79)

Olyan csoportok jöttek létre, amelyekhez tartozó állítások a NAT 2012-ben is megfogalmazott célrendszerek köré is csoportosíthatók. Az első csoport esetében (Tantárgyi ismeretek) a testnevelésórák didaktikai és nevelési céljai jelennek meg. A második csoportba (Egészségtudatosság) a diákok egészséges életmódjához, személyiségfejlesztéséhez, egészségtudatosságához kapcsolódó állítások csoportosultak. A harmadik csoportban (Testnevelő szerepe) pedig a pedagógusszerep jelenik meg.

A csoportok esetében vizsgáltuk, hogy a nemek tekintetében találunk-e különbséget az átlagok vizsgálatánál. Megállapítható, hogy a kialakított csoportok esetében a diákok nemenkénti vizsgálatakor eltéréseket nem tapasztaltunk, egyetértés mutatkozik.

A kapott klasztercsoportok esetében a kedveltség szerinti megoszlás alapján kimutattunk szignifikáns különbséget $(\mathrm{p}=0,000)$ (3. táblázat).

3. táblázat. A klasztercsoportok és a testnevelés tantárgy kedveltségének megoszlása (\%) ( $\mathrm{N}$ = 933)

\begin{tabular}{|l|c|c|c|}
\hline & Tantárgyi ismeretek & Egészségtudatosság & Testnevelő szerepe \\
\hline Nagyon szeretem & $10,8 \%$ & $34,3 \%$ & $54,8 \%$ \\
\hline Szeretem & $31,7 \%$ & $40,5 \%$ & $27,8 \%$ \\
\hline Nem szeretem & $80,6 \%$ & $10,4 \%$ & $9,0 \%$ \\
\hline
\end{tabular}

Forrás: saját kutatás

Azok, akik nagyon szeretik a testnevelés tantárgyat, a legmagasabb értékkel a testnevelő szerepét jelölték meg (54,8\%). Valószínúleg a testnevelő befolyása jelenik meg náluk leginkább motiváló tényezôként a tantárgyi kedveltség tekintetében. Azok, akik „csak” szeretik a tantárgyat, náluk a leginkább az egészségtudatosság szerepe (40,5\%) emelkedik ki. Ôk ennek fontosságát érzik legerősebben célként a mindennapos test- 
nevelés bevezetését követően. Azok, akik nem szeretik az órákat, náluk a tantárgyi ismeretekre vonatkozó állítások jelennek meg magasabb átlaggal (80,6\%). Ők azok, akik leginkább kritikusai az órának, akiknek sok a tantárgyi ismeret, amit az órán kell elsajátítaniuk.

Megállapíthatjuk, hogy a második hipotézisünk csak részben igazolódott be, hiszen a nemek esetében nem, ugyanakkor a tantárgyi kedveltség esetében találunk eltérést a klasztercsoportok kialakítása után.

\section{Megbeszélés és következtetések}

A 2012 szeptemberétől felmenő rendszerben bevezetésre került mindennapos testnevelést követő negyedik évben végeztünk az Észak-Alföld régió felső tagozatos diákjai körében reprezentatív kutatást. A testnevelésórákkal összefüggő attitűdjeiket, az ott megjelenő NAT 2012 cél- és feladatrendszerének megjelenését vizsgáltuk. Ahogy Rétsági (2014) is fogalmaz, a mindennapos testnevelés bevezetésével a tantárgy új dimenzióba kerülhet, új minőséget hozhat létre, hiszen a megfogalmazott célok képessé tehetik a műveltségi területet tanítókat a hatékonyabb egészségnevelésre, az egészségkultúra alapjainak megteremtésére.

Eredményeink azt mutatják, hogy a nemek tekintetében a fiúknál a testnevelés tantárgy kedvelése jóval meghaladja a lányok ilyen arányú értékét, ez nem változott a korábbi kutatási eredményekhez képest. Azonban a tanulók igen kiemelkedő része (95\%) szereti a testnevelésórákat. Másrészt, az a feltételezésünk, hogy a nemek tekintetében a mindennapos testnevelés bevezetéséhez kapcsolódó állítások esetében végzett csoportosítás után szignifikáns különbséget találtunk, nem igazolódott be. A tantárgyi kedveltség esetében csoportok válaszaira adott átlagok tekintetében, azonban igen. Azok, akik nagyon szeretik a testnevelés tantárgyat, ook a testnevelők szerepét jelölték meg legmagasabb értékkel a válaszaik alapján.

Megállapítható, hogy vizsgálatunkban a testnevelők szerepe kiemelten jelenik meg a mindennapos testnevelés kapcsán, a pedagógusok továbbra is intézményi szerephordozó funkciója kimutatható a vizsgált intézményekben.

\section{Hivatkozott irodalom}

- Bakonyi F. (1969a). A testnevelés mennyiségének és minőségének befolyása a sportolási igény alakítására. A testnevelés tanitása, 5 (3), 75-78.

- Bakonyi F. (1969b). Az iskolai testnevelés hatása a tanulók testneveléssel és sporttal kapcsolatos szemléletére. A testnevelés tanitása, 5 (1), 19-30.

- Bakonyi F. (1969c). Szeretik-e a tanulók a testnevelést - hány órát szeretnének? A testnevelés tanitása, 5 (2), 35-38.

- Barnett, M.L., Morgan, J.P., van Beurden, E. \& Beard, R. J. (2008). Perceived sports competence mediates the relationship between childhood motor skill proficiency 
and adolescent physical activity and fitness: a longitudinal assessment. International Journal of Behavioral Nutrition and Physical Activity 5, 40. Forrás: http://www. ijbnpa.org/content/5/1/40/. Utolsó letöltés: 2015.06.20.

- Báthory Z. (1997). Tanulók, iskolák, különbségek. Egy differenciális tanitáselmélet vázlata. Budapest, Okker Kiadó.

- Biróné N. E. (2004). Sportpedagógia. Kézikönyv a testnevelés és a sport pedagógiai kérdéseinek tanulmányozásához. Budapest-Pécs, Dialóg Campus Kiadó.

- Borbély Sz. (2014). As parents see physical education (PE) from a representative survey's point of view. In Karlovitz J. T. (szerk.): Mozgás, környezet, egészség (pp. 39-54). Komarno, International Research Institue. Forrás: http://www.irisro.org/ health2014dec/14UrbinneBorbelySzilvia.pdf. Utolsó letöltés: 2015.06. 20.

- Culjak, Z., Miletic, D., Kalinski, S. Delas., K. \& Ana, Z. F. (2014). Fundamental Movement Skills Development under the Influence of a Gymnastics Program and Everyday Physical Activity in Seven-Year-Old Children. Iranian Journal of Pediatrics, 24 (2), 124-130.

- Erfle, S. (2014). Analyzing the Effects of Daily Physical Education in Middle Schools on Obesity: Evidence from Pennsylania's Active Schools Program. In Todao, R. (ed.): Handbook of Physical Education Research (pp. 91-109). New York, Nova Science Publishers. ISBN 978-1-63321-076-9.

- Fazekas Á. \& Halász G. (2012). Az implementáció világa. Az európai uniós forrásokból megvalósított magyarországi oktatásfejlesztési beavatkozások empirikus vizsgálatának elméleti megalapozása. Kézirat. Budapest, ELTE PPK Felsőoktatásmenedzsment Intézeti Központ. Forrás: http://www.impala.elte.hu/produktumoki-munkafazis. Utolsó letöltés: 2015.06. 08.

- Fintor G. (2014). Testmozgás a közösségben, avagy a mindennapos testnevelés jelenléte Szabolcs megyében. In. Juhász E. (szerk.): Közösségi Müvelódés - Közösségi Tanulás (pp. 67-79). Debrecen, Debreceni Egyetem TEK BTK Neveléstudományok Intézete.

- Fintor G. \& Szabó J. (2013). Correlations of Sport Levels and Popularity of Sport Programmes among Elementary School Students. Recreation, 4 (2), 11-16.

- Grosán P. (2001). Ízelítő a mindennapos testnevelés jegyében született iskolai programokból. Új Pedagógiai Szemle, 51 (11), 149-152.

- Hamar P. (2012). MindenNATos testnevelés. Új Pedagógiai Szemle, 62 (11-12), 87-97.

- Hamar P. \& Derzsy B. (2002a). Az elmúlt tíz esztendő tantervi változásainak tapasztalatai I. rész. Módszertani lapok. Testnevelés, 9 (1), 1-7.

- Hamar P. \& Derzsy B. (2002b). Az elmúlt tíz esztendő tantervi változásainak tapasztalatai II. rész. Módszertani lapok. Testnevelés, 9 (2), 1-6.

- Hamar P. \& Petrovic L. (2008). Physical education and education through sport in Hungary (Testnevelés és oktatás sport segítségével Magyarországon). In Klein, G. \& Hardman, K. (eds.): Physical Education and Sport Education in European Union (pp. 105-121). Paris, Editions Revue EPS, 11 avenue du Tremblay. 
- Hamar P. \& Karsai I. (2008). Az iskolai testnevelés affektív jellemzői 11-18 éves fiúk és lányok körében. Magyar Pedagógia, 108 (2), 135-147.

- Hardman, K. \& Marshall, J. (2009). Second World-wide Survey of School Physical Education. Final Report. Manchester, International Council of Sport Science and Physical Education, University of Manchester.

- Makszin I. (2014). A testnevelés elmélete és módszertana. Budapest-Pécs, Dialóg Campus Kiadó

- Mikulán R. (2013). Az iskolai testnevelés szerepe és jelentősége az egészségfejlesztésben. Új Pedagógiai Szemle, 63 (7-8), 48-69.

- Moschonis, G., Mavrogianni, C., Karatzi, K., Iatridi, V., Chrousos, P. George., L. \& Christos, Y. M. (2013). Increased physical activity combined with more eating occasions is beneficial against dyslipidemias in children. The Healthy Growth Study. Eur J Nutr, (52), 1135-1144.

- Rétsági E. (2014). Mindennapos testnevelés az iskolában. Élet és Tudomány, 69 (37), 1166-1167.

- Rétsági E. (2015). A sport szerepe a szocializációban és a pedagógiában. In Laczkó T. \& Rétsági E. (szerk.): A sport társadalmi aspektusai (pp. 51-61). Pécs, Pécsi Tudományegyetem Egészségtudományi Kar. ISBN 978-963-7178-72-6.

- Rétsági E. \& Ács P. (2010). A serdülők életmódja es testneveléssel kapcsolatos véleményük. Magyar Sporttudományi Szemle, 11 (44), 13-20.

- Rétsági E. \& Csányi T. (2014). Nemzeti alaptanterv 2012. Testnevelés és sport múveltségi terület - az iskolai testnevelés új kihívásai I. Magyar Sporttudományi Szemle, 15 (59), 32-37.

- Rétsági E., H. Ekler J., Nádori L., Woth P., Gáspár M., Gáldi G. \& Szegnerné Dancs H. (2011). Sportelméleti ismeretek. Budapest, Dialóg Campus.

- Shephard, J. R. \& Trudeau, F. (2013). Quality Daily Physical Education for the Primary School Student: A Personal Account of the Trois-Rivières Regional Project. Quest, 65 (1), 98-115.

- Tózsa-Rigóné Németh J. (2011). A mindennapos testnevelés komplex programja Hódmezövásárhelyen 2005-2009-ig: Megvalósulás, hatékonyságvizsgálat, szoftverfejlesztés. PhD-disszertáció. Szegedi Tudományegyetem, Neveléstudományi Doktori Iskola. Szeged. Forrás: http://doktori.bibl.u-szeged.hu/1488/1/ertekezes_ ekezetnelk.pdf. Utolsó letöltés: 2015. 06. 17.

- Vári B., Marton A. \& Balogh L. (2012). A mindennapos testnevelés hatásának követéses vizsgálata 1-4. osztályos tanulók körében. Magyar Sporttudományi Szemle, 14 (54), 59-60. 


\section{Forrásmunkák}

- Ivanics G. (1993). Mindennapos testnevelés. Fejlesztó pedagógia: pedagógiai szakfolyóirat, 4 (1-2), 11-13.

- NAT 2012. Új Pedagógiai Szemle, (1-3), 30-256.

- Szegfü I. (1989). Történeti áttekintés a mindennapos testedzésről. In Süli J. (szerk.): A mindennapos testedzés kézikönyve (pp. 2-6). Szeged, A Csongrád Megyei Tanács V. B. Művelődési Osztálya és Pedagógiai Intézete kiadványa.

- Udvarhelyi F. (1989). Ötletek és módszerek a mindennapos testgyakorlás megszervezéséhez. In Süli J. (szerk.): A mindennapos testedzés kézikönyve (pp. 40-63). Szeged, A Csongrád Megyei Tanács V. B. Művelődési Osztálya és Pedagógiai Intézete kiadványa. 


\title{
BAlogh LÁsZló, Kiss Mihály
}

\section{Merre tovább testnevelőtanár-képzés?}

\begin{abstract}
Absztrakt
A tanulmány célja, hogy bemutassa a testnevelőtanár-képzés céljait, a mindennapos testnevelés szakmai tartalmát, a jövőre vonatkozó instrukciókat. Ezzel, reményeink szerint, hozzájárulunk a testnevelés iránt érdeklődő, társ-tudományterületeket képviselő szakemberek kölcsönös együttműködéséhez.
\end{abstract}

\section{Bevezetés, avagy mi a baj (?) a testneveléssel}

A mindennapos testnevelés bevezetésével egyre nagyobb figyelem fordul az iskolai testnevelés felé. Kissé maliciózusan kérdezhetnénk, mi volt eddig, miért csak most. A testnevelő tanárok munkáját szívesen segítő szakemberek jelentek meg hirtelen egy iskolai tantárgy, pedagógiai végzettséget, testnevelő tanári diplomát igénylő területen.

Talán a heti öt alkalom adta valóban kiváló szakmai lehetőség, őszinte segítőkészség, talán egyéb indokok miatt, gyógytornászok (nem keverendő össze a pedagógus végzettségű gyógytestnevelővel, mint az gyakran előfordul), orvosok, pszichológusok, egyéb szakos tanárok stb. illették kritikával a testnevelés tantárgyat annak szakmai tartalma vagy éppen a testnevelő tanárok nem megfelelő képzettsége, felkészültsége miatt. Sőt nemegyszer merül fel napjainkban a mindennapos testnevelés szükségességének kérdése, a tanulók túlterheltségére hivatkozva.

Ugyanakkor, ahogyan azt a kedves olvasó később láthatja, a testnevelő tanárok alapvetően nyitottak az együttműködésre. Ez utóbbihoz azonban jelentős segítséget jelent, ha a kiinduláshoz a testnevelés tantárgyat, annak képzési és kimeneti követelményei, a képzésre való bejutás, a bemenet és a végzés, vagyis a kimenet követelményei is ismertekké válnak. Ez esetben - ahogyan az a tanulmánykötet címében is szerepel - nem merülhet fel kérdésként, hogy a testnevelés tantárgy valódi értékteremtö, és alapvetöen nem az élsportoló nevelése, hanem a természetes és sportági mozgásformák stb. feladat-, eszköz-és célrendszerével, felhasználásával a tanulók személyiségének formálása a fó cél!

Rövid tanulmányunk célja a testnevelőtanár-képzés jelenlegi rendszerének, szakmai tartalmának, jelenének és a mindenki számára egyaránt fontos jövőbeli szerepének rövid bemutatása.

A kérdés szakszerű áttekintését a szerzők szakmai kompetenciái garantálják.

Az első szerző a testnevelés szakfelelőseként, a fentiekben megjelölt bizottság elnökeként, különböző szakmai bizottságok tagjaként szerzett, valamint a testnevelés gyakorlatából nyert tapasztalatai adják a megbízható alapot a kérdés objektív vizsgálatához. 
Azért, hogy a testnevelés mindennapi gyakorlata, a valós élet alapos ismerete megfelelő súllyal legyen jelen a testnevelés és sport műveltségi terület bemutatásánál, erről második szerzőnk személye a biztosíték.

\section{Mi a testnevelés és sport múveltségi terület, és mi a célja?}

Elég gyakran keverednek olyan fogalmak, melyek egy nagy entitás részét képezik, de valójában annak jól körülhatárolható egységeit alkotják. Ahogy az orvostudományon belül gyógyít a kardiológus, a gasztroenterológus vagy éppen a traumatológus, mégsem keverhetjük össze a szerepeket, hiába egy tudományterület. Jelen esetben ugyan a mozgással kapcsolatos fogalom a testi nevelés, testnevelés, a testmozgás, testedzés, fizikai aktivitás, sport, rekreáció stb. is, de ezek nem rokon értelmú kifejezések, söt. Mivel a tanulmánykötet és ezen fejezet célja nem fogalommagyarázat, erre javasolunk számos igen kiváló testneveléselmélettel kapcsolatos szakkönyvet, csak a testnevelésre fogunk fókuszálni.

A testnevelés, vagy mint korábban nevezték, testgyakorlás, testgyakorlatok (íme, egy újabb, igaz korabeli elnevezés) több mint 200 éves múltra tekint vissza. Szerepelt, bár nem valósult meg, az 1777-es Ratio Educationisban, sőt olyan történelmi hírességek is kiálltak mellette, mint Széchenyi, Wesselényi vagy Kossuth.

Ha már történelem és debreceni kötödés: 1841-ben Péczely József debreceni pedagógus, akadémikus, az oktatási szerveknek tantervi indítványt tett, amelyben javasolta, hogy a gimnáziumokban „testgyakorló intézeteket” kell felállitani! (Báthori 1994)

Számos kiváló és egymással összhangban álló meghatározás tisztázza, mit értünk testnevelés alatt. Báthori (1994: 37) szerint „a testnevelés olyan céltudatos és tervszerűen irányított nevelési folyamat, amely sajátos mưvelődéstartalmával (mozgásos játékok, testgyakorlatok, sportági cselekvésrendszerek és az ezekhez tartozó elméleti ismeretek) a mindenoldalúan képzett személyiség kialakitására irányul, előre mutatóan meghatározott társadalmi célok alapján”.

Rétsági és H. Ekler szerint (2011) „nemcsak a közoktatásban jelen lévő iskolai tantárgyat (iskolai testnevelés) értjük testnevelés alatt, hanem az intézményesitett keretek között megvalósuló céltudatos, szakszerú és tervszerü testkulturális nevelö tevékenységeket (Biróné 1994). Tehát a testnevelést olyan gyüjtőfogalomként értelmezzük, amely magába foglalja az óvodában, a közoktatási intézményekben (alapfokú, középfokú oktatás), a felsóoktatásban, valamint a fegyveres testületekben folyó testnevelést is. A testnevelés elmélet ismeretei a testnevelés gyakorlatának felsorolt színterein azonos értékű és nélkülözhetetlen alapismereteknek számítanak. Mint ahogy azonos értékű és rendkívül fontos a különböző korosztályok testnevelését megvalósító szakpedagógiai tevékenység."

Ugyanitt H. Ekler (2011) szerint: ,a testnevelés szükebb értelmezésében egy tantárgy, sajátos nevelési-oktatási célokkal, müveltségtartalommal (gyakorlati és elméleti!), módszerekkel és eszközökkel. Speciális tartalma önálló kulturális érték, melynek elsa- 
játítása, sőt az elsajátítás színvonala életünk végéig befolyásolja az életminőségünket. Sajátos értékei és a személyiségre gyakorolt kiemelkedő hatásai révén hangsúlyos szerepet tölt be a testi nevelés feladatainak megoldásában."

Domokos (2013) szerint „a testnevelés tantárgy a testnevelés tudományra, a testnevelés és sportoktatás gyakorlatában felhalmozódott ismeretekre és a társadalmilag szükséges tevékenységekre támaszkodik. Az iskolai nevelés rendszerében olyan eszköz melynek segitségével a személyiség fejlödéséhez szükséges mozgásismereteket, jártasságot és készségeket sajátítanak el a tanulók. Formai jegyei megegyeznek a többi iskolai tantárgyéval, de az óraszám, ismeret és tevékenységtartalom sajátos megnyilvánulása a mozgásos tevékenységeken keresztül valósul meg. Sajátossága a többi iskolai tantárgytól ezért lényegesen eltér, hisz a műveltségtartalom elsajátításának nagy része aktív mozgásos tevékenység közben valósítható meg."

Azt gondoljuk, a fenti fogalmak, az éppen aktuális ideológiáktól függetlenül, egyöntetűen a testnevelés tantárgy értékteremtő szerepét, a testkultúra egyetemes kultúrához való tartozását és a személyiségformálásban betöltött rendkívüli szerepét emelik ki.

Miután röviden körüljártuk, mit értünk testnevelés alatt, tekintsük át, hogy mi alapján képezzük a testnevelő tanárokat. Ez a felsőoktatásban dolgozók számára nem jelent újdonságot, de sajnos különböző médiumokban a képzést illetően félreértések vannak.

\section{Mi alapján képezünk testnevelő tanárokat?}

A felsőoktatás szakjainak képzési rendjét a képzési és kimeneti követelmények (KKK) szabályozzák.

„Az adott szak képzési és kimeneti követelményei határozzák meg, hogy milyen alapképzési szakról milyen feltételek mellett lehet belépni a mesterképzési szakra, valamint hogy mely szakképzettség szerezhető az adott mesterképzésben, továbbá milyen személyi kompetenciák szükségesek a követelmények sikeres teljesítéséhez, a hallgató milyen szakmai ismeretekre tehet szert, illetve milyen nyelvvizsga szükséges az oklevél megszerzéséhez."

Ezt a testnevelö tanári szak esetében egy olyan szakértöi konzorcium állitotta össze, melyet a sporttudományképzést folytató intézmények szakemberei alkottak. Esetünkben két testület, a Testnevelési és Sporttudományi Szakmai Kollégium, valamint a Magyar Rektori Konferencia Sporttudományi Bizottsága koordinálja ezt a munkát.

2017-ig még párhuzamosan, de ettől a tanévtől kezdve már a bolognai rendszerü képzésben nem, csak az osztatlan tanárképzésben, szakpárban, általános iskolai szakon $4+1$ év alatt, középiskolai szakon $5+1$ év alatt lehet valaki testnevelő tanár, ahol a +1 év az összefüggő iskolai gyakorlatot jelenti. A képzés első három éve egyébként közös, ezt követôen válik szét a két szakasz.

A jelentkezés (egyik) feltétele az emelt szintű testnevelés-érettségi. Tapasztalataink szerint sikeresebb volt még akkor a képzés, amikor gyakorlati és elméleti (biológia, történelem) felvételi vizsga is volt. Ez jelenleg a törvényi háttér miatt nehezen kivitelezhető 
- a kizáró jellegủ motorikus próbát engedi csak. Kísérletet fogunk tenni arra, hogy visszaállítsuk a szakmai felvételi vizsgát is. Ez a követelmény alaposabb felkészültséget kívánna a hallgatóktól, és ez a képzés színvonalára pozitív hatást gyakorolna. Természetesen egészségügyi szempontból is alkalmasnak kell lenni a jelentkezóknek, hiszen jelentős fizikai terheléssel találkozik a képzés során. Ne gondolja senki, hogy pusztán „fizikai” jellegú képzés folyik, mert komoly, széles körü elméleti felkészítésben is részesülnek a hallgatók. Ezért támogatnánk a szakmai felvételi vizsga elméleti részét (biológia, történelem stb.), mert ez segítené azt a törekvésünket, hogy valódi sporttudósokat képezzünk.

Az osztatlan testnevelő tanári szak (általános $4+1$ és középiskolai $5+1$ év képzési idôvel) képzését az alábbi rendelet szabályozza. Talán érdemes szó szerint néhány elemét áttekinteni: 8/2013. (I. 30.) EMMI rendelet a tanári felkészités közös követelményeirôl és az egyes tanár szakok képzési és kimeneti követelményeiröl.

„A képzés célja az iskolai nevelés-oktatás, valamint az iskolai nevelés-oktatás szakképesítés megszerzésére felkészítő szakiskolai szakaszainak évfolyamain, a felnőttképzésben a testnevelés tantárgy tanítására, az iskola pedagógiai feladatainak ellátására. Képes olyan tanárok képzésére, akik a képzés során megszerzett képességek, kompetenciäk birtokában integrálni tudják a szakterületi és pedagógiai-pszichológiai ismereteiket. Alkalmasak a testnevelés tanitási-tanulási folyamatának tervezésére, szervezésére, irányitásá$r a$, testnevelés és sport müveltségének, az egészséggel, az életmóddal, a test kulturálásával kapcsolatos készségek, illetve képességek kialakitására, fejlesztésére, továbbá a tanulmányaik doktori képzésben történó folytatására."

A rendelet dôlt betûvel jelzett része jól illeszkedik a 157/2004-es kormányrendelethez. Ez a rendelet azt szabályozza, hogy milyen sporttal kapcsolatos tevékenységet milyen végzettséggel lehet ellátni. Ugyan a szabályozás talán megérett már egy felülvizsgálatra (pl. OKJ-s középfokú végzettséggel számos esetben ugyanolyan munkakört lehet betölteni, mint egy szakmai, mesterszakos diplomával), de alapvetően azt láthatjuk, hogy a testnevelö tanári végzettséggel a „sportpiacon” a jó szakember szinte bárhol elhelyezkedhet!

„4.2.1. A testnevelő tanár szakterületi tudása, készségei, képességei

$\mathrm{Az}$ általános iskolai testnevelô tanár ismeri a sporttudomány, a nevelés- és egészségtudomány alapfogalmait; a pszichomotorikus képességek és készségek fejlesztéséhez a testnevelés, illetve a sport célorientált eszközrendszerét; a mozgástanítás során a motoros tanulást elősegítő eljárásokat; a mozgáshibák jellemzőit, azok kijavításának módszereit; az ízület- és gerincvédelem elméletét és gyakorlatát; a testnevelés és a sport területén a felkészító folyamatok alapelveit.

Az általános iskolai testnevelő tanár alkalmas az általános iskolában a testnevelésóra pontos, szinvonalas tervezésére és vezetésére; felzárkóztató és tehetséggondozó programok szervezésére és vezetésére; versenyrendezôii, versenybirói, játékvezetói feladatok ellátására az általános iskolai és az iskolán kivüli utánpótláskorúak versenyrendszerében; edzótermekben és sportcentrumokban szakképzettségüknek megfeleló feladatok ellátására; sporttáborok, sportköri foglalkozások, sporttanfolyamok szervezésére és vezetésére. 
Az általános iskolai testnevelô tanár rendelkezik az egészséges életmódra, a fizikai erönlét fejlesztésére ösztönzó szemléletmóddal, az ember és környezete harmonikus egyensúlyára figyelmet forditó felelósségteljes magatartással.

További sajátos kompetenciák az általános iskolai testnevelő tanár esetében az iskolai és iskolán kívüli sportköri tevékenységekhez tartozó játék és sportfoglalkozások szervezése és levezetése; a tanult mozgáskészlet kreativ használata, eredeti mozgások, mozgásfolyamatok, játékok alkotása; olyan mozgásformák ismerete, amelyek divatosak, megfelelnek a korszellemnek; nyitottság az uij és bevált, jó gyakorlat iránt, hogy megfeleljenek az uij követelményeknek és kibivásoknak."

A fenti szabályozások értelmében sokoldalúan képzett, iskolában és azon kívül is alkotni képes, az élettudományoktól kezdve a társadalomtudományokon át a sporttudományig, elméleti és gyakorlati téren egyaránt kimúvelt szakemberról, pedagógusról van szó.

Mi magunk úgy fogalmazunk, hogy entellektüel típusú testnevelő tanárról van szó, akire minden iskolának és tanulónak szüksége van.

Amennyiben „tantárgyiasítani” szeretnénk a fenti kompetenciákat, az alábbiakkal találkozik egy hallgató.

\section{Mit tanul a testnevelő tanár szakos hallgató?}

- Közös képzési szakasz, valamint önálló differenciált képzési szakasz, továbbá a szakmódszertani szakasz ismeretkörei:

- medicinális alapismeretek (anatómia, biokémia, élettan);

- egészségtudományi ismeretek (egészségtan, sport- és iskolai egészségtan);

- kutatási alapismeretek;

- sporttudományi ismeretek (sporttörténet, testkultúra-elméleti ismeretek, edzéselméleti és képességfejlesztési ismeretek, mozgásfejlődés, mozgástanulás és -szabályozás, biomechanika, sportpedagógia, sportpszichológia, sportszociológia, sportrekreáció, EU és sport);

- sportmozgásos alapismeretek (gimnasztika, mozgásos játékok, zenés-táncos mozgásformák, tábor- és túravezetési ismeretek, általános és különleges sportágak ismerete);

- sportjátékok alapjai (kézilabda, kosárlabda, labdarúgás, röplabda);

- egyéni sportágak alapjai (atlétika, torna, úszás és uszodai sportok, tenisz, küzdôsportok);

- sportszakmai gyakorlat (egy választott sportág edzéseinek rendszeres látogatása);

- táborok (turisztikatábor, sítábor, vízi tábor).

- Az általános iskolai testnevelés szempontjából legfontosabb sportágak és mozgásterületek (alapsportágak, rekreációs és szabadidősportok) anyagának modern szemléletủ alkalmazása, oktatásának elmélete és módszertana. 
- Szabályismeret az általános iskolai testnevelés és az általános iskolai sport fontos sportágaiban, játékvezetői, illetve versenybírói ismeretek és gyakorlottság.

- A motoros képességek fejlesztésének elmélete és módszertana, az általános iskolai tanulók korcsoporti sajátosságainak figyelembevételével.

- A sporttevékenység megszerettetéséhez, az életen át tartó fizikai aktivitás iránti elkötelezettség kialakításához, e területen a tehetségek felismeréséhez és a tehetséggondozás feladataihoz szükséges ismeretek, tehetséggondozás (mentorálás) a diákolimpia I-IV. korcsoportjaiban; ismeretek, jártasságok, készségek az iskolai sport szervezeteinek működtetéséhez, illetve az I-IV. korcsoportos diáksportversenyek rendezésére, lebonyolítására.

- A sajátos nevelési igényü (fogyatékkal, krónikus betegségekkel élő, testi fejlődésükben lemaradó, elhízott) tanulók, hallgatók és felnőttek pszichoszomatikus fejlesztésének speciális ismeretei, a prevenció és a rehabilitáció kérdései.

- Gyakorlottság az integrált testnevelés- és sportfoglalkozások vezetésében.

- Ismeretek, illetve gyakorlottság sport- és rekreációs táborok szervezésében, vezetésében.

- A testnevelés elmélete és módszertana, a pszichomotoros tanítás-tanulás különböző stratégiái, tantárgy-pedagógiai sajátosságai.

- A tanítás-tanulás folyamatának sajátosságai a tanórai és a tanórán kívüli testnevelésben az egyes korosztályok szerint. Az elsősegélynyújtás és újraélesztés gyakorlata és oktatási módszerei.

- Az iskolai és iskolán kívüli sportköri foglalkozások szervezése, levezetése.

- A tanítási-tanulási folyamat motoros, valamint kognitív aspektusának tudatos transzferáló eszközként való alkalmazása tanórai és tanórán kívüli testnevelésben az egyes korosztályok oktatási ismereteinek figyelembevételével.

- Ismeretek és készségek a testnevelési tananyag tervezésére (tantervfejlesztés, tantervkészítés, tanmenetkészítés, óravázlat-készítés).

- Ismeretek és készségek a testnevelésióra, illetve a sportfoglalkozás szervezésére, vezetésére.

\section{Összefoglalás}

Ha valaki átnézi a fentiekben leírtakat, rájön arra, hogy nem a testnevelőtanár-képzés rendszerével van a baj. Lehet ezt új névvel, jelzőkkel illetni, pl. minőségi testnevelés, de a testnevelés képzési rendszerét eddig is a minőségi jelzővel illethetjük. Persze haladni kell a korral és a fiatalok változó igényeivel. De nem szabad a testnevelésórát, a tantárgyat „leminősíteni” testmozgásórává, hiszen akkor éppen a lényegét veszíti el. Nevezetesen itt találkozhat a tanuló a korlátaival, a hiányosságaival, de ezeket legyőzve olyan sikerélményt élhet át, amit más órán sehol. Sőt a „kinti életben” sem. Ugyanis a testnevelésórán lehetősége van a gyermeknek kilépni abból a korunkban mester- 
ségesen fenntartott komfortzónából, amihez hozzászokva felnőttként sem tud majd kihívásokat - legyen fizikai vagy szellemi (!) - legyőzni, problémákat megoldani. Ezt ne vegyük el a gyermektől!

De ahogyan valószínűleg Önök is találkoztak már sajnos - előre is elnézést kérek a példákért - rossz autószerelővel, jogásszal, kőművessel, tanárral vagy orvossal, sajnos igen, ki kell mondani, vannak olyan testnevelők is, akik nem öregbítik szakmánk hírnevét. Ezért egyre nagyobb figyelmet kell fordítanunk a minőség-ellenőrzésre, ami már elindult, de még nagyon-nagyon gyerekcipőben jár. De ez nem a testnevelés, nem a teljes rendszer hibája. Az adott egyéntől függ, aki a terepen, a tornateremben, a csarnokban, az atlétikai pályán a gyermekekkel foglalkozik, hogy milyen lesz a testnevelésünk.

Ahogyan mondani szoktam testnevelö szakos hallgatóimnak: akkor lesznek jó szakemberek és készek a pályára, ha a legdrágább kincsüket, a saját gyermeküket oda merik engedni magukhoz az órára. Minden órára úgy kell bemenni, hogy Önökre bizta valaki a legdrágább kincsét. Ezzel a bizalommal nem szabad visszaélni.

Végül, de nem utolsósorban, meleg szívvel javasolom mindenkinek, hogy olvassa el, mit lát a „a piac” másik fele, a felvevő. Mi a tapasztalat a valódi életben, a terepen.

Kis Mihály: Merre tovább magyar testnevelötanár-képzés?

Egy sportiskola igazgatójának szemével, aki történetesen maga is testneveló tanár

Erre a kérdésre megfeleló választ akkor tudok adni, ha elmondom, hogy a pedagógusi pályán eltöltött 32 évemböl 16 évet iskolaigazgatóként sportiskolában, illetve ugyanannyit testnevelést tanítva töltöttem. Ezekkel a tevékenységekkel párhuzamosan 23 éven keresztül 5-6 éves óvodások részére ovis tornát tartottam két óvodában.

Az Újbudai Grosics Gyula Sport Általános Iskola igazgatójaként és testnevelö tanárként fejtem ki véleményemet, aki a Budapesti Diáksport Szövetség elnökségi tagja már 20 éve.

Aki testnevelónek tanul, fel kell készülnie az alábbi feladatok ellátására:

- betente 22-26 órát tanit;

- osztályfönökként/munkaközösség-vezetöként kell ténykedni;

- délutáni és egyéb sportfoglalkozásokat szervezni, illetve tartani;

- a tanév során a sport-, illetve egyéb rendezvényeken felmerülö technikai feladatok megoldása (hangositás, teremberendezés stb.);

- téli/nyári sporttáborok szervezése;

- gyerekek kisérése kerületi, budapesti vagy országos versenyekre;

- pályázatok irásával, szponzorok felkutatásával fejlesztheti az iskola sportfelszerelését és sportinfrastruktúráját;

- megszervezi és lebonyolitja a NETFIT éves mérést;

- nagyon fontos feladatuk a házirendnek megfelelóen a rend, a fegyelem betartatása az iskolában.

A felsoroltak alapján látszik, hogy milyen sokféle munkát kell elvégezniük a testnervelöknek az iskolában. 
De hol lehet ilyen képzett testneveló tanárt találni, aki elméleti, gyakorlati, módszertani ismeretekkel rendelkezik? Pláne olyat, aki tudja, mit, miért és hogyan kell tanitani testnevelésiórán elsó évfolyamtól a tizenkettedik évfolyamig. Aki észreveszi a gyerekekben a tehetséget és csapattá formálja óket, vagy egyesületi sportolásra ösztönzi a kiemelkedö tehetséget/tehetségeket, akikkel késöbb komoly eredményeket érhet el.

Egy elkötelezett testnevelö tanár mindent megtesz azért, hogy vezetötanárként, mentortestnevelóként vagy mesterpedagógusként segítse az egyetemista diákokat vagy a gyakornok tanárok munkájának kiteljesedését.

Ki tudja ezt a sok kompetenciát megrvalósitani testneveló tanárként? Sajnos az elmúlt egy érben, amióta mesterpedagógusként minósitek vagy minósitö vizsgán szakértóként tevékenykedek, igen komoly problémákkal szembesülök, föleg a gyakornok tanárok esetében. A problémákkal már a Testnevelési Egyetem felvételi vizsgabizottságának tagjaként is találkozok, amikor olyan diákok is jelentkeznek, akiknek a képességei és készségei nem megfelelö szintüek. Itt döbbenek rá arra, hogy megfelelö adottsággal rendelkezó hallgatók kiválasztásához a felvételi ponthatárokat meg kell emelni a mai 280-330 körüli pontszámról (ami eddig a TF-re volt jellemzö) legalább 400-ra, annak érdekében, hogy a maximális 500 ponthoz minél közelebb legyenek a mi felvételizóink. A Testnevelési Egyetemnek, mint a testnevelötanár-képzés „zászlós hajósának”, új alapokra kell helyeznie a testnevelésképzést. Sokkal igényesebben, tudatosabban, szakszerübben kellene kiválasztani azokat a diákokat, akikböl a jövö testnevelöi lesznek. Amennyiben minden marad a régi bevált rutin szerint, nagy a valószinúsége annak, hogy a XXI. századi, kiváló tárgyi feltételekkel rendelkezó budapesti Testnevelési Egyetem nem fogja betölteni vezetö szerepét a testnevelötanár-képzésben. Söt nem fogja azt a szakmai elvárást teljesiteni, hogy a testneveló tanár a tantestület nagyon megbecsült tagja legyen. Mindezekhez hozzá kell tennem, hogy egyik-másik leendö egyetemista olyan neveltségi (neveletlenségi) szinten van, ami nem felel meg az alapkövetelményeknek. Az öltözködésük, az olvasottságuk, a szóban való kifejezóképességük olyan gyatra, hogy legtöbbjüket még az egyetem közelébe sem engedném! A pedagógus kinézete, viselkedése, megnyilatkozásai egyfajta modellként, példaként jelenik meg a gyerekek iskolai nevelö munkájában.

A gondolatot folytatva, a leendö egyetemistáknak meg kell érteniük, hogy tanitani csak olyan "példakép" tud, aki hiteles, aki nagyon komoly elméleti és gyakorlati ismerettel rendelkezik és ezt át is tudja adni diákjainak. A fiatalok többségének sekélyes az elózetes tudásuk a testnevelésröl és sportról, nem tudják, miért szeretnének erre a pályára jelentkezni. Fontos lenne, hogy a jelentkezók legalább 5-6 éves sportolói múlttal rendelkezzenek annak érdekében, hogy bitelesen tudják bemutatni a testnevelési feladatokat, sportági technikai és taktikai elemeket.

Miért fontos ez? Akkor lehet minóségi testnevelésiórát tartani, ha a tanár tudja az elméleti és gyakorlati tényezőket összehangolni a motoros tevékenységek során. Amikor a pedagógus jól felépitetten képzi a tanuló mozgását, úgy, hogy ó megfelelő koordinációs és kondicionális állapotban van. Megfeleló technikai és taktikai tudással rendelkezve lehet egy sportágat magas szinten üzni vagy alkalmazni különbözö rekreációs tevékenységekkor (streetball, strandröplabda). 
A mindennapos testnevelés bevezetése az 1-12. évfolyamon különbözó anomáliákat generált, s ezért támadják az iskolában, a szakszervezetek, akik szerint más tantárgyak óraszámát kellene megemelni. A mindennapos testnevelés bevezetése egy egészségprogram, biszen a fiatalok nagy része kizárólag csak a testnevelésórán mozog. Az inaktiv, mozgásszegény életforma következtében minden harmadik gyerek túlsúlyos vagy kövér, és ezért számtalan fiatalnak különbözó egészségügyi problémája van. Rengeteg pénz kell a korai rehabilitációra!

Hogy jutottunk ide, hogy saját testneveló tanáraink is nehézségnek, bajnak érzik a mindennapos testnevelés megtartását, megszervezését, tartalommal való ellátását? Az a testnevelö tanár, aki nem látja ennek a tevékenységnek a preventív, egészségmegórzó feladatát, merényletet követ el saját tantárgya ellen.

Nem hiszem, hogy a most megjelenó problémák (tornaterem, fedett pályák, sportudvarok biánya) nem fognak az elkövetkezendó években megoldódni, biszen a stadionépitéseknek csak igy van értelme. De addig is mindenki, aki a testnevelés, a sportági képzés, a rekreáció, preventív tevékenység körül dolgozik, tegyen meg mindent a minöségi, mennyiségi és megfeleló intenzitású motoros tevékenység végrehajtásában a gyerekeink érdekében.

A rendszerváltáskor megépitett sok száz sportinfrastruktúra-fejlesztés az elmúlt 25 évben iskolai szinten megtorpant, itt az ideje, hogy régi és új célok érdekében újra beinduljon a sportcsarnokok és sportpályák épitése. Csak itt, a közoktatásban, köznevelésben kialakitott egészségrédö, egészségerösitő szemlélettel lehetünk sikeresek a jövóben.

Ehhez viszont összefogásra, együtt gondolkodásra és együtt cselekvésre van szükség. Minden testnevelönek át kell éreznie az ügy fontosságát, mert ha nincs megfeleló válasz ezekre a problémákra, akkor a mindennapos testnevelés nem fog az új NAT-ban ilyen módon megjelenni, és visszacsúszunk a négy évvel ezelötti állapotba (heti 2-2,5 óra testnevelésiórák).

Cselekedjünk mindannyian, hogy ezek a célok megvalósulhassanak, azaz épüljön meg az a 240 tornaterem, ami ma hiányzik, és képezzünk igen magas szinten testneveló tanárokat, mert csak igy tudjuk teljesiteni küldetésünket.

\section{Hivatkozott irodalom}

- Báthori B. (1994). A testnevelés elmélete és módszertana. Budapest, MTE.

- Domokos M. (2013). A testnevelés és sport tanitásának elmélete és módszertana. Szeged, SZTE JGYPK.

- H. Ekler J. (2011). Nevelés, egészségnevelés, testnevelés. In Dr. Nádori L., dr. Gáspár M., dr. Rétsági E., H. dr. Ekler J., Szegnerné dr. Dancs H., dr. Woth P. \& dr. Gáldi G. (szerk.): Sportelméleti ismeretek. Pécs, Dialóg Campus Kiadó-Nordex Kft. Forrás: http://tamop412a.ttk.pte.hu/TSI/Nadori-Dancs-Retsagi-Ekler-Gaspar\%20 -\%20Sportelmeleti\%20ismeretek/sportelmelet.html\#d5e426. Utolsó látogatás: 2016. 08. 30.

- Rétsági E. \& H. Ekler J. (2011). A testnevelés elmélet és a testnevelés módszertan alapjai. In Dr. Nádori L., dr. Gáspár M., dr. Rétsági E., H. dr. Ekler J., Szegnerné 
dr. Dancs H., dr. Woth P. \& dr. Gáldi G. (szerk.): Sportelméleti ismeretek. Pécs, Dialóg Campus Kiadó-Nordex Kft. Forrás: http://tamop412a.ttk.pte.hu/TSI/NadoriDancs-Retsagi-Ekler-Gaspar\%20-\%20Sportelmeleti\%20ismeretek/sportelmelet. html\#d5e426. Utolsó letöltés: 2016. 08. 30.

\section{Dokumentumok}

- 8/2013. (I. 30.) EMMI rendelet a tanári felkészítés közös követelményeiről és az egyes tanárszakok képzési és kimeneti követelményeirôl.

- 157/2004. (V. 18.) Korm. rendelet a sport területén képesítéshez kötött tevékenységek gyakorlásához szükséges képesítések jegyzékéről. 


\title{
Orosz Róbert, Jónás Péter
}

\section{Új generáció - új szemléletek és utak a sporttehetség gondozásában}

\begin{abstract}
Absztrakt
A tanulmány célja a sportot tágabb összefüggésrendszerbe helyezve pedagógiai-pszichológiai szemszögből tárgyalni a rendszerek összetett fejlődésével járó, szükséges változásokat a sporttehetség-gondozásban. A különböző generációk lélektani jellemzőiből adódóan más-más pedagógiai-pszichológiai szemlélet lehet szükségszerú a velük való munkában. A tanulmányban bemutatunk pszichológiai elméleteket, melyek hátterével a sportot az élet egy fontos részének tekintjük, ami a rendszerek fejlődésének folyamatában segítheti az egyén kiteljesedését. Felvázolunk a különböző generációk személyes pszichológiai és társas viselkedési jellegzetességeit taglaló elméleteket, melyek alátámasztják az eltérő lélektani jellemzők, illetve igények nyomán felmerülő szemléletváltás szükségszerüségét. Különbséget teszünk a fejlődést, illetve a teljesítményt fókuszba helyező nevelői szemlélet, továbbá a kiteljesedés igényéből kiinduló és az elvárásokra alapozó szemléletek között. Végül a tehetséggondozás integratív szemléletéből kiindulva bemutatunk egy sporttehetség-gondozó gyakorlati programot - a Tehetséghidak program sporttehetségtáborát -, melyben a fejlődés és kiteljesedés szemlélet egyaránt megjelenik.
\end{abstract}

\section{Bevezetés}

Személyiségünkből, családi mintáinkból, az aktuális társadalmi elvárásokból és értékekből adódóan sokféleképpen állhatunk az élethez és sokféleképpen állhatunk a sporthoz. Szemléletünk meg fogja határozni, milyen hozzáállással dolgozunk a tanítványokkal, milyen célokat tüzünk ki, milyen módszereket részesítünk előnyben, hogyan törődünk vagy nem törődünk a lelki tényezőkkel, hogyan kommunikálunk velük. A szemlélet összefügg a személyiséggel, valamilyen szinten elválaszthatatlan attól, de könnyebben változtatható, formálható. Mindkettő mélyen a korábbi tapasztalatokban gyökerezik, ugyanakkor a szemlélet változásához az új tapasztalatoknak, az újonnan tanulható komponenseknek nem feltétlenül szükséges a személyiség legmélyére hatolni, míg a személyiség változásához igazán mélyreható befolyások szükségesek. A különböző generációk más-más érzelmi, kommunikációs, kapcsolati mintákkal, illetve értékrendekkel rendelkeznek. Eltérő politikai, ideológiai, társadalmi közegben nevelkedtek. Ezek a különbségek meghatározzák az oktatással kapcsolatos szemlélete- 
ket is. Az egyik generációnál beváló szemlélet, illetve az ahhoz kapcsolódó pedagógiai és pszichológiai módszertan nem feltétlenül lesz hatékony egy alapvetően más lelki alkattal, hozzáállással, motivációs bázissal rendelkező generációnál. Ezért is tapasztalhatják bizonyos esetben a korábban sikereket elért edzők vagy nagy tekintélynek örvendő pedagógusok, hogy jól bevált módszereikkel már nem úgy tudnak hatni a sportolókra, diákokra. Ebben a tanulmányban szeretnénk a sportot az élet és a fejlődés tágabb összefüggésébe helyezni, bemutatni alternatív szemléleti kereteket, illetve gyakorlati példát hozni az integratív szemléletú sporttehetség-fejlesztésre.

\section{Élet, sport, fejlődés}

A sporttehetség-gondozás hajlamos beszúkülni a jelen- vagy jövőbeli teljesítmény felmutatására. Ilyenkor maga az ember - a gyermek lénye, szükségletei, lelki történései - könnyen háttérbe szorulnak. Egy érdeklődésében teljesen egyoldalú, túledzés miatt hónapok óta sérült fiú, arra a kérdésre, hogy milyen dolgok okoznak neki örömet, így válaszolt: „A szüleim azt mondták, hogy most inkább csak a focival foglalkozzam.” Egy másik, egyébként válogatott szintű játékos ezt fogalmazta meg: „Akkor örülök a játéknak, ha nincs ott apa. Egyébként arra figyelek, hogy megfeleljek neki." Ha a teljesítmény és eredmény válik mindenekfelettivé egy utánpótlás-sportoló fejlesztésében, az - amellett, hogy hozhat eredményességet - könnyen tönkreteheti az életét. Erre szélsőséges, de nem is túl régmúltból származó, élő példa a pártpropaganda okán gyermekkortól doppingolt NDK-s sportolók esete, akik közül sokaknak teljesen zátonyra futott az élete. Az ilyen jellegú sporttehetség-fejlesztésben eltủnik az ember, s a nagyszabású célok mögött háttérbe szorul az élet.

Egészen más céljai, kimenetelei, hozadékai lehetnek a fejlesztésnek, ha a sportot nem mindenekfelettinek, csupán az élet egy részének tekintjük, és a puszta teljesítménynél tágabb kontextusba helyezzük. Ilyen tágabb összefüggésben a sport által teljesebb életet lehet élni. Életre szóló baráti kapcsolatok szövődhetnek, utazás, világlátás és még számtalan más lehetőség nyilhat meg. Egy tágabb összefüggésben a sport megjelenhet mint a személyiségfejlődés és kiteljesedés támogatója. Például megfelelő körülmények között a sporttevékenység ténylegesen kedvező hatással van az akarat és önbizalom fejlődésére. Tágabb kontextusból szemlélve a sportban mint szimbólumban összesúrítve megjelennek az élet jelentős területei. Például a küzdelem vagy az emberi viszonyok összetettsége egy zárt, átláthatóbb rendszerben megélve felkészíthet az élet egyéb területein való hatékonyságra.

A továbbiakban a sporttehetség fejlődését egy ilyen tágabb összefüggésrendszerben szemléljük. Tehát a sportot az élet részének tekintjük, mely - jó esetben - támogatja az egyén fejlődését és kiteljesedését. 


\section{Egyéni és kollektív fejlődés a rendszerekben}

A fejlődéslélektanban legmarkánsabban Eirk H. Erikson pszichoszociális fejlődéselméletében (Erikson 2002) jelenik meg az életen át tartó fejlődés gondolata. Erikson szerint minden fejlődési szakaszban megvan az egyén megvalósítandó életfeladata, amely fejlődési krízisben nyilvánul meg. Az ember ezekben az életkori krízisekben kihívásokkal szembesül, melyek megoldása garantálja az egészséges fejlődést. Az első életszakasz az ember születésétől egyéves koráig tart. A megvalósítandó cél az, hogy kialakuljon az ember a világgal szemben érzett bizalma. E bizalom kialakulását segíti, ha a baba megtanulja, hogy a róla gondoskodó személyek állandóak, ő maga szerethetô, és az igényei kielégülnek a róla gondoskodó környezet által. Az anyai kapcsolat minősége döntő szerepet játszik ebben. Ez a bizalom fogja adni késóbb az önbizalom alapját is (Baumann 2006). A következő szakasz feladata Erikson szerint az autonómia kialakulása a szégyennel és kétellyel szemben. A gyermek legfóbb feladata itt egy- és hároméves kora között -, hogy képes legyen elkezdeni önállóan felfedezni az őt körülvevő világot kétségek és szégyenérzet nélkül. A gyermekek kezdeményezőkészsége, önállósága három és hat év között szilárdul meg. A járni tanulás és a gyermekkori genitalitás kiemelt szerepet játszik ebben a szakaszban. A gyermek megtapasztalja saját autonómiáját és korlátait, rájön, hogy manipulálhatja a környezetében található tárgyakat és személyeket. Megjelenik a testvérekkel történő versengés, az irányukban érzett féltékenység. Kezdetét veszi a gyermek erkölcsi felelősségérzetének kialakulása. A szakaszban szerzett tapasztalatok következtében kedvezőtlen esetben a személy túlzottan gátlásossá, önmagát tehetetlenként megélővé vagy gátlástalanná válhat. A teljesítményhez való hozzáállással kapcsolatban nagyon nagy jelentősége lehet a következő szakasznak, melynek Erikson a „teljesítmény a csökkentértékűséggel szemben” nevet adta. A hat- és tizenkét éves kor között a gyermek a legtöbb kultúrában valamilyen formális oktatásban részesül, melynek során megtapasztalja saját alkotó- és teljesítōképességét. A gyermekek egy olyan közösségbe kerülnek, amely a családtól eltérő kultúrával, célokkal, korlátokkal, értékekkel rendelkezik. E közegben a nevelői és kortársi visszajelzések által saját kompetenciáját, illetve a kudarcokat, csalódásokat egyaránt megtapasztalhatja. $\mathrm{E}$ hatások függvényében egy általános én-hatékonyság-érzés vagy - negatív kimenetel esetén - inkompetencia- és kisebbrendúségi érzés alakulhat ki.

A személyiség integrálódásának kezdete, önmagunk világban történő elhelyezése a tizenkét és tizennyolc éves kor közötti időszak legfontosabb fejlődési feladatai. Serdülókorban megkérdőjeleződnek azok az azonosságok, amelyekre a személy korábban támaszkodott. Ebben vezető szerepet játszik a fizikai és genitális fejlődés. Az identitás kialakulása során fontossá válik a példaképek és az „ellenségek” szerepe, a csoportokhoz tartozás, valamint a serdülőkori szerelmek. A serdülók gyakran azonosulnak más személyekkel és csoportokkal, fogékonnyá válnak a különböző eszmékre és ideológiákra.

Fiatal felnőttkorban sajátítjuk el az intim kapcsolatok kialakításának képességét. A fiatal felnőtt életfeladata az, hogy képessé váljon bensőséges kapcsolatokat kialakítani másokkal, és elég erkölcsi erőt fejlesszen ki ahhoz, hogy el tudjon köteleződni. Ez 
a folyamat lemondásokat és kiegyezéseket követel. Amennyiben a személy nem válik képessé az önfeladásra és elköteleződésre, elszigetelődhet.

$\mathrm{Az}$ „alkotóképesség a stagnálással szemben” szakasza a felnőttkor azon részét fedi le, melynek során az ember munkája révén megtapasztalja saját alkotóképességét. Az érett ember szükségleteihez hozzátartozik, hogy hasznosnak és fontosnak élje meg magát, hogy úgy érezze, az új nemzedéknek szüksége van az ő iránymutatására. $\mathrm{Ku}$ darc esetén megrekedésérzés uralkodhat el a személyen.

Időskorban az élet során megszerzett tapasztalatok integrálása a legfontosabb feladat. Az én-teljességet elérô ember tudatában van az emberi küzdelmek értelmével, és kész arra, hogy elismerje saját életstílusát és méltóságát. Életstílusa „lelkének örökségévé" válik. A szilárd én-integritással rendelkező emberek életciklusukat végleges és teljes életként fogadják el, így könnyebben néznek szembe a halállal.

Az elsődleges szociális környezet, melyben az ember - az eriksoni modell szerint - az életkori krízisekkel megküzdve fejlődik, s egyre integráltabb személyiséggé válik a család. A családi életciklusmodellek ${ }^{1}$ szerint a család mint rendszer önmaga is fejlődik, s a rendszer tagjainak megvannak a közösen megvalósítandó életfeladatai. Az egészséges fejlődést és életvitelt az támogatja, ha az adott életciklusban a rendszer megfelelően meg tudja oldani az adott élethelyzetet. A közelmúltban több ilyen modell is született. Carter és McGoldrick (1989) hatfázisú családi életciklusmodelljének első fázisa a nőtlen vagy hajadon fiatal önálló életének kezdete. Itt a származási család feladata a leválás, elszakadás támogatása, a fiatalnak pedig az önálló életvezetés kialakítása. A második fázis feladata a családok kapcsolódása a házasságon keresztül. Hogy ez hosszabb távon is sikeresen múködjön, ahhoz a hozott minták, szokások, értékek egyeztetése szükséges. A harmadik fázis a kisgyermekes család. Ebben a családtagok feladatai közé tartoznak az új szerepek (például anya, apa) megvalósítása, ezeknek az eddigi szerepekkel való egyeztetése (például nő- és anyaszerep), a feladatok kielégítô elosztása, vagy éppen a származási családtagok (anyós, após) helyének, szerepének megtalálása. A következő szakaszban - a család tinédzser korú gyerekkel - szintén új kihívások elé néz a család (ilyen például a gyermekhez való viszony átalakítása). Az ötödik fázisban, a gyermekek önállósodásakor a „kiürülő családi fészek” szintén új élethelyzetet, kihívásokat és problémákat teremt. Végül az idős szülők családja fázisában szembe kell nézni a veszteségekkel, közben pedig a családtagok a támogatóságot és a támogatottságot egyaránt megélhetik.

Tehát miközben a családban mindenki a saját életkori fejlődési feladatával küzd, addig maga a családi rendszer is fejlődik és közösen megvalósítandó fejlődési fázisokon megy keresztül (lásd 1. ábra). Nem nehéz belátnunk, hogy a fejlődés minősége befolyással van arra, hogy az egyén, illetve a rendszer minél magasabb energiaszinten, minél egészségesebben és hatékonyabban tudjon múködni. Még összetettebbé teszi

1 http://semmelweis.hu/klinikai-pszichologia/files/2012/06/Dr.-Koml\%C3\%B3si-Piroska\%C3\%89letciklusv\%C3\%A11t\%C3\%A1sok-a-csal\%C3\%A1dban.pdf 
a képet, hogy a családi rendszerben különböző generációk vannak jelen az ő saját generációs jellemzőikkel, mintáikkal, értékeikkel, melyeket fontos összehangolni ahhoz, hogy a családtagok a legmegfelelőbben támogatni tudják egymást a fejlődési feladatok megoldásában.

A szervezetek - köztük a sportszervezetek - működése sok szempontból analóg a családokéval. Az analógia markánsan érzékelhető a fent tárgyalt tényezők - azaz az egyéni fejlődés, a rendszer egészének fejlődése, illetve a több generáció együtt, másmás jellemzőkkel és igényekkel való jelenléte - együttes meglétében.

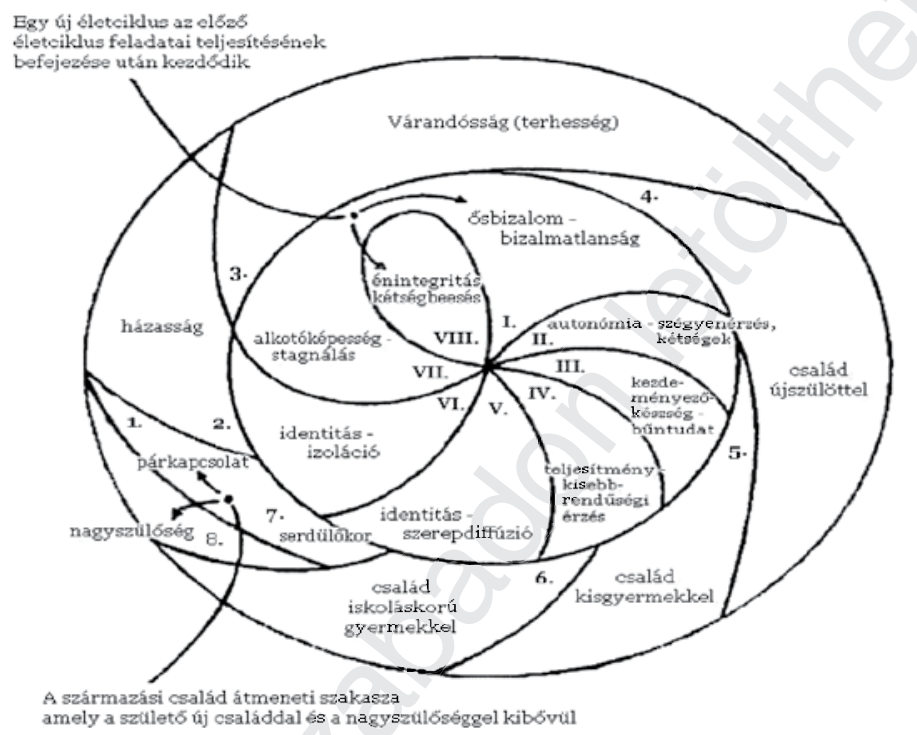

1. ábra. Az eriksoni pszichoszociális fejlődés szakaszainak a családi életciklus nyolc fázisával való öszefüggése (Kurimay 2004: 163)

\section{Generációk és jellemzőik}

McCrindle és Wolfinger (2010) szerint a generációt hagyományosan a szülők és gyermekeik születése közötti átlagos intervallumként (20-25 év) határozták meg. Ez a definíció azonban mára elavulttá vált, ugyanis a fiatal generációk manapság gyorsabban változnak, válaszul a felgyorsult technológiai fejlődésre, a tanulási opciókra, az átalakuló karrierre, valamint az eltolódó társadalmi értékekre. A szülők és utódaik születése közötti időszak harminc évnél többre tágult. Előbbiek következtében a nemzedék meghatározása ma már inkább a szociológia, mintsem a biológia feladata.

A generációkutatás alapjainak letétele Strauss és Howe (1991) nevéhez füződik. A szerzők úgy mutatják be a generációkat, hogy archetípusokat és korszakokat rendelnek hozzájuk. A négy archetípus, a próféta (idealista), a nomád (reaktív), a hős (polgári) és a művész (alkalmazkodó) ciklikusan ismétlődik. Az általuk átélt korszakok 
sajátságai (gazdasági és társadalmi jellemzők, a technika és a tudományok színvonala) jelentős különbségekhez vezet a különböző generációk között (az azonos archetípushoz tartozóak között is).

Az első világháború után születettek nemzedéke a csendes generáció (vagy veteránok nemzedéke), melyhez az 1925 és 1942 között születetteket sorolják. Ôk az alkalmazkodó (vagy müvész-) generációkhoz tartoznak. Értékrendjükben a béke és a család kitüntetett szerepet kapott. Őket követi a „baby-boom” generáció (1943-1960), akiket a próféta archetípusával jellemeznek. Ennek a nemzedéknek a fiatalkora a lázadás jegyében telt, idealisták. A korábbi nemzedék értékei nem olyan fontosak számukra, önmegvalósítás jellemzi ôket, törekszenek saját akaratuk érvényesítésére. A megfelelés és szakmai tudásuk mélyítése motiválja őket (Strauss \& Howe 1991).

\section{AzXés az Ygeneráció}

Az X generáció (1961-1981, „nomád”, reaktív) névadója Douglas Coupland (2007), az elnevezést regényéből vette át a társadalomtudomány. A szerző kifejti, hogy az Egyesült Államokban akkoriban ennek a nemzedéknek még nem volt neve, Japánban azonban „shinjinrui-nak”, azaz új emberi lényeknek nevezik őket.

Az X generáció képviselői elsősorban a megoldásokat keresik. Megbízhatóak és kontrolláltak. A karrier, a státusz, a pénz és a társadalmi pozíció motiválja ôket (Strauss \& Howe 1991). Függetlenségre törekszenek, jól alkalmazkodnak és rugalmasak. Az óket megelőző generációval szemben nem azért élnek, hogy dolgozzanak, hanem azért dolgoznak, hogy éljenek. Előbbi tulajdonságaik annak megtapasztalásából fakadnak, hogy szüleik számára elsőbbséget élveztek a munkahelyi érdekek, emiatt rengeteg áldozatot hoztak (Gursoy et al. 2013). Tulgan (2004) szerint az X generáció tagjai számára fontos a csapatmunka, a visszajelzés, a rövid idôn belül történő jutalmazás, a függetlenség és a vállalkozó szellem. Szívesen bővítik ismereteiket. Szkeptikusak a hierarchiával szemben, vezetőik cselekedeteik és nem tekintélyük által vívhatják ki tiszteletüket.

A millenáris (más néven Y) generáció (1982-1995, „hős”, polgári) tagjai gondoskodó szülők által és biztonságos környezetben nevelkedtek. Arra ösztönözték őket, hogy önálló döntéseket hozzanak, és hogy kritikával viszonyuljanak az autoritás felé (Nobel et al. 2009). Az engedékenyebb erkölcsi normák és a magasabb válási arányok által kiváltott ellenállás következtében később házasodnak, mint az ôket megelőző generációk (McCrindle \&Wolfinger 2010). Kreativitás és tehetség jellemzi ôket, koncentrációs képességük és teljesítményük azonban csökkent a korábbi generációkéhoz képest. Gyakran céltalanok és kiszámíthatatlanok. Az ő általuk megtapasztalt világban az informatika már kiemelt szerepet kapott, gyermekkoruktól fogva használnak digitális eszközöket. A kortárs csoport számukra jelentősebb, együttmúködőek (Strauss \& Howe 1991). Türelmetlenné válhatnak az olyan helyzetekben, amelyek érdektelenek számukra, könnyen alkalmazkodnak multikulturális közegben (Pais 2013). 


\section{$A Z$ generáció}

Ezt a generációt többféle elnevezéssel is ellátták már. Nevezik N (mint net-) generációnak, de a D (mint digitális) generációként is ismertek. Prensky (2001) szerint leginkább a „digitális bennszülött” kifejezéssel írhatóak le, ugyanis „anyanyelvi szinten” beszélik a számítástechnika és a világháló digitális nyelvét. Egyszerre több feladat végzésére is képesek. Kötődési mintázatuk lazább, jellemzően egészségtelenül táplálkoznak és keveset mozognak. A korábbi generációkhoz képest idősebb anyáktól születtek. Kevesebben vannak, mint az őket megelőző nemzedékek tagjai, várható életkoruk magasabb, és jobb színvonalú oktatásban részesültek (Pais, 2013). Családjaikban nagyobb a válások gyakorisága, szüleik rengeteget foglalkoznak munkájukkal és karrierjükkel, ezért kevesebb időt töltenek gyermekeikkel. A „digitális bennszülöttek” általában kisebb családokba születnek. Szüleik jellemzően az X és az Y generációból kerülnek ki. A $\mathrm{Z}$ generáció kezdetét eltérően állapítják meg, egyesek a kilencvenes évek elejét, mások a közepét jelölik meg. Nevelésükben hatástalannak bizonyulnak a tekintélyelvú nevelési módszerek, elvárják, hogy szüleik egyenrangú partnerként kezeljék őket (Tari 2011). Ez feltételezhetően összefügg azzal a jelenséggel is, melyet Csepeli (2003) fordított szocializációként jellemez. Korábban a fiatalok függtek az idősebb generációktól, az elmúlt időszakban azonban a technológiai újításokra fogékonyabb, nagyobb felfedezőkedvvel rendelkező, plasztikusabb idegrendszerű fiatalok előnybe kerültek, ők váltak az információk birtokosaivá. Ebből adódóan az idősebbek tekintélye megrendült.

Életük nagy részét a virtuális térben (televízió, internet, számítógépes játékok) töltik, ezért gyakran szembesülnek diszfunkcionális viselkedéses mintákkal (pl. túlreprezentált agresszió), melyeket referenciaként alkalmazhatnak a valódi életre, ezért a normalitásról alkotott képük sok esetben eltérő lehet más generációkétól. Nagyobb önállóságot igényelnek, hedonistábbak, kockázatvállalóbbak és agresszívabbak. Amenynyiben nem alakítanak ki jelentős kapcsolatot hús-vér emberekkel, elidegenedhetnek környezetüktől, önértékelésük, érzelemszabályozásuk és önkontrolljuk problémásabb lehet (Tari 2011). Fokozottan ki vannak téve annak a veszélynek, hogy esetükben elmagányosodás, szorongás és fokozott agresszivitás alakul ki (Pais 2013).

A digitális generáció tagjai a korábbi generációktól eltérő sajátosságaik következtében unalmasnak találhatják a hagyományos oktatást (Oblinger \& Hagner 2005 idézi Akçayir et. al. 2016). Előnyben részesítik a képeket az írott szövegnél, azokat a kommunikáció területén is szívesebben használják (Teo et al. 2014; Akçayir et al. 2016). A Copaci és Rusu (2015) által végzett vizsgálat eredményei szerint az interneten keresztül megvalósuló tutorálás növelte a $Z$ generáció tagjainak teljesítményét, továbbá hatékonynak bizonyult társas készségeik és a tanulási stratégiák fejlesztésében. Verčič és Verčič (2013) felmérése szerint a digitális generáció tagjai gyakran nem tudják, hogy hol és hogyan tegyék fel kérdéseiket tanáraiknak. A szerzők úgy vélik, előbbi kommunikációs probléma kezelhetővé válna, ha az oktatási intézmények elérhetővé válnának a közösségi médián keresztül. 
A hálózatiság és az ezáltal hozzáférhetővé váló, szinte minden ismeretet lefedő információ meghatározó a digitális nemzedék számára. Ez nagyban megkülönbözteti őket szüleik és nagyszüleik generációitól. A szociológiai kutatások szerint az információs korszak Magyarországon sem kerüli el a többséget. Az új évezred első évtizedeiben születettek nagy része részesévé válik (Csepeli 2003).

A fentiek alapján érthető, hogy az új generációknak folyamatosan változó, saját jellemzőikhez és igényeikhez igazodó képzésekre van szükségük.

\section{Szemléletek generációs küzdelmei}

\section{„Légy elégedetlen” vagy „teljesedj $k i ”$}

A sportpszichológiai kutatás fontos céljai közé tartozik a sportteljesítményt meghatározó összefüggések és feltételek feltárása. A teljesítménymotiváció és a hangulati állapotok bizonyítottan szerepet játszanak a sportteljesítmény alakításában (Lochbaum \& Gottardy 2015). Sok élsportoló már kora gyermekkora óta foglalkozik versenysporttal, ez a tevékenység meghatározóvá válik identitásuk képzése során (Baillie 1993). Ezért is nagyon fontos kérdés, hogy a képzése milyen szemléletben zajlik. A nevelők szemlélete meghatározza, hogyan próbálják motiválni, teljesítményre sarkallni a sportolót, és azt is, hogy milyen mértékben foglalkoznak a sporttevékenységhez füződő érzelmi állapotok hatásával. Gyakorlati sportpszichológiai munka során gyakran megfigyelhetők az egymással ellentétes szemléletek „küzdelmei”. Egy hagyományosabb, korábbi pedagógiai elvekhez kapcsolható szemléletben a teljesítménymotivációt úgy akarják az edzők vagy éppen a szülők serkenteni, hogy megpróbálják a sportolót önmagával elégedetlenné tenni. Kihangsúlyozzák a gyengeségeit, hibáit, kritizálják, azt remélve, hogy így majd „magába száll” és bizonyítani akar. Erre a „légy elégedetlen és akarj bizonyítani” szemléletre példa az edző, akinek ars poeticájának egyik fő mondata a következő: „A jó dolgokat meg kell említeni, a hibákat ki kell emelni.” Ô úgy gondolja, hogy a pozitív dolgok hangsúlyozása inkább csak elégedetté, önelégültté tenné a versenyzőt. Hasonló példa a szülő esete, aki, amikor gyermeke több győztes asszó után, az elődöntő előtt leült mellé pihenni, ezzel a gondolattal kívánta még jobb teljesítményre sarkallni: „Úgy látom, az utóbbi időben a többiek sokkal többet fejlődtek nálad.” A sportoló a következő asszót - az elődöntőt - már nem tudta befejezni sérülés miatt. A sportpszichológiai gyakorlati tapasztalatok alapján az ilyen szemlélet a kívánt cél elérése - a bizonyítani akarás általi magas szintű teljesítmény helyett inkább magas fokú teljesítményszorongást, alacsony vagy eredményesség függvényében szélsőségesen váltakozó önbizalmat, csökkenő kreativitást, illetve kudarckerülő attitűdöt eredményez. Nem beszélve arról, hogy a külső motiváció hangsúlyozása miatt a külső tényezők jobban befolyásolják a motivációt, ezért az ezek alakulása szerint ingadozhat. 
Egyre több szakember igyekszik a fentivel ellentétes szemléletben dolgozni, amelynek azt a nevet adhatnánk, hogy „élvezd, amit csinálsz és teljesedj ki benne”. Ilyen szemléletet közvetít például a labdarúgásban a FUNino program (Wein 2013). A fejlődés és kiteljesedés szemléletű képzés a sportolók érdeklődésére és erősségeire alapoz. Támogatja a kezdeményezést és az önállóságot. A sporthelyzetekben a problémák hangsúlyozása helyett a játékot és a kihívások élvezetét helyezi előtérbe. Az ebben a szemléletben történő képződés a tevékenység szeretete, az érdeklődés és az öröm által stabilabb, belső motivációt tarthat fenn. Továbbá erősítheti az önbizalmat, kedvező hatással lehet a kreativitásra és a kudarcokból való felépülésre.

\section{Fejlödésszemlélet és teljesitményszemlélet}

A mentális felkészítés, illetve a pszichológiai támogatás szükségszerűségét - már az utánpótlás-korosztályban is - egyre gyakrabban hangsúlyozzák a sportszakemberek. Legtöbb esetben az edzők vagy szülők elvárása a sportpszichológustól a sportoló teljesítményének növelése. Ebben a szemléletben fontos a társas környezet azon elvárása, hogy a sportoló jól teljesítsen. A pszichológia pedig a fizikai felkészítés mellett egy eszköz a teljesítmény fokozására. Egy professzionális sportcsapatnál explicite azzal a céllal alkalmaznak sportpszichológust, hogy az addigi teljesítmény javuljon, ezáltal a csapat eredményeiben és gazdaságilag is sikeresebbé váljon. A fontos szociális környezetből áradó teljesítményelvárás ugyanakkor nemcsak a professzionális sportolóknál jelenik meg, hanem már egészen korán, az utánpótlásképzésben is.

Továbbmenve, az erôs teljesítményelvárások - társadalmi szinten - az élet minden területén érzékelhetőek. A pszichológia gyakran képtelen szemléletet váltani, és kiszolgálja a teljesítményelvárásokra épülő rendszereket. Ilyen például, ha az iskolapszichológus direktben azon dolgozik a gyermekkel, hogy javuljon az iskolai teljesítménye. Ezekben a helyzetekben hiába kap pszichológiai támogatást a tanuló, a fókuszban nem ő lesz, hanem a teljesítménye. Mondjuk, az osztályfőnök felkéri a pszichológust, hogy foglalkozzon egy diákkal, mert az utóbbi időben tiszteletlen, elmarad az órákról, és sokat romlott a teljesítménye. Itt az érettségi hamarosan, segítsen, hogy vissza tudja hozni a jegyeit. Ha a tanár elküldi a pszichológushoz a diákot, aki azonnal arról kérdezi, miért rontott, mi van az iskolával, a tanárral van-e gondja vagy valami más, esetleg kifejti, milyen fontos, hogy megoldja az iskolával kapcsolatos problémáit, akkor a pszichológus a fókuszban a teljesítményt látja. Ebben az esetben a szakember átvette a rendszer elvárásait, és ő is könnyen elvárásokat kezdhet táplálni kliense iránt. Egészen más, ha azzal kezdik a munkát, hogy mi van a gyermekkel, mik az ő céljai a pszichológiai munkával, akarja-e egyáltalán, ha igen, akkor min dolgozna. $S$ ha a kliens céljai között nem szerepel az iskolai jegyeken való változtatás, a pszichológus akkor is dolgozik vele. Ez a fajta fókusz tudja elősegíteni a minőségi pszichológiai támogatást, aminek hatására lelkileg rendeződni tud a diák, és nagyon valószínű, hogy mintegy „mellékhatásaként” elkezd jobban teljesíteni az iskolában is. A példánk első esetében tehát a fókusz magán a teljesítményen van, míg a másikban önmagán az emberen, az ő teljességén. Itt az iskola és a teljesítmény pusztán egy tényező a teljes múködés egészében. 
A versenysportban lényegéből adódóan gyakran megesik, hogy a gyermek lényének egészéroól áttevődik a fókusz a teljesítményére. A teljesítmény központi kérdéssé válik a környezet, s ennek hatására a gyerek számára is. A kis sportoló megtapasztalja, hogy eredményessége hatással van a környezetére, befolyásolja az edző és/vagy a szülők hangulatát. Erős érzelmi reakciókat tud kiváltani belőlük, legtöbbször erről beszélnek a családban, megbüntetik vagy éppen felmagasztalják a teljesítményéért. Rasquinha és mtsai. 2014-ben publikált vizsgálata szerint a versenysporttal együtt járó külső környezeti hatások révén a sportolókban perfekcionista késztetések alakulnak ki, melyek elősegítik számukra, hogy magasabb szinteken is jól teljesítsenek. A problémát az jelentheti, hogy közben a környezet gyakran nem tudja, hogy mi van a gyerekkel, mi zajlik benne, milyen kétségei, félelmei, örömei, vágyai vannak egyébként. Pedig nagyon sok példát látunk arra, hogy ha a fiatal sportoló nem bírja a megfelelés és teljesítés terhét, az megjelenik pszichés vagy fizikai tünetekben, nemritkán sérülések formájában.

A testnevelésnek - mely nem csak a versenysportot fedi le - vannak olyan explicit szemléletei, melyek túlmutatnak a teljesítményfókuszon. A testnevelés humanisztikus megközelítése például egyaránt szolgálja a diákok egészségét és egészséges életstílusának elősegítését, továbbá támogatja ôket testi és szellemi harmóniájuk kialakításában, azaz segíti őket személyes növekedésükben. Ez az irányzat a diákok szubjektív tapasztalatait, értékrendjét, motivációját és irányultságát veszi alapul. A folyamat során a tanulók tudásának, készségeinek, szokásainak és mozgásos képességeinek fejlesztése mellett komoly figyelmet kapnak személyiségvonásaik, valamint spirituális és morális jellemzőik (Capulis et al. 2013).

Felmerül a kérdés, hogy a versenysportok utánpótlás-nevelésében mennyire szükséges a teljesítményfókusz, lehet-e hatékony, ha más szemléletben történik a sportoktatás?

A gyakorlati tapasztalatok alapján a kérdéshez kapcsolódóan két, jelentősen eltérő szemlélet körvonalazódik, melyekben jelentős különbség van a fejlesztő tevékenység céljában, a siker és kudarc definíciójában, illetve a motivációban. E szemléletek meglátásunk szerint másként befolyásolják a sportbeli fejlődés és a személyiségfejlődés irányát. Az első, hagyományosabb szemléletet „teljesítményszemléletnek” nevezzük. Itt a tevékenység (edzés, versenyzés, de lehet ez más terület, például a tanulás is) célja az eredmény, a teljesítmény elérése. A sikert a jó eredmény, a győzelem, a mások által elvárt produktum (például tanulásban a jó jegy) jelenti. A kudarc az, ha nem jó az eredmény, az illetô vereséget szenved, vagy nem felel meg a mások által állított elvárásoknak. Az eredményorientáltság miatt a külső motiváció könnyen átveheti a hangsúlyt. Miután a nevelők a megerősítéseket maguk számára is az eredményben látják, a fejlesztésben a mihamarabbi eredményességre törekednek, nem pedig a hosszú távú folyamat átlátására. Továbbá megerősítéseket és büntetéseket a közvetlen eredmény alapján nyújtanak a sportolóknak, nem pedig a folyamatok elősegítése érdekében. Például egy 15 éves labdarúgókapus esetében az edző a mérkőzéseken megtiltja, hogy kockázatosabb kirúgást válasszon, mert azzal veszélyezteti a csapat sikerességét. Ezzel a kapus nem fogja tudni éles helyzetben gyakorolni a kockázatosabb megoldásokat, 
ezért a képzési folyamat végére szűkebb repertoárja lesz, mint egy másfajta képzésen átment kapusnak. A folyamat versus eredmény megerősítésére példa, ha a labdarúgóedzésen gondolkodásfejlesztő kisjátékban egy játékosnak jó meglátása van egy helyzet megoldásához, és odapasszolja a labdát a társának, aki viszont nem jól méri fel a helyzetet, akkor az akció nem lesz sikeres. Ha az edző visszajelzi a jó meglátást, akkor a folyamatot erősíti meg, azazhogy igen, helyes meglátás volt, akkor is, ha most a másik miatt nem eredményes, éljen később is vele. Ha a másik társat szidja le, netán a passzoló játékost, amiért nem sikeresen passzolt, vagy ha csak a sikeres átadásokat, az átadások nyomán született gólokat erősíti meg, akkor eredményszemléletben dolgozik. A kisjáték nem fogja elérni a célját, azaz a döntéshozatal fejlődését. A teljesítményszemlélet a fentiek miatt könnyen egysíkúvá teheti a fejlődést. A „Légy elégedetlen és akarj bizonyítani” szemlélettel kombinálva pedig egyenesen kudarckerülő attitűd kialakulásához, és az önkifejezés gátlásához vezethet.

A másik, újabban egyre népszerübbé váló szemléletet „fejlődésszemléletnek” hívjuk. Itt a tevékenység célja a fejlődés, a tudás gyarapodása, a lehetőségek kibontakoztatása. A sikert abban definiáljuk, hogy a sportoló megtett mindent a célja elérése érdekében, a verseny/edzés jó közösségi élmény volt, illetve, hogy a tevékenységben megjelent a fejlődés, a tudás gyarapodása. A kudarcot itt az jelenti, ha a sportoló nem tett meg mindent, rossz hangulatúvá vált, illetve nem élt át sikerélményt. A fejlődésszemléletben űzött sportolás lényegéből adódóan kedvez a belső motiváció fenntartásának, a szélesebb skálájú fejlődésnek és a felszabadultabb önkifejezésnek, produktivitásnak. Az intenzív, sokoldalú fejlődés, a pozitív légkör és a felszabadult önkifejezés pedig óhatatlanul teljesítményt is von maga után.

A teljesítmény- és fejlődésszemlélettel kapcsolatban felmerülhet a kérdés, hogy a különböző korosztályokban és sportszituációkban (például ovifoci és labdarúgó NB I.) élesen elválhatnak-e egymástól, s melyiknek mennyire van létjogosultsága. Anélkül, hogy alaposabban vizsgáltuk volna e kérdéseket, általános elvként fogalmazhatjuk meg, hogy minél fiatalabb korosztályról van szó, annál fontosabb lehet a fejlődésszemlélet érvényesülése.

\section{Új generáció, új kérdések, új utak a sporttehetség-gondozásban}

A Z generáció lelki és társas, kapcsolati jellemzőit olvasva a sporttehetség-fejlesztés - egyáltalán a nevelés - mindennapi gyakorlatával kapcsolatban számos kérdés és probléma merül fel, melyek megválaszolása, megoldása egyaránt kihívás a sportszakma, a pedagógia és a pszichológia számára. Az alábbiakban néhány fontos témát vetünk fel a teljesség igénye nélkül:

- Tisztelet - Hogyan vívhatja ki a nevelő a tiszteletet, ha a tisztelet már nem feltétlenül alapul a pozíción és tekintélyen?

- Figyelem - Az információs társadalomban a fiatalok más figyelmi jellemzőkkel rendelkeznek. Folyamatosan rengeteg információ árasztja el őket, a médiából 
intenzív ingerek érik a gyerekeket, melyek fejlődő idegrendszerükre igen markáns hatással vannak. A felgyorsult életvitel, a gyakran - az idegrendszeri éretlenség miatt - a feldolgozhatóságot meghaladó mennyiségú és intenzitású ingerek figyelemproblémákhoz, pszichés feszültséghez, sokszor hiperaktivitáshoz vezetnek. Kérdés, hogyan tud a sportoktatás válaszolni a megváltozott figyelmi jellemzőkre.

- Érzelmi szükségletek és fejlődés - A kielégítetlen érzelmi szükségletek, az odafigyelés hiánya egyenetlenné teheti a személyiség fejlődését. Sokszor találkozhatunk kognitív szinten nagyon érett, ugyanakkor az érzelmi érésben elmaradott fiatalokkal. Ez az éretlenség megjelent többek között érzelmi impulzivitásban, az érzelmek gátolt kifejezésében, kommunikációs és kapcsolódási problémákban. Gyakorlati szinten ezekkel kapcsolatban számos probléma jelentkezik. Például nem tudja kezelni a sportoló a kudarchelyzeteket, nem tud beilleszkedni a csapatba, vagy viselkedése negatív hatással van csapattársaira. Kérdés, hogyan tud a sporttehetség-gondozás segíteni az érzelmi érésben.

- Irányítás és fegyelmezés - Az elóbbiekból adódóan (például a figyelemproblémák, a tisztelet kérdése, az érzelmi impulzivitás) a nevelők az irányítással és fegyelmezéssel kapcsolatban is kihívások elé kerülnek.

- Motiváció - Nehéz a sportfoglalkozásoknak a sok változatos, érdekes ingerrel felvenni a versenyt. A mi kultúránkban a fiatalok számára a sport kevésbé számít kitörési lehetőségnek, mint egy fejlődő országban. Kutatási adatok szerint például a labdarúgásban azok a fiatalok jutnak magasabb szintre, akiket családjuk anyagilag, érzelmileg és időráfordítással (mérkőzésre, edzésre eljuttatás révén) egyaránt támogat (Orosz 2009). Tehát nincsenek feltétlenül rászorulva, hogy később a labdarúgásból éljenek meg. A külső motiváció ereje (kitörés, hírnév, anyagi megélhetés) ezért is korlátozottabb. A motivációban - ami igazi kihívás a nevelók számára - egyre nagyobb szerep jut a belső motivációnak, azaz a tevékenység szeretetének, a fejlődés örömének, illetve az érdeklődésnek.

- Kommunikáció - A sportoktatásban igen fontos kérdés, hogyan lehet a leghatékonyabban kommunikálni az új generációval, hogyan lehet leghatékonyabban eljuttatni hozzájuk az üzeneteket.

\section{Tudatosság a fejlódés érdekében. A tudatos edzó és tudatos sportoló eszménye}

Egyik hathatós válasz a fenti problémákra a tudatosság fejlődése lehet. A tudatos, önmagát szakmailag, pedagógiailag és emberileg fejlesztő edző, illetve a tudatos, saját fejlődésében aktív szerepet és fejlődéséért felelősséget vállaló sportoló közös munkája lehet a sporttehetség-gondozás új útja.

Egy ilyen edző-tanítvány kapcsolatban a tisztelet alapja a következő tényezőkön nyugszik:

- Hitelesség - Az edző személyiségének hitelessége, az általa nyújtott minta sokkal fontosabb, mint a szóbeli instrukciók vagy a „lelki fröccsök”. A hitelesség az általa közvetített értékek, elvárások és a cselekedetei közötti összeillésen alapszik, 
és az önismeretében gyökerezik. Például egy szorongó edző nehezen várhatja el játékosaitól, hogy ne izguljanak a mérkőzések előtt. Vagy, aki nem tesz meg mindent a saját munkájának sikeréért (például folyamatos képzéssel, edzésekre való felkészüléssel), hogyan várja el, hogy a sportolók megtegyenek mindent a közös sikerért?

- Tudás - A tudás érzékelése belülről fakadó tiszteletet vív ki a fiatalokból. A saját élethosszig tartó fejlődés, a tudás állandó gyarapítása, a nyitottság az új ismeretekre ezért is lehet nagyon fontos a sportszakemberek számára.

- Valódi odafigyelés - A fiatalok érzelmi igényeinek kielégítése, pozitív kötődést és érzelmeken alapuló lojalitást alakít ki az edzővel. Az odafigyelés, az empátia, az elfogadás, a megértés megtapasztalása emellett segíti a sportoló érzelmi érését, felnövését is.

- Kommunikáció - A Z generáció fiataljai az alá-fölé rendelt, tekintélyelvű kommunikáció helyett igénylik a kölcsönösségen alapuló, partneri kommunikációt. Például ha tiszteletet vár el tőlük a nevelő, akkor az ő kommunikációjában is tiszteletnek kell megnyilvánulni a sportolók felé, vagy, ha azt akarja, hogy tényleg meghallgassák a véleményét, jó, ha ő is tényleg odafigyel a gyerekek mondandójára.

A sportolók tudatosságának fokozódásában, illetve a saját fejlődésükben való aktív szerepvállalásnak az elősegítésében fontos tényező, hogy az előre megadott „konzervtudás" kritikátlan fogyasztása helyett képessé váljanak saját felismerésekre. Horn (2008, idézi Erickson et al. 2011) és Kahan (1999) szerint az egyoldalú edzői kommunikáció passziv, befogadó féllé alakítja a sportolót, ezáltal meggátolva, hogy a versenyző önmaga is tevékenyen részt vehessen önnön fejlesztésében. Ezzel szemben a többoldalú (multidimenzionális) sportoló-edző kapcsolat figyelembevételén alapuló elmélet abból indul ki, hogy az edzői munka egy komplex, reciprok kölcsönhatással müködő folyamat, amely társas interakciók rendszerére épül (Bowes \& Jones 2006; Cushion et al. 2006). Néhány példa, hogyan lehet elősegíteni, hogy a sportoló tudatos, aktív és felelős résztvevője legyen a saját fejlődésének:

- Kétirányú kommunikáció - Például videóelemzésnél az edző ahelyett, hogy elmondja, melyik helyzetben mit s hogyan „kellett volna” csinálni, megkérdezi a játékosok véleményét az adott szituációkról. Itt fontos, hogy ha nem az általa elvárt választ kapja, akkor a ,jó” válasz megadása helyett tovább kérdez, és megpróbálja megérteni, a játékos miként látja a szituációt, mit gondol másként, helytelenül, vagy esetleg mit nem ért a játékhelyzetben. Ezzel segíti, hogy a sportolók a helyzet aktív résztvevőiként önmaguk jöjjenek rá a megoldásra.

- Rávezető kérdezés - A szakember irányított kérdéseinek segítségével vezeti rá a sportolókat a megfelelő megoldásra. Például a labdarúgóedző megkérdezi a játékosokat hogy kinek kell a másik mozgására figyelnie. A szélrôl a kapu elé beadó játékosnak, vagy a középen érkező csatárnak? Ha a játékosok nem tudják a 
választ, vagy a csapatban nem egyöntetú a vélemény, az edző egy hozzájuk közel álló, életszerủ példát hozva megkérdezi: Ibrahimovics figyeli, hová fut a szélső, vagy a szélső figyeli, hogyan helyezkedik Ibrahimovics?

- Aktív bevonás, felelősség átadása - Erre jó példa lehet a pihenés, regeneráció szükségességének eldöntése. Képzeljünk el két 15 éves utánpótlás-sportolót. Mindketten középiskolások, ugyanabban a sportágban versenyeznek, a versenyszezon, és egyben a tanév végén vannak. Egyikük 4-es 5-ös tanuló egy erős gimnáziumban, a szülei nagy elvárásokat támasztanak vele szemben mind a sporttal, mind az iskolai teljesítményével kapcsolatban. Ô nagyon szeretne megfelelni az elvárásoknak. Szeretne jól teljesíteni mind a sportban, mind az iskolában. A gimnáziumban a tanárok is nagy követelményeket támasztanak, az utolsó hetekben naponta íratnak témazárókat. A sportoló edzés után még mindennap készül a témazárókra, s izgul a jegyei miatt. A másik versenyző egy átlagos középiskolában jó tanuló. Az iskolában és a sportban sem támasztanak elé nagy elvárásokat, de egyébként is jó eredményei vannak, és könnyedén tudja teljesíteni az iskolai követelményeket. Mindketten a szezon utolsó versenyeire készülnek az elkövetkező három hétben. Az edző kívülről annyit lát, hogy mindketten ott vannak minden edzésen, keményen készülnek, s tudja, hogy az iskolában is jól teljesítenek. Ha nincs kialakított rutinjuk arra a szituációra, amikor a sportoló jelzi, hogy mentálisan fáradt, és pihenésre van szüksége, akkor könnyen megeshet, hogy az első sportoló túlzottan fáradtan, jóval kevesebb energiával fog versenyezni, mint a másik, s emiatt teljesítménye alatta marad képességeinek. Pedig lehetséges, hogy elég lenne néhány edzést vagy egy hétvégi versenyt kihagyni a jobb teljesítmény érdekében.

- Eredmény értékelése helyett a folyamat visszajelzése - Az eredménytelenség miatti negatív kritika, hibáztatás, becsmérlés inkább a kudarckerülő attitűdöt erősíti a sportolókban, ahelyett, hogy hozzájárulna ahhoz, hogy a fejlődésüket segítő tanulságokat tudjanak levonni a helyzetből. Az információ, amit vissza tudnak forgatni a saját fejlődésükbe, az azon dolgok konkrét visszajelzése, megerősítése, amelyeket jól csináltak, és amelyekben fejlődtek, továbbá figyelmük felhívása azon hibákra, amelyek korrigálása aktuálisan prioritást élvez.

\section{Sporttehetség-fejlesztés integratív szemléletben}

A sporttehetség-gondozás integratív szemléletủ megközelítése (Orosz 2009; Orosz, Mező 2015) szerint a fejlődés párhuzamosan több szinten zajlik. A fizikai képességek kibontakozásában szerepet játszanak személyes (perszonális), társas (interperszonális) és személyen túlmutató (transzperszonális) tényezők is. Személyes szinten a fejlődés fizikai, érzelmi, kognitív és spirituális síkon egyaránt zajlik (2. ábra). 


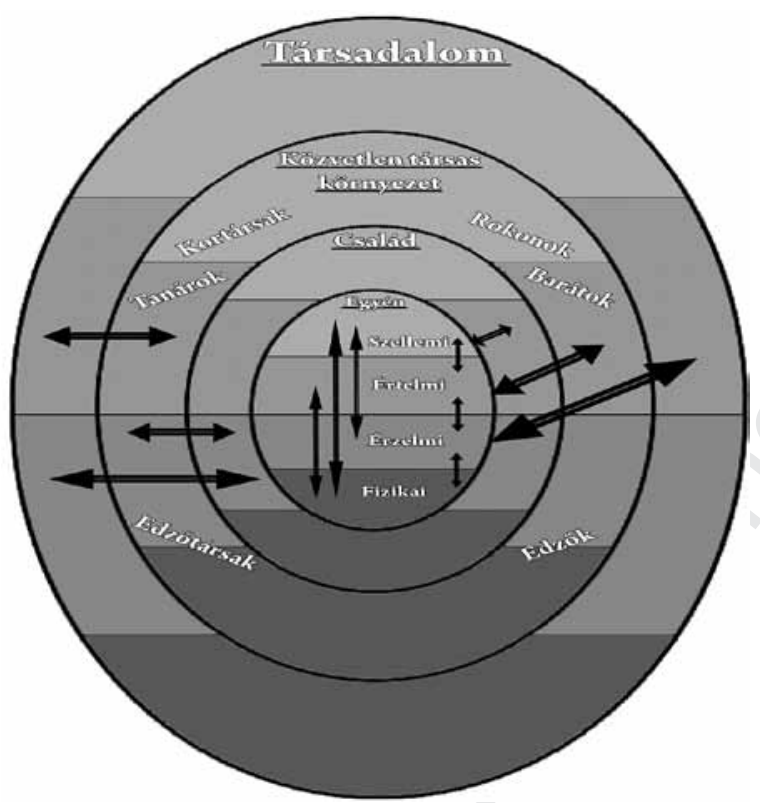

2. ábra. A sporttehetség-gondozás integratív szemlélete

(Orosz \& Bíró 2009: 24)

Vannak a sporttehetség szempontjából különösen fontos tényezők. Ilyenek például fizikai szinten az adottságok, érzelmi szinten a szorongás, kognitív szinten a figyelem, spirituális szinten a sorsfaktor, társas szinten az edző stb. Ezek a tényezők egymással kölcsönhatásban vannak, s a tehetség kibontakozását vagy elvesztését nem feltétlenül egy-egy összetevő hatásának tulajdonítjuk, hanem a tényezők dinamikus összjátékának. Az integratív szemlélet ezért fontosnak tartja, hogy holisztikusan közelítsünk a tehetséggondozáshoz. Előnyben részesíti a párhuzamosan több szinten zajló fejlesztést, melynek során a fizikai tényezőkön túli összetevőkkel is tudatosan dolgoznak. Továbbá az egyén fejlődése mellett a rendszerbeli kölcsönhatások, valamint a rendszer egészének fejlődése is központi jelentőségű. A Debreceni Labdarúgó Akadémián például 2015 óta az integratív szemlélet adja a hátteret a tehetséggondozó munkához. A játékosok fizikai képzése mellett többek között szerepet kap a csoportos mentális fejlesztés, az egyéni pszichológiai támogatás, a szülőkkel való pszichológiai munka, a korrepetálás, az iskolával való aktív kapcsolattartás és az edzők továbbképzése is.

A Tehetséghidak program sporttehetségtábora a tehetséggondozás integratív szemléletében lett kialakítva és megvalósítva. A Tehetséghidak program 2011 és 2014 között valósult meg a Magyar Nemzeti Tehetségprogram keretein belül. A sporttáborban 16 év feletti sportoló tehetségek vettek részt. Egyéni és csapatsportokból is voltak résztvevők. A sporttábor mottója a „Tudatosság és fejlődés” volt, célja pedig támogatni a sportoló tehetségek tudatosságának fejlődését személyes, interperszonális 
és transzperszonális szinten egyaránt. A tudatosság fejlesztését a következő területeken tüztük ki célul:

- Testtudatosság

- Tudatosság a mozgásban

- Tudatosság a táplálkozásban

- Érzelmek tudatosítása és kezelése

- Gondolkodás tudatossága

- Tudatosság a társas kapcsolatokban (kommunikáció, empátia, értő figyelem)

- Annak tudatosítása, hogy valami nálunk nagyobb, transzcendens egész részei vagyunk

- Jelentudatosság (mindfulness)

A táborban különböző programokban dolgoztuk fel a fenti témákat. A tábori programok és céljaik az 1. táblázatban olvashatóak:

1. táblázat. A Tehetséghidak sporttábor programjai és céljaik

\begin{tabular}{|c|c|}
\hline Tábori program & A program célja \\
\hline Bevezető interaktív előadás & $\begin{array}{l}\text { A tudatosság és a saját fejlődésért való felelősség- } \\
\text { vállalás szerepének megértése a lehetőségek kibon- } \\
\text { takoztatásában }\end{array}$ \\
\hline Beszélgetés olimpiai bajnokkal & Inspiráció, motiváció \\
\hline Freestyle bemutató és közös játék & Inspiráció, motiváció \\
\hline Közösségépítő foglalkozás & $\begin{array}{l}\text { Támogató közösség kialakítása, kommunikáció, } \\
\text { társas készségek fejlesztése }\end{array}$ \\
\hline Egyéni pszichológiai konzultáció & $\begin{array}{l}\text { Önismeret, tudatosság fejlesztése, egyéni elakadá- } \\
\text { sokban való támogatás }\end{array}$ \\
\hline Csoportos pszichológiai foglalkozások & $\begin{array}{l}\text { Önismeret, énkép, testkép, stresszkezelés, kommu- } \\
\text { nikáció témáinak feldolgozása }\end{array}$ \\
\hline Tai chi & $\begin{array}{l}\text { Jelentudatosság gyakorlása, testtudatosság, tudatos- } \\
\text { ság a mozgásban, test és tudat egysége, figyelem } \\
\text { fejlesztése }\end{array}$ \\
\hline Mediball & $\begin{array}{l}\text { Jelentudatosság gyakorlása, testtudatosság, tudatos- } \\
\text { ság a mozgásban, test és tudat egysége, figyelem } \\
\text { fejlesztése }\end{array}$ \\
\hline Jóga & $\begin{array}{l}\text { Jelentudatosság gyakorlása, testtudatosság, tudatos- } \\
\text { ság a mozgásban, test és tudat egysége, figyelem } \\
\text { fejlesztése }\end{array}$ \\
\hline Interaktív beszélgetés sportorvos dietetikussal & Tudatosság a táplálkozásban \\
\hline Jelentudatos étkezés & $\begin{array}{l}\text { Tudatosság a táplálkozásban, kölcsönösen függő léte- } \\
\text { zés megtapasztalása, jelentudatosság gyakorlása }\end{array}$ \\
\hline Lovaglás & Kapcsolat a természettel, kiegészítő sport \\
\hline Kirándulás & Lazítás, feltöltődés, kapcsolat a természettel \\
\hline Kalandpark & Lazítás, feltöltődés \\
\hline Játék & Lazítás, feltöltődés \\
\hline
\end{tabular}


A táborhoz kapcsolódóan nem végeztünk tudományos hatásvizsgálatot. A továbbiakban mindenképpen érdemes lenne hasonló programokat a sporttehetség-gondozásba integrálni, és ezek nyomon követéses vizsgálatát megvalósítani.

\section{Összegzés}

Írásunkban a sportot tágabb összefüggésbe helyezve pedagógiai-pszichológiai szemszögből tárgyaltuk a rendszerek összetett fejlődésével járó, szükséges változásokat a sporttehetség-gondozásban. Pszichológiai elméletek hátterével mutattuk be a rendszerek komplex fejlődését, kiemelve a különböző generációk pszichológiai és társas viselkedésbeli eltéréseit. Abból indultunk ki, hogy ebben a több szinten párhuzamosan zajló, összetett fejlődési folyamatban a pedagógiai-pszichológiai szemlélet - az új generációk jellemzőinek megfelelően - szintén folyamatos változást, fejlődést igényel. A bemutatott elméletek és gyakorlati tapasztalataink az integratív, fejlődés és kiteljesedés szemléletű, holisztikus sporttehetség-gondozást támogatják. Az ilyen szemléletű tehetséggondozásban kulcstényező a tudatosság foka. A siker záloga tehát az lehet, hogy milyen mértékben képes az egyén és maga a rendszer is párhuzamosan több szinten, egyre tudatosabb irányba fejlődni.

\section{Hivatkozott irodalom}

- Akçayir, M., Dündar, H. \& Akçayir, G. (2016). What makes you a digital native? Is it enough to be born after 1980? Computer sin Human Behaviour, (60), 435-440.

- Baillie, P. H. F. (1993). Understanding retairement from sports. The Counselling Psychologist, 21 (3), 399-410.

- Baumann S. (2006). Csapatpszichológia. Módszerek és technikák. Pécs, Dialóg Campus.

- Bowes, I., \& Jones, R. L. (2006). Working at the edge of chaos: understanding coaching as a complex, interpersonal system. The Sport Psychologist, 20, 235-245.

- Capulis, S., Dombrovskis, V. \& Gueva, S. (2013). Karate-Do as a Means to Implement Humanistic Approach in Sports Education. Procedia - Social and Behavioral Sciences, (112), 141-146.

- Carter, B. \& McGoldrick, M. (1989). The changing family life cycle: A framework for family therapy. Boston, MA, Allyn \& Bacon.

- Copaci, I. A. \& Rusu, A. S. (2015). A Profile Outline of Higher Education E-Tutoring Programs for the Digital-Native Student - Literature Review. Procedia - Social and Behavioural Sciences, (209), 145-153.

- Coupland, D. (2007). X generáció. Budapest, Európa Kiadó. 
- Cushion, C. J. \& Jones, R. L. (2001). A systematic observation of professional toplevel youth soccer coaches. Journal of Sport Behavior, 24, 354-376.

- Csepeli Gy. (2003): Régi és új digitális generáció. Élet és tudomány, 45. Forrás: http://www.csepeli.hu/pub/2003/csepeli_et_2003_45.pdf. Utolsó letöltés: 2016. 06.12.

- Erickson, K., Côte,J., Hollenstein, T. \& Deakin,J. (2011). Examining coach-athlete interactions using state space grids: An observation analysis in competitive youth sport. Psychology of Sport and Exercise, (12), 645-654.

- Erikson, H. E. (2002). Gyermekkor és társadalom. Budapest, Osiris.

- Gursoy, D., Geng-Qing-Chi, C. \& Karadag, E. (2013). Generational differences in work values and attitudes among frontline and service contact employes. International Journal of Hospitality Management, (32), 40-48.

- Kahan, D. (1999). Coaching behaviour: a review of the systematic observation research literature. Applied Research in Coaching and Athletics Annual, 14, 17-58.

- Kurimay T. (szerk.) (2004). Családterápia és családkonzultáció. Európai távoktatási tankönyv. Budapest, Coincidencia.

- Lochbaum, M. \& Gottardy, J. (2015). A meta-analytic review of the approachavoidance achievement goals and performance relationships in the sport psychology literature. Journal of Sport and Health Science, 4, 164-173.

- McCrindle, M. \& Wolfinger, E. (2010). Az x y z ábécéje. Korunk, 3, 13-18.

- Nobel, S. M., Haytko, D. L. \& Phillips, J. (2009). What drives college-age Generation Y consumers? Journal of Business Research, 62 (6), 617-628.

- Orosz R. (2009). A labdarúgó tehetség kibontakoztatását befolyásoló pszichológiai tényezők vizsgálata. PhD-értekezés. Debreceni Egyetem BTK, HTDI Pszichológia Doktori Program.

- Orosz R. \& Bíró Zs. (2009). A siker kapujában. A labdarúgó tehetség pszichológiája. Debrecen, Kék Bolygó Tehetségpont.

- Orosz, R. \& Mezo, F. (2015). Psychological factors in the development of footballtalent from the perspective of an integrative sport-talent model. Journal for the Education of Gifted Young Scientists, 3 (1), 58-76. DOI: http://dx.doi.org/10.17478/ JEGYS.2015112018.

- Pais E. R. (2013). Alapvetések a Z generáció tudomány-kommunikációjához. Tanulmány, Pécsi Tudományegyetem. Forrás: http://www.zgeneracio.hu/getDocument/541. Utolsó letöltés: 2016. 06.13.

- Prensky, M. (2001). Digital Natives, Digital Immigrants Part 1. On the Horizon, (9), $1-6$.

- Rasquinha, A., Dunn, J. G., H. \& Dunn, J. C. (2014). Relationships between perfectionistic strivings, perfectionistic concerns, and competitive sport level. Psychology of Sport and Exercise, (15), 659-667.

- Strauss, W. \& Howe, N. (1991). Generations: The History of America's Future, 1584 to 2069. New York, William Morrow. 
- Tari A. (2011). Z generáció. Budapest, Tericum Kiadó.

- Tulgan, B. (2004). Trends point to a dramatic generational shift in the future workplace. Employment Relations Today, 30 (4), 23-31.

- Verčič, A. T. \& Verčič, D. (2013). Digital natives and social media. Public Relations Review, (39), 600-602.

- Wein, H. (2013). Funino. Egy csodálatos játék gyerekeknek. Budapest, Magyar Labdarúgó Szövetség. 


\title{
A sporttehetség-gondozás jogszabályi környezete - a sportakadémiák Magyarországon
}

\begin{abstract}
Absztrakt
Jelen tanulmány fô célkitűzése, hogy megvizsgálja a magyarországi labdarúgó akadémiák jogszabályi környezetét, illetve az internetes honlapjain feltüntetett dokumentumok elérhetőségét, különös tekintettel az alapító okirat meglétére. Emellett célkitűzésünk még, hogy a Magyar Labdarúgó Szövetség (a továbbiakban: MLSZ) akadémiákhoz való viszonyulását is elemezzük abból az aspektusból, hogy mely, számunkra is elérhető dokumentummal tesznek utalást az akadémiák múködésére, szabályozására.

Kérdésünk, hogy maga az MLSZ tesz-e utalást az akadémiák jogi beágyazottságára, amennyiben igen, akkor milyen módon teszi ezt meg. Kutatási kérdés továbbá, hogy a labdarúgó akadémiák milyen minőségű honlapokkal rendelkeznek, vannak-e számottevő különbségek az egyes akadémiák között - különös tekintettel a toborzás kérdésére.

A vizsgálathoz dokumentumelemzést végeztünk, melynek során áttekintettük a labdarúgó akadémiák honlapjait, illetve az MLSZ elérhető dokumentumait és a köznevelési törvényt.

A kutatási eredményeink alapján elmondható, hogy igen kevés azon akadémiák száma, amelyek alapító okirataikat elérhetővé, olvashatóvá teszik, emellett az MLSZ is csupán egy dokumentumban tesz utalást az akadémiákra. Az akadémiák honlapjait tekintve is nagy különbségeket tapasztaltunk az elemzés során, némely akadémia saját honlappal sem rendelkezik.
\end{abstract}

\section{A kutatás problematikájának azonosítása}

Napjainkban a labdarúgó akadémiákkal ${ }^{1}$ kapcsolatban a hazai közvélemény legalábbis megosztott. Az akadémiák létét nem igazolják sportszakmai sikerek, ellenben a kívülálló megfigyelők számára visszás jelenségek a hatalmas infrastrukturális fejlesztések és a komoly pénzek, melyek köz- és magánforrásokból is megjelennek a labdarúgó akadémiák hátterében. Ezek az aggályok az akadémiák egyébként nagyon is könnyen elfogadható célkitűzéseit, a sporttehetségek felfedezését és felkarolását, a tehetséges

1 A következőkben megállapításainkat elsősorban a labdarúgó akadémiákra vonatkoztatjuk, de a legtöbb megállapításunk érvényes más sportágak akadémiáira is. 
fiatal labdarúgók karrierjének elősegítését is kétségessé teszik. Ha tisztázni szeretnénk ezeket az ellenérzéseket, ha kíváncsiak vagyunk ezek megalapozottságára, érdemes megvizsgálnunk a labdarúgó akadémiák szervezeti és múködési formáit, jogszabályi környezetüket - hiszen éppen ezek tehetnék átláthatóvá és tisztává viszonyaikat, megnyugtatva a laikus szemlélóket arról, hogy ezeken az utánpótlás-nevelő akadémiákon felelős munka, eredmény- és célorientált, racionálisan szervezett tevékenység folyik, és nem pazarló, esetleg legalitására nézve bizonytalan pénzmozgások elfedésére szolgáló szervezetek.

A szabályozás hiányos volta, a szervezeti és fenntartói sokszínűség ugyanis rengeteg kérdést vet fel. Felvetôdhet bennünk: mik a valódi céljai az akadémiai rendszernek? Miképpen definiálódnak jogszabályi háttér híján a szervezeti és felhasználói elvárások, a teljesítendő kötelezettségek? A minőségbiztosítási és múködési normák miképpen teljesülnek pontosan tisztázott jogszabályi keretek nélkül? Ha ez hiányzik, akkor a sportszakmai mérőszámok maradnak kizárólagos dimenziói az akadémiák múködési minőségbiztosításának? Pedig ez a mező kötelezettségekkel jócskán átszőtt és nem egyszerú (ne feledjük: tankötelezett, nem felnőtt korú fiatalok, sőt gyerekek nevelésérôl lévén szó): a pedagógiai dimenziók el nem hanyagolhatóak. Azonban ha dominánssá válnak a sportszakmai értékelési dimenziók, és csak ezek határozzák meg a múködést, minden más - akár nevelési, pedagógiai érdek - legjobb esetben érdektelen, kedvezőtlenebb esetben hátráltató, kontraproduktív összetevőként nyer értelmet. Ez az elv pedig olyan gyakorlatokat alapozhat meg, amely hátrányosan hat például a gyerekekkel foglalkozó felnőttek kiválogatásának szempontjára, melyek között a pedagógiai képzettség vagy a nevelési gyakorlat könnyen maradhat alul a sportszakmai képzettséggel, minősítettséggel szemben.

Ez már csak azért is lényeges, mert a minőségbiztosítási elvek és gyakorlat mellett az ellenőrzés kérdése is felmerülhet, hiszen az akadémiák csak sportszakmai tevékenységüket tekintik olyan tevékenységnek, melyet időrôl időre lehet és kell is átvilágításoknak alávetni (pl. az MLSZ akkreditációi, a Double Pass vagy egyéb auditok), ${ }^{2}$ de nem megoldott, sőt igazából meg sem tárgyalt kérdés, hogy az akadémiák nevelési, pedagógiai dimenziói miféle ellenőrzésnek, átvilágításnak volnának alávethetők. Pedig ez korántsem elhanyagolható dimenzió, hiszen az akadémisták elsődleges életvilága az akadémiák által meghatározott, idejük túlnyomóan nagy részét töltik az akadémia által dominált szociális térben, az akadémiák által meghatározott értékrendet és feladatokat követve, az akadémiák munkatársainak felügyelete alatt. Milyen ez az életvilág pedagógiai szempontból? Milyen ez a felügyelet pedagógiai minőségére nézve? Mi a leginkább múködőképes és a diákok érdekeit legnagyobb mértékben szavatoló kapcsolat az akadémiák és a közoktatás intézményrendszere között? Helyes vagy elfogadható

2 A Double Pass 2013-14-es vizsgálatának fó indikátorai voltak: 1. Stratégia és pénzügyi tervezés. 2. Szervezeti struktúra. 3. Kiválasztás és fejlesztés, képzés. 4. A sportolói és szociális támogatás. 5. Az akadémiai HR. 6. Kommunikáció és együttmúködés. 7. Infrastruktúra, felszereltség. 8. Hatékonyság: beválás (feladás), lehetőségek és korlátok. Forrás: http://www.mlsz.hu/wp-content/uploads/2014/06/ MLSZ-AUDIT_140616.pdf (valamennyi internetes forrás letöltése: 2016. 06.14.). 
gyakorlat-e, ha az akadémiák maguk lépnek intézményfenntartói szerepbe, így saját iskolájukban oldják meg a hallgatók tanulmányi kötelezettségének teljesítését, majd szakképzését? De ha már itt tartunk - érdemes-e olyan fenntartó által múködtetett oktatási intézménytől színvonalas pedagógiai munkát várnunk, amely a sportszakmai elvek elsődlegességén alapuló akadémiai rendszer elvei által meghatározott? Valóban az akadémisták érdekeit szolgálja-e egy olyan pedagógiai erőtér, mely saját elveit eleve másodlagosnak tekinti a sportszakmai elvekkel szemben? Van-e sajátos elönye annak, ha a fenntartói körben oktatási intézmény, esetleg egyetem vállal szerepet, mint a debreceni akadémia esetében? Járhat-e ez a múködés kézzelfogható előnyökkel az akadémisták számára? Sajnálatos módon a jogszabályi háttér adós marad a pontos válaszokat lehetővé tévő meghatározásokkal.

A problémák általunk azonosított két gyökere mélyen összefügg egymással. Ezek közül az első az akadémiák szervezeti felépítésében mutatkozó sokszínűség. Ma ugyanis annak lehetünk tanúi, hogy többféle szervezeti formában is múködhetnek: léteznek alapítványi akadémiák, ezek között olyanok is, amelyeket magán- (természetes) személy alapított és olyanok is, amelyet jogi személy, például vállalat. Léteznek olyan akadémiák, melyek szorosan köthetôk egyes sportklubokhoz, gyakran alapítójuk egy konkrét sportegyesület, és ezek mellett kisebb számban ugyan, de nem elhanyagolható jelentőséggel léteznek még szövetségi (sportági) akadémiák is, ${ }^{3}$ illetve léteznek olyan akadémiák, melyek nem alapítványi formában múködnek, hanem a gazdálkodó szervezetektől megszokott formában üzemelnek. A másik probléma szorosan kapcsolódik a szervezeti rendben megfigyelhetô sokféleséghez. Annak lehetünk ugyanis tanúi, hogy akár valamilyen alapítványi, akár korlátolt felelősségú társasági formában múködik az akadémia, az eltérés nem teszi lehetetlenné azt, hogy a professzionális sportutánpótlás-képzés konkrét feladatát a közhasznúság múködési jellegével egészítsék ki, szélesre tárva ezzel a finanszírozási források lehetséges spektrumát, rákényszerülve ugyanakkor másodlagos tevékenységi kötelezettségek vállalására. Ezzel azonban egyrészt olyan források kerülnek az akadémiákhoz, melyek bevonása széles körú figyelmet kelthet és igen érzékeny reakciókat szülhet, másrészt az ezzel járó vállalások kérdésessé teszik a szervezetek múködésének célracionalitását, vagy megkérdőjelezik másodlagos céljaik realitását.

\section{Módszerek}

A vizsgálathoz dokumentumelemzést végeztünk, mely során áttekintettük a labdarúgó akadémiák honlapjait, illetve az MLSZ elérhető dokumentumait és a köznevelési törvényt. Összesen 18 labdarúgó akadémia honlapja került elemzés alá, a mintába azok az akadémiák kerültek, amelyek jelenleg fellelhetőek Magyarországon.

3 A szövetségi forma a labdarúgásban nem, de egyéb sportágak esetében jellemző, így a kézilabda vagy a kosárlabda esetében. 


\section{A probléma kifejtése - példák az egyes esetekre}

Az általunk közelebbről megvizsgált labdarúgó akadémiák közül a legszélesebb körben ismert alapítványi formában múködő akadémia a felcsúti Puskás Ferenc Labdarúgó Akadémia, egy magánszemély, a közismerten labdarúgás-kedvelő politikus, Orbán Viktor kezdeményezésére létrehozott alapítvány fenntartásában múködik. De ehhez az alapítványi típushoz tartozik például a szombathelyi Illés Akadémia (Illés Sport Alapítvány) is, ami annak jó példája, hogy korábban ismert hivatásos játékos az aktív labdarúgó karrier végeztével kezdeményezi ilyen típusú intézmény alapítását, szerepet vállalva az utánpótlásképzés területén. A fentiekkel ellentétes példa a szegedi KÉSZ Labdarúgó Akadémia, amely ezzel szemben a KÉSZ-csoport, Magyarország egyik legnagyobb építooipari vállalkozásának alapítványa. Az alapítványi forma választása esetén az alapító joga és egyben feladata, hogy meghatározza az alapítvány által követendő célt. ${ }^{4}$ Általában azt figyelhetjük meg, hogy a közhasznúság elvének betartása miatt a célt nem konkrét, jól meghatározott formában, hanem általános megfogalmazásban határozzák meg. Például a KÉSZ-akadémia a következő formában: „Az Alapitó a fiatal generációk tömeges egészséges életmódra nevelése céljából, valamint a tehetséges fiatal labdarúgó játékosok kiválasz tása és tehetséggondozása révén a magyar labdarúgó és sportélet felvirágoztatása érdekében alapitványt hoz létre."

Tevékenységi körüket és vállalt feladataikat más labdarúgó akadémiák is igyekeznek úgy definiálni, hogy ne lehessen ôket a szúken értelmezett hivatásos vagy élsport tevékenységi köréhez csatolni, hanem a tehetséggondozáson és a sport és egészségmegőrző tevékenységeken keresztül széles társadalmi csoportok jöhessenek szóba potenciális klienseikként. Különösen így van ez azoknál az akadémiáknál, melyeknél valamely önkormányzat is az alapítók vagy az üzemeltetők között van, ilyen esetben ugyanis az önkormányzat közszolgáltatói feladatainak egy részét is átruházza az akadémiákra, ezzel mintegy szavatolva tevékenységük közhasznú voltát. Ez azonban felveti annak kérdését, ha komolyan veszik a közhasznú célokat, nem aprózzák-e fel túlzottan az erőforrásokat - nem téríti-e ez el elsődleges céljától a labdarúgó akadémiákat felhígitva a tevékenységeik rendszerét. Sőt a célok többszöröződésével egy a mi szempontunkból még komolyabb probléma is jelentkezik: a pedagógiai szempontok így látszólag még kevésbé érvényesülnek, a célok között elkallódnak, hátrasorolódnak, sôt néha a fogalmak maguk is keverednek.

Ha a célrendszer meghatározásánál nagy hangsúly kerül a közhasznúságra, még inkább így van ez a tevékenységrendszer meghatározásakor, tekintetbe véve az 1997. évi CLVI. A közhasznú szervezetekről szóló törvény 26. § c) pontjában felsoroltakat, amely jogszabályi hely az akadémiák leggyakoribb hivatkozási pontja. Ez azért érdekes, mert a törvény megfogalmazása szerint a közérdekű tevékenységek skálája

${ }^{4}$ A PTK 74/A § alapján alapító lehet magánszemély és jogi személy. A labdarúgó akadémiákat múködtető alapítványok között, mint láthattuk példáinkon, mindkettốre találunk példát.

${ }_{5}$ www.keszakademia.hu/Download2/4/ 
meglehetősen széles, a magukat közhasznúként definiáló szervezetek könnyen találják meg a profiljukhoz legközelebbi dimenziót. ${ }^{6}$ Ennek megfelelően történik meg az általános megfogalmazású céloknak a konkretizálása az imént példaként említett KÉSZakadémia esetében, ahol a következő rendet követi az akadémia tevékenységi köreinek felsorolása: ${ }^{7}$

1. Az általános iskolás gyerekek egészséges életmódra, mozgásszeretetre nevelése rendszeres tömegsport jellegú labdarúgó oktatással.

2. Tehetséges játékosok kiválasztása, helyi és regionális labdarúgó tornák szervezése során.

3. A kiválasztott fiatal labdarúgók tehetséggondozása, valamint részükre rendszeres anyagi és szakmai támogatás nyújtása.

4. Mindezek által Szeged város, a Dél-Alföld régió, és a Nemzet labdarúgó életének támogatása, felvirágoztatása.

További példa gyanánt bemutatjuk, a győri alapítványi akadémián hogyan nyilatkoznak: Az Alapitvány céljainak megvalósitása érdekében a közhasznú szervezetekról szóló 1997. évi CLVI. törvény 26. \$-ának c) pontja alapján az alábbi közhasznú tevékenységeket végzi:

- nevelés és oktatás, képességfejlesztés, ismeretterjesztés;

- kulturális tevékenység;

- gyermek- és iffúságvédelem, gyermek- és iffúsági érdekképviselet;

- sport, a munkaviszonyban és a polgári jogviszony keretében megbizás alapján folytatott sporttevékenység kivételével;

- egészségmegörzés, betegségmegelózés, gyógyitó-, egészségügyi rehabilitációs tevékenység,

- rehabilitációs foglalkozás.

A közhasznú szolgáltatások bárki számára hozzáférhetők. ${ }^{8}$

- Célunk, hogy évröl évre egyre több fiatal, tehetséges sportoló kerüljön ki az intézmény falai közül, akik a sport mellett az élet számos területén sikeresen megállják a helyüket.

- Célunk, hogy a legmagasabb szinten biztositsuk a sportoló fiatalok iskolai és sportbeli kötelezettségeinek összehangolását.

6 Az 1997. évi CLVI. tv. 26. § (c) pontja szerint: 1. egészségmegôrzés, betegségmegelózés, gyógyitó-, egészségügyi rehabilitációs tevékenység, 2. szociális tevékenység, családsegités, idöskorúak gondozása, 3. tudományos tevékenység, kutatás, 4. nevelés és oktatás, képességfejlesztés, ismeretterjesztés, 5. kulturális tevékenység, 6. kulturális örökség megóvása, 7. müemlékvédelem, 8. természetvédelem, állatvédelem, 9. környezetvédelem, 10. gyermek-és ifuúságvédelem, gyermek-és iffúsági érdekképviselet, 11. hátrányos helyzetú csoportok társadalmi esélyegyenlöségének elösegitése, 12. emberi és állampolgári jogok védelme, 13. a magyarországi nemzeti és etnikai kisebbségekkel, valamint a határon tüli magyarsággal kapcsolatos tevékenység, 14. sport, a munkaviszonyban és a polgári jogi jogviszony keretében megbizás alapján folytatott sporttevékenység kivételével, 15. közrend és közlekedésbiztonság védelme, önkéntes tüzoltás, mentés, katasztrófaelháritás, 16. fogyasztóvédelem, 17. rehabilitációs foglalkoztatás, 18. munkaeröpiacon hátrányos helyzetü rétegek képzésének, foglalkoztatásának elösegitése és a kapcsolódó szolgáltatások, 19. euroatlanti integráció elósegitése, 20. közhasznú szervezetek számára biztositottcsak közhasznú szervezetek által igénybe vehetö - szolgáltatások.

7 www.keszakademia.hu/Download2/4/

8 http://www.fmla.hu/hu/fenntarto/ 
- Célunk, hogy a gyakorlati sportszakmai képzést alátámasztó, segitő elméleti képzést is nyújtsunk, és elösegitsük OKJ-s sportszakmák megszerzését.

- Célunk, hogy a magyar labdarúgás folyamatos és magas szintúu utánpótlás bázisaként tevékenykedjünk, és példaértékú müködésünkkel etalonná váljunk az országos sportutánpótlás területén. ${ }^{9}$

Fel kívánjuk itt hívni arra a figyelmet, hogy azt állítják: a közhasznú szolgáltatások mindenki számára hozzáférhetőek. De hogyan fér ez lényegi kompromisszumok nélkül össze a sportakadémiák eredeti, elitnevelési és tehetséggondozási célkitűzéseivel? A közhasznúság elvárása sokkal inkább tömegsport-orientált müködést sugall és nem profisport-orientált, a teljesítmény állandó mérésén és javításán alapuló, erősen szelektív rendszert. A Debreceni Labdarúgó Akadémia az alapítványi akadémiáktól eltérō szervezeti megoldást választott. Esetében a fenntartó a Debreceni Labdarúgó Akadémia Nonprofit Korlátolt Felelősségű Társaság társasági szerződésében definiálja magát közhasznú szervezetként. A társaság tagjai a DVSC Futball Szervező Zrt., Debrecen Megyei Jogú Város Önkormányzata és a Debreceni Egyetem. A társaság a Debrecen Megyei Jogú Város Önkormányzatával megkötött közszolgáltatási szerződés alapján lát el jogszabályban meghatározott közfeladatokat. ${ }^{10} \mathrm{~A}$ helyi önkormányzatokról szóló 2011. évi CLXXXIX. tv. 13. § 1. bekezdése alapján az önkormányzat feladatai közül a társaság átvállalja a következő feladatokat, ezzel közhasznú funkciót teljesítve:

1. Az egészséges életmód segitését célzó szolgáltatások

2. Kulturális szolgáltatások

3. Helyi közmüvelódési tevékenység támogatása

4. Sport, ifjúsági ügyek.

A sportról szóló 2004. évi I. tv. 55. § 3. bekezdése alapján a helyi önkormányzatok sporttal kapcsolatos feladatai közül vállalja, hogy:

1. segiti a sportági és iskolai területi versenyrendszerek kialakitását, illetve az e körbe tartozó sportrendezvények lebonyolitását;

2. közremüködik a sport népszerüsitésében, a mozgás gazdag életmóddal kapcsolatos sporttudományos felvilágositó tevékenység szervezésében.

A fentieken túl a társaság „együttmüködik a testneveléssel és sporttal foglalkozó állami, önkormányzati szervekkel, társadalmi szervezetekkel, különösen a nevelési-oktatási intézményekkel. A tulajdonában álló létesítmény lehetóségei szerint ellát továbbá minden olyan feladatot, amelyet a létesitóo okirata lehetövé tesz és az önkormányzat közfeladatainak ellátását szolgálja."11

9 http://www.fmla.hu/hu/kuldetes/

10 Debrecen Megyei Jogú Város Önkormányzatának Közlönye 2015/26. 2015. december 17. I. kötet.

11 Debrecen Megyei Jogú Város Önkormányzatának Közlönye 2015/26. 2015. december 17. I. kötet 3930. oldal. 
Közös vonása tehát a valamilyen alapítványi és az egyéb formában múködő labdarúgó akadémiáknak az, hogy működésüket közhasznú tevékenységként definiálják, és az ilyen tevékenységek vállalóit támogató jogszabályok nyújtotta lehetőségekkel élni kívánnak. Kérdés, hogy mennyiben felelnek meg az őket körülvevő társadalom valós igényeinek és elvárásainak. A hatályban lévő civil törvény három jól meghatározott dimenzió mentén kapcsolja a közhasznúság kritériumát a társadalmi támogatottság mértékéhez. ${ }^{12}$ Az első szerint a civil adózói felajánlások a két utolsó lezárt évben meg kell haladják a közhasznú civilszervezet összes bevételének két százalékát. Ehhez kapcsolódóan érdemes megjegyeznünk azt is, hogy az alapító is mutathat civil aktivitást, további adományokkal támogatva a létrehozott közhasznú alapítványa múködését. Általában a folyamatos múködést támogató adománynak ez a formája elmarad, és érdemes azt is megjegyezni, hogy az alapító felajánlás, illetve a fenntartó szervezet alaptőkéje általában hatalmas kontrasztba kerül az akadémiák működési vagyonával, támogatói pénzforgalmával. Az akadémiák bevételei ugyanis a társasági nyereségadóból, illetve különböző gazdálkodó szervezetek támogatási, esetleg szponzori szerződéseiből nagyságrendileg haladják meg az alapítók kezdeti felajánlásait. A másik dimenzió, melyben a civil törvény meg kívánja ragadni a civilszervezetek társadalmi támogatottságát, az önkéntes munkát végzők száma lehetne. A harmadik elem az összes költés mennyiségéhez viszonyított aránya a közhasznú ráfordításoknak. Ez azonban sajnos értelmezhető lehet puszta könyveléstechnikai megoldásként is. Mivel a közhasznú civilszervezeteknek beszámolójuk jóváhagyásával egy időben közhasznúsági mellékletet is kell készíteniük, ${ }^{13}$ kijelenthetjük, hogy az első és a második kritériumot az akadémiák rendre nem teljesítik. Meg kell jegyeznünk azonban, hogy megvizsgálva az akadémiák honlapjait, igen kevés esetben találtuk meg a beszámolót és a közhasznúsági mellékletet. Ha a legjobbat feltételezzük, és feltesszük, hogy az akadémiák más formában, például telephelyük hirdetőtábláján kifüggesztve teljesítik a nyilvánossággal kapcsolatos kötelezettségeiket, akkor is azt kell mondanunk, ez a gyakorlat sem segít azoknak a kétségeknek az eloszlatásában, melyek éppen működésük átláthatatlansága miatt vádolják az akadémiákat. ${ }^{14}$

12 2011. évi CLXXV. tv. az egyesülési jogról, a közhasznú jogállásról, valamint a civilszervezetek múködéséról és támogatásáról 33. § (5) szerint: Megfeleló társadalmi támogatottság mutatható ki az (1) bekezdés szerinti szervezetnél, ha az elózóo két lezárt üzleti éve vonatkozásában a következó feltételek közül legalább egy teljesül: a) a személyi jövedelemadó meghatározott részének az adózó rendelkezése szerint a szervezetnek felajánlott összegból kiutalt összeg eléri az 54. \$ szerinti bevétel nélkül számitott összes bevétel kettôs százalékát, vagy b) a közhasznú tevékenység érdekében felmerült költségek, ráforditások elérik az összes ráfordítás felét a két év átlagában, vagy c) közhasznú tevékenységének ellátását tartósan (két év átlagában) legalább tiz közérdekü önkéntes tevékenységet végzó személy segiti a közérdekü önkéntes tevékenységröl szóló 2005. évi LXXXVIII. törvénynek megfelelöen.

13 A civilszervezetek gazdálkodásáról szóló 350/2011 (XII. 30.) Korm. rendelet 44. § (1) szerint.

${ }_{14}$ Megjegyezzük, az átlátható gazdálkodás hiánya is lényeges eleme a Double Pass auditjának (www.mlsz.hu/wp-content/uploads/2014/06/MLSZ-AUDIT_140616.pdf). 


\section{A labdarúgó akadémiák elérhető honlapjai, elemzési eredmények}

A beszámolók, közhasznúsági mellékletek közzétételének hiánya mellett újabb támadási felületet adnak az akadémiák azzal, hogy nincs egységes tipológia a jogi szabályozottságuk, meghatározottságuk terén. Ezért is lényeges, hogy magukat az akadémiákat is be tudjuk sorolni valami magasabb rendú kategóriába, leginkább a pontos definiálásuk érdekében. Ha a labdarúgó akadémiák besorolására vállalkozunk, akkor a sportiskolák egyik típusaként tudjuk őket definiálni. A Lehmann László és kutatócsoportja által publikált eredmények alapján a sportiskolák két típusát, nevezetesen a közoktatási és az egyesületi típusokat lehet megkülönböztetni (Lehmann 2005). A labdarúgó akadémiákat feltérképező kutatás rávilágított arra, hogy a különböző, korábban levezényelt elemzésekben sokan sokféleképpen értelmezték a sportiskola definícióját, nem volt egységes konszenzus (Rábai 2016). Ez azt is jelentette, hogy azok a közoktatási intézmények is sportiskolai elnevezést kaphattak, amelyekben testnevelési tagozat múködött, ezek többnyire általános és középiskolaként jelentek meg (Lehmann 2003; 2005).

A labdarúgó akadémiák a nem köznevelési, azaz az egyesületi típusba tartoznak, azonban ha a jogi és egyéb szabályozottságukat vesszük górcső alá, akkor jelentős hiányosságokba ütközhetünk (Lehmann 2011). Ezek szintén kérdéseket vetnek fel mind a sportszakmában, mind a sportszakmán kívül tevékenykedőkben. Lényeges kérdés, hogy ezek az akadémiák honnan szerzik a finanszírozási, támogatási hátterüket, van-e egységes tipológia vagy pedig mindenki különbözőképpen oldja meg a kérdést. Rábai (2016) kutatási eredményeiből kiderült, hogy nincs egységes rendszer ilyen téren, tudunk különbséget tenni az akadémiák között finanszírozási, múködési, infrastrukturális és edzői apparátus hátterében egyaránt. Kíváncsiak voltunk arra, hogy ezen felmerülő kérdések, hiányosságok mentén milyen jellegzetességgel bírnak a labdarúgó akadémiák elérhető honlapjai, vajon az oldalak mennyiben frissek, informatívak, mennyire nyújtanak releváns információkat az adott labdarúgó akadémiáról. A mai, technológiai szempontból egyre rohamosabban fejlődő világban elengedhetetlen, hogy az interneten is fellelhetőek legyenek az adatok egy-egy intézményról, jelen esetben a labdarúgó akadémiákról. Mivel a technika rohamosan fejlődik, így az emberek többsége inkább az internet segítségével igyekszik különböző információkat beszerezni adott kérdések megválaszolásához. Ezért is gondoljuk azt, hogy a labdarúgó akadémiáknak szükséges rendelkezniük informatív, minél több adatot és elérhetőséget tartalmazó weboldallal, hiszen ezáltal a szülők is könnyebben tudnak válogatni az akadémiák között, a honlapok dús információbázisa az ő választásukat segíti elő. Tudniillik ilyen téren az akadémiák között is versenyhelyzet van, nyilván az is a célja az intézményeknek, hogy minél több fiatalt foglalkoztassanak, minél több szülő bizalmát nyerjék el. Ehhez azonban szükséges egy olyan arculat, amelyet egy saját honlap is képviselhet.

A hatékony elemzés érdekében sajátos szempontrendszert hoztunk létre, amely alapján megvizsgáltuk a labdarúgó akadémiák honlapjait. Rábai (2016) kutatásában három labdarúgó akadémiai csoportot különített el: az él- és profisport-orientált, a 
formálódó profilú és az egyházi fenntartású akadémiákat (Rábai 2016). Kérdésünk az is, hogy ezen felosztásban milyen különbségek vannak az akadémiák között, beigazolódik-e az a felvetés, hogy a már régebb óta múködő, jobb infrastrukturális és nagyobb edzői apparátussal rendelkező akadémiák informatívabb, sokkalta frissebb weboldallal rendelkeznek, mint a még formálódó profilú, fiatalabb és alacsonyabb infrastrukturális adottságokkal rendelkező akadémiák. Az első fő elemzési szempontunk, hogy az adott labdarúgó akadémia rendelkezik-e névadóval, amennyiben igen, akkor van-e rá utalás. Második elemzési szempontunk az oktatási intézmény megjelenésének kérdése volt a honlapokon, van-e utalás rájuk, milyen részletességében fejtik ki az akadémiák az oktatási intézményeiket, amelyben a náluk fejlődő fiatalok az oktatási kötelezettségeiket teljesítik. Harmadik elemzési szempontként jelent meg az akadémiák célkitüzéseinek, feladatainak a megfogalmazása. Kérdés, hogy az akadémiák között milyen különbségek vannak ezen aspektusokból, megemlítik-e a fő célokat, feladatokat, amelyeket az akadémiájuk képvisel. Negyedik elemzési szempontunk, hogy az akadémiák honlapjain mennyire frissek a játékoskeretek, illetve az adott korosztályok eredményei. Ebből a kérdésből is sok következtetést le lehet vonni: ha naprakész eredményeket olvashatunk az akadémiák honlapjain, illetve a különböző korcsoportok játékoskeretei is frissek, akkor valószínúleg a honlap folyamatos kezelés alatt áll, így hetente kerülnek fel az aktuális eredmények. Utolsó elemzési szempontunk a fóbb dokumentumok megjelentetése a honlapokon, fókuszálva az alapító okiratra, illetve a különböző fejlesztési dokumentumokra. Úgy véljük, hogy az intézményeknek szükséges lenne elérhetôvé tenniük a dokumentumaikat, részint azért, mert ezzel tudnák igazolni az esetleges infrastrukturális gyarapodást, részint pedig azért, mert így az akadémiákkal kapcsolatosan kialakult sztereotípiákat cáfolhatnák meg. Végül ötös skálán értékeltük az akadémiák összbenyomását, figyelembe véve az említett elemzési egységeket.

Az alábbi táblázat az elemzési eredményeket tartalmazza:

1. táblázat. A labdarúgó akadémiák honlapjainak elemzése a különböző szempontok mentén

\begin{tabular}{|c|c|c|c|c|c|c|}
\hline $\begin{array}{l}\text { Labdarúgó } \\
\text { akadémia }\end{array}$ & $\begin{array}{l}\text { Honlap } \\
\text { ellátottsága } \\
(1-5)\end{array}$ & $\begin{array}{l}\text { Az aka- } \\
\text { démia } \\
\text { névadója, } \\
\text { története }\end{array}$ & $\begin{array}{l}\text { Az oktatás, } \\
\text { az oktatási } \\
\text { intézmény } \\
\text { megjelenése } \\
\text { a honlapon }\end{array}$ & $\begin{array}{l}\text { Az akadé- } \\
\text { mia célki- } \\
\text { tűzéseinek, } \\
\text { feladatai- } \\
\text { nak megfo- } \\
\text { galmazása }\end{array}$ & $\begin{array}{l}\text { Az akadé- } \\
\text { mista kor- } \\
\text { csoportok } \\
\text { játékoske- } \\
\text { retei, friss } \\
\text { eredményei } \\
\text { (korcsopor- } \\
\text { tonként) }\end{array}$ & $\begin{array}{l}\text { Főbb doku- } \\
\text { mentumok } \\
\text { (alapító } \\
\text { okirat, } \\
\text { fejlesztési } \\
\text { dokumen- } \\
\text { tumok) }\end{array}$ \\
\hline $\begin{array}{l}\text { 1. Puskás } \\
\text { Ferenc } \\
\text { Labdarúgó } \\
\text { Akadémia, } \\
\text { Felcsút }\end{array}$ & 5 & $\begin{array}{l}\text { Teljes, } \\
\text { bőséges }\end{array}$ & Megjelenik & Megjelenik & Teljes, friss & $\begin{array}{l}\text { Alapító } \\
\text { okirat } \\
\text { hiányzik }\end{array}$ \\
\hline $\begin{array}{l}\text { 2. Debre- } \\
\text { ceni Lab- } \\
\text { darúgó } \\
\text { Akadémia, } \\
\text { Debrecen }\end{array}$ & 3 & - & $\begin{array}{l}\text { Nem } \\
\text { jelenik meg }\end{array}$ & Megjelenik & $\begin{array}{l}\text { A játékoske- } \\
\text { retek meg- } \\
\text { jelennek, az } \\
\text { eredmények } \\
\text { hiányosak }\end{array}$ & $\begin{array}{l}\text { Alapító } \\
\text { okirat } \\
\text { hiányzik }\end{array}$ \\
\hline
\end{tabular}




\begin{tabular}{|c|c|c|c|c|c|c|}
\hline $\begin{array}{l}\text { Labdarúgó } \\
\text { akadémia }\end{array}$ & $\begin{array}{l}\text { Honlap } \\
\text { ellátottsága } \\
(1-5)\end{array}$ & $\begin{array}{l}\text { Azaka- } \\
\text { démia } \\
\text { névadója, } \\
\text { története }\end{array}$ & $\begin{array}{l}\text { Az oktatás, } \\
\text { az oktatási } \\
\text { intézmény } \\
\text { megjelenése } \\
\text { a honlapon }\end{array}$ & $\begin{array}{l}\text { Az akadé- } \\
\text { mia célki- } \\
\text { tûzéseinek, } \\
\text { feladatai- } \\
\text { nak megfo- } \\
\text { galmazása }\end{array}$ & $\begin{array}{l}\text { Az akadé- } \\
\text { mista kor- } \\
\text { csoportok } \\
\text { játékoske- } \\
\text { retei, friss } \\
\text { eredményei } \\
\text { (korcsopor- } \\
\text { tonként) }\end{array}$ & $\begin{array}{l}\text { Főbb doku- } \\
\text { mentumok } \\
\text { (alapító } \\
\text { okirat, } \\
\text { fejlesztési } \\
\text { dokumen- } \\
\text { tumok) }\end{array}$ \\
\hline $\begin{array}{l}\text { 3. Sándor } \\
\text { Károly } \\
\text { Akadémia, } \\
\text { Agárd }\end{array}$ & 5 & $\begin{array}{l}\text { Teljes, } \\
\text { bőséges }\end{array}$ & Megjelenik & Megjelenik & Teljes, friss & $\begin{array}{l}\text { Alapító } \\
\text { okirat } \\
\text { hiányzik }\end{array}$ \\
\hline $\begin{array}{l}\text { 4. Magyar } \\
\text { Futball } \\
\text { Akadémia, } \\
\text { Budapest }\end{array}$ & 4 & - & Megjelenik & Megjelenik & Teljes, friss & $\begin{array}{l}\text { Nincsenek } \\
\text { elérhető } \\
\text { dokumen- } \\
\text { tumok }\end{array}$ \\
\hline $\begin{array}{l}\text { 5. Illés } \\
\text { Akadémia, } \\
\text { Szombat- } \\
\text { hely }\end{array}$ & 5 & $\begin{array}{l}\text { Teljes, } \\
\text { bőséges }\end{array}$ & Megjelenik & Megjelenik & $\begin{array}{l}\text { Játékoske- } \\
\text { retek nin- } \\
\text { csenek, az } \\
\text { eredmények } \\
\text { frissek }\end{array}$ & $\begin{array}{l}\text { Alapító } \\
\text { okirat } \\
\text { hiányzik }\end{array}$ \\
\hline $\begin{array}{l}\text { 6. Fehér } \\
\text { Miklós } \\
\text { Labdarúgó } \\
\text { Akadémia, } \\
\text { Győr }\end{array}$ & 5 & $\begin{array}{l}\text { Teljes, } \\
\text { bőséges }\end{array}$ & $\begin{array}{l}\text { Teljes, } \\
\text { bőséges }\end{array}$ & Megjelenik & $\begin{array}{l}\text { Játékoske- } \\
\text { retek, friss } \\
\text { eredmények } \\
\text { nincsenek, } \\
\text { csak az } \\
\text { akadémia } \\
\text { által kiemelt } \\
\text { tehetségek }\end{array}$ & $\begin{array}{l}\text { Alapító } \\
\text { okirat } \\
\text { megjelenik }\end{array}$ \\
\hline $\begin{array}{l}\text { 7. Újpest } \\
\text { FC Elit } \\
\text { Akadémia, } \\
\text { Újpest }\end{array}$ & 3 & - & $\begin{array}{l}\text { Nem } \\
\text { jelenik meg }\end{array}$ & $\begin{array}{l}\text { Nem } \\
\text { jelenik meg }\end{array}$ & $\begin{array}{l}\text { Játékos } \\
\text { keretek } \\
\text { nincsenek, } \\
\text { az eredmé- } \\
\text { nyek frissek }\end{array}$ & $\begin{array}{l}\text { Alapító } \\
\text { okirat } \\
\text { hiányzik, } \\
\text { kevés elér- } \\
\text { hetôn doku- } \\
\text { mentum }\end{array}$ \\
\hline $\begin{array}{l}\text { 8. Bozsik } \\
\text { József } \\
\text { Labdarúgó } \\
\text { Akadémia, } \\
\text { Nyíregy- } \\
\text { háza }\end{array}$ & - & - & - & - & - & - \\
\hline $\begin{array}{l}\text { 9. Vasas } \\
\text { Kubala } \\
\text { Akadémia, } \\
\text { Budapest }\end{array}$ & 5 & $\begin{array}{l}\text { Teljes, } \\
\text { bőséges }\end{array}$ & $\begin{array}{l}\text { Teljes, } \\
\text { bőséges }\end{array}$ & Megjelenik & Teljes, friss & $\begin{array}{l}\text { Alapító } \\
\text { okirat } \\
\text { hiányzik, } \\
\text { hiányosak } \\
\text { a dokumen- } \\
\text { tumok }\end{array}$ \\
\hline $\begin{array}{l}\text { 10. Kapos- } \\
\text { vári Rákóczi } \\
\text { Bene Ferenc } \\
\text { Labdarúgó } \\
\text { Akadémia, } \\
\text { Kaposvár }\end{array}$ & 3 & $\begin{array}{l}\text { Nem } \\
\text { jelenik meg }\end{array}$ & Megjelenik & $\begin{array}{l}\text { Nem } \\
\text { jelenik meg }\end{array}$ & Teljes, friss & $\begin{array}{l}\text { Alapító } \\
\text { okirat } \\
\text { hiányzik, } \\
\text { hiányosak } \\
\text { a dokumen- } \\
\text { tumok }\end{array}$ \\
\hline
\end{tabular}




\begin{tabular}{|c|c|c|c|c|c|c|}
\hline $\begin{array}{l}\text { Labdarúgó } \\
\text { akadémia }\end{array}$ & $\begin{array}{l}\text { Honlap } \\
\text { ellátottsága } \\
(1-5)\end{array}$ & $\begin{array}{l}\text { Az aka- } \\
\text { démia } \\
\text { névadója, } \\
\text { története }\end{array}$ & $\begin{array}{l}\text { Az oktatás, } \\
\text { az oktatási } \\
\text { intézmény } \\
\text { megjelenése } \\
\text { a honlapon }\end{array}$ & $\begin{array}{l}\text { Az akadé- } \\
\text { mia célki- } \\
\text { tűzéseinek, } \\
\text { feladatai- } \\
\text { nak megfo- } \\
\text { galmazása }\end{array}$ & $\begin{array}{l}\text { Az akadé- } \\
\text { mista kor- } \\
\text { csoportok } \\
\text { játékoske- } \\
\text { retei, friss } \\
\text { eredményei } \\
\text { (korcsopor- } \\
\text { tonként) }\end{array}$ & $\begin{array}{l}\text { Főbb doku- } \\
\text { mentumok } \\
\text { (alapító } \\
\text { okirat, } \\
\text { fejlesztési } \\
\text { dokumen- } \\
\text { tumok) }\end{array}$ \\
\hline $\begin{array}{l}\text { 11. Békés- } \\
\text { csaba } \\
\text { Labdarúgó } \\
\text { Akadémia, } \\
\text { Békéscsaba }\end{array}$ & 2 & - & $\begin{array}{l}\text { Nem } \\
\text { jelenik meg }\end{array}$ & $\begin{array}{l}\text { Nem } \\
\text { jelenik meg }\end{array}$ & Teljes, friss & $\begin{array}{l}\text { Nincsenek } \\
\text { elérhetố } \\
\text { dokumen- } \\
\text { tumok }\end{array}$ \\
\hline $\begin{array}{l}\text { 12. Diós- } \\
\text { győri } \\
\text { Futball } \\
\text { Akadémia, } \\
\text { Miskolc }\end{array}$ & - & - & - & - & & - \\
\hline $\begin{array}{l}\text { 13. Szent } \\
\text { István } \\
\text { Futball } \\
\text { Akadémia, } \\
\text { Budapest }\end{array}$ & 1 & - & $\begin{array}{l}\text { Nem } \\
\text { jelenik meg }\end{array}$ & $\begin{array}{l}\text { Nem } \\
\text { jelenik meg }\end{array}$ & $\begin{array}{l}\text { Elavultak, } \\
\text { nem frissek } \\
\text { (2009-es } \\
\text { hírek) }\end{array}$ & $\begin{array}{l}\text { Nincsenek } \\
\text { elérhető } \\
\text { dokumen- } \\
\text { tumok }\end{array}$ \\
\hline $\begin{array}{l}\text { 14. Buda- } \\
\text { keszi } \\
\text { Labdarúgó } \\
\text { Akadémia, } \\
\text { Budakeszi }\end{array}$ & 2 & - & $\begin{array}{l}\text { Nem jelenik } \\
\text { meg }\end{array}$ & Megjelenik & $\begin{array}{l}\text { Elavultak, } \\
\text { nem frissek }\end{array}$ & $\begin{array}{l}\text { Alapító } \\
\text { okirat } \\
\text { hiányzik }\end{array}$ \\
\hline $\begin{array}{l}\text { 15. Kecske- } \\
\text { méti } \\
\text { Labdarúgó } \\
\text { Akadémia, } \\
\text { Kecskemét }\end{array}$ & - & - & - & - & - & - \\
\hline $\begin{array}{l}\text { 16. Pécsi } \\
\text { Futball } \\
\text { Akadémia, } \\
\text { Pécs }\end{array}$ & - & 3 & - & - & - & - \\
\hline $\begin{array}{l}\text { 17. Szőcs } \\
\text { János } \\
\text { Labdarúgó } \\
\text { Akadémia, } \\
\text { Zalaeger- } \\
\text { szeg }\end{array}$ & 3 & $\begin{array}{l}\text { Teljes, } \\
\text { bőséges }\end{array}$ & $\begin{array}{l}\text { Nem } \\
\text { jelenik meg }\end{array}$ & Megjelenik & $\begin{array}{l}\text { Megjelen- } \\
\text { nek, az } \\
\text { eredmények } \\
\text { nem frissek } \\
\text { (2015-ösök) }\end{array}$ & $\begin{array}{l}\text { Alapító } \\
\text { okirat } \\
\text { hiányzik }\end{array}$ \\
\hline $\begin{array}{l}\text { 18. Grosics } \\
\text { Gyula } \\
\text { Katolikus } \\
\text { Labdarúgó } \\
\text { Akadémia, } \\
\text { Gyula }\end{array}$ & 5 & $\begin{array}{l}\text { Teljes, } \\
\text { bőséges }\end{array}$ & Megjelenik & Megjelenik & Teljes, friss & $\begin{array}{l}\text { Alapító } \\
\text { okirat } \\
\text { hiányzik }\end{array}$ \\
\hline
\end{tabular}

Forrás: saját szerkesztés 
Összesen 18 labdarúgó akadémia honlapja került átfogó elemzés alá, a már elóbb említett kérdések mentén. Négy akadémia esetében nem lehetett elvégezni az elemzést, ugyanis az adott akadémiák (Bozsik József Labdarúgó Akadémia - Nyíregyháza, Diósgyőri Futball Akadémia - Miskolc, Kecskeméti Labdarúgó Akadémia - Kecskemét, illetve Pécsi Futball Akadémia - Pécs) esetében nem találtunk saját honlapot sem. Ami érdekesség, hogy mind a négy előbb említett akadémia a formálódó profilú kategória tagja, ami erősíti azt, hogy a saját honlap is kialakuló fázisban lehet, magával az akadémiával együtt.

Egy akadémia kivételével a honlapokon nem jelenik meg az alapító okirat. Álláspontunk szerint ez nagy probléma, ugyanis az alapító okiratban olyan információk jelennek meg, amelyekről az adott akadémia kapcsán több esszenciális kérdésre is választ kaphatunk. Ilyen információk például az alapítás éve, a fenntartó típusa, az oktatási intézményekkel való kapcsolata. Egyedül azonban a győri székhellyel rendelkező Fehér Miklós Labdarúgó Akadémia tette elérhetővé ezt a dokumentumot, mindamellett ez jelzi a többi akadémia hiányosságát. Ha kategóriákra bontva szeretnénk releváns konzekvenciákat levonni, akkor elmondhatjuk, hogy a legjobb értékelést az él- és profisport-orientált akadémiák kapták. Ezek között a Debreceni Labdarúgó Akadémia kapta a legalacsonyabb (3) értékelést, ugyanis itt az oktatási intézmény sem jelenik meg, illetve az akadémista korcsoportok eredményei sem frissek. Erról a kategóriáról elmondható, hogy a legimpozánsabb honlapokkal rendelkeznek, az adataik, eredményeik többnyire frissek, ügyelnek az igényes külcsínre és az informatív megjelenésre. A legjobb összeredménnyel ezek közül a Fehér Miklós Labdarúgó Akadémia rendelkezik, hiszen itt ugyan nincsenek megjelenítve külön a játékoskeretek a korcsoportokban, de az alapító okirat, az oktatási intézmények és a fốbb dokumentumok egyaránt elérhetőek. A kategória további akadémiái (Illés Akadémia - Szombathely, Magyar Futball Akadémia - Budapest, Sándor Károly Akadémia - Agárd, illetve Puskás Ferenc Labdarúgó Akadémia - Felcsút) között lényeges különbségek nem voltak, a legfốbb hiányosság azonban közös volt, méghozzá az alapító okirat közzétételének hiánya. Összességében ez a kategória képviseli a legjobb eredményeket az elemzés alapján.

A formálódó profilú akadémiák esetében már mutatkoztak jelentős különbségek. A kategória már említett négy akadémiája saját honlappal sem rendelkezik, akiknek pedig van saját honlapjuk, azok között is mutatkoztak differenciák. Összességében a Vasas Kubala László Akadémia kapta a legjobb összpontszámot (5), ugyanis itt minden elemzési szempontnak eleget tett az akadémia, egyedül az alapító okirat, illetve az egyéb dokumentumok hiányoztak vagy voltak hiányosak. A kategóriát jellemezte, hogy általában nem voltak frissek az eredmények (valahol a legfrissebb hírek 2009-esek, azaz hét évvel ezelöttiek voltak), illetve nagyon kevés dokumentumot tettek közé ezek az akadémiák. Érezhető volt az elemzés során, hogy rendkívül hiányosak a honlapok, értékes tartalommal nincsenek megtöltve. Az oktatási intézmények megjelenése is elég vegyes képet mutat, hol van rájuk utalás, hol pedig nincs. Az akadémiák elemzése során a „formálódó profilú” elnevezést alátámasztották az eredmények, több szempontból is el vannak maradva ezek az akadémiák az él- és profisport-orientált akadémiáktól. 
Az egyedüli kategóriát képviselő, gyulai székhellyel rendelkező Grosics Gyula Katolikus Labdarúgó Akadémia szintén a legmagasabb (5) minősítést érte el az elemzés során. Az alapító okiraton kívül minden más adat, tartalom nagyon impozáns, megjelenik a névadóra való utalás és bemutatás, a korcsoportok eredményei frissek, naprakészek, az oktatási intézmények és a célkitűzések is egyaránt megtalálhatóak. Az alapító okiraton kívül vannak fellelhető dokumentumok, amelyek leginkább az akadémia fejlesztésével kapcsolatosak.

Kíváncsiak voltunk arra is, hogy a toborzás terén milyen különbségek vannak az akadémiák között. ${ }^{15}$ Véleményünk szerint fontos, hogy az akadémiák kellő információkkal lássák el a szülőket azzal kapcsolatban, hogy mikor, hol vannak a toborzók, hogyan lehet jelentkezni ezekre az alkalmakra, ezért tüntettük fel külön táblázatban az eredményeket. Az akadémiák szempontjából is fontos, hogy ez az információ frissen kerüljön ki a honlapra, ezáltal segítve a tájékozódást a jelentkezők számára. A toborzás szempontjából vizsgálódva jelentek meg különbségek az akadémiák között, amelyet az alábbi táblázat szemléltet:

2. táblázat. A toborzás megjelentetése a honlapokon

\begin{tabular}{|c|c|}
\hline Labdarúgó Akadémia & Toborzó (megjelenése, formája) \\
\hline Puskás Ferenc Labdarúgó Akadémia, Felcsút & Van, partneregyesület ajánlása szükséges \\
\hline Debreceni Labdarúgó Akadémia, Debrecen & Van, jelentkezési lap elérhetô a honlapon \\
\hline Sándor Károly Akadémia, Agárd & $\begin{array}{l}\text { Van, játékosmegfigyelők ajánlása szükséges a fel- } \\
\text { vételhez }\end{array}$ \\
\hline Magyar Futball Akadémia, Budapest & Nincs \\
\hline Illés Akadémia, Szombathely & Van, jelentkezési lap elérhető a honlapon \\
\hline Fehér Miklós Labdarúgó Akadémia, Győr & Van, jelentkezési lap elérhető a honlapon \\
\hline Újpest FC Elit Akadémia, Budapest & Nincs \\
\hline Bozsik József Labdarúgó Akadémia, Nyíregyháza & - \\
\hline Vasas Kubala Akadémia, Budapest & Van, jelentkezési lap elérhető a honlapon \\
\hline $\begin{array}{l}\text { Kaposvári Rákóczi Bene Ferenc Labdarúgó Aka- } \\
\text { démia, Kaposvár }\end{array}$ & Van, e-mailben kell jelentkezni \\
\hline Békéscsaba Labdarúgó Akadémia, Békéscsaba & Nincs \\
\hline Diósgyőri Futball Akadémia, Miskolc & - \\
\hline Szent István Futball Akadémia, Budapest & Nincs \\
\hline Budakeszi Labdarúgó Akadémia, Budakeszi & Nincs \\
\hline Kecskeméti Labdarúgó Akadémia, Kecskemét & - \\
\hline Pécsi Futball Akadémia, Pécs & - \\
\hline Szőcs János Labdarúgó Akadémia, Zalaegerszeg & Nincs \\
\hline $\begin{array}{l}\text { Grosics Gyula Katolikus Labdarúgó Akadémia, } \\
\text { Gyula }\end{array}$ & Van, jelentkezési lap elérhető a honlapon \\
\hline
\end{tabular}

Forrás: saját szerkesztés

15 Ezen eredményeket külön kezeltük, ezért nem láthatók szempontként az előző táblázatban. 
A táblázat jól szemlélteti, hogy összességében az él- és profisport-orientált akadémiák, illetve az egyházi fenntartású akadémia is nagyobb hangsúlyt fektet a toborzókra, mint a fejlődő profilúak. Két akadémia esetében (Sándor Károly Akadémia - Agárd és Puskás Ferenc Labdarúgó Akadémia - Felcsút) az egyik partner együttes vagy pedig a játékosfigyelők ajánlása szükséges a felvételhez, így a két akadémia esetében további szelekciós faktor is érvényben van. A formálódó profilú akadémiák ilyen téren is jelentősen el vannak maradva az előzőleg említett két akadémiai kategóriához képest.

Elmondható, hogy jelentős különbségeket tapasztaltunk a labdarúgó akadémiák honlapjainak elemzése során mind a kategóriák, mind az akadémiák szintjén vizsgálódva. Ami legfőbb problémaként jelentkezett, hogy nem volt elérhetố egy akadémia kivételével az alapító okirat, amelyet mindenképpen szükséges lenne az intézmények esetében megjeleníteni. A legjobb értékeléseket az él- és profisport-orientált akadémiák kapták, ugyanis itt találkozhattunk a leginformatívabb, leginkább naprakész, legimpozánsabb honlapokkal. A formálódó profilú akadémiák esetében négy akadémia saját honlappal sem rendelkezett, csupán a felnőttcsapat weboldalán volt egy menüpont nyilvántartva, de valahol még ez sem. Itt vegyes képet mutattak a honlapok, leginkább azonban a hiányosság volt a legfő́bb eredmény, amely ezt a kategóriát jellemezte. A Grosics Gyula Katolikus Labdarúgó Akadémia esetében szintén a legjobb értékelés született, ugyanis a sajátos arculat mellé a friss eredmények és az oktatási intézmények részletes bemutatása társult. Itt is hiányzott az alapító okirat, viszont a különböző fejlesztéseket igazoló dokumentumok elérhetőek a honlapon. Az akadémiai kategóriák mellett az akadémiák között is voltak különbségek. Az elemzési szempontokat figyelembe véve összességében a leghatásosabb honlapokkal a Fehér Miklós Labdarúgó Akadémia, a Puskás Ferenc Labdarúgó Akadémia, a Sándor Károly Labdarúgó Akadémia, illetve a Grosics Gyula Labdarúgó Akadémia rendelkeznek. A középkategóriát képviseli az Illés Akadémia, a Magyar Futball Akadémia, a Vasas Kubala Akadémia, valamint a Debreceni Labdarúgó Akadémia. A legalsó kategóriát hat akadémia alkotja, az Újpest FC Elit Akadémia, a Békéscsaba Labdarúgó Akadémia, a Budakeszi Labdarúgó Akadémia, a Szent István Labdarúgó Akadémia, a Kaposvári Rákóczi Bene Ferenc Labdarúgó Akadémia, illetve a Szőcs János Labdarúgó Akadémia. A legnagyobb probléma azoknál az akadémiáknál van, ahol saját honlap sincs nyilvántartva. Ezzel nagy hátrányba kerülhetnek a többiekhez képest, hiszen az a szülő, aki az interneten keresztül szeretne tájékozódni egy adott akadémia elérhetőségeirôl, ezekről az akadémiákról nem tud releváns információkat kapni. Szükséges, hogy ôk is foglalkozzanak a problémával és mihamarabb kialakítsanak egy saját weboldalt, amely a leginkább szemlélteti az akadémiájukat.

\section{A kutatási probléma az MLSZ aspektusában}

Az akadémiák önmeghatározása szerint az MLSZ pontosan meghatározza az intézménytípus sajátosságait, azt, hogy milyen feltételeknek kell megfelelniük. A Magyar Labdarúgó Szövetség 2012-ben elfogadott minősítési elvei rendezik az akkreditációs 
eljárás menetét, ${ }^{16}$ illetve az akkreditációval foglalkozó szövetségi testület összetételét, múködési rendjét. ${ }^{17} \mathrm{E}$ szerint az MLSZ akkreditációs bizottsága a pályázó által összeállított dokumentáció és helyszíni vizsgálódás alapján hozza meg döntését, melynek alapján hároméves periódusra engedélyezi az akadémia múködését. Az akkreditációs elvek nem határozzák meg az akadémiák lehetséges legnagyobb számát, de kijelentik, hogy demográfiai és gazdaságossági szempontoknak kell meghatározniuk az akadémiák fenntartását.

A minősítési dokumentáció 2012-ben a következő elveket határozta meg:

1. A létesítendő akadémiának első osztályú futballklubbal kell szervezeti, jogi vagy tulajdonosi kapcsolatban állnia, mely kapcsolat lehetővé teszi, hogy az akadémisták közvetlenül, átigazolás nélkül kerüljenek első osztályú klub játékosállományába.

2. Az akadémiának saját megyéje mellett egy szomszédos megyére is ki kell terjesztenie tevékenységét. (Ha már múködik ott akadémia, külön eljárás alá kell vonni a kérelmet.) Ez a területi elv ismét csak korlátozhatná az akadémiák számát. A minősítés kritériumrendszere négy értékelési dimenziót jelöl meg, melyeket alapfeltételnek nevez. Ezek a következők:

a) Tanulási feltételek

b) Lakhatási, ellátási feltételek

c) Szakmai feltételek

d) Intézményi feltételek

Az egyes alapfeltételeket a következő kritériumokban kívánja megragadni az MLSZ:

a) Tanulási feltételek:

- Biztosítja-e az akadémia a törvényi előírásoknak megfelelően a hallgatók számára a tanulási feltételeket? (Nem kötelező a saját szervezés, de szempont a minőség: a külső intézménynek kiváló minőségűnek kell lennie. Nem kötelező az akadémia területén folynia az oktatásnak, de a könnyű elérhetőség alapvető feltétel.)

- Az oktatási feltételeknek garantálnia kell az általános iskola elvégzését minden hallgató számára, sőt korrepetálást is szükség esetén, illetve igény szerint a középiskolát is (optimális esetben választható gimnáziumi, szakközépiskolai, szakmunkásképző iskolai lehetőségekkel).

- Az oktatásnak néhány speciális területre külön hangsúllyal ki kell terjednie, így az idegennyelv-oktatásra, az állampolgári ismeretekre, az egészséges életmódra, a jövőbeni munkavállalásra való felkészülésre.

- Az oktatás infrastrukturális feltételeinek minősége (pedagógusok száma, végzettsége, fóállású iskolai koordinátor, szociális gondozó, kollégiumi nevelőtanár stb.).

16 Az akkreditációs elvek bizonytalanságát mutatja, hogy már 2013-ban megkezdődik az auditálási eljárás, melynek célja az akkreditáció felülvizsgálata. Sőt ugyanezzel a céllal 2016-ra tervezik az akadémiák teljes átvilágítását.

17 Tájékoztató a labdarúgó akadémiai licenceminősítési eljárásról. Forrás: www.mlsz.hu/wpcontent/uploads/2012/10/akademiai-licenc-minositesi-eljaras-tajekoztato.doc. 
b) Lakhatási, ellátási feltételek:

- a hallgatók elszállásolására szolgáló kizárólagos használatú épület jellemzői (maximum háromfős szobák, közösségi és szabadidős helyiségek, tanulószoba, internet, könyvtár stb.)

- szakszerū és minőségi étkeztetés az akadémia éttermében

- egészségügyi ellátás

- harmonikus egység a gyakorlás, tanulás és pihenés között

c) Szakmai feltételek:

- képzési és nevelési tervek megléte

- képzett munkatársak, igazgató, edzők szakmai licence, tapasztalata, nyelvtudása

- orvos, masszőr, rehabilitációs szakemberek szakértelme, végzettsége

- egészségügyi program

- megfelelő infrastruktúra: pályaellátottság, konditerem, egészségügyi helyiségek

- eredményesség: felnőtt korosztályba kibocsátott játékosok száma, foglalkoztatottsága, a korosztályos válogatottakba adott játékosok száma, foglalkoztatottsága

d) Intézményi feltételek:

- szervezeti fejlettség, átláthatóság, önállóság (üzleti terv, főkönyvelő, beszámoló, hivatalos nyilvántartás az akadémistákról)

- regionális szervező szerep (két szomszédos megyére kiterjedő szakmai kapcsolatrendszer)

- régión túli kapcsolatok (régión túl nyúló érdemi szakmai kapcsolat, határon túli stb.)

- nemzetközi szakmai tevékenység (nemzetközi szakmai tevékenység, részvétel külföldi túrán, tornán, edzőmérkőzésen, szakemberek csereprogramja külfölddel)

- akadémia tekintélye (ismertsége, elismertsége, megyében, országban, külföldön, saját kiadvány, hírlevél, újság, album, honlap stb.)

- együttműködés az MLSZ-szel

A minősítő bizottság a fentiek figyelembevételével dönt az akadémia alkalmasságáról, illetve alkalmasság esetén minősítéséről. A fenti kritériumrendszer egy sajátosságát kívánjuk kiemelni, saját szempontunk szerint ugyanis nagyon fontosnak tartjuk, hogy mennyire hangsúlyos része a kritériumrendszernek a tanulási feltételek meglétének vizsgálata. Szimbolikus jelentőségű, hogy ez a feltételcsoport kapja az első helyet, ezzel mintegy kiemelve az értékét ennek a szervezési dimenziónak. Ez az első eset, és tapasztalataink szerint gyakorlatilag az egyetlen, amikor az akadémiákkal kapcsolatban a sportszakmai értékek nem szorítják teljesen háttérbe, nem teszik másodlagossá az iskoláztatással, tanulással járó elfoglaltságokat az akadémisták életében. Fontosnak tartjuk kiemelni, hogy ez a szemlélet ritka, tartósan a rendszerben nem is érvényesül a szándéka, magasabb szintű jogszabályban nyomát sem találjuk, de mindenképpen kiemelendő megközelítés. Mindenképpen érdemes kiemelnünk, hogy a kritériumok 
a hallgatók hozzáférése mellett iskolai előmenetelüket is fontosnak tartja, számukra a továbbtanulás támogatását, választási opciók meglétét is kívánatosnak tartja, sőt elvárja. Fontos megemlítenünk, hogy a diákokkal kapcsolatban álló nevelők pedagógiai végzettsége itt előfordul fontos szempontként, de talán az itt előírtnál nagyobb hangsúllyal is szerepelhetne, hiszen tudomásunk szerint ma is sok akadémia müködik képzési-nevelési koordinációval megbízott fóállású pedagógiai képzettségű munkatárs nélkül, ${ }^{18}$ holott ezt elengedhetetlenül fontosnak tartjuk, de azt is, hogy egy ilyen munkatárs munkáját például szociálpedagógiai végzettségű asszisztensek, szociális munkások segítsék, különösen a fokozott hátrányokkal küzdő régiókban. Fontos lenne ez azért is, mert a kritériumként megfogalmazott támogatást (korrepetálás) igazából csak szakképzett pedagógusok tudnák szavatolni, de nagyobb figyelmet érdemelne az internátusi elhelyezés során a diákokkal foglalkozó nevelők és egyéb személyzet pedagógiai felkészültségének előírása is, és talán nem lenne elképzelhetetlen a szakmai személyzet, az edzők és vezetők pedagógiai felkészültségének mérlegelése sem.

Vannak tehát kedvező elemek a szabályozásban, azonban az MLSZ meghatározása véleményünk szerint korántsem elég - az akadémiák múködésének komplexitása miatt szükséges lenne a magasabb szintű jogszabályokat pontosítani, bennük definiálni a labdarúgó akadémiákra vonatkozó szabályozást. Természetes és indokolt volna a sporttörvény szabályozása ezen a téren, hiszen az utánpótlás-nevelés speciális intézményeként az akadémiák pontosan definiálható feladatot végeznek, a források jelentős szeletét lekötve. De véleményünk szerint a köznevelési törvény szövegében is indokolt lehetne az akadémiákkal foglalkozni, hiszen az akadémiák több értelemben is szereplői a közoktatási és köznevelési rendszernek. Egyes akadémiák intézményfenntartóként is szerepet vállalnak, ${ }^{19}$ sajátos profilú, sajátos érték- és célrendszerrel rendelkező nevelő és életkörnyezetet alakítanak ki a tankötelezett korú vagy abból éppen csak kinövő fiatalok számára, amely gyakran összeütközésbe kerül a közoktatás általános elveivel. Hogy csak egy példát említsünk, nem kis feszültséget szül például az akadémisták (akadémista osztályok) eltérő életrendjének, igényeinek kezelése egy olyan iskolában, ahol nem akadémistákkal együtt tanulnak a labdarúgók. ${ }^{20}$ De indokolná az is, hogy míg a köznevelési törvény pontosan definiálja a mưvészeti tehetséggondozás tevékenység- és intézményrendszerét, addig a teljesen logikus analógiát el nem ismerve nem szól a sporttehetség-gondozás létező intézménystruktúrájáról.

18 A korábban említett Double Pass audit releváns megállapításai szerint probléma, hogy nem minden akadémia alkalmaz szociális és oktatási vezetőt, sőt nem minden akadémián áll rendelkezésre olyan alkalmazott, aki kizárólag a szociális és oktatási ügyekért felel. Mindössze az akadémiák fele múködik együtt pszichológussal, pszichológiai múhelymunkák és profilvizsgálat kevés akadémián elérhető. Bár a legtöbb akadémia rendelkezik oktatási programmal, prevenciós program kidolgozása és független tanácsadó foglalkoztatása nem elterjedt (www.mlsz.hu/wpcontent/uploads/2014/06/MLSZ-AUDIT_140616.pdf).

19 Például a Győri ETO FC Fehér Miklós-akadémia (pontosabban az akadémiát fenntartó ETO Jövőjéért Alapítvány) a fenntartója a Fehér Miklós Gimnázium és Kollégiumnak.

20 Gyakori, hogy az akadémisták megállapodás alapján külön osztályban tanulnak. Gyakori feszültségforrás, hogy az iskolai időbeosztást ezeknek az osztályoknak az esetében mindig felülírja az akadémiai kötelezettségek teljesítése. 


\section{A köznevelési törvény és a sporttörvény álláspontjai}

A nemzeti erőforrás miniszter 4/2011. (II. 28.) számú rendelete (az állami sportcélú támogatások felhasználásáról) II. fejezet 6 . pont 31 . § a sportakadémiai képzést a sportági szakszövetségek feladataként kezeli, és ennek kialakításában a sportkormányzat elkötelezettségét jelenti ki. A paragrafus első bekezdése szerint a magyar „sporttehetségek kiválasztásának és folyamatos nyomon követése rendszerének kiépitése érdekében" támogatja az egyes sportágak - és különösen megnevezve a labdarúgás - utánpótlás-nevelési központjainak akadémiai rendszerú fejlesztését. A rendelet 1 . bekezdésében ehhez társít néhány lényegi elemet, mely hozzásegíthet minket a sportakadémiák múködésének pontosabb értelmezéséhez. $\mathrm{E}$ pont szerint az akadémiák múködéséhez elvárásként rendeli az emelt szintú szakmai képzést, a felkészüléshez szükséges sportegészségügyi és sporttudományos hátteret, illetve intézményesített kapcsolatot, átjárhatóságot a közoktatási intézményrendszerrel. Az utolsó elvárás olyan pedagógiai dimenziót jelöl meg, amely megnyugtatóan akkor rendeződne, ha beépülne a köznevelési törvény szövegébe, garantálva, hogy az akadémiák nevelési feladatai valóban nagymértékben és tartósan összeegyeztethetőek a közoktatási intézményrendszerrel, annak elemeivel és követelményeivel. Arról nem is szólva, hogy a rendelet idézett bekezdése az időbeosztás rugalmas kialakításának céljával indokolja az akadémiai program profiljának kialakítását, aminek oka a szöveg szerint a fokozott sporttevékenységgel járó terhelés kezelése, és amely alapelv egy fontos tanulságot sugall az interpretátor számára: ez pedig a tanköteles korú akadémisták tevékenységeinek értéksorrendbe való állítása, mely sorrend (a szöveg alapján méltán levonhatjuk ezt a következtetést) a sporttevékenység megkérdőjelezhetetlen primátusán alapul, minden más, akár a tankötelezettséggel összefüggó tevékenységgel szemben is. Ez a pont ismét felveti azt a kérdést, nem kellene-e más, akár a rendeletnél magasabb jogszabályban, pontosabban a köznevelési törvényben megvédeni a tanulmányi kötelezettségeket a tanköteles korú, vagy a tankötelességet éppen csak meghaladott korú akadémisták esetében. A rendeletben lefektetett elv ugyanis kedvező helyzetbe hozza az akadémiák sportszakmai érdekeit, de hátrányosan érinthetik azokat az intézményeket, melyekben az akadémisták tanulnak, illetve összeütközések csapdáit rejtik a kettős intézményi szorításban élő akadémisták életében.

A jogszabályok mai szövegei egyértelmúen kivonnák a köznevelési törvény hatálya alól a sportakadémiák intézményi rendszerét. A köznevelési törvény (2011. évi CXC. tv.) ugyanis nem szól a sportakadémiákról. A leglogikusabban az akadémiák elméleti kontextusát meghatározó tehetséggondozás formáit vizsgálva azt láthatjuk, hogy a törvény éppen csak érintőlegesen szól a sportiskolákról is, mint a sporttehetséggondozás lehetséges intézményes keretéról a 7. § 6. pontjában, a köznevelési rendszer intézményeinek felsorolásakor. Érdemes azonban arra felhívnunk a figyelmet, hogy a köznevelési törvény a tehetséggondozás múvészettel kapcsolatos ágát ennél jóval pontosabban meghatározza, a múvészeti tehetséggondozás helyeül a múvészeti tehetséggondozás intézményrendszerét határozva meg. A törvény 16. §-a leírja az alapfokú 
művészeti iskola feladatát, mely a képességek kibontakoztatásában, a művészi tehetség fejlesztésében és igény szerint a továbbtanulás támogatásában áll. A törvény az alapfokú művészeti tehetséggondozás intézményét pontosan leírja évfolyamai száma, tevékenységi ágai szerint. Gondoskodik a törvény továbbá a tehetséggondozó munka kimeneti eredményességét mérő eszközről is, amikor meghatározza a művészeti alap- és záróvizsga letételének lehetőségét. Meghatározza továbbá a heti foglalkozások mennyiségét, az iskola infrastruktúrájának, szolgáltatásainak és eszközeinek használatához kapcsolódó elveket, sőt az ingyenesség pontos feltételeit is. Létrehoz tehát egy célracionális és komplex intézményi struktúrát a művészeti tehetségek gondozására. A köznevelési törvény passzusait sorra véve a kollégiumokra vonatkozó szabályok alkalmazása kézenfekvőnek tűnne, hiszen ezek tevékenysége valóban több közeli hasonlóságot mutat az akadémiák munkájával, sőt az akadémiák öndefinícióinak is gyakori eleme a kollégiumi forma hangsúlyozása. De a kollégium meghatározása a közoktatási törvényben nem vág egybe ezekkel az értelmezési kísérletekkel, mert a labdarúgó akadémiák fiataljai más konkrét ok miatt vesznek részt az internátusi életben, és nem a törvény 17 . $\$ 1$. bekezdés $a$ ) és $b$ ) pontjaiban említett okokból, mely szerint a kollégium:

17. \$ (1) A kollégium az a nevelési-oktatási intézmény, amely az iskolai tanulmányok folytatásáboz szükséges feltételeket biztositja, ha az

a) a lakóhelyüktöl távol tanulók számára a szabad iskolaválasztáshoz való joguk érvényesitéséhez, nemzetiségi nyelven vagy gyógypedagógiai nevelési-oktatási intézményben való tanulásukhoz,

b) a tanuló testi-lelki egészségét veszélyeztetó, tanulását akadályozó otthoni körülmények miatt szükséges.

Problémát jelent még az a pont is (5. bekezdés), mely szerint "[a] kollégium munkarendjét úgy kell meghatározni, hogy alkalmazkodjék a tanulói iskoláinak munkarendjéhez”. Ez egyértelmű primátusát jelzi az iskolai munkának, de mint láttuk, az akadémiák saját munkájukat éppen saját céljuk mentén alakítva az edzések, gyakran napi két gyakorlás, akár négy óra labdás elfoglaltság köré szervezik meg, amivel szemben gyakran másodlagossá válnak az iskolai követelmények.

A sporttörvény részletesebben meghatározza a sportiskola fogalmát, ${ }^{21}$ bár ez sem említi az akadémiát, illetve mindössze egy alkalommal, a 77. §-ban, az értelmező rendelkezések b) pontjában, a sportiskolai rendszer elemeinek felsorolásában:

m) sportiskola: az a köznevelési intézmény, jogi személy nonprofit gazdasági társaság, sportegyesület, sportvállalkozás, vagy utánpótlás-nevelés fejlesztését végzó alapitvány, amely az alábbiak szerint utánpótlás-nevelési feladatokat lát el vagy közremüködik azok ellátásában: ma) köznevelési típusú sportiskola: az a köznevelésról szóló törvény hatálya alá tartozó, évfolyamos vagy korcsoportos sportági képzést biztositó köznevelési intézmény, amely a helyi pedagógiai programját - az országos sportági szakszövetség, illetve országos sportági szövetség vagy fogyatékosok országos sportszövetségének szakmai javaslata alap-

21 2004. évi I. törvény a sportról. 
ján, az országos sportági szakszövetség, az országos sportági szövetség, vagy a fogyatékosok országos sportszövetsége és a köznevelési típusú sportiskola közötti együttmúködési megállapodásban foglaltakra is figyelemmel - sportiskolai kerettanterv alapján késziti el, és biztositja a testnevelés tantárgy emelt szintü oktatását, valamint a helyi pedagógiai programja összeállitása során figyelemmel van a sportolók felkészitési és versenyeztetési tevékenységére, továbbá a sportági programok megvalósitásával kapcsolatos felkészitéssel és versenyeztetéssel összefüggő feladatait jogi személy nonprofit gazdasági társasággal, sportegyesülettel, sportvállalkozással vagy utánpótlás-nevelés fejlesztését végzó alapitvánnyal fennálló együttmüködési megállapodás alapján végzi, mb) egyesületi jellegü sportiskola: az a korcsoportos sportági képzést biztositó jogi személy nonprofit gazdasági társaság, sportegyesület, sportvállalkozás, vagy utánpótlás-nevelés fejlesztését végzó alapitvány (utánpótlás akadémia), amely köznevelési intézménnyel, a MOB-bal, országos sportági szakszövetséggel, országos sportági szövetséggel, vagy fogyatékosok országos sportszövetségével kötött együttmúködési megállapodás alapján vesz részt az utánpótlás-nevelési feladatok ellátásban, sportolók magas szintü felkészitésében és versenyeztetésében, vagy közremüködik az utánpótlás-nevelési feladat-ellátás feltételeinek biztosításában.

A törvényben definiált sportiskola fogalmat azután pontosítja a 20/2012. (VIII. 31.) EMMI rendelet, mely szerint:

177. \$ (1) Az iskola akkor láthatja el a köznevelési típusú sportiskolai feladatot ellátó iskola (a továbbiakban: köznevelési tipusú sportiskola) feladatait, ha jogszabályban foglaltak szerint beépiti a helyi tantervébe a miniszter által kiadott kerettanterveket, továbbá eleget tesz az alábbi feltételeknek:

a) az iskola összes évfolyamán beépiti a helyi tantervébe a miniszter által a sportiskolák részére kiadott, testnevelés és sport müveltségterület tantervét,

b) az iskola pedagógiai munkája, sporttevékenységeinek szervezése során alkalmazza az adott sportág országos sportági szakszövetsége vagy országos sportági szövetsége (a továbbiakban együtt: szakszövetség) által jóváhagyott és az iskola által szabadon választott sportágak sportági tanterveit,

c) az általános iskola alsó tagozatán beépiti a helyi tantervébe a miniszter által kiadott küzdelem és játék, továbbá a sportágválasztó kerettanterveket,

d) az általános iskola felsó tagozatán beépiti a helyi tantervébe a miniszter által kiadott küzdelem és játék, továbbá a tanulásmódszertan kerettanterveket,

e) a középiskolában beépiti a helyi tantervébe a miniszter által kiadott tanulásmódszertan, továbbá a következó sportelméleti kerettanterveket: sporttörténet, testnevelés-elmélet, edzéselmélet, sportpszichológia, sportegészségtan, sport és szervezetei, sportági ismeretek.

(2) A sportiskola akkor rendelkezik a sportiskolai program végrehajtásához szükséges feltételekkel, ha a fenntartója egyetértésével kialakitotta az infrastrukturális feltételeket, és együttmüködési megállapodást kötött

a) a sportiskolai utánpótlás-nevelésben közremüködó sportegyesülettel,

b) a szakszövetséggel és

c) a központi sportigazgatásért felelós szerv szakmai szervezetével az utánpótlás-neveléssel kapcsolatos szakmai munka segitésére. 
(3) A köznevelési típusú sportiskola nem láthat el kötelezó beiskolázási és felvételi feladatokat, továbbá biztositania kell a köznevelési tanulmányok folytatását azok részére is, akik a nem megfelelő sporttevékenység vagy nem megfeleló sportbéli fejlödés miatt a köznevelési sportiskolára vonatkozó kerettantervi szabályok alapján végzett sportiskolai nevelés-oktatásban nem vehetnek részt.

(4) A köznevelési típusú sportiskolára vonatkozó kerettantervi szabályozás alapján végzett oktatásba az a tanuló vehetó fel, aki megfelel a sportegészségügyi alkalmassági és fizikai képességfelmérési vizsgálat követelményeinek és - a sportágválasztás után - a sportági szakszövetség ajánlásával rendelkezik.

(5) A köznevelési típusú sportiskola müködéséhez szükséges - a sportegyesülettel, valamint az adott sportág szakszövetségével kötött megállapodás alapján nem fedezett - többletköltségeket a fenntartónak, állami fenntartó esetében az oktatásért felelós miniszter javaslata alapján a központi költségretésnek kell biztositania.

Ezzel a koncepcióval valóban megközelítettük a sportakadémiák működésének leírását, de normatív módon nem határoztuk meg múködésüket - érdemes kiemelnünk, hogy még mindig elkerüli a rendelet szövege a sportakadémia fogalmi meghatározását is.

\section{Összefoglalás - A tapasztalt konzekvenciák a dokumentumok elemzésérôl}

Ebben az aluldefiniált jogszabályi térben működnek ma az akadémiák, holott ezzel szemben könnyen elképzelhető volna egy olyan koncepció is, amely a múvészeti tehetséggondozás intézményrendszerének törvényi meghatározásának mintáját alapul véve a sporttehetség-gondozás intézményeiről rendelkező részeket is el tudja képzelni a köznevelési törvény részeként. Ez a koncepció a tanköteles korú, vagy a tanköteles korból éppen kinövő akadémista fiatalok érdekeit egy olyan értékalapon tartja lehetségesnek képviselni, melyben az oktatásuk és nevelésük primátusa nem kérdőjeleződik meg és nem rendelhetô alá, törvényi szinten egyébként sem meghatározott sportszakmai szempontoknak. Ezek a definíciós kísérletek nagy előrelépést jelentenének abban az értelemben, hogy kizárnák a bevételmaximalizálás szempontjának közhasznúsági dimenzióját, vállalva egyrészt az elitképző, erősen szelektív működési elvet, ezzel azonban tisztázva a profilokat és célkitǔzéseket, és kivonva az akadémiákat a nyilvános viták egy erősen kétes hatású mezejéből, megkímélve őket a folyamatos önigazoló gesztusok tömegétől. Kérdéses azonban, hogy az akadémiai rendszer valóban örömmel azonosulna-e egy ilyen szándékú definíciós törekvéssel. Ez a kritériumrendszer ugyanis egyszerre lenne kellemetlen az akadémiák számára, hiszen a bevételi forrásaikat szűkítené és áttekinthetőbbé tenné a kritériumrendszereket, ugyanakkor azonban stratégiailag csak nyerhetnének vele, hiszen a hatékonyabb minőségbiztosítási rendszer működésének lehetővé válása, az akadémiák működésének átláthatóvá tétele, a számon kérhető normák egyértelműsége fokozná elfogadottságukat, és hosszú távon 
múködésük minőségét is javítaná. Azonban hangsúlyozzuk, hogy álláspontunk szerint a kritériumrendszer lényegi elemévé kellene tenni a közoktatási rendszerrel, illetve az oktatási és nevelési gyakorlattal kiépülő kapcsolatok mennyiségi és minőségi mutatóit is. És ezeknek törvényi szintű szabályozást kellene kapniuk, így a jogi környezet rendezése gondoskodhatna a fogalmak tisztázásáról, a kritériumrendszerek egyértelmúvé tételéről és ezek általános számonkérhetőségéről. Hangsúlyozzuk: a sportakadémia csak egy eleme az egyébként is nehezen áttekinthető utánpótlás-nevelési rendszernek. A magán- és alapítványi múködés a finanszírozási források bevonásához előnyös, és ezt támogatja látszólag a szabályozatlanság is. A finanszírozás elemei bizonyos állami támogatási források, melyek lehetnek közvetlen költségvetési elemek, vagy áttételesen a sportági szövetségek költségvetéséból elkülönített összegek, de idetartoznak a közvéleményben legtöbb visszatetszést keltô taoforrások, illetve ezeken túl a szülői befizetések, önkormányzati finanszírozási források, egyéb befizető gazdálkodó szervezetek, mint például egyetemek vagy vállalkozások, esetleg egyéb szponzorok és még más tényezők. Elismerjük, fontos, hogy a minősítés elemei között nagy hangsúlyt kapjanak az alkalmazott sportszakemberek szakmai képesítései, a rendelkezésre álló infrastrukturális feltételek, a tárgyi és eszközfeltételek, a megvalósítandó szakmai programok (megfogalmazott kritériumok, kitűzött célok), a múködési költségvetés terve, a sportegészségügyi, sporttudományos támogató háttér. De legalább ennyire fontosnak kellene lennie, ha az akadémista fiatalok érdekeit képviseljük, a tankötelezettség teljesítésére irányuló, esetleg szakképzési vagy egyéb továbbtanulási lehetőségeik támogatásának. Sőt nem hanyagolható el az internátusi elhelyezés körülményeinek minősége sem, beleértve ebbe a körbe a pedagógiai támogató szolgáltatásokat is. ${ }^{22}$ Tehát fontos volna, hogy legyen szó az akadémiák programjának pedagógiai elemeiről, egyáltalán jó lenne, ha az akadémiák rendelkeznének a szakmai mellett valódi pedagógiai programmal is. A köznevelési törvény szövegében történő pontos meghatározásuk ezt az elvárást elő́rhatná, ezzel emelhetné a követelményeket, de szavatolhatná a fiatalok érdekének nagyobb mértékú figyelembevételét is.

\section{Hivatkozott irodalom}

- Lehmann L. (2003). Sportiskolai rendszer szakmai koncepciója. Forrás: http://www. nupi.hu/download/sportiskola/a_sportiskolai_rendszer_szakmai_koncepcioja_ lehmann_laszlo_2003.pdf. Utolsó letöltés: 2015.11.09.

- Lehmann L. (2005). Azúj tipusú sportiskolai rendszer kiépitésének elózménye, helyzetértékelése és jövöképe. Forrás: http://www.nupi.hu/download/sportiskola/sportiskola_elemzes.pdf. Utolsó letöltés: 2015.11.09.

22 Rábai (2016) kutatása is azt támasztja alá, hogy az akadémisták jelentős része igényelné, hogy legyen lehetősége az élsport mellett egy második, tartalékterv felépítésére is az akadémiai évek alatt, ha az élsportoló karrier nem sikerülne - Rábai Dávid: Labdarúgó akadémia mint oktatási, nevelési környezet (Szakdolgozat, Debreceni Egyetem Neveléstudományok Intézete 2016. Kézirat). 
- Lehmann L. (2011). A sportiskolai rendszer, a sportiskolai típusok és formációk meghatározása és viszonyrendszere, a sportiskolák jogi és tartalmi szabályozása. Forrás: http:// www.nupi.hu/sportiskola/tanulmanyok. Utolsó letöltés: 2015.11.09.

- Rábai D. (2016). Labdarúgó akadémia mint oktatási, nevelési környezet. Szakdolgozat, Debreceni Egyetem Neveléstudományok Intézete. Kézirat.

\section{Internetes források}

- http://bcsla.hu/

- http://blafootball.hu/

- http://magyarfutballakademia.hu/

- http://puskasakademia.hu/

- http://sandorkaroly.hu/

- http://www.beneakademia.hu/

- http://www.fmla.hu/hu/

- http://www.grosicsakademia.hu/

- http://www.illesfociakademia.hu/

- http://www.szistvan.hu/foci/weblap/

- http://www.utelabdarugas.hu/

- http://www.vkla.hu/

- http://zteakademia.hu/zte/

- https://www.dvsc.hu/dla/akademia

\section{Jogszabályok}

- 1997. évi CLVI. törvény a közhasznú szervezetekrôl. Forrás: http://mkogy.jogtar. hu/?page=show\&docid=99700156.TV. Utolsó letöltés: 2016. 08. 31.

- 2013. évi V. törvény a Polgári Törvénykönyvról. Forrás: http://net.jogtar.hu/jr/gen/ hjegy_doc.cgi?docid=A1300005.TV. Utolsó letöltés: 2016. 08.31.

- 2011. évi CLXXXIX. törvény a helyi önkormányzatokról. Forrás: http://net.jogtar. hu/jr/gen/hjegy_doc.cgi?docid=A1100189.TV. Utolsó letöltés: 2016. 08.31.

- 2004. évi I. törvény a sportról. Forrás: http://net.jogtar.hu/jr/gen/hjegy_doc. cgi?docid=A0400001.TV. Utolsó letöltés: 2016. 08. 31.

- 2011. évi CLXXV. TV. az egyesülési jogról, a közhasznú jogállásról, valamint a civil szervezetek múködéséről és támogatásáról. Forrás: http://net.jogtar.hu/jr/gen/ hjegy_doc.cgi?docid=A1100175.TV. Utolsó letöltés: 2016.08.31.

- A civil szervezetek gazdálkodásáról szóló 350/2011. (XII. 30.) Korm. rendelet. Forrás: http://net.jogtar.hu/jr/gen/hjegy_doc.cgi?docid=A1100350.KOR. Utolsó letöltés: 2016. 08. 31. 
- A nemzeti erőforrás miniszter 4/2011. (II. 28.) számú rendelete az állami sportcélú támogatások felhasználásáról. Forrás: http://net.jogtar.hu/jr/gen/hjegy_doc. cgi?docid=A1100004.NEM. Utolsó letöltés: 2016. 08.31.

- 2011. évi CXC. törvény a köznevelésrőll. Forrás: http://net.jogtar.hu/jr/gen/hjegy_ doc.cgi?docid=A1100190.TV. Utolsó letöltés: 2016. 08.31.

- 20/2012. (VIII.31.) EMMI rendelet a nevelési-oktatási intézmények múködéséről és a köznevelési intézmények névhasználatáról. Forrás: net.jogtar.hu/jr/gen/hjegy_ doc.cgi?docid=A1200020.EMM. Utolsó letöltés: 2016. 08.31.

\section{Egyéb felhasznált források}

- Összefoglaló jelentés a Double Pass által készített akadémiai auditról. Debrecen Megyei Jogú Város Önkormányzatának Közlönye 2015/26. 2015. december 17. I. kötet. Forrás: http://www.mlsz.hu/wp-content/uploads/2014/06/MLSZ-AUDIT_140616.pdf. Utolsó letöltés: 2016.08.31.

- Tájékoztató a labdarúgó akadémiai licenceminősítési eljárásról. Forrás: www.mlsz. hu/wp-content/uploads/2012/10/akademiai-licenc-minositesi-eljaras-tajekoztato. doc. Utolsó letöltés: 2016. 08.31. 


\title{
A testnevelési kategóriába sorolás helyzetelemzése egy kárpátaljai oktatási intézményben
}

\begin{abstract}
Absztrakt
Ukrajnában az utóbbi 10 évben zajló társadalmi változások szükségszerűen maguk után vonták az életmód megváltozását is. Az infokommunikációs eszközök rohamos fejlődésével az életmód is rohamosan változott, a testmozgás, a sport is háttérbe szorult. A gyermekek szabad idejének mind nagyobb hányadát teszik ki a fizikailag passzív elfoglaltságok (az iskolai feladatokra fordított idő, a számítógép-használat, a televíziónézés stb.). A mozgásszegény életmód súlyos egészségügyi problémákat okoz, amelynek következménye az iskoláskorú gyermekek között előforduló gyakori elhízás (obesitas), mozgásszervi megbetegedések, a szív- és keringési rendszer betegségei.

$\mathrm{Az}$ iskolai testnevelésnek fontos szerepe van abban, hogy a tanulók rendelkezzenek a mindennapi életben is nélkülözhetetlen erőnléttel és mozgáskészségekkel. Minden gyermeknél előfordulhat azonban, hogy egészségi állapota miatt rövidebb-hosszabb időre korlátozott teljesítményre képes. Ezért a gyermekeket egészségük, az egyes elváltozások, betegségek súlyosságának megfelelően testnevelési kategóriákba sorolják.

Saját megfigyelésekből eredő konkrét adatok alapján fontosnak tartottuk bemutatni az iskolások egészségével kapcsolatos testnevelés időszerű problémáit, a testnevelési kategóriába sorolás szempontjait, valamint különböző betegségek előfordulási arányát egy kárpátaljai iskola tanulói körében.

Összességében elmondhatjuk, hogy a kutatásunk eredménye megegyezik a régiók többségében végzett kutatásokkal. Az iskoláskorú gyermekek egészségi állapota aggasztó, szükségszerú a mindennapos testnevelés bevezetése, a testmozgás, valamint a könynyített és gyógytestnevelés megszervezése.
\end{abstract}

\section{Bevezetés}

Az utóbbi évtizedekben az egész országban folyamatosan romlik a felnövekvő nemzedék egészségi állapota. Ukrajna tanintézeteiben növekvő tendenciát mutat a tanulók egészségromlása.

Az Ukrán Nemzeti Orvostudományi Akadémia adatai szerint az utóbbi tíz év folyamán az iskoláskorú gyermekek megbetegedési arányszáma 27\%-kal emelkedett. Míg az első osztályos gyerekek több mint 30\%-a már valamilyen krónikus betegség- 
ben szenved, az ötödik osztályos kort elért gyermekeknél ez az arány már 50\%, ahogyan pedig elérik a kilencedik osztályt, ez a szám már 64\% lesz. Összességében az ukrán iskolások mindössze 7\%-ánál (!) állapítható meg, hogy szervezetük funkcionális állapota kielégítő, és az iskoláskorú fiatalok csupán 30\%-a (!) sportolhat korlátozás nélkül (minisztériumi rendelet 20. 07. 2009., №518/674).

A helyzet végül is oda vezetett, hogy az utóbbi években az orvosi vizsgálatok adatai szerinti teljesen egészséges iskoláskorú gyermekek váratlanul elhaláloznak. Különösen megrendítő visszhangot váltottak ki a testnevelésiórákon bekövetkezett ilyen tragikus esetek. Nyugtalanító az a tény, hogy Ukrajnában az utóbbi nyolc évben 17 gyermek halt meg a testnevelésiórákon. Megállapítást nyert, hogy csupán egy gyermek halálát okozta a tanár szakképzetlensége, a többi haláleset oka latens (fel nem derített) betegség volt.

Ezzel kapcsolatban Ukrajna különböző régióiban egy sor átfogó egészségügyi vizsgálatot folytattak le, amelyek alapján kiderült, hogy a gyermekek és tanulók közel 90\%-ánál van kóros eltérés az egészségestől, több mint 59\%-ának nem kielégítő a fizikális állóképessége, a felnőtt lakosság majdnem 70\%-ának az egészségi állapota alatta marad az átlagnak. Ukrajnában a rokkantak száma meghaladja a 2 millió fốt. Megfigyelhető tendencia a férfiak és nők élettartamának csökkenése, jelenleg ez a mutató 10-15 évvel alacsonyabb, mint a gazdaságilag fejlett országokban (Berezsnij 2009).

Különösen veszélyes az ország jövőjét tekintve a gyermekek és fiatalok egészségi állapota és életmódja. Napjainkban minden ötödik gyermek kóros rendellenességgel születik. Az iskolások 90\%-ánál diagnosztizálnak különböző megbetegedéseket. Lényegesen gyakoribbá váltak a gyermekek tartási rendellenességei. A fiatalabb generáció körében drasztikusan növekszik a krónikus szívbetegség, a magas vérnyomás, az idegrendszeri betegségek, a csontritkulás, az ízületi gyulladás, az elhízás stb. Ez a helyzet valódi veszélyt jelent a nemzet génállománya, Ukrajna biztonsága számára, elsődleges jelentőségű állami problémává lépett elő, amely adekvát megoldást sürget („A nemzet egészsége 2009-2013 évben” állami szociális program koncepciója / Ukrajna Miniszteri Kabinetének rendelete 2008. május 21., №731-p.).

Az utóbbi tíz évben a testnevelésórák jelentős változáson estek át. Ezek a változások egy sor szomorú okra vezethetőek vissza, de ezek közül a legfőbb a gyermekek egészségének romlása. Növekedett azon gyermekek száma, akik az átlagosnál alacsonyabb szintü fizikai állapotban vannak, azoké, akik az egészségügyi mutatók alapján a testnevelési foglalkozásokon a könnyített vagy a gyógytestnevelésre utalt csoportokba sorolandók. A gyermekek többsége képtelen teljesíteni azon normákat és követelményeket, amelyeket a testnevelés átfogó programja irányoz elő.

Az egyéni tulajdonságok szerinti differenciált mozgásfejlesztés az iskolások testnevelésében hatékony módszere annak, hogy az iskolai testnevelésiórákon javítsanak az oktató-nevelő folyamaton. Az iskolai testnevelésiórákon való differenciált oktatás fó feladata abban rejlik, hogy minden egyes tanuló számára maximálisan produktív tevékenységet biztosítsanak, számukra optimális mozgási napirendet adjanak, teljes mértékben mozgósítsák képességeiket. A nemi érés, a testi fejlődés fokozatainak, a 
fokozatos terheléshez való hozzászokás jellegének figyelembevétele jelentős mértékben elősegíti az iskolás gyermekeknél a testnevelési folyamatok egyénre szabását. Az osztálykollektíva különböző testi felépítésú és fejlettségú, mozgáskultúrájú gyermekekből áll, ezért nem támaszthatunk minden gyermekkel szemben azonos követelményrendszereket. Szükség van arra, hogy feltárják a mozgáshoz való felkészültség alacsony mutatóinak okait, és hatékony utakat, módszereket dolgozzanak ki a helyzet megváltoztatására (minisztériumi rendelet 20. 07. 2009., №518/674). Ezért fontosnak tartjuk feltárni, hogyan is zajlik Ukrajnában a tanulók egészségcsoportokba sorolása, mi jellemzi ezt a folyamatot, s általánosságban hogyan épülnek fel a testnevelésórák. Tanulmányunk további célja, hogy résztvevő megfigyelés alapján bemutassa az elemi iskolai könnyített egészségcsoport gyakorlati problémáit a testnevelésiórák vezetése során. Kutatásunkhoz a témához kapcsolódó ukrán szakirodalmi források, kutatási eredmények összefoglalását és dokumentumok elemzésének módszerét választottuk.

\section{Az ukrán kisiskolások egészségi állapota}

Az egészség, mint ritka jelenség, számos tudós számára kutatási tárgy és több szempontból is górcső alá került: filozófiai, orvosbiológiai, társadalmi és pedagógiai szempontból egyaránt. Tanulmányozta a kérdést M. Amoszov, E. Vajner, V. Vojtenko, I. Muravov, H. Nikiforov, J. Liszicin. Az iskolások egészségével összefüggő folyamatok elveit dolgozták ki T. Krucevics, B. Sijan, M. Noszko, O. Dubohaj, T. Roters, Sz. Kirilenko. A felnövekvő nemzedék tartós egészségének kialakítására irányuló pszichológiai-pedagógiai folyamat orvosbiológiai sajátosságainak szentelte tudományos munkáját H. Apanaszenko és V. Volkova (Harkusa 2012).

A testnevelés jelenlegi rendszere Ukrajnában, amely arra hivatott, hogy a fó problémát, a nemzet egészségével kapcsolatos gondokat megoldja, válságban van és képtelen megfelelni a lakosság elvárásainak. Katasztrofálisan csökkent a rendszeres testedzésen és a sportban részt vevő gyermekek száma (Ripák 2009). A diákok körében végzett felmérések eredményei alapján megállapítást nyert, hogy gyakorlatilag csak minden tizedik diák egészséges, a felmérésben részt vett diákok több mint 90\%-ánál vannak bizonyos funkcionális elváltozások (Zaporozsec 2002).

Napjaink tudományos és módszertani irodalma részletesen elemzi az egészségkárosodás okait, kidolgozta az egészségjavítás útjait. Mégis az ilyen irányú törekvések dacára a diákok egészségi állapota nem lett jobb, ellenkezőleg: tovább romlott (Polatajko 2005).

$\mathrm{Az}$ iskolakezdéskor a diákok 10-20\%-ának van egészségügyi problémája, az alsó tagozatos osztályok elvégzése után pedig már a diákok 50-60\%-a érintett ebben. A vezető rendellenességek a gyermekeknél a mozgásszervekkel kapcsolatosak. A gerincferdülés, hanyag testtartás legfő́képpen az iskoláskorú gyermekek 70-75\%-ánál figyelhető meg. Tipikus iskolai probléma a rossz látás, gyakran fordul elő vegetatív diszfunkció, szívelégtelenség (Perevoscsikov 2006). 
A szakirodalom szerint az orvosi vizsgálatok eredményei alapján a megvizsgált alsó tagozatos gyermekeknek csupán 56,7\%-a számára engedélyezett a testnevelésórákon való részvétel a normál és könnyített egészségcsoportokban. A tanulás első évében gyakran jelennek meg funkcionális eltérések az iskolások egészségi állapotában. Növekszik a könnyített egészségcsoportba tartozó gyermekek száma (17,1\%-ról 48,2\%ra). Az iskolai terhelés növelésével, az új oktatási feltételekre való átmenettel együtt, ebben az életkori csoportban emelkedik a megbetegedések aránya is (Vajnbaum 2003).

E helyzet kialakulásának legfőbb oka az, hogy a tanulóknak nincs belső igényük az egészségük megőrzésére és gyarapítására, az egészséges életmód kialakítására. Az egészséges életmódra nevelés problémáját a tanároknak elsődleges fontosságú feladatként kell kezelniük az oktatási tevékenység során. Munkájukat arra kell összpontosítaniuk, hogy elősegítsék a tanulók teljes értékű fejlődését, egészségük megőrzését, fizikai képességeik fejlesztését, a test és a lélek harmonikus fejlődését (Zsuk 2010).

\section{A testnevelés kategóriába sorolás jogszabályi háttere}

A gyermekek egészségi állapotának tanulmányozása nagy jelentőséggel bír az egészségjavító intézkedések kidolgozása, majd azok segítségével az oktatás és nevelés optimális feltételeinek létrehozása szempontjából. A 2009-2010-es tanévtől kezdődően a diákok testnevelésórákon történő egészségügyi csoportokba sorolásának rendjét az Ukrajnai Egészségvédelmi Minisztérium és az Ukrajnai Oktatási és Tudományos Minisztérium által 2009. 07. 20-án 518/674. számmal jóváhagyott „A tanintézeti diákok testnevelése fölötti orvosi-pedagógiai ellenőrzés szabályzata”, illetve a „Rendelet a tanulók egészségügyi csoportokba utalásához a testnevelésórákon” c. rendeletek jelölik ki (minisztériumi rendelet 20.07. 2009., №518/674).

A szabályzat 1.2. pontja kimondja, hogy az orvosi-pedagógia kontroll elengedhetetlen a tanulók szervi funkcionalitásának, megfelelő fizikai aktivitásának, a betegségeik és sérüléseik korai jeleinek időben való felismeréséhez. A szabályzat értelmében a diákok egészségügyi állapotát az oktatási intézmény egészségügyi dolgozója értékeli és minősíti, majd a tanulók fizikai állapotának szempontjából határozza meg a megfelelő csoportokba való besorolását a testnevelésórákon. Ehhez a következő általános vizsgálatokra van szükség:

- kötelező orvosi vizsgálat (általános fizikai állapot, betegségek és fejlődési rendellenességek, traumák, akut, krónikus megbetegedések, a betegségek gyakorisága és időtartama, kóros megbetegedések felmérése);

- a fizikai terhelés adagolásával végzett funkcionális tesztek (a szervezet funkcionális állapotának meghatározása);

- egészségügyi és pedagógiai felmérések az oktatási intézmények testnevelésóráin.

A szabályzat 2. pontja meghatározza, hogy az oktatási intézmény egészségügyi dolgozója az egészségi állapotról kiállított igazolásban feltünteti a testnevelésórák azon 
csoportjait, amelyekbe a diákokat besorolja. A különböző csoportokra osztott testnevelésórák jellemzői, valamint a foglalkozások szervezésének sajátosságai a rendelet 1. sz. mellékletében van feltüntetve (minisztériumi rendelet 20.07.2009., №518/674).

A normál testnevelési csoportba az egészséges és azok a gyermekek sorolhatóak, akiknek fizikai fejlettségi mutatója magas vagy közepes szintű, illetve kardiovaszkuláris rendszerük funkcionális-tartalékos kapacitása magasabb az átlagos középszintnél vagy meghaladja azt. E csoport számára a testnevelésórák a megszabott tanterv szerint folynak, figyelembe véve a gyermekek fejlődésének egyéni jellemzőit. A fokozott fizikai terheléssel járó foglalkozásokat (sportegyesületi edzések, táncfoglalkozások stb.) a gyerekek csak alapos orvosi kivizsgálás után, az orvos engedélyével látogathatják.

A könnyített vagy rehabilitációs testnevelési foglalkozásokra azok a gyermekek járhatnak, akik akut megbetegedéseken estek át, a rehabilitációs időszakban nem igényelnek gyógytornát, valamint kardiovaszkuláris rendszerük funkcionális-tartalékos kapacitása eléri az átlagos szintet. A fizikai megterhelést fokozatosan kell emelni, az előírt normatívák teljesítése számukra nem kötelező. Nem vehetnek részt semmilyen sportegyesületi edzésen, de a fizikai erőnlét hiányosságainak visszaállítása céljából javasolják a kiegészítő gyakorlatok végzését a normál testnevelési csoportok foglalkozásain vagy otthon (egyénre kidolgozott komplex gyakorlatok, amelyek a kardiovaszkuláris rendszer kapacitásának javítására, a légutak, meghatározott izomcsoportok erősítésére, bizonyos mozgáskészségek elsajátítására vagy pontosabb végrehajtására irányulnak).

A gyógytestnevelési-csoport tanóráit azok a tanulók látogathatják, akiknek olyan jelentős, állandó vagy ideiglenes jellegú kóros eltéréseik vannak az egészségestól, amelyek nem akadályozzák óket az iskolai tanulásban, de ellenjavallt számukra a tanterv szerinti testnevelésórákon való részvétel. Az ilyen gyermekek funkcionális-tartalékos kapacitása alacsony vagy nem éri el az átlagos szintet. A fizikai felkészítés speciálisan kidolgozott program szerint történik, figyelembe véve az eltérések jellegét, valamint mértékét. A foglalkozásokat a testneveló tanár tartja, ahol egyénre szabott tornagyakorlatokat végeztet a csoport tagjaival.

A könnyített és gyógytestnevelési-csoportokba utalt tanulók folyó évi névsorát az iskolaigazgató rendelete értelmében hagyják jóvá, amit a testneveló tanárok (oktatók), osztályfőnökök tudomására hoznak (Zsuk 2010). A rendelet értelmében az osztályfőnök az oktatási intézmény egészségügyi dolgozója segítségével egészségügyi lapot állít ki, amely az osztálynaplóban található (Zaporozsec 2002).

\section{A testnevelés helyzetelemzése egy kárpátaljai iskolában}

A kötelező pedagógiai gyakorlat ideje alatt tapasztaltuk, hogy azokban az osztályokban, ahol az óráinkat vezettük, a testnevelésórákon az osztály tanulóinak közel 30\%-a a könnyített testnevelési csoportba utaltak közé tartozott. Két leánytanulónak súlyos gerincferdülése volt, bár a gyógytestnevelés mellett részt vehettek a testnevelésórán. Az osztály 22 tanulója közül 9-en csak képességeiknek megfelelő tornagyakor- 
latokat végezhettek, így a testnevelésórára való felkészülés számunkra speciális foglalkozástervezetet igényelt. A tény, hogy az alsó tagozatos osztályokban ennyire magas a könnyített és a gyógytestnevelés-csoportba utaltak száma, mint pályakezdő pedagógusokat, elgondolkodtatott. Ezek a valós tények adták az ötletet a kutatásunkhoz.

Feltételeztük, hogy az iskola többi osztályaiban kevesebb a könnyített és gyógytestnevelés-csoportokba járó tanulók száma, és a gyógytestnevelési-csoportokban kevésbé súlyos betegségben szenvedők járnak, illetve a felmentettek aránya alacsony. A kutatásunk célja végül az lett, hogy elemezzük a tanulók egészségügyi kategóriákba való besorolását az adott iskolában.

\section{Kutatási eredmények}

A kutatásunkhoz szükség volt az iskola orvosának segítségére. Mivel a tanulók a kötelező szürővizsgálat leleteit odaadták az iskolaorvosnak, ezen dokumentumok alapján a testnevelési csoportba sorolást az iskolaorvos saját megítélése szerint alkalmazta és ezt a listát a rendelkezésünkre bocsátotta. A szakorvosi szüróvizsgálat adatai alapján végeztük a kutatásunkat.

1. táblázat. A tanulók megoszlása testnevelési kategóriák szerint a 2014/2015-ös tanévben (fö/\%)

\begin{tabular}{|c|c|c|c|c|c|c|c|c|}
\hline $\begin{array}{c}\text { A } \\
\text { tanulók } \\
\text { létszáma }\end{array}$ & $\begin{array}{c}\text { Normál } \\
\text { test- } \\
\text { nevelés }\end{array}$ & $\%$ & $\begin{array}{c}\text { Könnyí- } \\
\text { tett test- } \\
\text { nevelés }\end{array}$ & $\%$ & $\begin{array}{c}\text { Gyógy } \\
\text { test- } \\
\text { nevelés }\end{array}$ & $\%$ & $\begin{array}{c}\text { Felmen- } \\
\text { tettek }\end{array}$ & $\%$ \\
\hline 456 & 298 & 65,4 & 145 & 31,8 & 11 & 2,4 & 2 & 0,4 \\
\hline
\end{tabular}

Az említett dokumentumokból szerzett információk elemzése során kiderült, hogy az 1-11. osztályos tanulók egészségügyi csoportokra tagolt testnevelésórái a következőképpen alakulnak (1. táblázat): a tanulóknak 65,4\%-a jár a normál egészségügyi csoportba, a fennmaradó 34,6\% különböző szintủ és fajtájú betegségben szenved. Ennek megfelelően a könnyített testnevelésre 31,8\%, valamint a gyógytestnevelésre 2,4\% jár. Súlyos egészségi állapotuk miatt a tanulók 0,4\%-a teljesen fel van mentve a testnevelésórák alól.

2. táblázat. Az iskola tanulóinak egészségügyi csoportok szerinti megoszlása (fö/\%)

\begin{tabular}{|c|c|c|c|c|c|c|c|c|c|c|c|c|}
\hline \multicolumn{4}{|c|}{ 1-4. osztály } & \multicolumn{5}{|c|}{ 5-9. osztály } & \multicolumn{4}{|c|}{ 10-11. osztály } \\
\hline 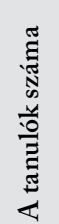 & 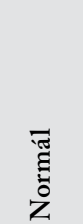 & 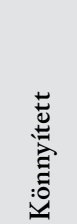 & 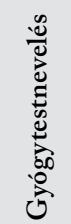 & 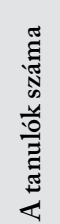 & $\begin{array}{l}\overline{\widetilde{J}} \\
\text { है } \\
\text { z }\end{array}$ & 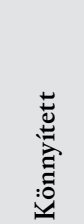 & 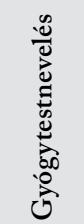 & 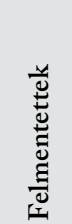 & 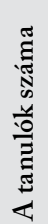 & 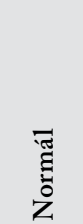 & 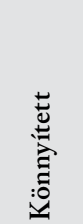 & 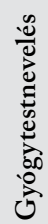 \\
\hline 192 & 121 & 68 & 3 & 174 & 88 & 76 & 8 & 2 & 90 & 69 & 21 & - \\
\hline & $63,1 \%$ & $35,4 \%$ & $1,5 \%$ & & $50,5 \%$ & $43,7 \%$ & $4,5 \%$ & $1,3 \%$ & & $76,6 \%$ & $23,4 \%$ & - \\
\hline
\end{tabular}


Évfolyamok szerint az iskola testnevelési egészségügyi csoportosítása az alsó tagozatban a következő: $63,1 \%$ a normál csoportba jár, 35,4\% a könnyített testnevelésre és 1,5\% gyógytestnevelésre jár. A felmentettek száma 0 (2. táblázat).

Az általános iskolások, tehát az 5-9. osztályosok testnevelési csoportbesorolásának megoszlása a következő: normál testnevelésre a tanulók 50,5\%-a jár, könnyített testnevelésre 43,7\%-a, gyógytestnevelésre 4,5\%-a és a testnevelés alól felmentettek 1,3\%. Két tanuló az állandóan felmentett kategóriába került súlyos gerincdeformitása miatt, kórházi gyógytestnevelésben, rehabilitációban vesz részt.

A középiskolások mutatója megcáfolja feltételezéseinket, mivel a könnyített testnevelési kategóriába a tanulók mindössze 23,4\%-a jár. Ez azzal magyarázható, hogy az általános iskola elvégzése után a tanulók többsége szakiskolákat választ további tanulmányaihoz. Ennek következtében a felső osztályok összetétele megváltozik. A 10-11. osztályokba új tanulók érkeznek, akik az érettségi megszerzésével a felsőoktatásban folytatják tanulmányaikat.

3. táblázat. A könnyített, a gyógytestnevelés- és a felmentett csoportba utalt tanulók szervi elváltozásai a normál egészségi állapottól (fö/\%)

\begin{tabular}{|c|c|c|c|c|c|c|}
\hline 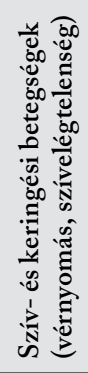 & 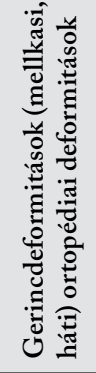 & 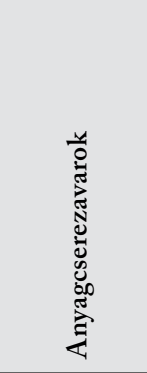 & 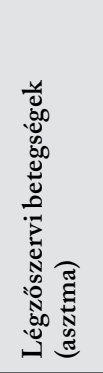 & 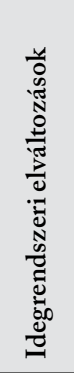 & 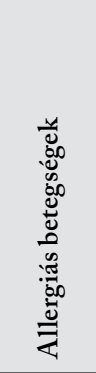 & 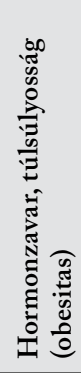 \\
\hline 36 & $51+2$ & 14 & 9 & 18 & 31 & 17 \\
\hline $20,2 \%$ & $29,8 \%$ & $7,9 \%$ & $5,0 \%$ & 10,1 & $17,4 \%$ & $9,6 \%$ \\
\hline
\end{tabular}

A harmadik táblázatban a könnyített, a gyógytestnevelés- és a felmentett csoportba járó tanulók száma, valamint szervi betegségei, elváltozásai vannak feltüntetve. Az adatsorból kitúnik a tartási problémák gyakori előfordulása (29,8\%). Ez azt jelzi, hogy a gyermekek izomzatának fejlettsége nem éri el az optimális szintet. Igaz, a tanulók többsége nem igényel ortopédiai kezelést, kivéve két tanulót, de figyelembe kell venni, hogy ezek a deformitások súlyosbodhatnak, illetve másodlagos deformitások jöhetnek létre.

A vizsgált iskolában a második helyen a szív és a keringési rendszer betegsége áll (20,2\%). Sajnos már gyerekkorban kialakul a magas vérnyomás, szívelégtelenség, cukorbetegség és veleszületett krónikus betegségek. Korábban szinte kizárólag az idôs emberek betegségei voltak ezek, de sajnos napjainkban előfordulásuk egyre fiatalabb korban figyelhető meg. Kialakulásukban szerepet játszik az egészségtelen életmód, a helytelen táplálkozás, a mozgásszegény életmód. 
$\mathrm{Az}$ adatfeldolgozás alapján megállapíthatjuk, hogy a testnevelő tanárok helyzete nem irigylésre méltó. A vizsgált középiskolában a tanulók 39\%-a (178 tanuló) kizárólag egyéni, differenciált oktatásban részesülhet, vagyis osztályonként átlagosan a tanulók 30\%-a. A másik szembetűnő adat a könnyített testnevelési kategóriába besorolt tanulók magas száma. A vizsgált szakorvosi vélemények alapján ezek a tanulók a tanévet eleve fiziológiai hátránnyal kezdik, és a koruknak megfelelő, fokozatos terhelésben nem vehetnek részt, ami később lemaradást okoz a testi fejlődésükben.

\section{Következtetések}

Az iskolában végzett vizsgálatok eredményeiből arra következtethetünk, hogy az általános iskola tanulóinak egészségi állapota az oktatás folyamatában fokozatosan változik. Az adatok bizonyítják, hogy egyre több gyereknek van szüksége gyógytestnevelésre. El kell ismerni, hogy a tanulók egészségi állapotának és mozgásaktivitásának fejlesztésére nemcsak a testnevelésóra szolgál, hanem be kell iktatni az iskolában, tanórán kívüli idôbe, azokat a rekreációs foglalkozásformákat is, amelyek tartalmaznak reggeli gimnasztikai gyakorlatokat, tornaperceket, különböző mozgásos játékokat a szünetekben, a napközis foglalkozásokon be kell vezetni a rendszeres testnevelést, a tömegsportmozgalomban való részvétel népszerúsítését.

Rendkívül fontos az egészségügyi és pedagógiai szakemberek együttmúködése, mivel a testnevelés bármely formája csak az egészségügyi és a pedagógiai team szoros együttmúködésével lehet eredményes. Ez az együttmúködés ideális esetben kiterjed a pedagógiai szakszolgálatnál dolgozó gyógytestnevelő, a testnevelő, az egészségügyben dolgozó gyógytornász közötti szakmai együttmúködésre is. Az együttmúködést javítja, ha az iskola-egészségügyi szakemberek tapasztalatszerzés végett látogatják a testnevelés- és gyógytestnevelési-órákat. Különösen szükség van erre a kategóriaváltáskor és olyan esetekben, amikor az iskolaorvos és a kezelőorvos véleménye eltér egymástól. Folytatni kell a rendszeres szürővizsgálatokat, mert ezek segítségével időben fel lehet ismerni a betegségeket, elváltozásokat. Meg kell teremteni azokat a lehetőségeket, amelyek biztosításával a fiatalok maguk is képesek lehetnek egészségük megőrzésére. Ehhez szükséges a rendszeres mozgás, a megfelelő táplálkozás és az egészséget károsító magatartásformáktól való tartózkodás (dohányzás, alkohol- és drogfogyasztás).

A kutatás további irányvonalát képezi a jövőbeli betegségek megelőzésében, a társadalmi-gazdasági és szociális tényezők javításán túl, a gyermekek nevelése arra, hogy hogyan éljenek egészségesen, miként mozogjanak eleget. A cél pedig az, hogy a gyerekekben pozitív hozzáállást alakítsunk ki az egészséges életmód iránt. 


\section{Hivatkozott irodalom}

- Berezsnoj, V. V. \& Marusko, T. V. (2009). Внезапная смерть при физических нагрузках у детей и подростков [A gyerekek és serdülők hirtelen halála a fizikai terhelés következtében]. Modern Pediátria, (6), 29-34.

- Harkusa, Sz. V. (2012). Медико-педагогічний контроль розподілу учнів на медичні групи для занять фізичною культурою у загальноосвітніх навчальних закладах [A középfokú tanintézetek tanulóinak orvosi-pedagógiai kontrollja, valamint a tanulók egészségügyi kategóriákba való besorolása]. II. kötet. Csernyigov, Csernyigovi Nemzeti Pedagógiai Egyetem.

- Perevozcsikov, J. A. (2006). Профилактика и коррекция функциональных отклонений у школьников : монография [Az iskolások funkcionális eltérésének megelózése és korrekciója]. Odessza, Juridicsna literatura, Odesszai Nemzeti Jogász Akadémia.

- Vajnbaum, J. Sz. (2003). Гигиена физического воспитания и спорта : учеб. пособие (для студ. высш. пед. учеб. заведений) [A testnevelés és sport higiéniája: tankönyv (felsőoktatási intézmények hallgatói számára)]. Moszkva, Akadémia Kiadó.

- Zaporozsec, A. V. (2002). Стан здоров’я населення України [Ukrajna lakosságának egészségi állapota]. In Zaporozsec, A. V. (ed.). Здоровий спосіб життя : зб. матеріалів II Міжрегіон. наук.-практ. конф. [Egészséges életmód. Tanulmánykötet a II. regionális tudományos konferenciáról] (pp. 31-33). Lviv.

- Zsuk, G. А. (2010). Аналіз підходів до розподілу учнів на медичні групи для занять фізичною культурою у загальноосвітній школі [Középiskolás tanulók testnevelési egészségügyi csoportokba való besorolásának elemzése]. A testnevelés és sport pedagógiai, pszichológiai és orvosbiológiai problémái, (1), 61-63.

\section{Dokumentumok}

- „A nemzet egészsége” 2009-2013 évben állami szociális program koncepciója / Ukrajna Miniszteri Kabinetének rendelete 2008. május 21., №731-p. / Forrás: http://zakon2.rada.gov.ua/laws/show/731-2008.

- Az oktatási intézmények tanulóinak orvosi ellenőrzésének megszervezése / Ukrajna Egészségügyi Minisztériumának és Ukrajna Oktatási és Tudományos Minisztériumának rendelete 2009. 07. 20., №518/674. Forrás: http://zakon2.rada.gov.ua/ laws/show/z0772-09.

- „A tanulók egészségügyi csoportokba való beosztása a testnevelési foglalkozásokon” / Ukrajna Egészségügyi Minisztériumának és Ukrajna Oktatási és Tudományos Minisztériumának rendelete 2009. 07. 20., №518/674. Forrás: http://zakon2.rada. gov.ua/laws/show/z0773-09.

- Módszertani útmutatók a testnevelés oktatásához a 2011/2012. tanévben / Testnevelés az iskolában - № 4. - 2011. 



\section{FEJEZET}

A testnevelés és a sport értékteremtő és -átadó szerepe 



\title{
Bodnár Ilona, Perényi Szilvia
}

\section{Értékháló az iskolai testnevelés körül}

\begin{abstract}
Absztrakt
A mindennapos iskolai testnevelés bevezetésének az ifjúság fizikai állapotának javítása mellett fontos szempontja volt az, hogy a sport szociális és morális értékképviselete hozzájáruljon az ifjúság fejlesztéséhez. Mindemellett azonban az iskolai testnevelés körüli értékhálónak meghatározó szerepe van abban, hogy a tanulóknak milyen élményeik, tapasztalatuk lesz a mozgásról, a mozgás öröméről. Vagyis arról, hogy jó-e a sport számukra vagy rossz, egy adott sportág, mozgásforma képvisel-e számukra értéket vagy nem. Az értékek közvetlen transzferálhatósága, az egész életen át fenntartható sportos, aktivitásban és mozgásban gazdag életmód kialakítása és az átadás automatizmusa kerül a figyelem központjába. Jelen írás a mindennapos testnevelés bevezetése kapcsán társadalomtudományi elméletek segítségével, valamint nemzetközi és hazai kutatási eredmények felhasználásával próbál a fenti kérdésekre válaszokat keresni és gyakorlati hidakat képezni.
\end{abstract}

\section{Bevezetés}

A legnagyobb nemzetközi kulturális események, rendezvények a sporthoz kapcsolódnak: az olimpiai játékok és a labdarúgó világbajnokság vonzza a legtöbb nézőt és érdeklődőt világszerte. A sportrendezvényekre fordított személyes és állami figyelem, a siker érdekében felhasznált idő, pénz és energia azt is sugallják, hogy a sportolás, a mozgás széles körben elfogadott, magas társadalmi presztízzsel rendelkező, a nemzeti kultúráktól független értékeket képvisel. Röviden: a sport jó és hasznos.

A sportolás, a testedzés hosszú ideje preferált magatartás. A kötelező iskolai testnevelés bevezetésének is igen fontos szempontja volt az a felfogás, hogy a sport sokoldalúan járul hozzá az ifjúság fejlesztéséhez. A sportok mind kidolgozottabbá váló szabályrendszere lehetőséget nyújt a fegyelmezésre, a felelősségvállalás megtanulására, a közösségben való gondolkodás elsajátítására. Ez a felfogás még nagyobb teret kap az individualizálódó, de egyben egyre több veszélyt, rizikófaktort is rejtő életmódok terjedésével (Beck 2003). Nemcsak a sportlobbi, de a szülők is szívesen tekintenek a sportra, mint a drog, az alkohol, az erőszak, a bűnözés elleni védekezés hatékony eszközére. Ahogy Jay Coakley (2011) fogalmaz a sportevangélisták nézeteivel kapcsolatban, a sportnak kettős funkciója van: őrangyal szerepe van a védekezésben, a megelőzésben; és autómosóként működik, ha már baj van. A veszélyeztetett, különösen nagy kockázati tényezőjű fiatalokat a sportolás megtisztítja, át- és lemossa róluk 
a társadalomra nézve káros személyiségvonásokat. A sport alapvető ideológiája, hogy szociális és morális fejlődés, pozitív változás érhető el általa. Ez a felfogás automatizmust, biztos sikert tükröz, mintha az értékek közvetlenül átadhatók, átvehetők transzferálhatók lennének.

\section{Sportértékek differenciálódása}

A XX. század folyamán a sport általánosan elfogadott, a társadalom egészére kiterjedő jelenséggé vált. Ennek eredménye nemcsak a sportágak szélesedő körében mutatkozik meg, hanem abban is, hogy funkció- és értékrendszere is differenciálódott. A társadalom vertikális és horizontális tagolódásának megfelelően az egyes társadalmi csoportok a saját életükre, szükségleteikre és lehetőségeikre szabták át az egyes mozgásformákat (Borudieu 1996; Coakley \& Pike 2012). A sport felépítése, szervezeti rendszere is megváltozott: a kezdeteket tükröző, egy tömböt képező piramismodell helyébe több elemből álló elképzelések léptek (De Bosscher et al. 2010; Scheerder et al. 2011). Ezeket a szerkezeti változásokat a mozgásformák, és rajtuk keresztül az értékek felől közelítette meg Eichberg (2009), amikor elkészítette az alábbi felosztást:

- a versengés és a teljesítmény sportja;

- a (ön)fegyelmezés és az integrálás sportja;

- a találkozások és a kapcsolatok sportja.

Sportban járatos szakembernek sem kell lenni ahhoz, hogy Eichberg hármas tagolásához szervezeti kereteket, múködési formákat rendeljen valaki. Az egyes elemek rövid áttekintésénél azonban inkább az értékek hangsúlyozására törekszünk.

A versengés és a teljesitmény sportja (sport for sport's sake) erőteljesen szabályozott, formalizált. A sportolás célja, hogy elsajátítsuk, hogyan kell játszani az adott sportágat, és a keretek ismeretében hogyan kell nyerni. Győzelemre és kiválóságra törekvés jellemzi a résztvevőket, ami mindig másokkal történő összevetést, társadalmi megmérettetést jelent. Ennek megfelelően az értékek is kettős indíttatásúak. A sporttevékenység élvezete, a komplex mozgáskészség elsajátítása, a magas szintű gyakorlottság megszerzése személyes, belső értékeknek számítanak. A győzelem után járó jutalom, elismerés, dicsőség külső értékek. A sport ezen formájában a személyes és a társadalmi értékek egyaránt megjelennek, mindkettőnek fontos szerepe van a részvétel motiválásában.

A fegyelmezés és az integrálás sportjában (sport for good) a ,jóság/jószág” társadalmi, közösségi értékek jelenlétére utal. A hívószavak, az értékek: társadalmi kohézió, befogadás, egészségfejlesztés, jóllét, gazdasági hasznosság stb. Ezek köszönnek vissza például az Európai Unió által kiadott Fehér könyv a sportról (2007) iránymutatásaiban is. A sportolás társadalmi és gazdasági ,jószág” jellege arra is utal, hogy itt közösségi, az állam, a kormányzati szervek által képviselt értékekről van szó. Az egyes szakpolitikákban - sport, egészség, oktatás, szociálpolitika - deklarált célértékekről. 
A találkozások és a kapcsolatok sportjában (sport for all) tisztán jelennek meg a személyes, az egyéni értékek. Itt nem kombinálódnak közösségi értékekkel, mint a versengés és a teljesítmény sportjában. Fontos hangsúlyozni, hogy az idetartozó sportolási formák nem csak a szabadidősportot, az informális keretek között zajló sportolást jelentik. Szervezett keretek, irányított formák között is megvalósulhat.

$\mathrm{Az}$ iskolai testnevelés mindhárom sportolási formához kapcsolódhat, így helye alapvetően attól függ, milyen funkciót, milyen célt és értéket szán az adott társadalom és politikai rendszer a tantárgynak. $\mathrm{Ha}$ az iskolai testnevelésre mint a versenysport utánpótlás-nevelésének eszközére tekintünk, akkor az első csoporttal lesz szoros kapcsolatban. Erre példa a hazai sportiskolai rendszer kiépítése, a tehetségirányítás. Ha szélesebb, a társadalom egészét érintő problémákat és értékeket tartanak szem előtt a szereplők, akkor a másik két sportolási forma kerül előtérbe az iskolákban.

Mindezekből kitűnik, hogy az iskolai testnevelés értékrendszerének alakítása soktényezős, sokszereplős, többlépcsős folyamat. Ezt a folyamatot, egyén és közösség, egyén és az őt körülvevő szúkebb és tágabb környezet kölcsönös egymásra hatásaként is felfoghatjuk. A környezet esetében a makroszintú, országos politika által elindított kezdeményezések módosulhatnak a közvetlen környezet hatására. A lokális sportolási lehetőségek, az iskola, a testnevelő tanár, a szülők mind olyan döntéshozók, akik újabb elemeket, más hangsúlyokat emelhetnek be a rendszerbe. Jelenbeli szerepük egyáltalán nem elhanyagolható, de a tantárgy történetét nézve ez nem mindig volt így.

\section{Az iskolai testnevelés története értékek mentén}

Ahogy az előző fejezetben említettük, a sport XX. századi történetét a kiszélesedés, a sportágai és társadalmi bővülés jellemezte. Hasonló jelenségeket figyelhetünk meg az iskolai testnevelésben is. Kirk (2011) a tantárgy történeti áttekintésében a demokratizálódást hangsúlyozza: társadalmi osztályok, rétegek és sportágak, mozgásformák tekintetében. A múlt század elején a fegyelmezett, munkára és harcra alkalmas test áll a középpontban, ami a fiúk nevelésében kap nagy hangsúlyt. Éppen ezért a tantárgy alapvetően a gimnasztikára épül. A kívánatosnak tartott értékek és célok változását jelzi a hazai torna-atlétika vita, illetve a csapatjátékok, labdajátékok megjelenése. A fegyelmezettség, a teherbírás, az állóképesség mellé felzárkózik a kreativitás, az együttmúködés - versengés, a játékokon keresztül a spontaneitás. Vagyis a közösségi értékek mellé beemelődnek az egyén számára fontos értékek. Ennek a fordulatnak a hátterében a gyermekközpontú nevelés megjelenése, a gyermeklélektan oktatásban való alkalmazása is áll (Donáth 2007). A múlt század elejének másik nagy társadalmi áramlata a nők emancipációja. A társadalmi kiszélesedés fontos eleme a lányok testnevelésének a kérdése. A tantárgy számukra is kötelezővé válásával úgynevezett nőies értékek kerülnek be az oktatásba: esztétikusság, hajlékonyság (Bodnár 2007). A demokratizálódás egyben az esélyek kiegyenlítődését is jelenti: a mindenki számára kötelezővé váló oktatás egyre szélesebb mozgásrepertoárt, sportolási formát nyújt a gyerekeknek. 
Eichberg felosztásához visszatérve az iskolai testnevelés a fegyelmezés és az integrálás sportjának indult, amiben fontos szerepet játszott, hogy a sport és a testnevelés politikailag, ideológiailag semleges terület látszatát kelti, ahol a közvetett, éppen ezért bizonyos tekintetben sokkal hatékonyabb értékközvetítés valósulhat meg. A sportági szélesedés, a „sportifikáció” és a sport (nemzetközi) politikai presztízsértékének a növekedése a versengés és a teljesitmény sportjának előtérbe kerülését eredményezte hazánkban is. Az előző történeti áttekintés gondolatmenetét követve most a harmadik, a személyes értékeket hordozó találkozások és kapcsolatok sportja megjelenésének kellene következnie. Az elmúlt években bekövetkezett hazai tantárgyi változások, a mindennapos testnevelés bevezetése lehetőséget is nyújtana erre, de az oktatás- és a sportpolitikai narratíva ismételten a ,jószág” jelleget hangsúlyozza: egészségfejlesztés, jóllét, életen át való sportolás stb. Háttérben maradnak a személyes értékek, amelyek pedig sokkal inkább kapcsolódnak az oktatás általános célkitüzéseihez, az iskola által képviselt értékrendszerhez: önbecsülés növelése, megküzdési stratégiák elsajátítása, társadalmi felelősségvállalás. Ezen értékek jobb kommunikálásával talán kevesebb akadályt, ellenállást kellett volna leküzdeni a megvalósítás során.

Ezzel elérkeztünk az iskolai testnevelés - nem csak honi - legnagyobb kihívásához: a személyes értékek figyelembevételéhez, a rendszer mozgatóelemei közé történő beemeléséhez. Ez nem kizárólag a testnevelés tantárgy problémája, hanem az oktatás egészét érintő kérdés. Az elmúlt időszak egyik válasza erre a kérdésre az élménypedagógia megjelenése, illetve a megélénkülő kutatói érdeklődés az érintettek, a gyerekek oktatással, tantárggyal kapcsolatos értékvizsgálata iránt. Pontosabban a mozgás, a sportolás irányában végzett kutatások, mert esetünkben a szabadon választott sportolás, ami nem csak iskolai keretek között valósulhat meg, több figyelmet kap. Az erre a területre vonatkozó sokkal kimunkáltabb kutatásmódszertan oka a már említett szabad választás, így az egyéni motivációk dominanciája mellett, a versenysportnak az iskolai testneveléstôl magasabb társadalmi és gazdasági presztízse.

\section{A mozgás öröme}

A sport, különösen a versenysport világa a felnőttek által konstruálódik, alapvetően ennek az életszakasznak az értékei társulnak hozzá. Így amikor fiatalokat, gyerekeket kérdeznek a sporttal kapcsolatos értékeikről, akkor ezt a tényt is figyelembe kell venni. Az életkorból adódóan más lehet az értékek rangsora, szerkezete is, mint a felnőtteké. Ilyen eltérést mutattak ki Lee és munkatársai (2013) is angol fiatalok esetében. A felkínált 18 értékből a rangsor első három helyére az élvezet, a teljesítmény és a sportszerüség került. Míg a legutolsó a győzelem volt. A versenysportra a belső, személyes és a külső értékek egyaránt jellemzők, de a fiataloknál a belső értékek dominálnak. Ezek közül is meghatározó számukra a mozgás öröme. Teljesen érthetően, személyiségfejlődésük szakaszának megfelelően a külső, eszközjellegű értékek alárendelődése a belsőknek. A lányok esetében még inkább a belső értékek dominálnak. 
Mindaddig nem is okoz ez értékkonfliktust, amíg a környezet elfogadja életkorukat, megengedi nekik, hogy gyerekek legyenek, „gyerekes” értékekkel.

Hazai és nemzetközi értékkutatások is azt jelzik, hogy a belső értékek, leginkább a mozgás öröme a meghatározó a testmozgással, a sportolással, a testneveléssel kapcsolatban. Azokat az univerzális, átfogó, felnőttek számára fontos értékeket, amelyeket a tantervek, az iskola és a tanárok közvetítenek, nem tekintik sajátjuknak, nem tudnak velük azonosulni. A rendszer által elérni kívánt és a gyermekekben működő, döntéseiket befolyásoló értékek nincsenek egyensúlyban. Ez a disszonancia nem ismeretlen a testnevelő tanárok előtt sem. A kutatók - többek között Pringle - egy másik ellentmondást is látnak: „...számos sportpedagógiai koncepció felismeri a mozgás öröm szerepét az iskolai testnevelés folyamatában, azonban csak kevés ismeri el azt hatékony személyiségformáló értékként és annak oktatás-módszertani eszközként való kiemelését..." (Pringle 2010: 119).

Az ifjúsági populációk esetében ez a felnőttektől eltérő értékvilág egyértelműen az élménycentrikus, posztmodern értékek felé tolódik el, mely trendeket nemcsak hazai, de nemzetközi nagymintás értékkutatások is igazolnak, speciális jellemzők kiemelésével a hazánkhoz hasonló átalakulásokon átment országokra vonatkozóan (Inglehart \& Baker 2000; Schwartz et al. 2000). Schulze (2000) élménytársadalomról beszél, melyben hangsúlyozódik az autonóm döntés, a választás szabadsága, valamint az élmény és változatosság keresése. Ezek az értékek megjelennek az egyéni életutakban, de közéleti és politikai irányultságokban is, és tetten érhetők az emberi test megalkotásában és megjelenítésében is. Éber (2008) szerint az élménytársadalmi jellemzők a magyar társadalomban is tetten érhetők. Bauer (2002) pedig a magyar ifjúság körében posztmodern eltolódása során a barátság, az érdekes élet, a szerelem és a kreativitás értékeinek felértékelődését jelezte.

A gyerekek esetében megfigyelt mozgásörömértékek a serdülőkort követően mozgásélményértékekké való konvertálódását figyelhetjük meg. Az ifjúságvizsgálat adatai az új évezred első évtizede során többször is igazolták, hogy az iskolai testnevelésen kívüli, többségében informális sportban rendszeresen részt vevő 15-29 éves populáció értékrendje az országos átlaghoz képest még inkább magán hordozza a posztmodern értékek preferenciáit (Perényi 2010a; 2010b). A rendszeresen sportolók nem sportoló társaikhoz képest fontosabbnak ítélték meg az érdekes és változatos élet, a barátság, a kreativitás értékeit. Ebben az értékváltási folyamatban az élsport kitartást, lemondást, késleltetett eredménymegélést, kemény küzdelmet jelentő környezetétől a fiatal populációk vélhetően a kisebb befektetést, könnyebb megtérülést és közvetlen élmény-kielégülést kínáló amatőrverseny vagy szabadidősport felé terelődnek. A társadalmi értékváltási folyamatok tehát az informális és/vagy közösségi szabadidősport térhódítását segítik, ennek a folyamatnak lehetünk szemtanúi. Az élsport csúcseredményeinek elismerésében, követésében a fiatalok a világversenyek szurkolótáboraiban és önkénteseinek tömegeiben keresik az ismételten élményszerű bekapcsolódást.

Skille (2005) a skandináv ifjúsági populációk esetében a klasszikus sportolási formák mellett az újszerű, alternatív mozgásformák terjedéséről számol be. Scheerder 
és Breedveld (2004) felvetik a szervezett, egyesületi kereteken belül múködő sport európai válságát, melyet az egyesületi tagság csökkenő száma jelez a nyugat-európai országokban is. Hazánkban az élsport és a szabadidősport közötti, a nyugat-európainál élesebb szerkezeti, múködési és értékrendbeli elhatárolódás kiegészül a felnövekvő ifjúsági populációk posztmodernitás felé haladó értékszemléletével és a sportolás körülményeihez, illetve feltételeihez kapcsolódó elvárások és igények változásával (Perényi 2010c). Ez az összetett hatásmechanizmus, ennek különböző elemei magyarázhatják a sport különböző szintjein érvényesülő továbbra is alacsony részvételi arányokat (Perényi 2011).

\section{Értékközvetítés}

Az értékek távolsága nagymértékben megnehezíti a közvetítést, a gyerekek értékrendszerének alakítását. A testnevelés, a mozgás tekintetében a testnevelő tanárok és az edzők szerepét szokták kiemelni. Mielőtt azonban az ő tevékenységüket elemeznénk, lépjünk egy kicsit hátrébb, az iskolához. A londoni olimpia után készült egy kutatás, amelyik azt vizsgálta, hogy a brit olimpikonok milyen iskolai háttérből érkeztek. Az alapítványi, a független iskolák sikeresebbek voltak a bajnokok nevelésében az állami intézményekhez képest. Pedagógiai programjukban és ennek megfelelően a sportolási lehetőségek biztosításában is nagyobb figyelmet fordítottak erre a területre. E mögött persze marketingmegfontolások is vannak, hisz egy eredményes, híres sportoló nagy vonzerőt jelent a toborzásnál, a fizetőképes tanulók szüleinek megnyerésénél. Tehát ha a tanárok értékközvetítő munkáját akarjuk megítélni, feltétlenül fontos az iskola vezetésének, a helyi nevelési programnak a tartalmát megvizsgálni.

Freeman és munkatársainak (2013) vizsgálata a sportértékek közvetítése szempontjából fontos személyek, intézmények kérdéskörére terjedt ki. Az angol iskolások rangsorában az első három helyet az edző, a sportklub és a barátok foglalják el. Az iskola és a testnevelő tanár a hatodik és a hetedik helyen szerepel. Az okok között feltehetően szerepel az is, hogy az edzők, a sportklubok, az ottani tevékenység keretében az univerzális, átfogó értékeket sikeresebben fordítják át, mutatják meg személyes szinten, az egyén számára fontos értékek felmutatásával. Gyakorlatiasabban, az adott korosztálynak tisztábban, érthetőbben jelennek meg a pozitívumok, az értékek. Ugyanakkor az edzőknek változatosabb helyzetekben, nem előre megszabott formai és idôbeli keretek között kell múködniük, így lehetőségük adódik egy-egy szituáció értelmezésére, nem csak a személyes példamutatásra kell hagyatkozniuk.

Az edzők kiemelt értékközvetítő szerepének másik magyarázata, hogy az Eichbergféle felosztás szerint a tevékenységi területükön az egyéni értékeknek alapvetô szerepe van. Amíg a versenysport egyik mozgatórugója az egyéni érdek, addig a testnevelés a másokkal közös, szociális értékeket hangsúlyozza. Egy közösségi értékrendszerben kellene a testnevelő tanárnak differenciálni: sportágtól, körülménytől és résztvevőktől függően, de mindezekhez alkalmazkodva megmutatni és felmutatni a mozgás öröm- 
értékét. Olyan mozgásformát találni a gyerekek számára, amit majd felnőttkorukban is használnak. Mindezekben a gyerekek hosszú távú érdeke jelenik meg, ami nem feltétlenül esik egybe a jelen oktatási-nevelési rendszer szükségleteivel. Ezeknek az értékkonfliktusoknak a feloldását a magyar sportrendszer, sportpolitika sem támogatja. Részben a szabadidősport, a fiatalokra jellemző informális sportolás alacsony finanszírozása, részben a nem versenyjellegü, de szervezett keretek között folyó amatőr sportolási formák hiánya miatt (Perényi 2013). Nemcsak értékek tekintetében van távolság az iskolai testnevelés és a versenysport között, hanem strukturális szempontból is.

\section{Jó sport - rossz sport}

A mindennapos testnevelés megalapozó szereppel bír az egész életen át fenntartandó és fenntartható sportos, aktivitásban és mozgásban gazdag életmód kialakításában. Az iskolai évek alatt olyan kompetenciák elsajátítása válik hangsúlyossá, melyek a formális oktatás elhagyása után az egyén számára átkonvertálhatóvá válik és beépíthető a mindennapi élettevékenységek közé. A rendszer értéke hosszú távon akkor térülhet meg, ha a sportból való elvándorlás jelenlegi töréspontjainál, mint például az oktatási rendszerből való kikerülés, munkába állás vagy korosztály, életszakasz, a mozgásos életmód folytatásához vagy az ismételt bekapcsolódáshoz rendelkezésre áll egy olyan kínálati portfólió, mely a különböző igénycsoportokat kiszolgálja. Ez a kínálati háló nem tartalmazhat kizárólag fogyasztói ajánlatokat. A sport alapvetően társadalmi jelenség, pillérei a sportegyesületek (Perényi \& Bodnár 2015). Ezekben az egységekben a mozgásos tevékenységeken kívül közösségek alakulnak, a sportban és a sport világán kívül is alkalmazható kompetenciák, értékek közvetítődnek. A sportegyesületek szerepe az értékszocializációban (Perényi \& Bodnár 2015) és a társadalmi jóllét alakulásában tehát megkérdőjelezhetetlen (Kovács \& Perényi 2014). A sport rendszere akkor lesz jó, akkor lesz rendszerszinten jobb, ha a magas részvételi rendszerek, mint például az iskolai testnevelés és az alacsonyabb részvételi arányokat maguknak tudható rendszerek, mint például az egyesületi sport között az egyén számára átmeneti hidak alakulnak ki. Továbbá az egyesületi sport rendszerén belül a versenyeredmények által nem befolyásolt megtartó hatás érvényesül, vagyis a sportegyesület a sport teljes spektrumában tud a különböző korosztályok és képességi szintek számára mozgásos lehetőségeket, illetve közösségi részvételt ajánlani. Tehát az igényszintek szerinti differenciálás és differenciálódás, valamint az átjárási lehetőségek biztosítása a sportban rendszerszinten érvényesül.

$\mathrm{Az}$ iskolai testnevelés körüli értékhálót intézmények, szervezetek és személyek szövik, néha egymással együttmúködve, de az is előfordul, hogy egymásnak feszülve, értékkonfliktust okozva teszik ezt. A változásokhoz, a tantárgy oktatásának demokratizálódásához szükség van az értékek ütközésére, ütköztetésére. Illetve arra, hogy az érintettek, a tanulók értékrendszerét, annak hierarchiáját minél pontosabban megismerjük, feltérképezzük: megtudjuk, hogy döntéseikben, cselekvéseik irányításában 
melyik játssza a legfontosabb szerepet. A feltérképezendő értékrendszerről azonban tudni kell, hogy változik, több tényező is hatással van rá. Ezek közül a legfontosabb az életkor - és ehhez kapcsolódóan a tanulók esetében a kortársak, a társadalmi nem, az adott sportág típusa és a sportág gyakorlásának színvonala. Ezeknek együttesen van meghatározó szerepe abban, hogy a tanulóknak milyen élményeik, tapasztalatuk lesz a mozgásról, a mozgás örömérôl. Vagyis arról, hogy jó-e a sport számukra vagy rossz, pontosabban egy adott sportág, mozgásforma képvisel-e számukra értéket vagy nem. Mert eredendően egyik mozgásforma sem jó vagy rossz, hanem van, akinek jó, és van olyan eset is, amikor valakinek rossz.

A lényeg a differenciálás: kinek és milyen körülmények között jó egy adott sportág, egy adott mozgásforma. Nem mindegy, hogy ezt a különbségtételt, az ehhez kapcsolódó döntést ki hozza meg: oktatáspolitikus vagy testnevelő tanár; mindez az érintett gyermekektől milyen távolságra történik; mennyire vonódnak bele a tanulók. David (2005) hívja fel a figyelmet arra, hogy az iskolai testnevelésre a demokratizálódás ellenére az úgynevezett szükségletalapú megközelítés a jellemző. Vagyis a felnőttek a gyermekek - az általuk fontosnak ítélt - szükségleteit meghatározva építették fel a tantárgy követelményeit, célértékeit. Davis szerint szemléletváltásra lenne szükség: nemzetközi egyeztetéssel megfogalmazott, hazánkban is elfogadott gyermeki jogok felől kellene közelíteni a kérdéshez. Nem a szükségletek, hanem a gyermekek legfőbb érdeke figyelembevétele és a testük felett való rendelkezés joga felől. Ebből a nézőpontból a mozgás örömét is könnyebb lenne beemelni a pedagógiai kánonba.

\section{Hivatkozott irodalom}

- Bauer B. (2002). Az ifjúság viszonya az értékek világához. In Szabó A., Bauer B. \& Laki L. (szerk.): Iffúság2000 Tanulmányok I. (pp. 202-219). Budapest, Nemzeti Ifjúságkutató Intézet.

- Beck, U. (2003). A kockázat-társadalom: út egy másik modernitásba. Budapest, Andorka Rudolf Társtudományi Társaság, Századvég.

- Bourdieu, P. (1996). A sport és a társadalmi osztályok. In Misovicz F. (szerk.): Sport és társadalom (pp.119-139). Budapest, BKE.

- Bodnár I. (2007). Mi, testnevelési tanárnők: egy szakma női kollektív identitásának kialakítása. Iskolakultúra, 17 (8-10), 60-69.

- Coakley, J. (2011). Youth Sports: What Countsas „Positive Development?” Journal of Sport and Social Issues, 35 (3), 306-324.

- Coakley, J. \& Pike, E. (2012). Sports in Society: Issues and Controversies. London: McGraw Hill.

- David, P. (2005). Human rights in youth sport. London, Routledge.

- De Bosscher, V., Shibli, S., van Bottenburg, M., De Knop, P. \& Truyens, J. (2010). Developing a method for comparing the elite sport systems and policies of nations: a mixed researchmethods approach. Journal of Sport Management, 24 (5), 567-600. 
- Donáth P. (2007). Adalékok Nagy László pályájához. Budapest, Trezor Kiadó.

- Éber M. (2008). Túl az élménytársadalmon? - avagy az élménytársadalom másfél évtizede. Szociológiai Szemle, (1), 78-105.

- Eichberg, H. (2009). Bodilydemocracy: Towards a philosophy of sport for all. Sport, Etics and Philosophy, 3 (3), 441-461.

- Freeman, P., Leslie, A., Leger, H. \&Williams, C. (2013). How important are values of significant others? In Whitehead, J., Telfer, H. \& Lambert, J. (eds.): Values in youth sport and physical education (pp. 178-190). London, Routledge.

- Inglehart, R. \& Baker, W. E. (2000). Modernization, culturalchange, and the persistence of traditional values. American Sociological Review, 65 (1), $19-51$.

- Kirk, D. (2011). Children learning in physical education: a historical overwiew. In Armour, K. (ed.): Sport pedagogy (pp. 24-38). Harlow, Pearson.

- Kovács K. \& Perényi Sz. (2014). A sportolás és egészség. Kapcsolatok a fiatalok fizikai, mentális és szociális jóllétének szubjektív szintjével. In Nagy Á. \& Székely L. (szerk.): Másodkézből. Magyar Ifjúság 2012 (pp. 245-262). Budapest, ISZT Alapítvány, Kutatópont.

- Lee, M., Whitehead, J. \& Balchin, N. (2013). Which sport values are most important to young people? In Whitehead, J., Telfer, H. \& Lambert, J. (eds.): Values in youth sport and physical education (pp. 49-65). London, Routledge.

- Perényi S. (2010a). The relation between sport participation and the value preferences of Hungarian youth. Sport in Society, 13 (6), 984-1000.

- Perényi S. (2010b). Value priorities in connection to sport participation. Physical Culture and Sport. Studies and Research, (48), 84-98.

- Perényi Sz. (2010c). Sportoló és nem sportoló fatalok életvitelhez kapcsolódó értékei. Doktori Disszertáció. Budapest, Semmelweis Egyetem, Testnevelési és Sporttudományi Kar.

- Perényi Sz. (2011). Sportolási szokások - Sportolási esélyek és változástrendek. In Bauer B. \& Szabó A. (szerk.): Arctalan(?) nemzedék? (pp. 159-184). Budapest, Nemzeti Család- és Szociálpolitikai Intézet.

- Perényi Sz. (2013). Alacsonyan stagnáló mozgástrend - A fizikai inaktivitás újratermelődése. In Székely L. (szerk.): Magyar Ifjúság 2012 Tanulmánykötet (pp. 229-249). Budapest, Kutatópont.

- Perényi S. \& Bodnár I. (2015). Sports Clubs in Hungary. In Breuer, C., Hoekman, R., Nagel, S. \& van der Werff, H. (eds.): Sport Clubs in Europe. A cross-national comparative Perspective (pp. 221-247). Basel, Springer International Publishing.

- Pringle, R. (2010). Finding pleasure in physical education: A critical examination of the edicative value of positive movement affects. Quest, (62), 119-134.

- Scheerder, J. \& Breedveld, K. (2004). Incomplete democratization and signs of individualization. An analysis of trends and differences in sports participation in the Low Countries. European Journal for Sport and Society, 1 (2), 115-134.

- Scheerder, J., Vandermeerschen, H., van Tuyckom, C., Hoekman, R., Breedveld, K. \& Vos, S. (2011). Understranding the game. Sport participation in Europe. Fackts, 
reflections, and recommendations. Leuven, Research Unit of Social Kinesiology \& Sport management, K. U.

- Schulze, G. (2000). Élménytársadalom. A jelenkor kultúrszociológiája. A mindennapi élet esztétizálódása (magyar fordításrészlet az 1. fejezetből). Szociológiai Figyelö, (1-2), 135-157.

- Schwartz, S. H., Bardi, A. \& Bianchi, G. (2000). Value adaptation to the imposition and collapse of communist regimes in East-Central Europe. In. Renshon, S. A. \& Duckitt J. (eds.): Political Psychology. Cultural and Crosscultural Foundations (pp. 217-237). London, Palgrave Macmillan.

- Skille, E. Å. (2005): Individuality or cultural reproduction? Adolescents'sport participation in Norway: Alternative versus conventional sports. International Review for the Sociology of Sport, 40 (3), 307-320. 


\title{
URbinNÉ BorbÉLy SZILVIA
}

\section{A testnevelők és a testnevelés tantárgy presztízse a megváltozott testkulturális környezetben}

\begin{abstract}
Absztrakt
2002-ben a lakosság egyharmada vélte úgy, hogy nagy szerepe van a pedagógusoknak abban, hogy Magyarország sorsa hogyan alakul a következő évtizedekben (Cs. Czahesz \& Radó 2003). A pedagógusok helyzetének általános megítélése mellett, mely magába foglalja a különböző pedagógusszakmai csoportok presztízsének a vizsgálatát, a testnevelő tanári szakma megítélését kiemelten kezeljük, amit a 2012-ben bevezetett mindennapos testnevelés hatásának vizsgálata is indokol. A foglalkozások, szakmák hierarchiába rendezésével egyfajta szimbolikus hatalom képét kaphatjuk meg, mely a foglalkozások „szimbolikus” vagy tényleges hatalmi helyzetét is megmutatja. A presztízshierarchia csak olyan helyzetekben értelmezhető, ahol a résztvevők például tisztelik a felettük állókat, keresik, sokra tartják a velük való kapcsolatot. Azok a módozatok, melyek kialakulnak a presztízs szimbolikus jellege folytán a résztvevők számára kedvezőek lehetnek, befolyásolhatják, módot adhatnak stílusok kialakítására, s mindezek már konvertálhatóak s felhasználhatóak a presztízs további növelésére (Léderer 1977; Maár 2002).

Kutatásunk célja, hogy megvizsgáljuk, milyen ebben a megváltozott helyzetben a pedagógusok és a testnevelés tantárgy presztízse, illetve hogy mutatkozik-e egyetértés a mindennapos testnevelés bevezetésének elfogadásával kapcsolatban a különböző szakok esetében. Kutatásunkat 2016 tavaszán az Észak-Alföld régió intézményeiben végeztük saját készítésű kérdőív segítségével $(\mathrm{N}=230)$ a pedagógusok presztízsével, illetve a tantárgyak és a mindennapos testnevelés társadalmi elfogadásával kapcsolatosan.

Eredményeinkben a foglalkozások társadalmi elfogadásánál a szakirodalomban is megjelenő szakmák emelkednek ki, azonban az oktatási szintek hierarchiája (óvodapedagógus, alapfokú, középfokú, felsőfokú oktatás) itt nem mutatható ki. Megállapítható továbbá, hogy a pedagógusok alulértékelik magukat a tanári szakma társadalmi megítélésekor, továbbá a testnevelés tantárgy elismertsége és a mindennapos testnevelés elfogadásának mértéke különbségeket mutat a testnevelést tanító és nem tanítók között.
\end{abstract}

\section{Bevezetés}

Az iskolai munkában a testnevelők szerepét többen igazolják. A 2010-es magyarországi pedagógusvizsgálatok eredményei kapcsán Lannert (2010) is leírja tanulmányában, hogy a pedagógusok szerepe egy tudásalapú társadalomban egyre nagyobb, 
azonban a gyenge presztízsük miatt motiválatlanok. A közoktatás-fejlesztési beavatkozások sikerességét és eredményességét, mint például a 2012 szeptemberében bevezetett mindennapos testnevelést vagy a pedagóguséletpálya-modellt, jelentősen meghatározzák az azt jellemző implementációs folyamatok.

Maár (2002) kutatási eredményei azt mutatják, hogy minél alacsonyabb fokon tanít egy pedagógus, annál alacsonyabb a megbecsültsége, és a pedagógusok saját foglalkozásukat a legalacsonyabb presztízsűnek értékelik. Szabó (1998) kutatásában is azt erősíti meg, hogy a pedagógusok nem érzik, hogy a társadalom anyagi és társadalmi megbecsülése megfelelő lenne. A presztízsvizsgálat esetében a testneveló tanári szakma megítélése lesz a cél a 2012-ben bevezetett mindennapos testnevelést bevezető időszakot követően. Volkamer (1993) azt állapítja meg, hogy a sport pedagógiai célokkal való kapcsolata nem elutasítandó, de a megvalósulása, eredményessége a pedagóguson múlik, és a legfontosabb lehetőséget erre az iskolai sport területe adja. Mindezek mellett úgy tủnik, hogy a pedagóguspálya vonzereje csökkenő tendenciát mutat a fejlett gazdasági mutatókkal rendelkező országokban (Imre \& Nagy 2003), a tanári presztízs egybehangzóan gyenge szinten van (Nagy 2001), a testnevelők megítélése pedig közepes.

A pedagógusok között a tanári szakok hierarchiába rendezésével egyfajta szimbolikus hatalom képét kaphatjuk meg. Ez az egyénnek arra való képességét jelenti, hogy céljainak elérése érdekében értékeket aknázzon ki. A hétköznapi szóhasználatban a foglalkozáspresztízs általában anyagi és erkölcsi (társadalmi) megbecsülést jelent. Azok a módozatok, melyek kialakulnak a presztízs szimbolikus jellege folytán, a résztvevők számára kedvezőek lehetnek, befolyásolhatják, módot adhatnak stílusok kialakítására, s mindezek már konvertálhatóak s felhasználhatóak a presztízs további növelésére (Maár 2002).

Kutatásunkban a 2012 szeptemberétól felmenő rendszerben bevezetett mindennapos testnevelés, valamint a pedagóguséletpálya-modell (és az ezzel járó bérnövekedés) utáni állapotot vizsgáljuk az intézmények mikrokörnyezetében, vagyis azt az implementációs folyamatot, amelyben a pedagógusok dolgoznak.

\section{Elméleti háttér}

\section{Pedagóguskutatások}

A sport politikai megjelenésében érvényesül az az oktatáspolitikai meghatározás, mely szerint a sport fogalma az oktatást és azok rendszereinek érdekérvényesítését jelenti. Másrészt a szakpolitikák oktatással kapcsolatos fejlesztési elképzeléseként is értelmezhető, amelynél koronként és társadalmanként különbségek figyelhetőek meg. A sport kiemelkedő szerepe és folyamatos jelenléte a politikában és oktatásban sem hozta meg az elvárt eredményeket. Minden korszakban újabb felismerésként tárultak elénk a súlyos hiányosságok, amelyekre koncepciók, stratégiák születtek, azonban a finanszírozás elmaradása miatt ezek megvalósítása nem következett be (Polónyi 2008). 
Az oktatáskutatások szinte minden országban a legkevésbé támogatott kutatások körébe tartoznak. Az oktatáskutatások terén kiemelt figyelmet kellene szentelni az ok-okozati meghatározásokra törekedő kutatásokra, amelyekben a valós élet szituációját modellezik (Gáti 2009). Az oktatás eredményességének fontosságát, a gazdaságra gyakorolt hatását több kutatási eredmény is igazolja. Ezért minden kormányzat érdekelt abban, hogy az oktatás folyamatáról, eredményességéről kutatási eredményeket vizsgáljon és csatoljon vissza a hatékonyság növelése érdekében (Lannert 2010).

A tanárok presztízsének vizsgálatával hazánkban is már több kutató foglalkozott. Fónai és Dusa (2014) is kimutatták tanulmányukban, hogy a pedagógusok általánosságban vett státusza a jövedelmi pozíció és a társadalmi presztízs területén is romlik. A pedagógusok ellentmondásos társadalmi helyzetét a professzióhoz szükséges tudás és a megszerezhető jövedelem, valamint az elérhető szakmai siker és a presztízs között fellépő inkongruencia is jellemzi. Ingersoll (2001) eredményei alapján az is kimondható, hogy a probléma egyik legfőbb oka az alacsony pedagógusbér mellett a helyi és központi vezetés-irányítás problémái, a tanulók alacsony motivációja, a fegyelmezési gondok minőségileg és mennyiségileg is növekvő jellege. Polónyi (2015) a pedagógusbérek vizsgálatával foglalkozó tanulmányát azzal a kijelentéssel kezdi, hogy a gazdasági növekedés és az oktatás minősége között kapcsolat fedezhető fel. Vagyis egy ország oktatási rendszerének teljesítménye hatással van annak gazdasági eredményeire. Az oktatási rendszer minőségét meghatározó eleme közül az egyetlen teljes bizonyossággal szereplőnek a pedagógusok szerepét emeli ki és azt, hogy a munkabérek összefüggésben állnak egy-egy foglalkozás presztízsével.

Történelmi visszatekintés során is megállapítható, hogy az alapfokú oktatásban tanítók bére mindig a szellemi foglalkozások utolsói között helyezkedett el. Az elmúlt 30 évben is megfigyelhető, hogy más foglalkozásokhoz viszonyítva a pedagógusok béraránya romlik (2002-ben volt egy kisebb javulás, de a későbbiekben a keresetromlás folytatódott). Mivel a keresetarányok együtt mozognak a szakma presztízsével, ezért a pedagóguspresztízs csökkenése ennek függvényében deklarálható volt. Mindez viszszahat az oktatás minőségére is. Galasi (2004) is megállapította, hogy a pedagógusok körében a bérrel való ösztönzés gyengesége miatt a munkaviszony stabilitása erős szelekciós és ösztönzési tényezőként működik. Verroszta (2015) a tanári pályaelhagyás szaktárgyi mintázatát vizsgálta, illetve azt, hogy ezek munkaerőpiaci hozadéka különböző-e. A testnevelés és egészségfejlesztés területén végzettek jövedelme mindkét esetben átlag feletti értéket mutat. Megállapítható, hogy megéri elhagyni a pályát, hiszen a presztízs, a jövedelem, a tárgyi és személyi feltételek is jobbak a pályát elhagyók számára az oktatás területén kívüli szakmákban. Az okok esetében a szakterületek közti elismerésben lévő különbségek is megfigyelhetők. A testnevelőknél a jövedelem és a juttatások, valamint a munkahelyi körülmények elégedettségi értéke mutatkozik meg.

Nagy (1998) a pedagógusok presztízsének kutatásában jellegzetes sajátosságokról ír. A különböző iskolafokozatokon tanítók közti hierarchia és a tudással, valamint hatalommal való nagyobb korreláció jelenti a presztízsrangsor elejét. Mindeközben 
az anyagi és társadalmi megbecsülés közti kapcsolat terén azt is kimutatta, hogy a közvélemény a tanárok anyagi megbecsülését alacsonyra értékeli, de a társadalmi megbecsülést már magasabbra tartják. A legnagyobb különbséget a két arányszám között a pedagógusszakma esetében mutatták ki. Győri (2004) kutatása során a pedagógusokat, a szülőket és a diákokat kérdezte a tantárgyak presztízsével kapcsolatban. A legmagasabb átlagot az angol, míg a legalacsonyabbat az ének-zene mutatta.

\section{A testnevelök presztizse és a testnevelés tantárgy megitélése}

A 90-es évek előttti kutatások már azt támasztják alá, hogy az iskolai hatások közül a pedagógus munkájának minősége nagyon fontos (Andorka \& Simkus 1983). Trencsényi már 1988-ban azt állítja a testnevelőkról, hogy fontos intézményi szerephordozók annak ellenére, hogy - Elbertné (1987) szerint - a tantestületen belüli presztízsüket rosszabbnak ítélik, mint az kívánatos lenne.

A testnevelóknek az a feladata, hogy hatást gyakoroljanak a gyerekek személyiségfejlődésére a sporton keresztül, mellyel befolyásolni lehet teljes viselkedésrepertoárjukat. Feladatuk továbbá a gátlások alatt lévő adottságok felszínre juttatása, a sikerek és kudarcélmények feldolgozásának segítése (Csepela 2000). Kocsis (2000) kutatásában a diákok a legkedveltebb tantárgyak közé sorolják a testnevelésórát. A testnevelés tantárgy legfontosabb meghatározója a testnevelő tanárok érték-érdek képviselete a helyi tantervben a tantárggyal szemben, hiszen a pedagógusoknak képessé kell válniuk szakterületük érdekeik képviseletére, amely által az iskolai dokumentumokban is megjelenést kap a sport kiemelt szerepe (Rétsági \& H. Ekler 2004). Bognár és Kovács (2007) empirikus tanulmánya arról számol be, hogy a felső tagozatos tanulók túlnyomó többsége kifejezetten fontosnak véli a testnevelés tantárgyat az iskolában. Ugyanakkor érdekes ennél a tanulmánynál megemlítenünk, hogy a testnevelő nők diákjai szignifikánsan többen említették, hogy fontos a testnevelésóra, mint a férfi testnevelők diákjai. Bognár és mtsai. (2008) is arra a megállapításra jutottak, hogy a hiedelmekkel és kutatási eredményekkel ellentétben a testnevelők presztízse jónak tekinthető. A felmérésben részt vevő 564 testnevelő nagy része is úgy gondolja, hogy elismerik munkájukat az iskola szereplői. Korábbi kutatásunkban a felnőtt lakosság (szülők) körében végeztünk országos reprezentatív kutatást, hogy ők maguk mennyire tartják fontosnak a mindennapos testnevelés bevezetését, milyen szerepet tulajdonítanak a testnevelőnek gyermekük sportolási gyakoriságának alakulásában, illetve mennyire tartják fontosnak, hogy gyermekeik kedveljék a testnevelésórákat (Borbély 2014). A mindennapos testnevelés bevezetésének szükségességével a megkérdezettek 70\%-a ért egyet, vagyis a felnőtt lakosság (potenciálisan a szülők) is szükségét érezte a mindennapos testnevelés bevezetésének. A szülők a testnevelôk hatását gyermekük sportolási gyakoriságára és a testnevelés tantárgy kedveltségére $(73,5 \%)$ egyaránt fontosnak itélték.

\section{A mindennapos testnevelés}

Tanulmányunk vizsgálata arra az iskolai közegre fókuszál, amelyben a mindennapos testnevelés bevezetésével az iskolai testkultúrában változások következtek be. 
Hiszen a testkultúra azon értékek összességét jelenti, amelyek az emberiség fejlődése folyamán a mozgásmúveltség, a testi képességek, a szervezet megedzése és az egészség megszilárdítása révén jönnek létre. Ebbe a fogalmi körbe tartozik a test ápolása, a testnevelés és sport, továbbá az ezekkel kapcsolatos szervezetek és intézmények, illetve a szakemberek képzése, a testneveléssel és sporttal kapcsolatos orvosi eljárások, a felszerelések készítése, valamint a mindezekkel összefüggő elméleti munkák, kutatások és eredmények (Bély \& Kálmánchey 1967). Takács (2009) szerint is a testkultúra egy olyan gyújtőfogalom, amelybe beletartozik a testmozgáshoz kapcsolható elméleti tudás, anyagi eszköz, illetve olyan fogalmak, mint a testnevelés, sport, gimnasztika, testgyakorlatozás vagy éppen a rekreáció.

A fogalom a 2012-es Nemzeti alaptanterv testnevelés és sport múveltségterületének megváltozott céljai között való megjelenése jelenti azt a megváltozott testkulturális környezetet, amely az oktatási intézményekben a mindennapos testnevelés bevezetése utáni időszakban van jelen. Ugyanis a mindennapos testnevelés új kihívást hozott a testnevelő tanárok számára. A megnövekedett óraszámok tartalmas, élményekben gazdag, a tanulók érdeklődésének megfelelő újszerủ testgyakorlati, illetve sportágakkal történő megvalósítása a kívánatos cél. Ehhez a kerettantervek szakmailag alaposan összeállított, színes és sok újszerú tartalommal járulnak hozzá, a választhatóság biztosításával. Módszertani javaslataik a tanulóközpontúság elveit veszik figyelembe, a differenciált oktatás a fizikai aktivitás iránti pozitív hozzáállást erősíti (Rétsági 2014).

A tantervi változások szükségességét nemcsak a társadalompolitikai és egyéb tényezők határozzák meg, hanem az iskolai eredményességi kutatások tapasztalatai is. A Nemzeti alaptantervet az 1989/90-es tanévben vezették be. A törvény 41. paragrafusa kötelező jelleggel írta elő a tanulók fizikai állapotának mérését, amellyel a testnevelők 45\%-a teljes mértékben, míg 47\%-uk részben értett egyet. A törvény 52. paragrafusa (9) írja elő az iskola tanulói és az intézmény számára a mindennapos testnevelés bevezetéséhez szükséges feltételeket, azok megteremtését. A kutatási eredmények között megjelenik, hogy a testnevelők véleménye az, hogy a mindennapos testnevelés szükséges (91\%). Ezzel szemben 1/3-uk azt nyilatkozta, hogy a jelenlegi infrastrukturális feltételekkel ez nem valósítható meg.

A 2006-os törvénymódosítás kiemelten kezeli a szakrendszerủ és nem szakrendszerú oktatást az 5. és 6. évfolyamon, valamint a mindennapos testnevelést. A testnevelő tanárok 77\%-a nem ért azzal egyet, hogy tanítói végzettséggel a 6. osztályban is taníthassanak testnevelést a nem testnevelés szakos pedagógusok. Ezzel egy időben a testnevelőket kötelezték arra, hogy amennyiben 1-4. osztályig szeretnének testnevelést tanítani, vegyenek rész továbbképzésen. A tanárok $2 / 3$-a elutasítja ezt a döntést. „Ez a rendelkezés nagyban hozzájárult a testnevelés tantárgy iskolai elismertségének gyengüléséhez is!" (Elbert 2010: 62)

A 2012-ben elfogadott Nemzeti alaptanterv az iskolai testnevelést már az egészségfejlesztés megkülönböztetett részeként kezeli, és a mindennapos testnevelés bevezetését írja elő a 2012/13-as tanévtól az 1., 5. és 9. évfolyamon, amelyet a heti öt testnevelésóra keretében kell megvalósítani. A mindennapos testnevelés bevezetése jelentős 
fordulópont a testnevelés oktatásában, amelynek bevezetéséhez az előző évtizedekben történő szakmai előkészítések, kutatási eredmények is hozzájárultak. A diákoknak a sport melletti elköteleződésében a rendszeres testmozgás mellett a testnevelő tanárok iránti szeretet is meghatározó szerepet tölt be, ami a tanulók iskolai teljesítményére is pozitív hatást gyakorol (Mikulán 2013).

\section{Empirikus kutatás}

Kutatásunkat 2016 tavaszán az Észak-Alföld régió intézményeiben végeztük saját készítésú online kérdôív segítségével $(\mathrm{N}=230)$. A vizsgált régióban 4648 fő képezi a teljes populációt. A mintavétel során többlépcsős, rétegzett mintavételt alkalmaztunk, ennek utolsó lépcsőjében a településen belül véletlen mintavétellel választottuk ki az iskolákat, s ezeken belül a pedagógusokat. Így a minta megyére és településtípusra vonatkozóan reprezentatívnak tekinthető. A három megye 15 intézményéből 230 pedagógus válaszait vizsgáltuk. Az adatok feldolgozásakor a gyakorisági mutatókon túl összefüggés-vizsgálatokra is sor került. A pedagógusoknak szóló kérdőív a személyes kérdéseken kívül az általános iskolai tantárgyak kedveltségére, a mindennapos testnevelés bevezetésével kapcsolatos állításokra, a tantárgyak és foglalkozások társadalmi megbecsülésére, illetve a mindennapos testnevelés céljainak megvalósulására kérdezett rá. A minta nemek szerinti megoszlásánál (nő = 74,8\%, ffi = 25,2\%) hasonlóság mutatkozik a központi információs adatbázis eredményeivel. Ezen belül vizsgáltuk a testnevelés és nem testnevelés szakosok megoszlását. Megállapítható, hogy a minta alanyainál a férfiak 63,8\%-a testnevelés szakos, míg ez a nők esetében csak 22,6\% (1. ábra). Ez az eredmény is illeszkedik a központi statisztikai adatok eredményeihez.

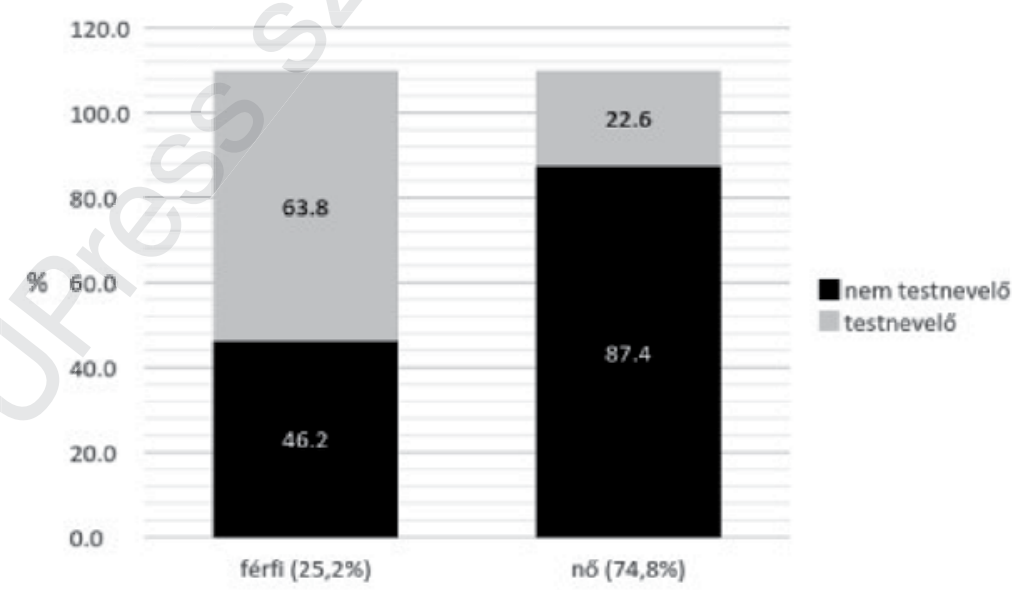

1. ábra. A női és férfi testnevelők és nem testnevelők aránya ( $N=230)$. Forrás: saját kutatás 
Elsődleges kutatási kérdésünk az volt, hogy a mindennapos testnevelés bevezetését követően a mikroszint vizsgálata esetében megnézzük, hogy a pedagógusok a mindennapos testnevelés implementációs folyamatában milyen befogadókészséggel rendelkeznek, hogyan ítélik meg ennek szerepét, illetve szakmájuk és tantárgyuk társadalmi megítélését. Vagyis jelen tanulmány azt vizsgálja, hogy a testnevelő tanárok és a tantárgy presztízse mennyiben felel meg a mindennapos testnevelés implementációs elvárásainak.

Az oktatási rendszerben történt egyik legfontosabb változások bevezetése - életpályamodell bevezetése, az ezzel járó keresetnövekedés, a mindennapos testnevelés bevezetése - utáni vélemények vizsgálata esetében a bérek növelésével együtt járó presztízsnövekedést várjuk, amiben az iskolafokok közti különbségek is kimutathatóak lesznek (Polónyi 2015; Maár 2002). Emellett a mindennapos testnevelés bevezetésével való egyetértést, illetve a testnevelés tantárgy társadalmi megítélését is feltételezzük, hiszen a testnevelők intézményi szerephordozók az egészségtudatos magatartás, életmód, sportolási gyakoriság és a tanulmányi eredményesség tekintetében (Papacharisis 2003; Rétsági \& Ekler 2004; Fintor 2013; Kovács 2015a; 2015b).

\section{Hipotéziseink}

H1 - A minta alanyainál a mindennapos testnevelés bevezetésével való egyetértésben szakonkénti eltérést nem tapasztalunk.

H2 - A minta alanyai a testnevelés tantárgyat a tantárgyi megbecsülések összátlaga fölött értékelik, szakonkénti különbségek kimutathatók lesznek.

H3 - A minta alanyainál a foglalkozások társadalmi megbecsülése esetén a tanári foglalkozások átlag alatti értéket fognak mutatni.

\section{Eredmények}

Első hipotézisünk vizsgálatánál a mindennapos testnevelés bevezetésével való egyetértést elemeztük (1. táblázat). Megállapítható, hogy a megkérdezettek 55,9\%-a egyetért a mindennapos testnevelés bevezetésének szükségességével, és a testnevelő, illetve nem testnevelő szakos pedagógusok esetében szignifikáns eltérés $(p=0,000)$ is kimutatható. A nem testnevelés szakos pedagógusok esetében a teljes elfogadás értéke 17,8\% azonban igen alacsonynak mondható, továbbá az egyetértés és egyet nem értés aránya is közel azonos (49,3\%-49,4\%). A testnevelők esetében a teljes elfogadás értéke magas eredményt mutat (59,5\%), és az egyetértés is kiemelkedő értékű 76,1\%. 
1. táblázat. A mindennapos testnevelés bevezetésével való egyetértés $(\mathrm{N}=228)$

\begin{tabular}{|l|c|c|}
\hline & Nem testnevelo (81,8\%) & Testnevelő (18,2\%) \\
\hline Egyáltalán nem $(17,7 \%)$ & $20,8 \%$ & $9,5 \%$ \\
\hline Inkább nem $(23,4 \%)$ & $28,6 \%$ & $11,9 \%$ \\
\hline Inkább igen $(28,6 \%)$ & $31,5 \%$ & $16,6 \%$ \\
\hline Teljes mértékben $(27,3 \%)$ & $17,8 \%$ & $59,5 \%$ \\
\hline
\end{tabular}

Forrás: saját kutatás

Hipotézisünk, mely szerint a mindennapos testnevelés bevezetésével való teljes mértékű egyetértésben szakonkénti eltérések nem lesznek kimutathatóak, nem igazolódott be, hiszen a nem testnevelők esetében jóval alacsonyabb a teljes elfogadás. A bevezetésének szükségességét a minta alanyainak 55,9\%-a ismerte el, ami elmarad más előzetes eredmények értékétől.

Következő hipotézisünk esetében a tantárgyak társadalmi megítélésére voltunk kíváncsiak (2. táblázat). A válaszadóknak egy 10-es skálán kellett értékelniük az adott tantárgyakat, ahol az 1-es a legkevésbé és a 10-es a leginkább megbecsült kategóriát jelentette.

A tantárgyak összátlaga $(5,32)$ feletti értékeket az angol $(7,16)$, a matematika $(6,44)$, a magyar (6,33), a történelem $(5,78)$ (tehát érettségi tárgyak), valamint az informatika $(6,64)$ esetében találtunk. Legalacsonyabb tantárgyi státusza az ének-zenének $(3,55)$ és a technikának $(3,78)$ van, de a kémia $(4,72)$ és fizika $(4,74)$ tantárgyak értékei is alulmaradnak a tantárgyak összátlagértékeinél. A legmagasabb és legalacsonyabb presztízsű tantárgy esetében egyezést tapasztalunk Győri 2004-es kutatási eredményeivel. A testnevelés tantárgy $(4,91)$ megítélése az átlag alatti értéket mutatja.

2. táblázat. A tantárgyak társadalmi megítélésének átlagai $(\mathrm{N}=230)$

\begin{tabular}{|l|c|}
\hline TANTÁRGYAK & ÁTLAG \\
\hline Angol & 7,16 \\
\hline Informatika & 6,64 \\
\hline Matematika & 6,44 \\
\hline Magyar & 6,33 \\
\hline Történelem & 5,78 \\
\hline ÁTLAG & $\mathbf{5 , 3 2}$ \\
\hline Biológia & 4,94 \\
\hline Testnevelés & 4,91 \\
\hline Földrajz & 4,81 \\
\hline Fizika & 4,74 \\
\hline Kémia & 4,72 \\
\hline Technika & 3,78 \\
\hline Ének-zene & 3,55 \\
\hline
\end{tabular}


Megvizsgáltuk, hogy a válaszadók szakos eltérései megmutatkoznak-e az eredményekben. Megfigyelhető, hogy saját szakját mindenki előrébb helyezi, mint azt az összátlagok mutatják. A testnevelés és nem testnevelést tanítók között azonban szignifikáns különbséget egyik tantárgy megítélésében sem tapasztaltunk. A mindennapos testnevelés megítélésével kapcsolatos egyetértések esetében sem találtunk a testnevelés tantárgy társadalmi megítélésében szignifikáns különbséget a válaszadóknál.

Második hipotézisünk nem igazolódott be, hiszen a testnevelés tantárgy megbecsülése elmarad a tantárgyi átlagtól, és megítélésében szakonkénti eltérések sem voltak kimutathatóak. Azonban a pedagógusok saját szakjukat, a szakirodalomban is olvasható módon, felülértékelik más szakokkal szemben.

A harmadik hipotézis vizsgálatakor a foglalkozások társadalmi elismertségét néztük meg (3. táblázat), a válaszadóknak egy 10-es skálán kellett értékelniük az adott foglalkozásokat, ahol az 1-es a legkevésbé és a 10-es a leginkább megbecsült kategóriát jelentette.

3. táblázat. A foglalkozások társadalmi megbecsülésének átlaga $(\mathrm{N}=230)$

\begin{tabular}{|l|c|}
\hline FOGLALKOZÁS & ÁTLAG \\
\hline Orvos & 7,56 \\
\hline Ügyvéd & 7,50 \\
\hline Jogász & 7,38 \\
\hline Közgazdász & 7,28 \\
\hline Mérnök & 7,22 \\
\hline Informatikus & 6,72 \\
\hline Gyógyszerész & 6,61 \\
\hline Egyetemi oktató & 6,49 \\
\hline ÁTLAG & $\mathbf{5 , 9 6}$ \\
\hline Lelkész & 5,61 \\
\hline Újságíró & 5,56 \\
\hline Sportedzö & 5,14 \\
\hline Középiskolai tanár & 5,04 \\
\hline Óvodapedagógus & 4,34 \\
\hline Általános iskolai tanár & 4,26 \\
\hline Tanító & 4,25 \\
\hline Könyvtáros & 3,86 \\
\hline
\end{tabular}

Forrás: saját kutatás

A pedagógusok presztízsét (az egyetemi oktatón kívül) az újságíró, a gyógyszerész és a lelkész mögé sorolják. Az, hogy eltéréseket nem tapasztaltunk sem szak, sem nem, sem pedig státusz esetében a minta esetében, a teljes egyetértést mutatja a presztízs meghatározásánál. A leginkább elkeserítő eredmény (a pedagógusok viszonylatában), hogy amíg egy orvos, jogász, mérnök átlagértéke 7,2 fölött található, addig a tanárok átlagai csak 5,04 és 4,25 között mozognak. 
Az iskolafok közötti különbségek vizsgálatánál nem mutatható ki lineáris összefüggés, hiszen az óvodapedagógus megelőzi a tanító és az általános iskolai tanárt is, azonban a pedagógusok alulértékelése egyértelmúen kimutatható, ami egyetértést mutat Nagy (2012) eredményeivel. Kijelenthetjük, hogy Maár (2002) eredményeivel összhang mutatható ki a 2012-es mindennapos testnevelés bevezetését követő időszakban is a pedagógusok társadalmi megitélésével kapcsolatban, presztízsük alacsony.

\section{Összegzés}

Minden országban a pedagógusok, testnevelók kulcsszerepet játszanak az állam által meghatározott testnevelés-oktatás általi nevelési és oktatási célok megvalósításában. Ezek között a fizikai aktivitás növelése, a sportágak megismertetése és a diákok értékelése, illetve egészségtudatosságra nevelése szerepel. A pedagógusnak nemcsak az a feladata, hogy megszervezze és megtartsa a testnevelés-foglalkozásokat, hanem a szükséges készségeket is ki kell alakítania az egészséges életmód elősegítése, a sport iránti motiváció növelése és a diákok különböző sportágakba való bevonása által. Ehhez szükséges megteremteni számukra a folyamatos szakmai innovációs lehetőségeket és azt a környezetet, amelyben motiváltan, presztízsüket elfogadva dolgozhatnak.

A 2012-ben történt oktatáspolitikai beavatkozások (pedagóguséletpálya-modell és a mindennapos testnevelés bevezetése) utáni helyzetben vizsgáltuk a pedagógusok, testnevelők és a tantárgyak társadalmi megítélését, illetve a mindennapos testnevelés bevezetésével kapcsolatos véleményeket.

Megállapítható, hogy a pedagógusok presztízse a vizsgált foglalkozások tekintetében még mindig alacsony értéket mutat, vagyis társadalmi státuszuk nem emelkedett, és az egyes hierarchia szerinti értékek is felcserélődtek. A vizsgált háttérváltozók (szak, életkor, nem) esetében sem találtunk különbségeket az értékek vizsgálatakor, ami azt igazolja, hogy a pedagógustársadalom egybehangzóan vélekedik szakmájuk társadalmi megítéléséről. A testnevelés tantárgy megbecsülése a tantárgyi átlagok alatti értéket mutat, ennél a testnevelés szakos pedagógusok esetében találunk eltérést. Azonban megállapítható, hogy minden pedagógus esetében megjelenik, hogy a saját szakjukat felülértékelik. A mindennapos testnevelés bevezetésével a megkérdezettek 55,9\%-a értett egyet, és a nem testnevelés szakos pedagógusok esetében az előzetes kutatatási eredményekhez képest alacsonyabb a teljes elfogadás értéke (17,8\%).

Eredményeink között figyelmet érdemel az az ellentmondás, ami a tantárgyi presztízs és a tárgyat tanító tanárok presztízse között érvényesül - ez azt mutatja, hogy maguk a tanárok is hamarabb érzékelik egyes tárgyak megítélésének a pozitív változásait, mint a változások hatását a saját helyzetükre. 


\section{Hivatkozott irodalom}

- Andorka R. \& Simkus A. (1983). Az iskolai végzettség és a szülói család társadalmi helyzete. Statisztikai Szemle, 61 (6), 592-611.

- Bély M. \& Kálmánchey Z. (1967). Testnevelés-elmélet. Budapest, Tankönyvkiadó.

- Bognár J., Istvánfi Cs., Kovács T. L. \& Antal Zs. (2008). Testnevelő tanárok presztízse: pályaválasztástól a pályaelhagyásig a nemek mentén. Kalokagathia (1), 48-59.

- Bognár J. \& Kovács T. L. (2007). Értékelés a testnevelés órán. Iskolakultúra, (1), 88-94.

- Borbély Sz. (2014). As parents see physical education (PE) from a representative survey's point of view. In Karlovitz J. T. (szerk.): Mozgás, környezet, egészség (pp. 9-55). Komarno, International Research Institute s.r.o.

- Cs. Czahesz E. \& Radó P. (2003). Oktatási egyenlőtlenségek és speciális igények. In Halász G. \& Lannert J. (szerk.): Jelentés a magyar közoktatásról 2003. Budapest, OKI.

- Csepela Y. (2000). „Örömtestnevelés?” - Gondolatok a testnevelésról, a sportról a 21. század küszöbén. Új pedagógiai Szemle, 2000. október, 83-89.

- Elbert G. (2010). Testnevelés és európai kulcskompetenciák a közoktatásban. $M a-$ gyar Sporttudományi Szemle, 41 (11), 10-13.

- Elbertné Sz. (1987). A testnevelő tanár szerepének néhány fő́bb sajátossága az iskolai nevelőtestületben. A Testnevelési Fóiskola közleményei, 1987/3. melléklet 27.

- Fónai M. \& Dusa Á. (2014). A tanárok presztízsének és társadalmi státuszának változásai a kilencvenes és a kétezres években. Iskolakultúra, (6), 41-48.

- Galasi P. (2004). Valóban leértékelödtek a felsófokú diplomák? Forrás: 1120"http:// www.econ.core.hu/doc/bwp/bwp/bwp0403.pdf. Utolsó letöltés: 2015.11. 20.

- Fintor G. (2013). Correlations of Sport Levels and Popularity of Sport Programmes among Elementary School Students. Hungarian Educational Research Journal, 3 (3). Forrás: http://herj.lib.unideb.hu/index.php?oldal=cikkadatok\&folyoirat_szam= 3/2013\&cikk_id=576\&. Utolsó letöltés: 2016.06.08.

- Gáti A. (2009). Nemzetközi tapasztalatok feltárása az oktatási ágazat $K+F+I$ és tudásmenedzsment rendszerek területén. Forrás: www.tarki-tudok.hu/file/tanulmanyok/ nemzetkozi_tanulmany.pdf. Utolsó letöltés: 2015. 05. 12.

- Győri A. (2004). A középiskolai tantárgyi obszerváció tanulságai. Forrás: http://ofi. hu/tantargyak-presztizse-pedagogusok-szerint. Utolsó letöltés: 2015.11. 25.

- Imre N. \& Nagy M. (2003). Pedagógusok. In Halász G. \& Lannert J. (szerk.): Jelentés a magyar közoktatásról 2003 (pp. 273-307). Budapest, OKI.

- Ingersoll R. (2001). Teacher Turnover and Teacher Shortages. An Organizational Analysis. American Educational Research Journal Fall, 38 (3), 499-534.

- Kocsis M. (2000). Egy Baranya megyei iskolai tudásmérés néhány vizsgálati területérôl. Iskolakultúra, (8), 3-13.

- Kovács K. (2015a). A sportolás mint támogató faktor a felsőoktatásban. Oktatáskutatók könyvtára 2. Debrecen, CHERD-H. 
- Kovács K. (2015b). A sportolási szokások és a tanulmányi eredményesség egy határmenti régió hallgatóinak körében. Educatio, (2), 130-138.

- Lannert J.(2010). Pedagógus 2010 kutatás - Nemzetközi kutatások a pedagógus munkaterhelés témában. Forrás: http://www.t-tudok.hu/file/tanulmanyok/v_nemzetkozi_ lj.pdf. Utolsó letöltés: 2015. 02.12.

- Léderer P. (1977). Foglalkozások presztízse. Budapest, Gondolat Kiadó.

- Maár T. (2002). Presztizsvizsgálat. Forrás: http://epa.oszk.hu/00000/00031/00003/ pdf/actapaed_EPA00031_2002_03_001-007.pdf. Utolsó letöltés: 2015.11. 22.

- Mikulán R. (2013). Az iskolai testnevelés szerepe és jelentősége az egészségfejlesztésben. Új Pedagógiai Szemle, 63 (7-8), 48-69.

- Nagy M. (2001). Tanárbérek régen és ma, nálunk és külföldön. In Papp J. (szerk.): A tanári pálya (pp. 82-86). Debrecen, Kossuth Egyetemi Kiadó, Debreceni Egyetem.

- Nagy M. (1998.). Tanári pálya és életkörülmények. Budapest, OKKER.

- Nagy P. (2012). Tantárgyak és társadalom. Educatio, (4), 503-512.

- Papacharisis, V. \& Goudas, M. (2003). Perceptions about exercise and intrinsic motivation of students attending a health-relatedphysical education program. Perceptual and Motor Skills, (97), 689-696.

- Polónyi I.(2008). Oktatás, oktatáspolitika, oktatásgazdaság. Forrás: http://www.academia. edu/9989063/Pol\%C3\%B3nyi_I_Oktat\%C3\%A1s_oktat\%C3\%A1spolitika_ oktat\%C3\%A1sgazdas\%C3\%A1g. Utolsó letöltés: 2015. 08. 18.

- Polónyi I. (2015). Pedagógusbérek - mindig lent? Educatio, (1), 30-46.

- Rétsági E. (2014). Mindennapos testnevelés az iskolában. Élet és Tudomány, 69(37), 1166-1167.

- Rétsági E. \& H. Ekler J. (2004). Az iskolai testnevelés és sport értékreprezentációja a helyi tervezés szintjén. Kalokagathia, (1-2), 101-108.

- Szabó I. (1998). Tanárok szakma- és szerepfelfogása a kilencvenes években. In Nagy M. (szerk.): Tanári pálya és életkörülmények: 1996-97 (pp. 145-176). Budapest, OKKER.

- Takács F. (1989): Az életmód és a testkultúra néhány szociológiai megközelítése. Testnevelés és Sporttudomány, (1), 10-20.

- Verroszta Zs. (2015). A tanári pályaelhagyás szaktárgyi mintázata. Educatio, (1), 607-618.

- Volkamer, M. (1993). Zweck oder Wirkung? Zur pädagogischen Instrumentalisierunk des Sport. Sportwissenschaft, (23), 423-429. 


\title{
Nagy Ágoston, Fintor GÁbor, Urbinné Borbély SzILVIA
}

\section{Az egyetemi testneveló tanárok tevékenységprofiljára ható testkulturális változások}

\begin{abstract}
Absztrakt
Jelen tanulmány az aktuális felsőoktatási testnevelést vette célba, mivel a mindennapos testnevelésből érkező diákok első hulláma 2016 szeptemberétől éri el a Debreceni Egyetemet is. Várhatóan új kihívások elé néz az egyetemi testkultúra átadása, és soha nem látott érdeklődésre is számíthatnak a testnevelő tanárok, akiknek a tevékenysége napjainkban változni látszik. Célunk, hogy az egységes felsőoktatási testnevelés tanmenet hiányában konkrét válaszokat kapjunk a tanítási feladatokról, teendőkről, a hatékony oktatási módszerekről. Megkerestük a választ, hogy ebben a folyamatban újradefiniálható-e a testnevelő tanárok tevékenységének profilja. Feltártuk a régiós jelentőségú Debreceni Egyetem testnevelésében szereplő tanárok és hallgatók aktuális tevékenységét. Az adatok kérdőíves válaszokból és a tantárgyfelvétellel kapcsolatos számadatokból származnak, melyet kiegészítettünk a tanárokkal készített interjúkkal. A mindennapos testnevelésből érkező nemzedék az egyetemi testnevelés és sport számára új lehetőségeket kínál. (1) A tanárok tevékenységére a hatékonyság a jellemző. (2) Átalakult a tanítástanulás rendszere. Kialakult egy szolgáltatásközpontú, modern, inkluzív oktatás, ahol a tanár szerepe felértékelődik, és a klasszikus vezetôi stílusok közül a coaching jellemzően a hatékonyság eszközévé vált. A testnevelési tanszékek feladata olyan hallgatóbarát pedagógia bevezetése lett, mely megfelel a hallgatók aktivizálásának s sikeres oktatásának. (3) Ebben az értelemben az egyetemi testnevelés nagyot lép a közeljövőben egy sportosabb életmódot kedvelő, egészségcentrikus fiatal értelmiség nevelése felé.
\end{abstract}

\section{Bevezetés}

A MEFS Hajós Alfréd tervének (2012) egyik célja, hogy az aktív sportolók száma növekedjen az egyetemi sportszíntéren, melynek hosszú távú következménye lehet az egész életen át tartó testedzés szemléletének valódi értékké válása. Ezen a területen kulturális késésben vagyunk az Európai Unió nemzeteihez képest.

A testnevelés az egyetemen is az emberi mozgásféleségekből, a foglalkoztatásba bevont személyekből, a tárgyi, infrastrukturális feltételrendszerből sajátos illetékességi kört határoz meg, fed le. Az ismereteket közvetítő és az ezeket befogadó személy(ek) pozitív attitűdje biztosítja a kívánt testi-lelki alkalmazkodást, s teremti meg a recipiens teljesítőképes tudásának stabil alapját (Biróné et al. 2011). 
„Az egyetemi testnevelő tanároknak - Biróné elmélete szerint - van az utolsó esélye, hogy szervezett keretek között segítsék a közoktatásban megkezdett oktatást, amely az érettségi után teljesen átalakul. A szomatikus és pszichés helyzetünk, közérzetünk, fittségi állapotunk gondozása már saját feladatunk, felelősségünk innentől. Amenynyiben kellő jártasságot szereztünk gyermek- és ifjúsági korban, azaz van megfelelő mozgástapasztalatunk, élményünk, s mi több, a felhasználható módszertani fogásokra is emlékezünk még, úgy jöhet az "önedzés". Minden más esetben szakemberhez, a sport adott területének szakértőjéhez célszerú fordulnunk" (Biróné 1994).

Az elmúlt 10-12 esztendőben számos kutatás vizsgálta a coaching szerepét, mint a tanítás-tanulás folyamatának eszközét a sportban és a testnevelésben (Cassidy et al. 2004; Jones 2006; Kidman 2004; Light 2004). A coaching ebben a megközelítésben fejlődést eredményezett a sportpedagógiában és a testnevelés oktatásának elméletében (Cassidy et al. 2004; Jones 2006). A kutatási eredmények a hallgatóközpontú megközelítés alkalmazását javasolják, amely „a tanitás, a coaching, a testnevelés és a sport különösen eröteljes kapcsolatára utal" (Penney 2006: 34).

A hallgatóközpontú kutatásunk felhívja a figyelmet a coaching lehetőségére, bár a nemzetközi irodalom számos problémára hívja fel a testnevelésben történő implementációjában (Kidman 2001; Light 2004).

\section{Témafelvetés}

\section{Miért a Debreceni Egyetem a kutatás célterülete?}

Sportkulturális szempontból pozitív tendenciák jellemzik az intézmény erőforrásait. Nem csupán régiós tekintetben, hanem országosan is értékadó a források feltárása és összekapcsolása. Számos területen történik hiánypótlás és fejlesztés, amelyek mưködőképessé teszik az egyetem innovatív sportéletét. Ezzel versenyképesebbé válik az egész intézmény piaci értelemben is, mely látványos változásokat generál a versenysportban, oktatásban, egészségügyben, továbbképzésekben is többek között.

\section{Ujjperspektiva}

A sporttevékenységet végző hallgatók gondolkodó, érző emberek, akiknek a szokásai és képességei befolyásolják a tanítás-tanulás sikerét. Mosston és Aseworth (1986) korábbi tanítási spektrum ötletére hívják fel a figyelmet Cassidy és mtsai. (2004), és javasolják az öt tanítási stílust, melyeket a coaching során ötvözve lehet alkalmazni (irányító, gyakorló, fordított, önellenőrző és problémamegoldó).

Azt javasolják, hogy ne csak átadjuk a tudást, hanem tegyük a hallgatókat önálló problémamegoldóvá, hogy kevésbé függjenek a tanártól. Ezért a tanárnak meg kell terveznie a környezetet, a tanítási célt és az alkalmazott pedagógiai módszert is.

Számos kutató hangsúlyozza a testnevelés és sport központi szerepét a társas kapcsolatokban (Grehaigne et al. 2005; Wallian \& Chang 2007; Wright \& Forrest 2007). A tanároknak meg kell érteniük, hogy a hallgatók ismeretei, tudásuk, amit magukkal 
hoznak, valamint a fizikai és társas környezet nagyban befolyásolja a tanulást. Tanulmányunk célja, hogy felhívja arra a figyelmet, hogy a sportoktatás nemcsak a technika és a mozgás tanulását jelenti, hanem a társas kapcsolatok alapját is képezi.

Az átfogó tanuláselméletek szerint az oktatás egy átalakító folyamat, mely nemcsak a sportban, hanem az életük más területein is aktívvá teszi a részt vevő hallgatókat.

\section{A coaching és a pedagógia}

Tanulmányunk a testnevelés tanításának szociokulturális aspektusát is vizsgálja, és a tanulásra lineáris folyamatként tekint, miközben a coachingra egyfajta tudományos folyamatként (például Cassidy et al. 2004).

A jelenlegi tanulmányok arra hívják fel a figyelmet, hogy a sportoktatás és a testnevelés-tanítás egyformán időszerú sportszíntér. Az átfogó gondolkodás kiemeli a tanulás komplexitását és a pedagógiai megközelítések szükségességét (például Light 2008).

\section{A sportcoaching definiálása}

A sportcoaching a sportolók mentális edzése: mentális állóképességük, adott esetben megküzdőképességük javítását értjük alatta. A cél egyértelmúen a teljesítmény javítása. A sportcoachingban ezzel szemben cél lehet egyfajta partneri viszony kialakítása, amikor is a versenyzőnek is lehet véleménye, elgondolása. Természetesen ettől a munkát még el kell végezni. Ez azt jelenti, hogy a versenyzőt a végrehajtó szintről a mellérendelt szintre kell emelni (Ilyés 2014).

Pedagógiailag továbbmegyünk a tanítás múvészetének vagy tudományának ötletétôl, és keressük a pedagógia inkluzivabb fogalmát, mely szerint "a tanitás minden tudatos és tervezett tevékenység, mely egy másik személy tudását fejleszti" (Watkins \& Mortimer 1999: 3). Bár ebből a tanítás-tanulásból indulunk ki, felismertük a nem tudatos implicit tanulás szerepét, mely előfordul a mindennapi társas életben, melyet Lave és Wenger (1991) azonosított tanulási elméletként, és a Bourdieu-féle (1986) tőke- és habituselméletet.

\section{Kutatási anyag és módszer}

\section{A kérdöív bemutatása}

A vizsgálat survey-módszerrel zajlott. A kérdőív kitöltésének idején a testnevelésre kötelezett hallgatók száma megközelítőleg 4000 hallgató volt. A tanulmányi rendszer segítségével EvaSys kérdőíveket küldtünk ki, melyre 2950 értékelhető választ kaptunk. Ilyen mértékủ válaszadás elég ritka, ez is arra utal, hogy a hallgatók számára jelentőséggel bír a sporttevékenység. Természetesen a kérdôív postázásának időpontja időszerú volt, hiszen a testneveléstantárgy-felvétellel egy időben történt, s mivel a hallgatóknak a diplomaszerzés feltétele e kritériumok teljesítése, így reflektorfényben tarthattuk a kérdéseket is. 
Öt témakörben készítettünk kérdéssort. Könnyen és gyorsan megválaszolható kérdéseket tettünk fel. Időben körülbelül 10 percre volt szükség a kitöltéshez.

A hallgatók sportolási szokásai fontos helyzetjelentést képeznek. A sportolásra fordított idejük, ismereteik a DEAC-ról, jelenlegi sporttevékenységük és az erre fordított költség, a választott sportáguk szerepeltek a kérdések között, de azt is meg akartuk tudni, milyen súlya van életmódjukban a rendszeres sportolásnak.

A testneveléssel kapcsolatos kérdéscsoport segített meghatározni, hány félév kötelezettsége van a kitöltő személynek, ebből hányat teljesített eddig. Itt értékelhették a testnevelési feltételeket, az órarendbeosztást, az egyetemen kívüli szerződéses külső szolgáltatásokat, táborokat.

A hallgatók sportlétesítményekkel kapcsolatosan is véleményt formálhattak. Segítség volt megismerni, milyennek értékelik a középiskolához képest az egyetemi sportinfrastruktúrát és a rendelkezésre állásukat. Elmondhatták, hogy szükségesnek tartják-e a sportlétesítmény-fejlesztést.

A sport megítélésével kapcsolatos kérdések között összehasonlítást tettek a középiskolai és egyetemi diáksport és testnevelés megítélésével kapcsolatosan. Itt tudtuk meg, hogy a válaszadó kapott-e már egyetemi sportösztöndijat és azt is, hogy jár-e rendszeresen valamilyen városi sportversenyre szurkolóként. Szerettük volna megtudni, hogy fontos-e számukra az egyetemi színekben történő versenyzés. Ebben a kérdéssorban mondták el, hogy milyen mértékben értékelte a felvételi eljárás a sporttevékenységet. Megtudhattuk, hogy elégedettek-e az egyetemi sportinformációs rendszerrel és ismerik-e a kiemelt sportrendezvényeket.

A testnevelésre kötelezett hallgatók érdekében áll, hogy alaposan ismerjék a testneveléssel és a rendszeres sportolással kapcsolatos lehetôségeket. Összefoglalva az egyetemi sportprogram aktuális szerepét, lehetőségeit, helyzetét és müködésének értékelését kívánta feltérképezni a kérdőív. Ezt a célt úgy sikerült elérni, hogy a kérdőív reprezentatív volt.

A minta elemszáma 2950, a reprezentativitás teljesül a 15 kar szerinti megoszlásra, hiszen az alapsokaságban is hasonlóan alakulnak az arányok a karok tekintetében. A minta hitelességét a megbízhatósági elemzéssel is igazoltuk, az ún. Cronbach-alfa mutató használatával. Mivel a mutató értéke minden esetben meghaladta a kritikus 0,6-os értéket, így a mintát hitelesnek tekintettük (1. ábra). 


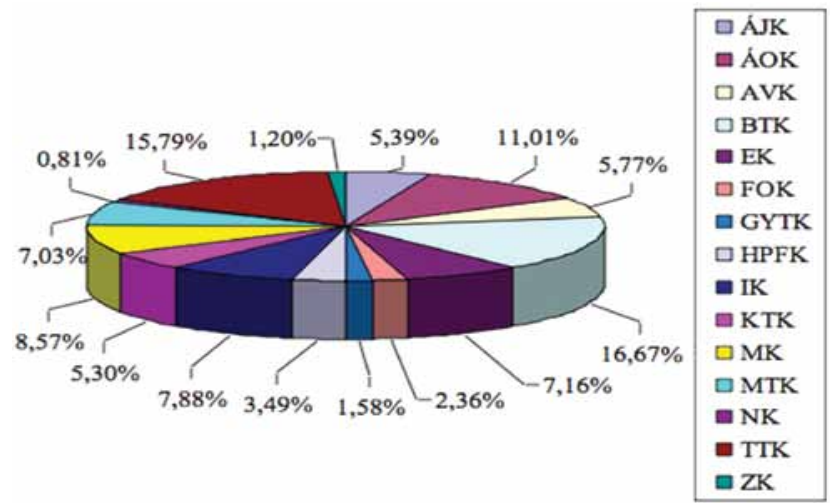

1. ábra. A minta karonkénti megoszlása $(\mathrm{N}=2950)$.

Forrás: saját kutatás

Az egyetemi testnevelés követelményeirôl a Testnevelés ügyrend szolgál információval. Több mint húsz fóállású és óraadó testnevelő tanár vesz részt a kötelező testnevelésben. Feltártuk a régiós jelentőségű Debreceni Egyetem testnevelésében szereplő tanárok és hallgatók aktuális tevékenységét. Az intézmény mintául szolgál, ahol hetente 4-5000 hallgató vesz részt a szervezett testnevelésben. Az adatok - a tanárokkal és a hallgatókkal készített - kérdőíves válaszokból és a tantárgyfelvétellel kapcsolatos számadatokból származnak, melyet kiegészítettünk a tanárokkal készült interjúkkal. A interjúk során kapott válaszokat összehasonlítottuk a kérdőívben szereplő adatokkal és a tantárgyfelvételi számokkal.

\section{A tanárok}

A kikérdezett tanárok anonimitását megóvandó, összefoglaljuk név nélkül a rájuk jellemző adottságokat és képességeket, melyek alapján egy általános profil is kirajzolódik. Négy tanárt emeltünk ki. Két férfit és két nőt. Vannak közöttük, akik kb. 10 éve tanítanak az egyetemi testnevelésben, mások több mint húsz esztendeje. A 2. táblázat bemutatja, hogy viszonylag homogén a tanárok korosztálya. Nem várható lényeges változás a szeméyi állományban $\mathrm{kb}$. húsz évig.

Nő 45 - tíz évnél régebben oktat a testnevelésben. Egyetemi végzettsége van. Fő sportága egy labdajáték, de számos képzésen vett részt. Ma már személyi edzéseket is tart. A versenysportban csak szervezőként vesz részt, előtte éveken át sikerrel edzősködött. Jól beszél angolul. Elméleti sportórákat is tart. Vannak vezetői tapasztalatai.

Férfi 50 - húsz évnél régebben oktat az egyetemi színtéren. Egyetemet végzett. Egyéni sportban volt edző. A szabadidő-jellegű rekreációs sportágakban szívesen dolgozik. Kedveli a tradicionális jellegű irányított órákat. Nem beszél angolul.

Nő 45 - fitneszsportágakban érdekelt. Főiskolát végzett. Személyi edzésekkel és önálló edzésekkel egészíti ki a munkáját. Versenysportban nem dolgozik. Sok új sportág irányában érdeklődik. Továbbképzésekre jár. Jól beszél angolul. 
Férfi 45 - versenysportban is érdekelt. Egyetemet végzett. Sok sporteseményt szervez. Kevésbé nyitott az új trendi sportágak felé. Angolul jól beszél. A sporttudományban is keresi az innovatív módszereket. Általában sportjátékórákat tart. Vannak vezetôi tapasztalatai. Továbbképzéseket vezet. Szövetségi munkát is végez.

\section{A tanári kérdöívról}

A válaszokkal megismertük az intézményi változásokat, intézkedéseket, a minőségbiztosítást, követelményeket, a teljesítés lehetőségeit, az órai részvételt és hatékonyságát, a sportági palettáról alkotott értékrendjét, a munkahelyi kultúrát, esélyegyenlőséget, a gyógytestnevelést, környezeti feltételeket, problémákat s a tanárok innovatív javaslatait.

\section{Eredmények}

A kutatás során rendkivül részletes képet kaptunk a hallgatók konkrét sportolási szokásaival kapcsolatosan. Ebben a tanulmányban elsősorban azokat az eredményeket mutatjuk be, melyek szoros összefüggésben vannak a tanárok tevékenységének változásaival, s amelyek felhívják a figyelmet a frissen érkező diákok lehetséges igényeire. A tanulmány jóval nagyobb léptékủ és további értelmezéseket is kínál attól függően, hogy melyik aspektust kívánjuk reflektorfénybe állítani. A mindennapos testnevelés bevezetése alapjaiban változtatta meg a magyar oktatásban a testkultúra szerepét, így a kutatási programunk újraértelmezését is szükségessé teszi.

Korábbi kutatási programjaink vizsgálták:

1. a hallgatók szokásait,

2. a szervezetet, munkahelyi kultúrát,

3. a sportlétesítményeket,

4. a sportprogram fejlesztési lehetőségeit,

5. a hallgatói értékrendet,

6. ezúttal a tanárok tevékenységprofilját kutattuk, mert úgy gondoljuk, hogy nemcsak a közoktatásban, hanem a felsöoktatási sport szintjén is nagy jelentösége van a testneveló tanárok munkájának, oktatási módszereinek.

A kiinduló helyzet, hogy a testkultúra hármas hatása egy önálló rendszerként épül be az egyetemes kultúrába (2. ábra). A forrásai állandó kölcsönhatásban vannak egymással. A leggyengébb pontja jellemzi az egész rendszert, így a fejlettebb egészségtudattal rendelkező európai nemzetekhez képest csökkentenünk kell a kulturális késést, mely egyben a teljesebb életet élő és egészségesebb ember koncepciójára neveli valamennyi generációnkat. Így lesz igazi esélye a következő nemzedéknek egész életen át egészségesebbnek, fittnek lenni, hogy teljesítőképességük növekedjen, és az életminőségük javuljon hazánkban. 


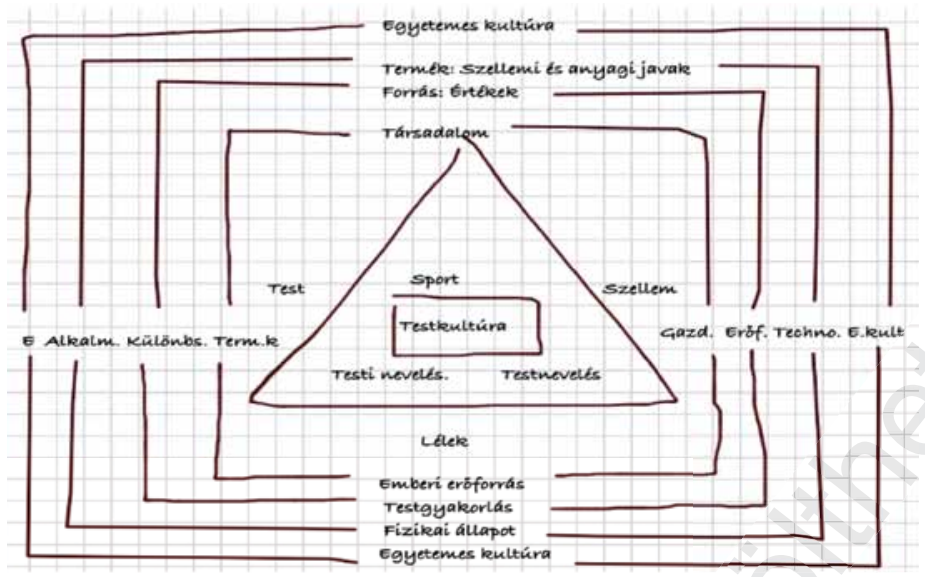

2. ábra. A testkultúra rendszere (saját szerkesztés)

Ezek a korábbi kutatások több eredményt találtak, melyek az alábbi rendszerelemeket jelölték meg katalizátorként.

\section{Emberi eröforrások:}

1. Sporttudományi Koordinációs Intézet

2. Sporttudományi képzés/szenátus állásfoglalása

3. Kutatási eredmények

4. Hallgatói értékrend és sportolási szokások

5. Sportolási szokások és a mindennapos testnevelés teljes vizsgálata a közoktatásban

\section{Környezeti eröforrások:}

1. Létesítményfejlesztés

2. Akadémiai rendszerek folyamatos fejlesztése

3. Müködő rendszer részei

4. Karok, középiskolák, általános iskolák

5. Sportolás színterei

6. Sporttudományi labor - sportegészségügy fejlesztése

\section{Gazdasági eröforrások:}

1. Taotámogatás

2. Állami támogatások

3. Pályázatok

4. Sportklaszterek

\section{Társadalmi eröforrások:}

1. Diákváros, az egyetem régiós szerepe

2. Az egyetem és az önkormányzati, illetve a kormányszervek kapcsolata

3. Együttműködés a sportági szakszövetségekkel 
A mindennapos testnevelésböl érkezô nemzedék az egyetemi testnevelés és sport számára üj lehetöségeket kinál. Ezért rendkivül fontos, hogy megismerjük az aktuális értékeket, sportági választásokat, hatékonyságot, a félévente jellemzó tendenciákat s a tanárok megváltozott tevékenységét, amely túlmutat a korábbi felsöoktatási testnevelési célokon, feladatokon, eszközökön, szokásokon, tanitási-vezetési módszereken.

\section{A testnevelő tanárok profilja}

A tanárok féléves átlagban heti 20 testnevelésórát tartanak. Ez lényegében 10 alkalmat jelent, ahol az egy tanárra jutó átlagos létszám 16-20 fő között található. Az órákon jellemző, hogy 10-20\%-ban külföldi hallgatók is részt vesznek, amely új kihívásokat teremt a tanárok számára. A munkakörülményekkel, az életritmussal, felszerelésekkel, innovatív lehetőségeikkel elégedettek, de életminőségüket átlagosnak tartják.

Az órákat különböző napszakokban tartják, nem ritka, hogy az esti órákban vannak a foglalkozások, melyekre a felkészülés szinte naponta történik meg. Nem lehetséges az általános tanmenet követése, mert a kialakult csoportokban teljesen eltérő felkészültségű, képességư, motiváltságú, összetételủ hallgatók vannak. Legtöbbször nincs is nemekre bontás, ami plusztervezést igényel. Számos tanárnak van egyszerúsített óravázlata. Sokan választják a felkészüléshez a videózást, amely segít lépést tartani a változó trendek megismerésével és oktatásával. A tanárok a hagyományos labdajátékok mellett meghirdetnek ütős játékokat is. Nagy százalékban tartanak fitneszórákat, úszást, speciális gimnasztikát. Általában az egyetemre felvételt nyert alsóbb éves hallgatók veszik fel elsősorban az órákat. Az idősebbek inkább a délutáni, esti szolgáltatások, klubok, szakcsoportok foglalkozásaira járnak. Az első két év végére nagy százalékban teljesítik a két féléves kötelezettségüket.

Elengedhetetlen, hogy egyszerúsített sportmarketing-tevékenységet folytassanak, mert ennek hiányában a meghirdetett táborok, sportnapok, házi versenyek nem lennének sikeresek. Bemutatkozó szövegekkel színesítik a félév elején meghirdetett óráikat. Rendszeresen szólítják meg a hallgatókat plakátokon, hirdetményeken keresztül. Nem ritka, hogy videóval, fényképekkel ellátott üzeneteket készítenek.

Rendszeres, hogy sporteseményeket szerveznek. Ezek - a tanárok egyéni érdeklődésének megfelelően - verseny- vagy szabadidősport-jellegúek.

$\mathrm{Az}$ órák sok esetben sportszolgáltatás-jellegüek. Gondoljunk például a spinningórákra, amelyekért a fitneszklubokban nagy tagdíjat kérnek el. A tanácsadás és az egyéni edzéstervek elkészítése is jellemző.

A tanárok új feladatköre a folyamatos kapcsolattartás a hallgatókkal (Facebook, e-mail, Neptun üzenet, chat...), az alumnidiákokkal, a kollégákkal; és az aktuális diákok is igénylik az információátadást, melyek szükségesek a sikeres múködéshez, hiszen az új rendszerủ egyetemi testnevelésben ez szükségessé vált.

A magas színvonalú munka elófeltétele, hogy ne legyenek elégedettek a tanárok a meglévő szakmai tudásukkal, ezért érdeklődésüknek megfelelően vesznek részt to- 
vábbképzéseken. Így a felkészültségük valóban versenyképessé vált a sportiparban tevékenykedő sportoktatókkal. Közülük többen vállalkozóként is dolgoznak a szabad idejükben.

Fontos szerepkör, hogy kapcsolatot tartanak a helyi vagy az országos szakszövetségekkel, hiszen többen is részt vesznek például az edzőképzésekben, melyeket a szövetségek szerveznek.

A képzettségüknek köszönhetően többen aktívan vesznek részt a versenysportban. Felkészítéssel és versenyeztetéssel is foglalkoznak. Új lehetőség a sporttudományos oktatásban történő oktatói részvétel, melynek előfutára a szabadon választható sporttartalmú elméleti kurzusok megtartása.

A napi, heti rutinhoz tartozik a jelenlétek, hiányzások, felmérési eredmények rögzítése. Utóbbi párosulhat néhány tanár esetében tudományos igényű kutatással is.

A sportszerek megóvása és karbantartása is egy jellemző tevékenység. Ehhez kapcsolódik a sportlétesítmény gondozása, házirendjének betartása.

Az önképzés a szabad időre marad sokuk esetében. A felgyorsult világunkban bőven van lehetőség, hogy magyar és angol nyelvü szakanyagokkal ismerkedhessenek meg. Ennek egyik eredménye, hogy vannak, akik a továbbtanulást választották. A posztgraduális képzés során MSc-t, szakedzői diplomát, gyógytestnevelői diplomát, $\mathrm{PhD}$-t szereznek. Ők aktívabbak a kutatásokban is. Megtalálhatjuk sokukat a sportkonferenciákon előadóként is. Vannak, akik továbbképzéseken, konferenciákon adják elő aktuális gondolataikat.

Elismerésre méltó, hogy időben tájékoztatják az egyetemi és a helyi médiát a sportprogramok eredményeiről. Félévente beszámolási kötelezettségük van. Ezek a jelentések a nehézségeket, eredményeket, ötleteket is tartalmazzák. A versenyekre történő utazások szervezése, lebonyolítása is a hatáskörükbe tartozik.

Miután az oktatási, vezetési módszerek speciálisak, így példaként is tekintenek rájuk a sportolást értékként megélő hallgatók, így az aktív sportolás is a profil szignifikáns része.

Felelősségteljes feladat a sportprogram és a benne dolgozó személyek ismerete. Így módjuk van a széles körben végzett tehetségkutatásra és a tehetséggondozásra egyaránt.

Miután a profil számos területen jelent önálló működést, a felmerülő problémákat egyénileg oldják meg sok esetben, ezért naponta vannak döntéshelyzetben. Így vállalják a felelősséget és teszik munkájukat értékesebbé.

A tanárok tevékenységére a hatékonyság a jellemző (1. táblázat). A meghirdetés a testnevelésre kötelezettek számához igazodik. A testnevelést felvettek számából látszik, hogy egyfajta túlkínálat jellemző, viszont az is olvasható, hogy csupán 77 százalékuk kap aláirást, mely az aktivitásukat mutatja. A szám szomorú, hiszen heti egy alkalom teljesítéséről van szó. 
1. táblázat. A meghirdetett kurzusok teljesítésének hatékonysága 8 év átlagában

\begin{tabular}{|c|c|c|c|c|c|}
\hline \multicolumn{6}{|c|}{ Magyar hallgatók (SI-001) } \\
\hline & $\begin{array}{l}\text { Kurzus } \\
(\mathrm{db})\end{array}$ & $\begin{array}{l}\text { Meghirde- } \\
\text { tett létszám } \\
\text { (fő) }\end{array}$ & $\begin{array}{l}\text { Felvett } \\
\text { létszám } \\
\text { (fó) }\end{array}$ & $\begin{array}{l}\text { Aláírást } \\
\text { kapott } \\
\text { (fó) }\end{array}$ & \\
\hline Böszörményi úti campus & 32 & 642 & 612 & 505 & $82,5 \%$ \\
\hline Egyetem téri campus & 67 & 1975 & 1803 & 1455 & $81 \%$ \\
\hline Klinikai campus & 42 & 865 & 664 & 586 & $88 \%$ \\
\hline Múszaki campus & 33 & 544 & 497 & 401 & $81 \%$ \\
\hline Fizetős szolgáltatások & 28 & 1011 & 725 & 382 & $53 \%$ \\
\hline Versenysport & 1 & & 106 & 68 & $64 \%$ \\
\hline Eü.-i felmentés & 1 & & 51 & 48 & $94 \%$ \\
\hline Összesen: & 204 & 5037 & 4458 & 3445 & $77 \%$ \\
\hline \multicolumn{6}{|c|}{ Külföldi hallgatók } \\
\hline & $\begin{array}{l}\text { Kurzus } \\
(\mathrm{db})\end{array}$ & $\begin{array}{l}\text { Meghirde- } \\
\text { tett létszám } \\
\text { (fö) }\end{array}$ & $\begin{array}{l}\text { Felvett } \\
\text { létszám } \\
\text { (fö) }\end{array}$ & $\begin{array}{l}\text { Aláírást } \\
\text { kapott } \\
\text { (fó) }\end{array}$ & \\
\hline SI 005 (Agrár karok) & 1 & 5 & 5 & 5 & $100 \%$ \\
\hline $\begin{array}{l}\text { SI } 004 \text { (Tudomány egye- } \\
\text { temi karok) }\end{array}$ & 67 & 212 & 71 & 37 & $52 \%$ \\
\hline SI 003 (Orvosi karok) & 50 & 978 & 671 & 451 & $67 \%$ \\
\hline
\end{tabular}

Forrás: saját kutatás

A külföldi hallgatók a világ minden tájáról érkeznek, ez pedig sportkulturális diverzitást is feltételez. Ez további kutatást kínál számunkra. E hallgatók elsősorban az orvosi karokra járnak, és összességében passzívabban teljesítik a félév követelményeit.

Átalakul a tanítás-tanulás rendszere. Kialakulóban a szolgáltatásközpontú, modern inkluzív oktatás, ahol a tanár szerepe felértékelődik, és a klasszikus vezetői stílusok közül a coaching jellemzően a hatékonyság eszközévé válik. A testnevelési tanszékek feladata olyan hallgatóbarát pedagógia bevezetése, mely megfelelő a hallgatók aktivizálására s sikeres oktatására. A legnyilvánvalóbb, hogy olyan sportági palettát kell kialakítani, mely megfelel a modern és dinamikusan változó hallgatói igényeknek.

Az alábbi táblázat felhívja a figyelmet, milyen mértékben érdemes szakítani a hagyományos testnevelési kurzusokkal, hiszen a csoportközpontú csapatjátékokat alacsonyabb hatékonysággal teljesítik, mint az egyéb kategóriájú órákat. Az is jól látható, hogy van egy komolynak tekinthető fizetőképes hallgatói réteg. 
2. táblázat. Mit választanak a hallgatók? Nyolcéves átlagban

\begin{tabular}{|l|c|c|c|c|}
\hline & $\begin{array}{c}\text { Meghirdetett } \\
\text { kurzusok száma }\end{array}$ & Felvették & Teljesítették & $\begin{array}{c}\text { Kurzushaté- } \\
\text { konyság }\end{array}$ \\
\hline Labdás órák összesen & 105 & 1352 & 1042 & $77 \%$ \\
\hline Egyéb órák összesen & 189 & 3128 & 2514 & $80 \%$ \\
\hline Fizetős órák összesen & 28 & 725 & 382 & $53 \%$ \\
\hline Összesen: & 322 & 5205 & 3938 & $76 \%$ \\
\hline
\end{tabular}

Forrás: saját kutatás

Egy-egy speciális sportág jellemzi a tanár érdeklődési körét, képzettségét. A 3. ábrán a tanárokra bontott hallgatói létszámok mutatják a terhelésüket. Ez jellemzi a hatékony sportági hirdetést. E táblázatban nem szerepelnek a csapatjátékok, melyeket - hazai viszonylatban - hagyományos sportágnak tekintettünk a vizsgálat során.

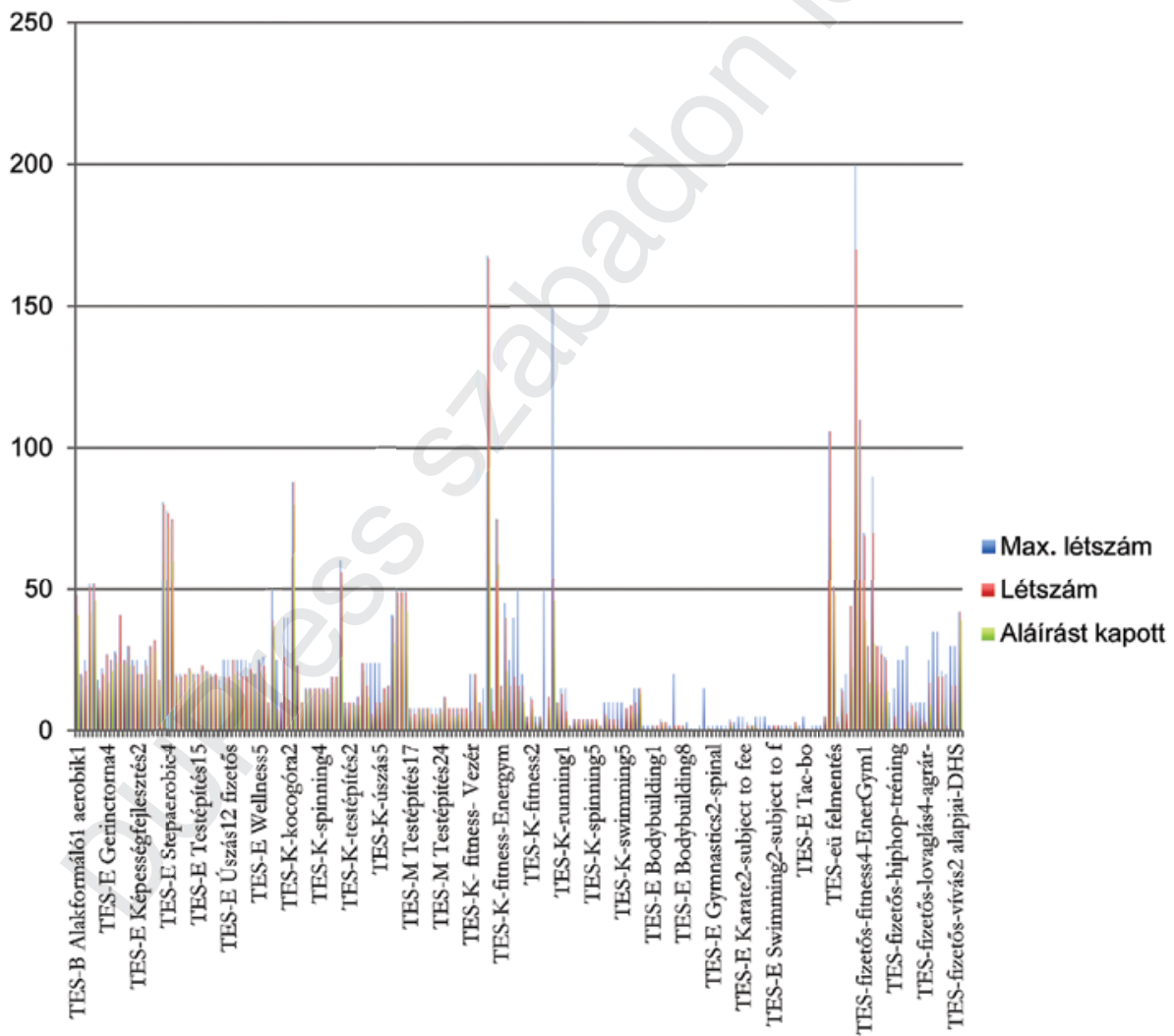

3. ábra. A hallgatók választott kurzusai: nem hagyományos sportágak Forrás: saját kutatás 
A hagyományos sportágak mellett növekvő mértékben dominálnak az új trendeknek megfelelő sportágak, melyeket a hallgatók szívesebben vesznek föl és a teljesítésük is nagyobb hatékonyságot mutat. Nyilvánvaló, hogy szükség van azokra a sportágakra, kurzusokra, ahol a hallgatók nagyobb figyelmet kapnak. Szívesen formálják testüket, ha újdonságot éreznek benne. Más a viszony a tanárral és több idő jut a mentális tréningre, ami az egészséges életmódra vágyó hallgatók számára megerősítéseket és extra motivációt jelenthet. Így átalakult a domináns vezetői stílus, mert hatékonyabbnak bizonyulnak az inkluzív jellegú módszerek. Természetesen függ a csoporttól és a tanárok elképzeléseitől a választott metódus. Az ilyen típusú órákat nem lehet tradicionálisan és autokratikus módszerrel megkedveltetni.

A hatékony, motiváló vezetési stílus kiválasztása érdekében érdemes többféle oktatási formát vizsgálni, melyek valójában tanítási stratégiákat jelentenek. Ezek közül a hallgatók legmegfelelőbb fejlődése érdekében választ a testnevelő tanár. Mosston (1994) egy skálát rendezett össze, mely az autokrata vezetôi stílus (amelyet ő oktatócentrikus vezetési stílusnak nevezett el) és a legdemokratikusabb, az úgynevezett tanítványcentrikus stílus közötti átmenetet jelzi. Ezt összesítve „Spektrumnak” nevezte el.

Oktatócentrikus (autokratikus) «--------» Tanítványcentrikus (demokratikus) ««----»» Irányító Gyakorló Fordított Önellenőrző Bevonó Felismerő Problémamegoldó stílus

4. ábra. A „Spektrum”.

Forrás: saját szerkesztés

Az irányító stílus során (mely a tradicionális testnevelésórákon a leggyakrabban megnyilvánul) a tanár határozza meg az óra minden egyes részletét. Ahogy a tanítványcentrikus stílusok irányába haladunk, úgy kap mind több teret a tanítvány, hozhat nagyobb részben döntéseket, és válik a tanulás a tanártól függetlenné. A „Spektrum” végén a problémamegoldó típusú oktatási stílusok állnak, amikor a tanár egy adott feladatot tár a hallgató elé, aki szabadon, képességeinek megfelelóen választja ki a leghelyesebbnek vélt megoldást vagy megoldásokat. Bár ez a típusú oktatási módszer kerülőútnak tủnhet, és bizonyos mértékig lassíthatja a tanulási folyamat ütemét, azonban a hallgatókat sokkal nagyobb mértékben kényszeríti gondolkodásra, illetve elősegíti mozgásos tapasztalatszerzésüket (Báthori 1994). Ez a módszer az egyetemi korosztály számára előrevetíti az egész életen át tartó testedzés önálló tervezését és a tudatosságot.

A „Spektrumon” jobbra haladva az oktatási stílusokon keresztül fokozatosan kap több és több lehetőséget a tanítvány a döntéshozatalra. Mindenképpen lényeges azonban az, hogy a tanárnak nem csupán teret kell biztosítania a döntéshozatalra, hanem meg kell tanítania a tanítványt a saját döntései kiértékelésére is. Ez úgy érhető el, hogy a tanár és a hallgató közösen értékelik ki a megoldás(ok) helyességét és hatékonyságát a feladatokat követően. Mivel a hallgatóban így kialakul egy önértékeló mechanizmus, képes lesz a későbbiekben a különböző helyzetekben jó döntéseket hozni, illetve felismerni a kevésbé jó döntéseket, és ezáltal tanulni a saját hibáiból. 


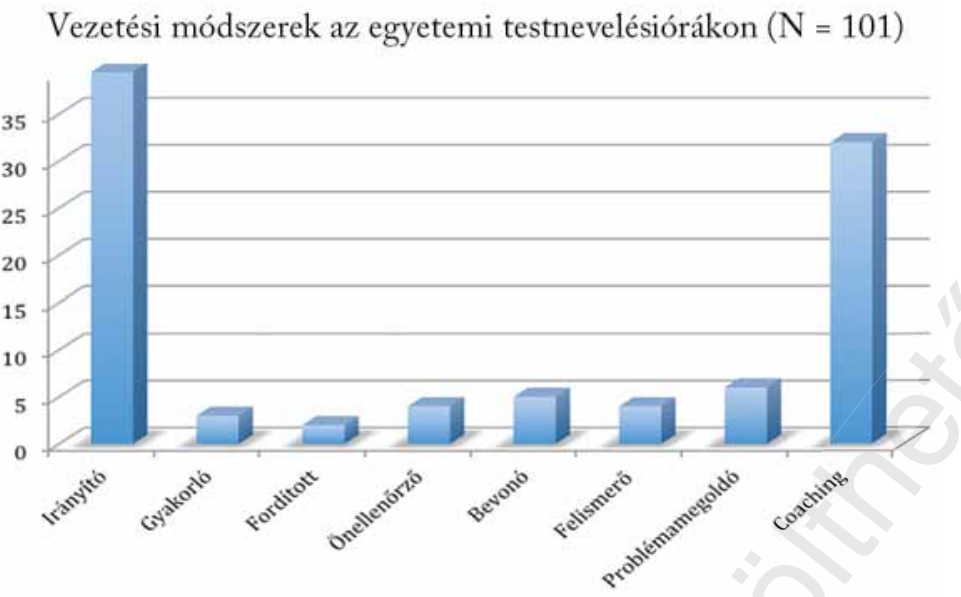

5. ábra. Az alkalmazott vezetési stílusok az egyetemi színtéren $(\mathrm{N}=101)$. Forrás: saját kutatás

Az ötödik ábra azt a tendenciát mutatja, mely alapján látható, hogy a tanítás folyamata, módszere átalakulóban van. Vannak átmeneti stílusok az irányító stílus és a coaching között, és egyetlen félévben sem várható, hogy ezek ne legyenek jelen bizonyos mértékben, azonban az irányt jól érzékelhetjük a táblázatban. Ebben az értelemben az egyetemi testnevelés nagyot lép a közeljövőben egy sportosabb életmódot kedvelő egészségcentrikus fiatal értelmiség nevelése felé. Alapelv, hogy a hallgatók igényeihez rendeljük a sportprogramot. Naprakészen ismerjük a szokásaikat, elérhető szabad idejüket. A sportolási trendek ismeretében a tanárok keresik a továbbképzésük lehetőségét, hogy olyan területeken szerezzenek szakmai jártasságot, amelyek birtokában könnyedén birkóznak meg a kihívásokkal egy multikulturális környezetben, így képessé válnak a sportprogramok tartalmának adaptálására, új eszközök tudományos és gyakorlati használatára, sőt képesek lesznek individualizálni a tanítási módszereket, hogy a képességek és kompetenciák szélesebb köréhez alkalmazkodjanak.

Az egyetemisták sportolási szokásai alapján felmerült az igény egy összetettebb, értékesebb életmódra. A hallgatók is úgy szeretnének teljesitő́képes energiához jutni, hogy tudatosabban élnek és szeretnék megtervezni az energiájukat. A négy legfontosabb energiaigényú humán területet magyarázza a 6 . ábra, melyet a testnevelési és sportkurzusok során is tudatosíthatnak a sportszakemberek. E rendszernek a tudatositása vitális kérdés és szorosan összefügg a hatékonysággal, illetve a vezetői stílus megválasztásával. A hallgatók bevonása sokszínúbbé tehető. 


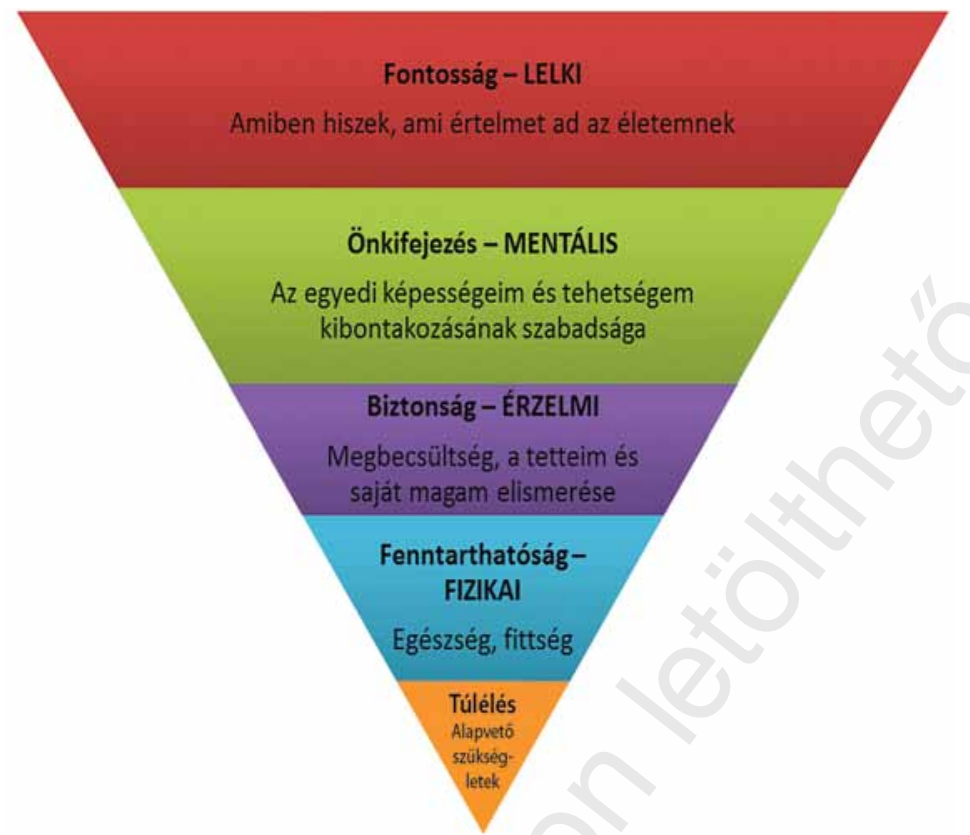

6. ábra. Energiapiramis (alapvető szükségleteink).

Forrás: Loehr \& Schwartz 2003

Fizikailag, lelkileg, mentálisan és érzelmileg egyaránt. Négy kiemelt területet azonosíthatunk, melyek kiegyensúlyozása elengedhetetlen a sikeres és egészséges életvitelhez az egyetemi hallgatók körében is.

1. Fizikai (energiánk mennyisége): Az összes energiánk alapja, mely a következő elemekből áll: légzés, alvás, táplálkozás, mozgás, feltöltődést biztosító tevékenységek.

2. Érzelmi (energiánk minősége): Hogyan tudunk érzelmi állapotainknak tudatában lenni és hogyan vagyunk képesek a stressz és a negatív helyzetek kezelésére.

3. Mentális (fókusz biztosítása): Figyelmünk irányításának képessége. Ha tudunk egy dologra fókuszálni, akkor hatékonyan használhatjuk mentális energiánkat.

4. Lelki (életünk célja): A lelki szint hatással van a három másik energiaforrásra. Megmutatja, mennyire vagyunk összhangban küldetésünkkel, mennyire vagyunk húek alapértékeinkhez. Belsó békét akkor érzünk, ha megvan ez az összhang (Loehr \& Schwartz 2003). 


\section{Következtetés}

Újszerủ módon kívántuk bemutatni, értékelni, hogy néhány kiemelt testnevelési és testkulturális feladatnak megfelelően milyen színvonalon valósul meg a testkultúra átadása az egyetemi sportszíntéren.

Sikerült tehát definiálni az egyetemen tanító testnevelő tanárok tevékenységprofilját - tanári és szakemberi professzióit - az aktuális testkultúra környezetében. Pontos képet kaptunk, kinek és mit tanítanak, milyen gyakorisággal, miért éppen az adott sportág szerepel a palettán, hogyan szervezik a kurzusokat, milyen kiegészító feladatokkal érik el a sportprogram sikerét. Láthatóvá tettük a Master-plant, illetve a nehézségeket, melyekkel féléves gyakorisággal találkoznak a tanárok. Összefoglaltuk, milyen tradicionális, motivációs, értékelő és egyéb kihívásokkal kell megbirkózniuk. Egyértelmú, hogy mekkora a szerepük a tehetségkutatásban, a tehetséggondozásban és a rendszeres testedzés, illetve az egészséges életmód szemléletének átadásában.

A sporttudományos képzés, az új sportágak megismerése, az új eszközök kipróbálása, az angol nyelvú oktatás, az elméleti oktatás, a sportszakemberképzés, a változó hallgatói értékrend megismerése, az átállás a szolgáltató jellegủ foglalkozásokra, a minőség biztosítása, a sportkutatások olyan irányok, amelyekkel naponta találkoznak az egyetemi színtéren a testnevelő tanárok. Az egészséges életmód hirdetése és a testkultúra területén tapasztalható kulturális késés csökkentése erősödő kihívást jelent valamennyi tanár számára az egyetemi testnevelésben és sportban. A következő évek rengeteg érdekes és ismeretlen helyzetet állíthatnak elénk, hiszen elvileg egy sokkal aktívabb generáció hulláma éri el az egyetemi sportszínteret.

\section{Hivatkozott irodalom}

- Báthori B. (1994). A testnevelés elmélete és módszertana. Budapest, MTE.

- Bourdieu, P. (1986). Distinction: A social critique of the judgement of taste. London, Routledge.

- Biróné dr. Nagy E., Bognár J., Farkas J., Gombocz J., Hamar P., Kovács A. T., Mészáros J., Ozsváth K., Rétsági E., Rigler E., Salvara, I. M., Szabó B., Tihanyiné Hôs Á., Vináné Kokovay Á., Dialóg Campus Kiadó-Nordex Kft. (2011). Sportpedagógia - Kézikönyv a testnevelés és sport pedagógiai kérdéseinek tanulmányozásáboz. Pécs, Pécsi Tudományegyetem, Szegedi Tudományegyetem, Nyugat-magyarországi Egyetem, Eszterházy Károly Fóiskola, Dialóg Campus Kiadó-Nordex Kft.

- Biróné Nagy E. (1994). A testnevelés és sporttudomány értelmezése (Vitaanyag). Budapest, TF. 1-6 p.

- Glaser, B. G. \& Strauss, A. L. (1967). The discovery of grounded theory: Strategies for qualitative research. London, Weidenfeld and Nicholson.

- Grehaigne, J. F., Richard, J. F. \& Griffin, L. L. (2005). Teaching and learning team sports and games. New York, Routledge Falmer. 
- Ilyés Gy. (2014). Sport-coaching. Magyar Coachszemle 2014. május 18. Forrás: http://coachszemle.hu/cikkeklistaja/42-iranyok/469-a-sport-coaching. Utolsó letöltés: 2016. 09. 05.

- Kidman, L. (2001). Developing decision makers: An empowerment approach to coaching. IPC Print Resources, 2001, 159 oldal.

- Lave, J. \& Wenger, E. (1991). Situated learning: Legitimate peripheral participation. Cambridge, Cambridge University Press.

- Light, R. (2004). Coaches'experience of Game Sense: Opportunities and challenges. Physical Education and Sport Pedagogy, 9 (2), 115-32.

- Light, R. (2008). An examination of complex learning theory, its epistemology, its assumptions about how we learn and implications for physical education. Journal of Teaching in Physical Education, 27 (1), 21-37.

- Loehr, J. \& Schwartz, T. (2003). The power of full engagement: managing energy, not time, is the key to high performance and personal renewal. New York, Free Press. 3.

- Mosston, M. \& Ashworth, S. (1986). Teaching physical education. $3^{\text {rd }}$ ed. Columbus, $\mathrm{OH}$, Merrill Pub Co.

- Penney, D. (2006). Coaching as teaching. In. Jones, R. L. (ed.): The sports coach as educator (pp. 25-36). London, Routledge.

- Wallian, N. \& Chang, C. W. (2007). Language, thinking and action: Towards a semio-constructivist approach in physical education. Physical Education and Sport Pedagogy, 12 (3), 289-311.

- Watkins, C. \& Mortimer, P. (1999). Pedagogy: What do we know? In Mortimore, P. (ed.): Understanding pedagogy and its impact on learning (pp. 1-19). London, Paul Chapman Publishing.

- Wright, J. \& Forrest, G. (2007). A social semiotic analysis of knowledge construction and games centred approaches to teaching. Physical Education and Sport Pedagogy, 12, (3) 273-87.

\section{Dokumentum}

- A Debreceni Egyetem testnevelés ügyrendje. Forrás: https://portal.agr.unideb.hu/ media/Testneveles_ugyrend_uj_13774.pdf. Utolsó letöltés: 2016. 09.08. 


\title{
Hideg Gabriella
}

\section{Fair play, neked mit jelent? Kárpát-medencei fiatalok véleménye a fogalomról}

\begin{abstract}
Absztrakt
A fair play fogalma eredetileg a sportból származik, amely mára egy nemzetközileg ismert fogalommá vált. Éppúgy jelen van az üzleti életben, a politikában és a társadalmi lét minden szintjén, mint a sportban.

A hazai szakirodalom ugyan szegényesnek mondható e témakörben, de a nemzetközi irodalomban találunk a fair play magatartás mérésével foglalkozó tanulmányokat. Ezen tanulmányok jellemzően egy-egy fair play program köré épülnek, melyek azt hivatottak bizonyítani a programok kidolgozása és végrehajtása révén, hogy a sportszerú magatartás tanulható és tanítható.

Jelen tanulmány célja megvizsgálni és bemutatni, hogy a Kárpát-medencei fiatalok mit gondolnak a fogalomról. Milyen jelentéstartalmat tulajdonítanak a fair play-nek, illetve különböző versenyszituációkban hogyan reagálnának?

Vizsgálati módszerként egy kérdőíves vizsgálatot végeztünk, melynek mintavételi eljárása véletlen kiválasztáson alapult, három felsőoktatási intézmény 145 hallgatója töltötte ki a kérdőívet. A kitöltők között voltak romániai, ukrajnai magyar és magyarországi fiatalok.

A kérdőív 17 kérdést tartalmaz, melyből 15 zárt és kettő nyitott kérdés. A kérdések kiterjedtek a fair play jelentéstartalmára, a sport iránti érdeklődésre, ezenkívül a különböző versenyszituációkban történő reagálások, cselekedetek megítélésére is. Jelen tanulmányunk négy, a fair play, a sportszerű viselkedés megítélésére, értékelésére terjed ki.

Eredményként elmondható, hogy a három ország megkérdezett fiataljai a fair play fogalmához pozitív jelzőket kapcsolnak, és a különböző versenyszituációkban sportszerú magatartásformát tanúsítanak.
\end{abstract}

\section{Bevezetés}

A mai modern és rohanó világban, ahol a modern telekommunikációs eszközöknek köszönhetően minden percben elérhetőek/online vagyunk, bizonyos fogalmak, eredmények és értékrendek átértékelődnek. Ez a változás, mely értékvesztéssel is jár, jelen van az élet minden területén, ebből adódóan érzékelhető, hogy a XXI. századra a sport és a sporteredmények is új dimenzióba kerültek. Egy-egy sportág jelenét és jövőjét egyre inkább az határozza meg, hogy mennyire eladható, mennyire közvetíthető, mennyire tud alkalmazkodni a „szórakoztatóipar” elvárásaihoz. Mindemellett gazdasági és üzleti iparággá nőtte ki magát (sportruházat, sportszer, média stb.). 
Eredeti értékei (becsületesség, a szabályok mentén és megtartásával zajló küzdelem, a tisztelet és önzetlenség stb.) egyre inkább elhomályosodnak, elveszni látszanak. A győzelem és a pénz összekapcsolódott, a pénzért való harc sző át mindent, maga után vonja a sportszerütlen eszközök (csalás, bunda) alkalmazásának elterjedését, amely nem csupán a sportolók magatartásában nyilvánul meg (dopping).

Ha ez a tendencia tovább folytatódik, ha egyre inkább elfogadottabbá és nyíltabbá válik, visszafordíthatatlan károkat okoz egyrészt magában a sportban, amely így elveszíti eredeti értékeit, másrészt a felnövekvő generáció erkölcsi felfogásában.

Így jutunk el a mai valóságba, ahol bekapcsolva a televíziót, rádiót vagy internetes hírportálokat, tömegével halljuk, látjuk a híreket, miszerint a fiatalok (akár már tizenévesek is) tanárt vernek, játékból embereket ütnek le az utcán, ${ }^{1}$ ső́t ha ez nem lenne elég, egymást is megverik, kínozzák vagy megölik. Mindez nem Magyarországon egyedi, globális tendencia, fejlett európai és tengerentúli országokban is egyre gyakoribb. Éles váltás ez ahhoz képest, amikor a gyerekek az iskolában összekaptak, legfeljebb csúfolódtak (kiöltötték egymásra a nyelvüket) és néha összeverekedtek, de hamar ki is békültek.

Ma már gyakori az is, hogy az iskolában bántalmazzák azt a pedagógust, aki rendre utasítja a tiszteletlen diákot. A kérdés, azt gondoljuk, jogos: milyen felnőttek és milyen szülők lesznek az olyan gyerekekből, akik ilyen megoldási mintákat kapnak családi környezetükből a konfliktusok rendezésére?

Meddig terjed a közoktatás, az iskolarendszer és a pedagógus szerepe, felelőssége, kötelezettsége? Hol van az a pont, ahol meg lehet fordítani ezt a folyamatot, aminek következménye az erkölcsi értékvesztés? Milyen eszközrendszer, milyen lehetőségek állnak rendelkezésre, vannak-e hatékony megoldások, megfelelő módszerek?

Mivel több mint tíz évet töltöttem el a sportban, és tanulmányaim során meg is tapasztaltam a sportolás felemeló erejét, ha a fiatalokat a sporttevékenység felé irányítjuk, a szakemberek pedig tapasztalataikon keresztül a sport nevelési értéktöbbletét a fair play-t szem előtt tartják, akkor javulás várható. Előnye továbbá az is, hogy a sportban megszerzett értékek, megtanult magatartásformák az élet minden területére transzferálhatók.

A fair play szellemében történő nevelés a sport minden szintjén feladat, de különösen fontos az iskoláskorúak és leendő edzők, testnevelők, tanárok képzése során. Vizsgálatunk középpontjában felsőoktatási intézményekben tanuló hallgatók és véleményük, értékítéletük áll. Jelen tanulmányban elsősorban a hazai és a nemzetközi irodalomban megtalálható, a fair play fogalmához kapcsolódó tanulmányokat, illetve fair play programok eredményeit kívánjuk feltárni, és bemutatni saját kérdôíves vizsgálatunk eredményeit.

1 A ,játék” Amerikából indult világhódító útjára és mára Angliában és más európai országban is hódít. A lényege abban rejlik, hogy a fiatal a gyanútlan járókelő háta mögé lopakodik, és jól irányzott erős ütéssel leüti. Válogatás nélkül szedik az áldozatokat. Mindeközben a barátok a jelenetet rögzítik, és különböző internetes oldalakra feltöltik. Aki a legtöbb embert tudja leütni, az kapja a legnagyobb elismerést a világhálón. Ezek a fiatalok azzal sem törődnek, hogy az ütés következtében eszméletüket vesztő emberek meg is halhatnak. 
Szent-Györgyi Albert Nobel-díjas magyar orvos, biokémikus egyik parlamenti beszédében rendkívül jól összefoglalja a sport és a társadalom közötti kapcsolat lényegét. „Egy sportcsapat a társadalomnak kicsinyített képe, a mérkőzés az életért való nemes küzdelem szimbóluma. Itt a játék alatt tanítja meg a sport az embert rövid idó alatt a legfontosabb polgári erényekre: az összetartásra, az önfeláldozásra, az önálló megítélésre, az abszolút tisztességre és mindenekelőtt a »fair play«, a nemes küzdelem szabályaira."

\section{Elméleti háttér}

Fair play, neked mit jelent? A kérdés munkánk központi eleme, így nem mehetünk el mellette anélkül, hogy kísérletet ne tegyünk a fogalom meghatározására, tesszük mindezt természetesen a rendelkezésre álló szakirodalom alapján. Szeretnénk azonban leszögezni azt a tényt, habár a világ minden táján (legalábbis élünk ezzel a feltételezéssel) ismerik a fogalmat, egységes, mindenki által elfogadott meghatározás nincs rá, így mi is csak szemezgetünk és összevetünk.

A fair play fogalma az ICSPE (International Council of Sport and Physical Education) által 1964-ben rögzített Sportkiáltvány (Declaration on Sport), majd az 1974ben elfogadott Fair Play Charta által ,intézményesült" a sportéletben. A kiáltvány előszavában Philip Noel Baker az ICSPE Nobel-békedíjas akkori elnöke, többek között a következőket írja: „A fair play elve pedig valamennyi sportverseny lényege, ugyancsak alapvető jelentősége van mind a hivatásos, mind az amatőr sportban. Nemcsak a szabályok szigorú tiszteletben tartását követeli meg, hanem belsőjük és szellemük örömteli és spontán fogadását is. Ez a fogalom tartalmazza mind az ellenfél, mind a saját magunk tiszteletben tartását. A fair play elve nélkül a sportverseny megalázóvá és lealacsonyítóvá válhatna az abban résztvevő́k számára. Ha a galád praktikák, amelyek sajnos még ma is sokszor előfordulnak a nemzetközi és világversenyeken, tovább terjednének, a sport mint nevelő eszköz, mint a kikapcsolódás és a csoportos szórakozás formája, mint a népek közötti megegyezés tényezője visszavonhatatlanul elveszítené értékét" (Baker 1964: 5-6).

Az Európa Tanács által kiadott Sport Etikai Kódex (2001: 19-20) a fair play fogalmát a következőképpen fogalmazza meg: „A fair play többet jelen a szabályok betartásánál. Magában foglalja a barátság eszméjét, mások tiszteletben tartását, valamint a megfelelô szellembe történő játékot. A fair play gondolkodásmódot jelent, nem csupán viselkedési formát."

Hogan (1973) a fair play fogalmát összekapcsolja az erkölccsel és a társadalmi értékekkel, melyek a sportban kiemelt jelentőséggel jelennek meg. Ebből következik, hogy a sportolók viselkedését és az erkölcsi tartásukat a sportban tanult normák, sportszabályok határozzák meg. Hofmann (1990) továbbmegy, feltételezi, hogy az empátia szoros kapcsolatban van a legtöbb erkölcsi elvvel, ezáltal hatással van az erkölcsi ítélkezésre és következtetésre, így a testnevelés során elnyert empatikus készségek meghatározóak lehetnek a fair play viselkedés kialakításában. 
A kérdés csupán az, hogy minden esetben a fair play szellemiségének megfelelő normák tudatosulnak a fiatalokban, sportolókban vagy a cél (jelen esetben a győzelem) szentesíti az eszközt? Zsolt (1983) szerint, aki sportszerú, az bemutatja az írott és íratlan erkölcsi szabályokat, normákat, nem csap be senkit, nem alkalmaz tisztességtelen eszközöket másokkal szemben.

Keating (1995: 147) megfogalmazása szerint „a fair play egyfajta morális kód, mely végigvezeti a magatartást a sportban". Tehát a fair play kifejezés alatt egy sor szociomorális értéket érthetünk, melyek a sporton keresztül kerülnek átadásra.

Vallerand, Briere, Blanchard és Provencher (1997) meghatározása szerint a sportszerűség úgy definiálható, mint a szabályok, bírók, társadalmi normák és az ellenfél tisztelete, valamint a sportág iránti elkötelezettség, és a sportban való részvétellel kapcsolatos negatív viselkedésformák viszonylagos hiánya. A fair play kifejezés magában foglal több társadalmi és morális értéket, melyek alkalmazhatóak a sportra és a testnevelésre. Olyan alapelveket foglal magába, mint, hogy:

- tiszteletben kell tartani a játékszabályokat, valamint a különböző bajnokságok, tornák szabályzatát;

- minden erőfeszítést meg kell tenni az ellenféllel, a játékvezetókkel és a mérkőzésen résztvevő minden más személlyel/nézőkkel, csapatvezetőkkel, a médiák képviselőivel/szembeni sportszerú magatartás érdekében.

A mérkőzés minden részt vevőjét ösztönözni kell, hogy e viselkedési szabályokat betartsa, ennek megfelelő magatartást tanúsítson a mérkőzés előtt, alatt és után, bármi legyen is a mérkőzés eredménye és a játékvezető döntése.

A fair play Butcher és Schneider (1998: 1) szerint ,az a nézet, melyet sportnak használnia kellene annak érdekében, hogy megtanítsa a pozitív társadalmi értékeket...” A fair play „az általános erkölcsi vagy társadalmi értékek egy része, melyet a sporton és fizikai tevékenységen keresztül tanítanak".

Horváth és Prisztóka (2005) korábbra nyúl vissza, szerintük a fair play eszméje az ókori görög társadalom emberideáljában gyökerezik, amely a vitézséget, bátorságot, férfiasságot, becsületet, erényt mint életelveket fogalmazott meg és becsült nagyra. Az ókori olimpiákon a szabályok megszegése komoly szankciókat vont maga után. Manapság a modern gondolkodók szerint a felgyorsult világ, a minél nagyobb teljesítmények elérésének hajszolása, a pénz utáni mérhetetlen vágy felülír szinte mindent, és így a fair play is idealisztikussá válik az általa képviselt értékekkel együtt.

Összességében elmondható, hogy a fair play fogalmi meghatározása egy igen széles skálán mozog, de van közös pont a megfogalmazásokban. A fogalom a sportból ered, de nemcsak egy fogalom, mely szoros kapcsolatban, összefüggésben van az erkölccsel, empátiával, sportszerűséggel, mások tiszteletben tartásával, hanem egy filozófiaként is felfogható. Mára az élet minden területén jelen van a fair play fogalma és szellemisége. 


\section{Kutatási előzmények}

A nemzetközi szakirodalomban fellelhető fair play-hez kapcsolódó kutatások két nagy csoportra oszthatók. Egyrészt kidolgoztak egy-egy fair play programot, melyben különböző korosztályokat, sportolókat és nem sportolókat vizsgáltak. Mérték a fair play-hez való hozzáállásukat a program elején és végén. A másik csoportba azok a kutatások tartoznak, melyben erkölcsi ítélethozatali képességet és annak fejlődését mérték a sport által szintén különböző korosztályban, sportolókon és nem sportolókon. A korábban leírtak értelmében az erkölcsi magatartás befolyásolja a sportszerüséget is. Mindegyik esetben abból a nézetből indultak ki a szerzők, hogy a sport pozitív irányba befolyásolja a jellemet, valamint meghatározó szerepe van az erkölcsi fejlődésben, ezáltal sportszerủ magatartást alakít ki.

Az első, általunk szakirodalomban fellelt fair play kutatás Hall (1986) nevéhez fúződik, aki az erkölcsi/morális érvelés és ítélethozatal szintjét mérte. 65 egyetemi kosárlabdázóval végzett vizsgálatot, kontrollcsoportként pedig nem sportoló főiskolai hallgatókat választott. Eredményként megállapította, hogy a sportolók alacsonyabb pontszámot értek el, mint nem sportoló társaik.

Bredemeier és Shields (1986) 30 kosárlabda-játékos férfi és nő morális érvelését vizsgálta szemben 10 nem sportoló egyénnel. Az eredmény változatlanul azt mutatta, amit Hallnál is, hogy a sportolók jelentősen alacsonyabb pontszámot értek el a teszteken. Egy követéses vizsgálattal egészítették ki eredményeiket, mikor is 20 úszót vontak be a mintába, és arra a következtetésre jutottak, hogy nincs különbség a morális érvelés fejlettségében az úszók és a nem sportolók között.

Később Stevenson (1998) nagyobb mintán végzett vizsgálatot, 213 élsportoló és 202 nem sportoló diákot mért. Az élsportolókat két csoportra osztotta, csapatsportolókra és egyéni sportolókra. Az eredményekből kiderül, a nagyobb mintán elvégzett kutatás eredménye is megegyezik Hall és Bredemeier, illetve Shields (1984) eredményeivel, tehát a legalacsonyabb pontszámot az erkölcsi ítélethozatali mérésben a csapatsportban sportolók produkálták. Ezen eredményekre Rulmyr (1996), aki középiskolásokat mért, valamint Proios és munkatársai (2004) rácáfoltak vizsgálatukban: nem találtak különbséget a sportoló és nem sportoló fiatalok morális érvelési érettségében.

Összességében a vizsgálatok eredményei éppúgy bizonyítják, hogy a csapatsportban sportolók erkölcsi fejlődése messze elmarad az egyéni sportolókétól és a nem sportolókétól, mint annak ellenkezőjét. Priest, Krause és Beach (1999) felhívják a figyelmet arra, hogy a mérésekben egyetemi csapatsportolók vettek részt, és számos egyéb befolyásoló tényezővel nem számoltak a kutatók, ilyen például, hogy milyen tanulmányi átlaggal kerültek be a felsőoktatási intézményekbe a sportoló hallgatók. De azt gondoljuk, érdemes lenne tisztázni azt is, milyen sportolói múlttal rendelkeznek pontosan, milyen instrukciókat kapnak edzőiktől, ezenkívül a demográfiai adatok sem tisztázottak. Fontos továbbá azt is megjegyezni, hogy ezek a mintavételi eljárások nem voltak egységesítve. Mindettől függetlenül a tanulmányok eredményei arra engednek következtetni, hogy bizonyos sportokban részt vevő fiatalok egyetemi szinten talán alacso- 
nyabb erkölcsi érvelési szinten állnak társaikhoz képest. Megállapítható továbbá, hogy nem lehet minden sportágat egy kalap alá venni, megvan a saját szabály- és normarendszerük, de elmondható, hogy általánosan elismert sporterkölcsi értékek vannak.

A tanulmányok második csoportja a fair play témakörében egy-egy konkrét program köré épültek. A Hassandra, Goudas, Hatzigeorgiadis és Theodorakis (2007) által végzett kutatás eredményei igen kecsegtetóek. A vizsgálat célja volt egy, a fair play elveit hirdető intervenciós program eredményességének felmérése olyan iskolákban, ahol az utánpótláskorú fiatalok tanulnak. Négy általános iskolából 126 ötödik osztályos diák vett részt a kutatásban, 66 a kísérleti csoportban, 60 pedig a kontrollcsoportban. Az eredmények mind a négy vizsgált dimenzióban jelentős javulást mutattak, így a megfigyelt fair play magatartásban, az osztálytermi támogatásban és autonómiában, a játékhoz való hozzáállásban és a kísérleti csoport belső motivációja terén is. A követéses vizsgálat eredményei megmutatták, hogy az elért eredmények a program vége után még két hónapig megmaradtak. Általánosságban elmondható, hogy a fair play intervenció azonnali és hosszabb távú hatással is volt a diákokra (Hassandra et al.2007).

Sezen-Balcikanli (2009) a Gazi Egyetem hallgatói körében végzett kutatást. Ennek keretében a „Fair play a sportban és az oktatásban” címú kurzust hirdették meg. A vizsgálatban 50 hallgató, nők és férfiak vegyesen, vettek részt 14 héten keresztül. A tanórai foglalkozások alkalmával számos, a fair play témájához kapcsolódó előadáson vettek részt. Tudnunk kell azt is, hogy a hallgatók tanár szakos diákok voltak. A 14. hét végére az eredményeik szerint, ahogy Hassandra és munkatársainak esetében is, pozitívak voltak. Komoly és mérhető fejlődést értek el az empátiakészség, ezáltal a fair play-hez való hozzáállásban, mely készségek a gyakorlatban is megvalósultak.

A kutatás fontosságát adja az a megállapítás is, melyet Bredemeier és Shields (2006) tettek. Eszerint testnevelési környezetben a fair play magatartás fejleszthető, de az élsportban a sportolók viselkedését az edzőktôl kapott instrukciók nagyban befolyásolják, sok esetben negatív irányban. Ezért a Hassandra és munkatársai által végzett kutatás eredményei pozitívnak tekinthetők, hisz a következő tanár és edző generáción végeztek vizsgálatot.

Mindezek után felmerül a kérdés, hogy a versenysport/élsport „rontja-e el” a fiatalokat azáltal, hogy a győzelem megszerzését mindennél fontosabbnak tartja.

A fair play magatartás vizsgálatához szorosan nem kapcsolódik, a sport nevelő és jellemfejlesztő hatásához azonban igen, Kovács (2014) kutatása, melyben sportoló felnőttekkel végzett mélyinterjús vizsgálatot. Eredményként megállapította, sportolás közben legtöbbször észrevétlenül is fejlődik az egyén. Ez a fejlődés nemcsak pszichikai vagy fizikai fejlődés jelent, hanem jellembeli fejlődést is. 


\section{Hipotézisek}

Egy társadalomban uralkodó norma- és értékrend meghatározza a társadalom tagjainak erkölcsi felfogását, mely a fair play fogalmához való viszonyra is kihatással van. Ezáltal feltételezzük, hogy függetlenül attól, hogy milyen társadalmi, gazdasági, illetve szociokulturális környezetben élnek diákok azonos értékítélettel rendelkeznek, és azonos jelentéstartalmat tulajdonítanak a fair play-nek.

Továbbá feltételezzük, hogy az egyetemista korosztály a különböző versenyszituációkban sportszerúen cselekedne, még úgy is, hogy ezzel a csapata győzelmét veszélyezteti.

\section{Vizsgálati módszer}

Mint azt korábban már említettük, egyre népszerúbb téma a fair play, így a nemzetközi irodalomban találunk ennek mérésére alkalmas programokat és tanulmányokat. Mindeközben felmerülhet a kérdés: miért vált központi témává ez a terület? Talán azért, mert egyre érezhetőbb a társadalmakban lévő erkölcs- és értékvesztés? De ha szinte minden nap, minden helyzetben, mindenki ,fair”, nem fog a fogalom kiürülni, nem fog egy új, esetleg torz jelentéstartalmat kapni? Hol tartunk most ebben a folyamatban? Ezt kívánjuk mérni a kérdőíves vizsgálatunkkal. Jelen tanulmányban egyetemistákat kérdeztünk a fogalomról, illetve az ehhez kapcsolódó viselkedési formákról.

Vizsgálati módszerként egy kérdőíves vizsgálatot végeztünk, melynek mintavételi eljárása véletlen kiválasztáson alapult, három felsőoktatási intézmény 145 hallgatója töltötte ki a kérdőívet. A kitöltók között voltak romániai magyar (44fó), ukrajnai magyar (25 fó) és magyarországi (76 fó) fiatalok. A megkérdezett hallgatók bölcsészettudományi, természettudományi, jogtudományi, közgazdaság-tudományi képzésben vesznek részt. A nemek szerinti eloszlást tekintve 45 fő férfi és 100 fő női hallgató szerepelt a mintában. A megkérdezés és adatgyüjtés online kérdôív segítségével történt. A kérdőív 17 kérdést tartalmaz, melyből 15 zárt és kettő nyilt végú kérdés. Tanulmányunk terjedelmi kereteit figyelembe véve négy kérdés eredményeit mutatjuk be jelen tanulmányunkban. A kérdések kiterjedtek a fair play jelentéstartalmára, a sport iránti érdeklódésre, ezenkívül a különböző versenyszituációkban történő reagálások, cselekedetek megítélésére is.

\section{Eredmények}

Az első kérdéskörben azt kívántuk vizsgálni, hogy a hallgatók milyen magatartást tanúsítanának különböző versenyszituációban ellenfelükkel, saját csapattársaikkal, illetve a játékvezetővel szemben.

Az első kérdésünkre adott válaszokból, miszerint „Ellenfeled sérülése esetén mit tennél?” (1. ábra), kiderül, hogy a fiatalok jelentős arányban a sportszerűséget figye- 
lembe véve cselekednének. A megkérdezett magyarországi diákok 61,8\%-a megállna, és akár átengedve az ellenfélnek a helyzetet, segítene sérült társának. Az ukrajnai magyar fiatalok 48, a romániai magyar fóiskolásoknak pedig 61,4\%-a cselekedne ugyanígy. Hasonlóan korrekt magatartás, ha a fiatalok szándékosan megállitják a játékot. Érdekesnek tartjuk, a magyarországi, illetve a romániai mintához képest kiugró eredménynek számít az a megkérdezett ukrajnai magyar hallgatóknak a 12\%-a, akik a helyzetet előnyszerzésre használnák fel. Egy esetleges mélyinterjú során ennek okára fényt lehetne deríteni.

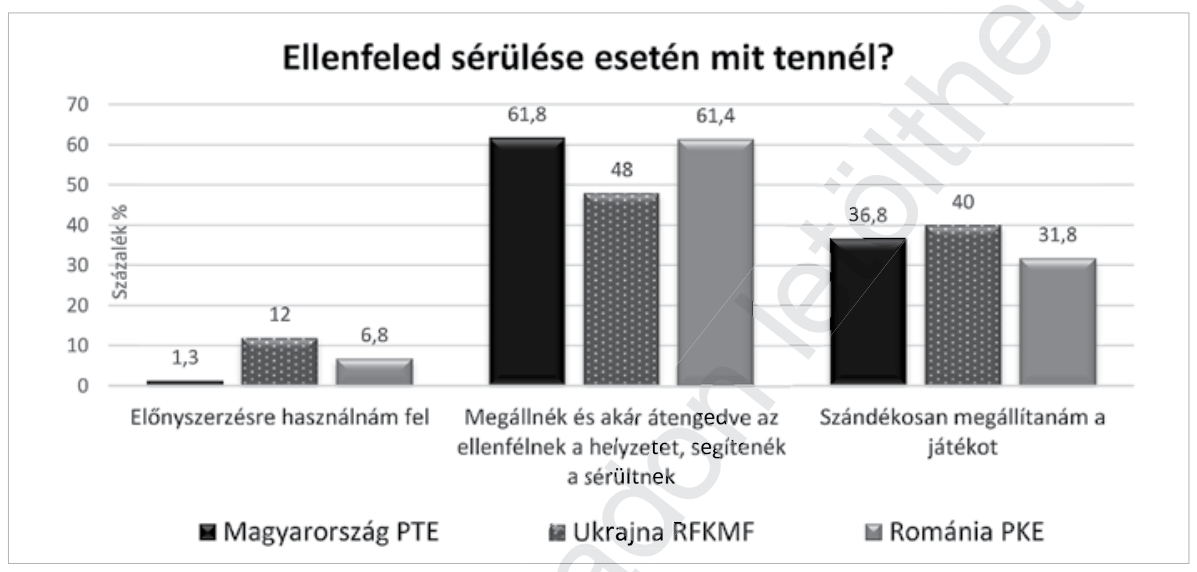

1. ábra. Sportszerú viselkedés mérése ellenfél játékos sérülése esetén $(\mathrm{N}=145)$.

Forrás: saját kutatás

Második kérdésünkben (2. ábra) arra voltunk kíváncsiak, hogy egy csapatjáték esetén mennyire érvényesül a csapatszellem és mennyire tudják a mai fiatalok felmérni, hogy önmaguk háttérbe szorításával talán nagyobb eredményt tudnak elérni. A megkérdezett hallgatók több mint fele országtól függetlenül önzetlenül átadná a labdát társának. Az nem derül ki a válaszokból, hogy azok, akik mérlegelnék a helyzetet végül, hogy cselekednének.

Ettôl eltekintve is vannak a magyarországi hallgatók között 1,3\%-ban, a romániai magyar fiatalok körében 6,8\%-ban, akik saját magukat hagynák érvényesülni. Az ukrajnai magyar diákok itt is a többiekhez képest kiugró értéket mutatnak a maguk 8\%-ával az önzőbb magatartási forma megjelenésében, de ki kell emelni azt is, hogy 52\%-uk habozás nélkül adná át a labdát saját társának. Visszautalnánk a szakirodalmi áttekintés azon eredményére, miszerint a csapatsportban sportolók erkölcsi érvelési szintje messze elmarad mind az egyéni sportolókétól, mind a nem sportoló fiatalokétól.

Igazán nagy különbség nincs a megkérdezett fiatalok viselkedésében azon vonatkozásban, hogy ellenfelükkel szemben vagy csapattársaikkal szemben kívánatos sportszerúen cselekedni. Összességében ez mindenképp pozitív eredmény, mert ebből kiderülhet, hogy a fair play magatartás nem válogat ellenfél vagy csapattárs között. 


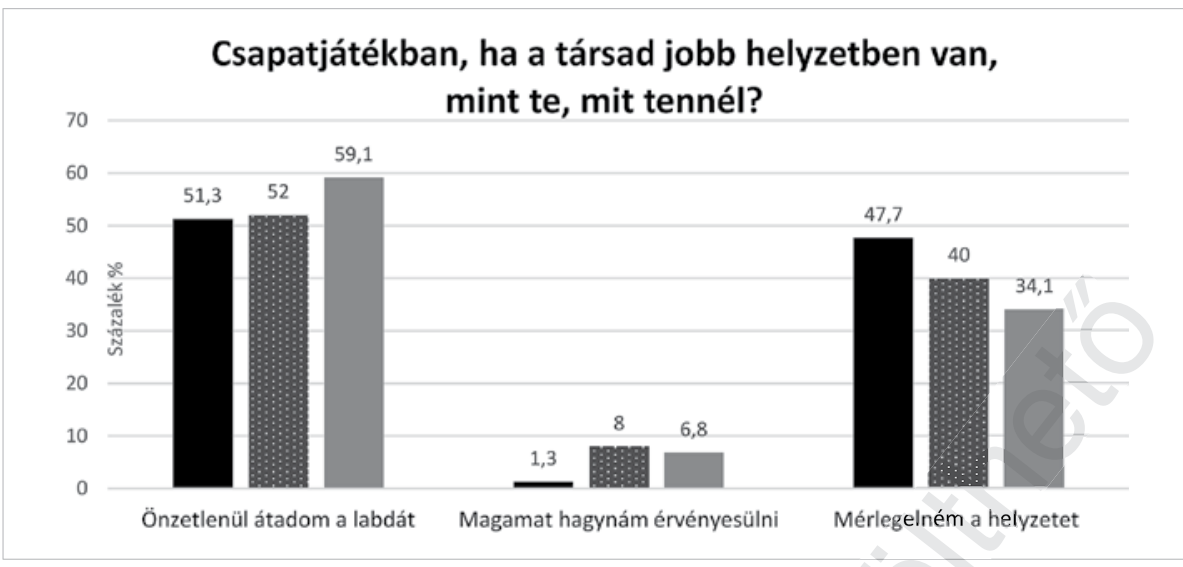

2. ábra. Versenyhelyzet és a csapatszellem megjelenése $(\mathrm{N}=145)$.

Forrás: saját kutatás

A harmadik kérdés (3. ábra) eredményeinek bemutatása előtt ki kell emelnünk, hogy mind a 145 megkérdezett hallgató szerint van korrupció a sportban, ezek függvényében talán érthetőbbek a kérdésünkre adott válaszok. Egy, a játékvezető által tévesen megítélt helyzetben (talán pontosan a csalás és korrupció, bunda lehetőségéből kiindulva) a magyarországi hallgatók 64,5, az ukrajnai magyar diákok 72 és a romániai magyar fiatalok 72,7\%-a nem tudná a döntést elviselni, és képes lenne a játékvezetővel vitatkozni is. Érdekes kérdés lehet, hogy ebben az esetben a fiatalok a vitából eredő szankciókkal (sárga lap, kiállítás) is tisztában vannak-e, és megéri-e nekik ilyen következmények esetén is kiállni igazukért. Ezt a választási lehetőséget a következményeivel együtt éppúgy „veszélyesnek” tartjuk, mint azt, ha az ellenfél játékosán vesznek elégtételt.

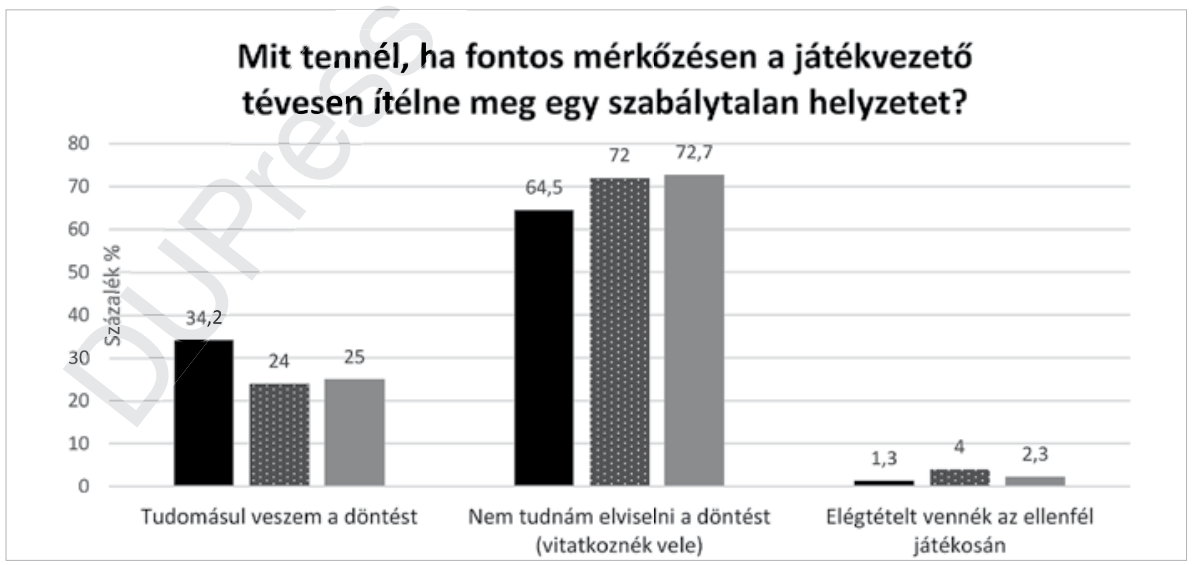

3. ábra. Versenyhelyzet és a csapatszellem megjelenése $(\mathrm{N}=145)$.

Forrás: saját kutatás 
Vizsgálatunk középpontjában a fair play jelentéstartalmának vizsgálata áll, így elkerülhetetlen tisztázni, a megkérdezett 145 hallgató milyen jelentéstartalmat tulajdonít a fogalomnak azok után, hogy láttuk a különböző versenyszituációkban hogyan cselekednének.

A kérdés némi magyarázatra szorul, ugyanis a fiataloknak 10 lehetőségből a számukra három legfontosabbat kellett megjelölniük. A válaszok között voltak pozitív és negatív opciók is, ezek voltak az erkölcsösség, a másik fél tiszteletben tartása, igazságosság, méltóság, barátság, becsületesség, korrupció, csalás, dopping, erőszak.

A 4. ábrán látható eredmények alapján elmondható, hogy a magyarországi, romániai és ukrajnai hallgatók is az első három helyen ugyanazokat az opciókat választották, tehát a fair play fogalmához olyan pozitív jelentéstartalmat párosítanak, mint a másik fél tiszteletben tartása, igazságosság és becsületesség. Megállapítható, hogy a negatív jelentéstartalom közül az eredmények közé egyedül a korrupció került be nem egészen $1 \%$-kal.

1. táblázat. A fair play jelentéstartalma $(\mathrm{N}=145)$

\begin{tabular}{|l|c|c|c|}
\hline \multicolumn{5}{|c|}{ Mit jelent neked a fair play? } \\
\hline & Magyarország PTE & Ukrajna RFKMF & Románia PKE \\
\hline Erkölcsösség & 10,5 & 4 & 9,09 \\
\hline Csalás & 0 & 0 & 0 \\
\hline A másik fél tiszteletben tartása & $\mathbf{2 8 , 9}$ & $\mathbf{2 9}$ & $\mathbf{2 5 , 7}$ \\
\hline Igazságosság & $\mathbf{2 0 , 6}$ & $\mathbf{2 1}$ & $\mathbf{1 9 , 6}$ \\
\hline Méltóság & 7,03 & 5 & 7,5 \\
\hline Korrupció & 0 & 0 & 0,7 \\
\hline Barátság & 3,06 & 8 & 3,8 \\
\hline Becsületesség & $\mathbf{2 9 , 8}$ & 31 & 32,5 \\
\hline Dopping & 0 & 0 & 0 \\
\hline Erőszak & 0 & 0 & 0 \\
\hline
\end{tabular}

Forrás: saját kutatás

\section{Következtetések}

Korábbi kutatások a fair play fogalmát és a fair play magatartást összefüggésbe hozták a sporttal, az erkölcsi érzet fejlettségével, az empátiával. Vizsgálták annak lehetőségét, hogy a sport által megtanult pozitív értékek milyen magatartásformákban nyilvánulnak meg az élet minden területén.

A kutatások viszonylag széles skálán mozognak ebben a témakörben. A vizsgálatunk Magyarországon egyedinek mondható, mert nem egy programon keresztül vizsgálta a fiatalok különböző csoportját, sokkal inkább arra voltunk kíváncsiak, hogy 
milyen jelentéstartalmat tulajdonítanak a fogalomnak, és a különböző versenyhelyzetekben hogyan cselekednének.

Az általunk bemutatott eredmények alapján elmondható, hogy első hipotézisünk igazolódott, eszerint függetlenül attól, hogy milyen társadalmi, gazdasági, illetve szociokulturális környezetben élnek diákok, azonos értékítélettel rendelkeznek, és azonos jelentéstartalmat tulajdonítanak a fair play-nek.

Második hipotézisünk, hogy az egyetemista korosztály a különböző versenyszituációkban sportszerúen cselekedne, még úgy is, hogy ezzel a csapata győzelmét veszélyezteti, szintén igazolást nyert. A három ország megkérdezett fiataljai sportszerúen viselkednének a legnagyobb versenyhelyzetben is, függetlenül attól, hogy a saját csapattársukról vagy az ellenfélről van szó.

Mind a fentebb említett kutatások, mind a mi eddigi és az itt bemutatott eredményeink pozitív képet adnak a sport nevelő és értékteremtő hatásáról, az érezhető társadalmi erkölcs- és értékvesztés folyamata még visszafordítható. Ehhez elkötelezett pedagógusok szükségesek, akik a szülőkkel karöltve támogatják a felnövekvő generációt. De nem hagyhatjuk figyelmen kívül azokat a nézeteket sem, melyek szerint a sport antiszociális magatartásformákhoz is vezethet.

Későbbi vizsgálat tárgya lehet egyrészt a sport szerepének pozitív és negatív hatásainak szélesebb vizsgálata, a kérdőív kérdéskörének kiterjesztése, a minta bővítése és egy gyakorlatban lefolytatott program általi mérés is.

\section{Hivatkozott irodalom}

- Baker, P. N. (1964). International Council of Sport and Physical Education (ICSSPE) Declaration on Sport. Berlin, ICSSPE.

- Butcher, R. \& Schneider, A. (1998). Fair play as respect for the game. Journal of the Philosophy of Sport, (25), 1-22.

- Bredemeier, B. \& Shields, D. (1984). Divergence in moral reasoning about sport and life. Sociology of Sport Journal, 1, 348-357.

- Bredemeier, B. \& Shields, D. (1986). Moral growth among athletes and nonathletes: A comparative analysis. Journal of Genetic Psychology, (147), 7-18.

- Bredemeier, L. B. \& Shields, L. D. (2006). Sport and character development. Research Digest, 7, 1.

- Europa Tanács Információs és Dokumentációs Központ (2001). Európai Sport Charta és a Sport Etikai Kódex.

- Hall, E. R. (1986). Moral development levels of athletes in sport-specific and general social situations. In Vander Velden, L. \& Humphrey, J. H. (eds.): Psychology and sociology of sport: Current selected research (pp. 191-204). New York, AMS Press.

- Hassandra, M., Goudas, M., Hatzigeorgiadis, A. \& Theodorakis, Y. (2007). A fair play intervention program in school Olympic education. European Journal of Psychology of Education, 13 (2), 99-114. 
- Hoffman,M.L.(1990). The contribution of empathy to justice and moral judgment. In Esinberg, N. \& Strayer, J. (eds.): Empathy and its development (pp. 47-80). New York, Cambridge University Press.

- Hogan, R. (1973). Moral conduct and moral character: A psychological perspective. Psychological Bulletin, 79, 217-232.

- Horváth L. \& Prisztóka Gy. (2005). A sportpedagógia és sportpszichológia alapkérdései. Nyíregyháza, Bessenyei György Könyvkiadó.

- Keating, J.W. (1995). Sportmanship as a moral category. Ethics, 75, 147.

- Kovács K. (2014). A sportolás, mint a tanulás és nevelés színtere. In Juhász E. (szerk.): Tanuló közösségek, közösségi tanulás. A tanuló régió kutatás új eredményei (pp. 213-236). Debrecen, CHERD-H.

- Priest, R. G., Krause, J. V. \& Beach, J. (1999). Four-year changes in college athletes = ethical value choices in sports situations. Research Quarterly for Exercise and Sport, (70), 170-178.

- Proios, M., Doganis, G. \& Athanailidis, I. (2004). Moral development and form of participation, type of sport, and sport experience. Perceptual \& Motor Skills, (99), 633-642.

- Rulmyr, R. (1996). Interscholastic athletic participation and the moral development of adolescents in Arizona high schools. Unpublished doctoral dissertation. San Francisco, Northern Arizona University.

- Sezen-Balcikanli, G. (2009). Fair play and empathy: A research study with student teachers. Journal of US - China Public Administration, 6 (4), 79-84.

- Stevenson, M. J. (1998). Measuring the cognitive moral reasoning of collegiate studentathletes: The development of the Stevenson-Stoll Social Responsibility Questionnaire. Unpublished doctoral dissertation. Moscow, University of Idaho.

- Zsolt R. (1983). Sportolók, sporterkölcsök. Budapest, Sport.

- Vallerand, R., Briere, N., Blanchard, C. \& Provencher, P. (1997). Development and validation of the Multidimensional Sportpersonship Orientation Scale. Journal of Sport and Exercise Psychology, 19 (2), 197-206. 


\title{
Nagy Beáta Erika, Kovács Karolina Eszter
}

\section{Serdülők egészségmagatartása a sport és családszerkezet függvényében}

\begin{abstract}
Absztrakt
Az egészségtudatosság fontos szerepet játszik életünkben. Fontos, hogy megfelelő életvitelt éljünk, hiszen a helyes életmód segít az optimális egészségi állapot megőrzésében és a krónikus betegségek megelőzésében (Conner 2005). A család és a szülők szerepe serdülőkorban még mindig jelentős, hiszen - bár a gyerekek egyre inkább kortársaik felé fordulnak - a család mintegy támogató bázisként jelen van a serdülő életében (Kovács \& Pikó 2009). Ez azonban a családszerkezet válságával és megbomlásával nem tud teljesülni, ami komoly stresszforrást jelent a gyermek számára, így növelheti az egészségkárosító magatartások megjelenését, azok kipróbálását, súlyosabb esetben hosszú távú fennmaradását is (Bramlett \& Blumber 2007). A kutatás célja a dohányzás, a túlzott alkoholfogyasztás és a kemény drogok kipróbálásának feltérképezése a sportolás, valamint a családszerkezet függvényében három kelet-magyarországi megye területén a FASCES $2015^{1}$ kutatás alapján. Az eredmények alapján a sportolás önmagában nem befolyásolja a kipróbálási arányt, bár tendenciaszinten protektív faktorként jelenik meg. Önmagában a családszerkezet sem szignifikáns hatótényező, ugyanakkor a társadalmi háttérváltozók közvetítőszerepe jól érezhető a dohányzás, alkoholfogyasztás és füves cigaretta esetében.
\end{abstract}

\section{Bevezetés}

A serdülőkor az egészségkárosító magatartásformák gyakoriságának tekintetében a legmagasabb kockázattal járó időszak, ugyanis ebben az életkorban az egészségkárosító magatartások gyakorisága nő, miközben az egészségvédő magatartásformák aránya csökken (Lohaus et al. 2009). A serdülőkori rizikóviselkedések, például alkohol- és drogfogyasztás, dohányzás vagy promiszkuitás (szexuális partnerek gyakori váltogatása) közös jellemzője, hogy ezeket a fiatal felnőttesnek ítéli meg, emiatt válnak vonzóvá számára.

Bizonyos kockázatvállaló és egészségkárosító magatartás rövid távon pozitívan hathat a személy számára, hiszen akár az alkohol- vagy drogfogyasztás, akár a dohányzás is megnyugtató hatással bírhat, átmenetileg csökkenti a szorongást és kellemes hangu-

${ }^{1}$ Family Structural Crisis Effect on School Effectiveness Survey 2015 (Család strukturális válságának hatása az iskolai eredményességre 2015), $\mathrm{N}=627$. 
lattal jár együtt. Ez állhat a káros szenvedélyek magas aránya mögött, amely a serdülőkorban is igen nagy motivátor lehet. A káros hatások alapvetően csak hosszú távon jelentkeznek. Így a kockázatvállalás egyik szempontja a mérlegelés, hogy megéri-e a rövid távú élvezet, vagyis az egészségtudatosság a jövőorientációval is kapcsolatban áll (Rothspan \& Read 1996). Ebben az életkorban azonban általában az aktuális előnyök választása jellemző, a hosszú távú egészségelőny figyelmen kívül hagyásával (Goldberg et al. 2002). Másrészt a kipróbálás nem feltétlenül maladaptív serdülőkorban, hiszen az egészségkárosító magatartás a pszichoszociális fejlődés egyik erőforrása is lehet, amely egészségmegőrző funkciót tölt be: kortárscsoportba való integrálódás, autoritással szembeni lázadás, feszültségoldás, hiánypótlás vagy kompenzálás (Brassai 2010). Vagyis ebben az értelemben pszichológiai szempontból nem tekinthetô egyértelmúen károsnak, ha a serdülő megtapasztalja a rövid távú előnyöket. Problémát az jelent, ha az egészségkárosító magatartás hosszú távon is fennmarad.

A fiatalok egészségmagatartására irányuló kutatások eredményei évről évre aggasztóbbak: az élvezeti szerek használata és a rendszeres szexuális élet egyre fiatalabb korban kezdődik, és egyre szélesebb kört érint (Csizmadia \& Várnai 2003; Németh 2003; Sebestyén 2003), valamint a fiatalok körében kirívóan magas a pszichoszomatikus tünetek előfordulási aránya is (Susánszky \& Szántó 2002).

Az egészségkárosító magatartásformák közül az egyik legnagyobb veszélyforrásnak a dohányzás tekinthető, a hazai lakosság körében mégis igen magas a dohányzók aránya. A HBSC (Health Behaviour in School-aged Children, Iskoláskorú gyermekek egészségmagatartása) 2010-es eredményei alapján elmondható, hogy az életkor előrehaladtával egyre magasabb a cigaretta kipróbálási aránya. Már az 5. évfolyamon tanuló diákok 14,5\%-a vallotta azt, hogy kipróbálta a dohányzást, míg a 11. évfolyamon ez az arány már 76,8\%. A fiúkra minden korcsoportban nagyobb arányban jellemző a kipróbálási gyakoriság, azonban a gimnáziumban az arány csaknem kiegyenlítődik (Németh \& Költő 2011). Emellett a rendszeresen (legalább hetente) dohányzók aránya is egyre nő az életkor előrehaladtával. Az ötödikesek körében a fiúk 3,5\%-a és a lányok 1\%-a vallotta magáról, hogy rendszeresen dohányzik, míg a hetedikesek körében a fiúk 8,8\%-a és a lányok 6,7\%-a tartja magát rendszeres dohányosnak. Ezt követően ugrásszerú emelkedés tapasztalható, hiszen a kilencedikesek körében a fiúk 29,6\%-a és a lányok 26\%-a, míg a tizenegyedikesek körében a fiúk 41,5\%-a és a lányok 33,8\%-a tekinthetô rendszeresen dohányzónak (Németh \& Költő 2011).

A dohányzás mellett hazánkban az alkoholfogyasztás jelent súlyos problémát az egészségkárosító magatartásformák közül. A HBSC 2010-es eredményei alapján elmondható, hogy az alkohollal való találkozás gyakran igen korán megtörténik. Az 5 . osztályos gyerekek több mint 30\%-a fogyasztott már alkoholt: a fiúk 44\%-a, míg a lányok 30,5\%-a. Az életkor előrehaladtával egyre magasabbak a kipróbálási arányok. A 7. osztályos fiúk 68,5\%-a, a lányok 61,2\%-a fogyasztott már alkoholt. Az általános iskolában még szignifikáns különbség mutatható ki az alkohol kipróbálását illetően a fiúk és lányok között, ez a különbség azonban a középiskolában eltúnik. A 9. évfolyamos fiúk 86,3\%-a, a lányok 83,9\%-a vallotta magáról, hogy fogyasztott már alkoholt; 
a 11. évfolyamon pedig a fiúk 91,3\%-a és a lányok 90,6\%-a próbálta már ki. A fogyasztási gyakoriság tekintetében is elmondható, hogy az idősebbek körében szignifikánsan magasabb a fogyasztás aránya (Németh \& Költő 2011).

A káros szenvedélyek közül az illegális szerhasználatot szükséges még megemlíteni. Hazánkban a kábítószer-fogyasztással kapcsolatos eredmények is aggasztóak. A HBSC 2010-es vizsgálata során kimutatták, hogy a 9. és 11. osztályosok közel egyharmada fogyasztott már életében valamilyen illegális szert, gyógyszert visszaélésszerủen vagy valamilyen inhalánst. A fiúk körében magasabb a kipróbálási arány: a 9. évfolyamon a fiúk 29,7\%-a, a lányok 22,3\%-a próbált már ki legalább egyszer valamilyen kábítószert, a 11. évfolyamon pedig a fiúk 38,4\%-a, a lányoknak pedig a 31,2\%-a találkozott már legalább egyszer valamilyen illegális szerrel. A drogfogyasztás tekintetében a kannabisz egy-két alkalommal való kipróbálása mutatkozott a leggyakoribbnak (8\%), valamint a gyógyszerfogyasztás alkohollal (7,2\%) vagy önmagában $(3,4 \%)$, valamint az amfetaminok (speed) alkalmi használata $(4,7)$ mutatkozott a legnagyobbnak (Németh \& Költő 2011).

\section{Sport és kockázati magatartás}

A nyugati társadalmakban a rendszeres testmozgás mértéke alacsony, habár a sportolás pozitív hatásait a korábbi kutatások széles körben feltárták. Hallal et al. (2012, idézi Smith et al.2015) 122 ország bevonásával felnőttek (15 évnél idősebbek) körében végzett kutatásokat, melyek során megállapította, hogy körülbelül a felnőttek harmada $(31,1 \%)$ fizikailag inaktív. A magyar lakosság csaknem fele többnyire ül vagy áll munkája során (a munkahely mellett egyéb munkajellegú tevékenységek pl. házimunka, tanulás bevonásával). A lakosság csupán 4,5\%-a végez minden nap testmozgást, míg 67\%-a nem sportol még napi 10 percet sem (ELEF, 2014). A Magyar Ifjúság 2012-es eredményei is megerősítik az alacsony aktivitási szintet, hiszen az eredmények alapján a fiatalok 35\%-a sportol, és folyamatos csökkenő tendencia mutatkozik a rendszeres sportolás terén a kor előrehaladtával (Perényi 2013).

Hazai és nemzetközi kutatások alapján elmondható, hogy a fizikailag aktív serdülők elégedettebbek az életükkel és kevesebb depresszív tünetről számolnak be, mint azok, akik nem sportolnak rendszeresen (Pluhár et al. 2004, idézi Pikó \& Keresztes 2007). Emellett a rendszeresen sportoló fiatalok (amatőr és versenyszinten egyaránt) egészségesebbnek érzik magukat, reziliensebbek, boldogabbak (Kovács 2014) és elégedettebbek is önmagukkal (Kovács \& Perényi 2014).

A rizikómagatartásokra vonatkozó kutatási eredmények ambivalensek. Egyes kutatások szerint a fizikailag aktív fiatalok egészségesebben táplálkoznak, valamint a túlsúly kialakulásának kockázata is csökken náluk (Pate et al. 1996; Steptoe et al. 1997) és biztonságosabb szexuális életet élnek (Sabo et al. 1999). Közérzetük is jobb nem sportoló társaikkal összehasonlítva, valamint jobb edzettségi és egészségi állapotot tulajdonítanak maguknak, így a sportolói magatartás a jobb életminősséggel is párhuzamba hoz- 
ható (Pluhár et al. 2004). Tehát maga a sportolás hiánya is rizikófaktornak tekinthető (Kovács et al.2016). A dohányzással kapcsolatban is protektív faktort jelent a sportolás, hiszen a sportolók körében jelentősen alacsonyabb a dohányzás mértéke (Burke et al. 1997). Vannak azonban olyan kutatási eredmények is, amelyek pozitív kapcsolatot mutattak a sportolás és az egészségkárosító magatartások között, beleértve a dohányzást, alkohol- és drogfogyasztást és a promiszkuitást (szexuális partnerek gyakori váltogatása) (Faurie et al. 2004). Ez elsősorban élsportolóknál fordul elő, ahol a nagy nyomás és folyamatos teljesítménykényszer miatt a sportoló a felgyülemlett feszültséget szeretné oldani valamilyen módon, vagy éppen teljesítményét szeretné fokozni. Egyes kutatások szerint a versenyszerúen sportolók több alkoholt fogyasztanak, korábban kezdik az alkoholfogyasztást (Kovács 2014; Kovács 2013; Hildebrand et al. 2001). Éppen ezért nagyon fontos hangsúlyozni a megfelelő mértékben gyakorolt fizikai aktivitást.

\section{A család szerepe a kockázati magatartásban}

A család szerepe vitathatatlan a serdülő egészség- és rizikómagatartásának, illetve egészségtudatosságának formálásában (Pikó 2005). Ez az elsődleges szociális közeg, amely mintaként szolgál a gyermek számára nemcsak gyermekkorban, de felnőttkorban is. A serdülő számára egyre fontosabbá válnak a kortárskapcsolatok, ám a háttérben még támogató bázisként fontos marad a család is (Kovács \& Pikó 2009).

A családnak többféle védőszerepe is van a serdülók egészségmagatartásának tekintetében. Több kutatás is foglalkozott a szülőkhöz köthető szabadidős tevékenységek hatásával, amelyek protektív faktorként szolgálnak a gyermek értékrendjére és egészségtudatosságára nézve (Brassai \& Pikó 2005). Azon serdülők, akiknek szülei jobban odafigyeltek és kontrollálták gyermekük szabadidős tevékenységeit, kisebb valószínúséggel fogyasztottak alkoholt vagy drogot (Ford 2009; Järvinen \& Østergard 2009, idézi Kovács \& Pikó 2009). Éppen ezért jelent nagyobb kockázatot a családban bekövetkező strukturális válság.

A családszerkezet átalakulása kihat az egyén családdal való viszonyára, a kapcsolat erősségére, szocializációra, a biztonságérzetére és a társas támogatásra is (Kopp \& Skrabski 2001; Poortinga 2006). Kutatások szerint a család szerkezetében bekövetkező változás negatívan hat az egészségtudatos magatartásra, hiszen a kockázatvállaló és egészségkárosító viselkedések aránya magasabb azoknak a gyermekeknek a körében, ahol a családszerkezet nem ép. Az egyszülős családok gyermekeinek fiziológiai és érzelmi fejlődése is rosszabb, és jobban elköteleződnek a kockázatos tevékenységek iránt (Bramlett \& Blumber 2007). Az egyszülős családokban nevelkedő fiatalok körében magasabb a szerhasználat (Barrett et al. 2006; McArdle et al. 2002), valamint a korai szexuális tapasztalatok és serdülókori terhesség aránya is magasabb (Bonnel et al. 2006). A dohányzás valószínűsége a hagyományos kétszülős családban felnövő serdülók körében a legalacsonyabb, míg a mozaikcsaládok gyermekeinek esetében a legmagasabb (Griesbach 2003). Pikó (2005) egy 2004-es dél-alföldi ifjúságkutatás során 
kimutatta, hogy a nem intakt családi szerkezet is negatívan hat az egészségtudatos magatartásra, hiszen rizikótényező: az ilyen családból származó fiatalok körében magasabb a pszichoszomatikus és depressziós tünetek megjelenése, valamint a szerhasználat is. Emellett Hair és mtsai. (2009) kutatása kimutatta, hogy az alacsony kockázatot vállaló egyének (low-risk individuals), vagyis akik tartózkodnak az egészségkárosító és kockázatvállaló viselkedésformáktól, illetve elköteleződnek az egészséges magatartásformák mellett, túlnyomóan hagyományos családokból származnak.

Kovács és Pikó (2009) vizsgálták a családszerkezet hatását a serdülők egészségmagatartására, a dohányzás, az alkohol- és marihuánafogyasztás tekintetében szegedi gimnazisták körében. Eredményeik alapján csak a dohányzásnál mutatható ki szignifikáns különbség a szülők családi állapota alapján: a kétszülős családok gyermekeinél alacsonyabb, míg a válságot megélt családok gyermekeinél szignifikánsan magasabb arányban volt jelen a dohányzás. A közös családi étkezések is pozitív hatással vannak a gyermek és serdülő mentális egészségére, ugyanakkor ezeknek a mennyisége lecsökken vagy teljesen el is túnik a családban bekövetkező strukturális válság esetén (Compan et al. 2002).

\section{A kutatás bemutatása}

A vizsgálat célja egyrészt az egyes kockázati magatartások kipróbálásának felmérése, valamint az egészségkárosító magatartások kipróbálását esetlegesen befolyásoló háttérváltozók feltárása, kitérve a családszerkezetre, a sportolásra, valamint a szociokulturális háttérre. Ehhez a FASCES 2015 kutatás adatait vettük alapul, melyre az ország három keleti megyéjében, Borsod-Abaúj-Zemplén, Szabolcs-Szatmár-Bereg és Hajdú-Bihar megyékben került sor 627 tizedik osztályos tanuló bevonásával.

A kutatás során logisztikus regresszióanalízissel vizsgáltuk meg a dohányzás, alkoholfogyasztás, valamint a marihuána és kemény drogok ${ }^{2}$ kipróbálására ható tényezőket. A vizsgálatba bevont változókat három csoportba soroltuk: a családszerkezet, a sportolás (jelen esetben az iskolai vagy iskolán kívüli, legalább heti rendszerességgel történő fizikai aktivitás), valamint a társadalmi háttérváltozók csoportjait különítettük el. A társadalmi változók kategóriájába jelen kutatásban a nem, a településtípus (város vagy falu), a szubjektíven megítélt átlaghoz viszonyított anyagi helyzet (átlag alatti vagy feletti), valamint a szülők foglalkozási státusza (van-e munkaviszonya vagy sem) került bevonásra. A viszonyítási alapot a hagyományos családban nevelkedő gyerekek értékei képezték, tekintve, hogy az ő esetükben volt a legalacsonyabb a kipróbálási arány valamennyi kockázati magatartás tekintetében. A logisztikus regresszióanalízis kiegészítéséhez Chi-négyzet-próbát és kétmintás t-próbát alkalmaztunk az adatok normális eloszlására való tekintettel ( $\mathrm{p}>0,05)$.

2 Könnyủ drogok: nem erôsen addiktív illegális szerek, pl. marihuána, LSD, mágikus gombák. Kemény drogok: addiktív és akár injektálható kábítószerek, pl. heroin, kokain, metamfetamin. 


\section{Dohányzás}

A dohányzás esetében önmagában sem a családszerkezet, sem a mozgás nem befolyásolja szignifikáns mértékben a kipróbálást. A továbbiakban bevont háttérváltozók közül a nem, a lakóhely településtípusa, valamint a szülők foglalkoztatottsága nem jelent szignifikáns befolyásoló tényezőt. A tanulók által szubjektíven megítélt anyagi helyzet azonban szignifikánsan befolyásolja a dohányzás kipróbálásának valószínűségét $(p=0,035)$. A kétmintás t-próba és regresszió eredményei alapján elmondható, hogy azok, akik átlag felettinek ítélik meg családjuk anyagi helyzetét, szignifikánsan nagyobb az esélye, hogy kipróbálják a cigarettázást az átlag alatti anyagi helyzetben élő társaikkal összehasonlítva $(p=0,029)$. A regresszióanalízis eredményei az 1. táblázatban olvashatóak.

1. táblázat. A logisztikus regresszió eredményei a dohányzás kipróbálási arányának tekintetében $(\mathrm{ExpB})$

\begin{tabular}{|l|c|c|c|}
\hline & 1. modell (ExpB) & 2. modell (ExpB) & 3. modell (ExpB) \\
\hline Egyszülős család & 1,213 & 1,200 & 1,536 \\
\hline Újrastrukturált család & 1,929 & 1,931 & $2,056^{*}$ \\
\hline Mozgás & & 0,865 & 0,892 \\
\hline Nem & & & 0,980 \\
\hline Anyagi helyzet & & & $1,537^{*}$ \\
\hline Településtípus & & & 0,893 \\
\hline Apa dogozik & & & 1,724 \\
\hline Anya dolgozik & & $2,032^{* * *}$ & 0,957 \\
\hline Constant & $1,987^{* * *}$ & ${ }^{*} \mathrm{p}<0,05,{ }^{* *} \mathrm{p}<0,01,{ }^{* * *} \mathrm{p}<0,001$ \\
\hline
\end{tabular}

A családszerkezet és az anyagi helyzet együttesen is befolyásolják a dohányzás kipróbálási valószínűségét. A Chi-négyzet-próba eredményei szerint azoknak a hagyományos családmodellben nevelkedő gyerekeknek a körében kisebb a kipróbálók aránya, akiknél az anyagi helyzet átlag alatti, szemben a válságon átesett családok gyermekeinél (átlag alatti anyagi helyzet esetén hagyományos családmodellben 63,2\%, az egyszülős családmodellben 71,6\%, az újrastrukturált családmodellben 79,1\% a kipróbálók aránya). Ugyanakkor azon családok esetében, ahol az anyagi helyzet átlag feletti, a kipróbálási arány magasabb a hagyományos családmodellben nevelkedők körében $(74,8 \%)$ és az újrastrukturált családban élők körében $(82,4 \%)$, míg az egyszülős családok esetében kisebb a kipróbálási esély $(66,7 \%)(\mathrm{p}=0,007)$. Vagyis az átlag alatti anyagi helyzet az egyszülős családok esetében jelent kockázati tényezőt, míg az átlag feletti anyagi helyzet a hagyományos és újrastrukturált családmodellben élő gyermekek számára, így elmondható, hogy a családszerkezet megváltozása növeli a dohányzás kipróbálásának esélyét. A regresszióból is azt láthatjuk, hogy az újrastrukturált családban élő gyereknek kétszer, az átlag feletti anyagi helyzetben lévő gyerekeknek pedig másfélszer nagyobb az esélyük a dohányzás kipróbálására. 


\section{Alkoholfogyasztás}

Az alkoholfogyasztás kapcsán azt vizsgáltuk meg, hogy előfordult-e már, hogy lerészegedett a kitöltó. Ennek tekintetében is elmondható, hogy önmagában a családszerkezet, valamint a mozgás nem befolyásolja szignifikánsan azt, hogy a serdülő volt-e már részeg. A nem $(\mathrm{p}=0,001)$, a településtípus $(\mathrm{p}=0,020)$, a szubjektíven megitélt anyagi helyzet $(p=0,013)$ és az apa foglalkoztatottsága $(p=0,022)$ esetében volt kimutatható szignifikáns összefüggés a túlzásba vitt alkoholfogyasztással. A logisztikus regresszió további eredményeit az alábbi táblázat szemlélteti:

2. táblázat. A logisztikus regresszió eredményei a lerészegedés kipróbálási arányának tekintetében $(\operatorname{ExpB})$

\begin{tabular}{|l|c|c|c|}
\hline & 1. modell $(\operatorname{ExpB})$ & 2. modell $(\operatorname{ExpB})$ & 3. modell (ExpB) \\
\hline Egyszülős család & 1,512 & 1,502 & $2,145^{* * *}$ \\
\hline Újrastrukturált család & 1,360 & 1,362 & 1,746 \\
\hline Mozgás & & 0,916 & 0,854 \\
\hline Nem & & & $1,796^{* * *}$ \\
\hline Anyagi helyzet & & & $0,651^{*}$ \\
\hline Településtípus & & & $1,619^{*}$ \\
\hline Apa dogozik & & & $1,964^{*}$ \\
\hline Anya dolgozik & & $1,341^{* * *}$ & 1,457 \\
\hline Constant & $1,323^{* * *}$ & & 0,460 \\
\hline
\end{tabular}

Forrás: FASCES $2015(N=611)$

$$
{ }^{*} \mathrm{p}<0,05,{ }^{* *} \mathrm{p}<0,01,{ }^{* * *} \mathrm{p}<0,001
$$

A kétmintás t-próba és a logisztikus regresszió eredményei alapján a nemek tekintetében a fiúk körében mutatkozott magasabbnak a túlzásba vitt alkoholfogyasztás megjelenési aránya $(\mathrm{p}=0,000)$, vagyis a fiúk esetében szignifikánsan magasabb az esélye annak, hogy volt már részeg, ami megfelel a korábbi hazai és nemzetközi eredményeknek. A nem bevonásával már a családszerkezetbeli különbségek is jelentôsnek mutatkoztak: a Chi-négyzet-próba eredményei alapján az egyszülős családban nevelkedő fiúk körében jelentősen magasabb arányban fordult már elő lerészegedés $(75,8 \%)$, összehasonlítva a másik két családszerkezeti típussal (hagyományos családban 66\%, újrastrukturált családban 64,3\%) ( $\mathrm{p}=0,001)$. Vagyis az egyszülős családban nevelkedő gyerekek nagyobb veszélynek vannak kitéve, még az újrastrukturált társaikkal összehasonlítva is.

Az anyagi helyzet megítélésének tekintetében is eltérések mutatkoztak a kipróbálást illetôen ( $\mathrm{p}=0,013)$. Azok a tanulók, akik családjuk anyagi helyzetét átlag felettinek itélik meg, nagyobb arányban tapasztalták már meg a lerészegedést (66,8\%), összehasonlítva azon kortársaikkal, akik anyagi helyzetüket átlag alattinak ítélik meg (55,6\%), $\mathrm{s}$ a regresszió eredményei alapján nagyobb esélyük is van a lerészegedésre. Vagyis azok a gyerekek, akik jobb anyagi helyzetben élnek, nagyobb veszélynek vannak kitéve.

Emellett a településtípus hatása mutatkozott szignifikánsnak: a Chi-négyzet-próba eredményei alapján a faluban élő serdülők körében magasabb a kipróbálási arány va- 
lamennyi családtípus esetében (hagyományos családmodell: 58,9\%, egyszülös családmodell: 82,6\%, újrastrukturált családmodell: 66,7\%), mint a városban élők esetében (hagyományos családmodell: 55,7\%, egyszülős családmodell: 60,4\%, újrastrukturált családmodell: $61,0 \%)$. Tehát a falun élők veszélyeztetettebbek a túlzott alkoholfogyasztás tekintetében $(\mathrm{p}=0,020)$. Ugyanakkor a regresszió eredményei azt mutatják, hogy a családtípustól függetlenül a városban élőknek 1,6-szor nagyobb az esélyük a nagy mennyiségú alkoholfogyasztásra.

Végül az apa foglalkozási státusza számít szignifikáns befolyásolási faktornak $(\mathrm{p}=0,022)$. Azon gyerekek körében magasabb a lerészegedés előfordulásának aránya, akiknek édesapja vagy nevelőapja dolgozik (59,8\%), a dolgozó apák gyerekeinek esélye a lerészegedésre pedig majd kétszeres, míg akiknek édesapja vagy nevelőapja nem dolgozik, ez az arány kisebbnek mutatkozott (46,9\%). Ezen eredmények alapján úgy tűnik, hogy az apa munkanélkülisége visszatartó erőt jelent a serdülők számára.

\section{Szerhasználat}

A szerhasználat kapcsán a kemény drogok kipróbálását vizsgáltuk meg, amely esetében elmondható, hogy a családszerkezet hatása szignifikáns a kipróbálás tekintetében, hiszen az eredmények alapján jóval nagyobb a kemény drogok kipróbálási esélye azon serdülók körében, akiket egy szülő nevel (hagyományos családmodell: 2,0\%, egyszülős családmodell: 7,8\%, újrastrukturált családmodell: $3,3 \% ; \mathrm{p}=0,035)$. Bár a vizsgált változók bevonásával csökkent a családszerkezet befolyásoló ereje a regressziós modellekben, de egyértelmúen látható az egyszülős család negatív hatása: mintegy 3,3-szor nagyobb az esélye a drogok kipróbálásának egy ilyen családban nevelkedett gyerek esetében a hagyományos családban nevelkedő gyerekekhez képest, függetlenül minden más vizsgált változó hatásától. Mindazonáltal sem a sportolás, sem a többi demográfiai háttérváltozó nem mutatkozott szignifikáns faktornak a kemény drogok kipróbálását illetően. A logisztikus regresszió eredményei a következő táblázatban olvashatók:

3. táblázat. A logisztikus regresszió eredményei a kemény drogok kipróbálási arányának tekintetében

\begin{tabular}{|l|c|c|c|}
\hline & 1. modell $(\operatorname{ExpB})$ & 2. modell (ExpB) & 3. modell (ExpB) \\
\hline Egyszülős család & $3,478^{*}$ & $3,421^{*}$ & $3,374^{*}$ \\
\hline Újrastrukturált család & 1,455 & 1,456 & 1,328 \\
\hline Mozgás & & 0,739 & 0,808 \\
\hline Nem & & & 0,695 \\
\hline Anyagi helyzet & & & 0,544 \\
\hline Településtípus & & & 1,116 \\
\hline Apa dogozik & & & 0,774 \\
\hline Anya dolgozik & & $0,026^{* * *}$ & 0,563 \\
\hline Constant & $0,025^{* * *}$ & & $0,077^{* * *}$ \\
\hline
\end{tabular}

Forrás: FASCES $2015(N=610)$

${ }^{*} \mathrm{p}<0,05,{ }^{* *} \mathrm{p}<0,01,{ }^{* * *} \mathrm{p}<0,001$ 
Látható tehát, hogy a sportolás nem befolyásolja jelentős mértékben a kemény drogok kipróbálási arányát, bár a kétmintás t-próba eredményei alapján is alapvetően a sportolók körében kisebb mértékben fordult elő a kipróbálás (sportolók: 2,3\%, nem sportolók: 3,2\%), ugyanakkor a különbség nem szignifikáns ( $\mathrm{p}=0,649)$.

\section{Összegzés}

Az egészségkárosító magatartásformák kipróbálását illetően a logisztikus regressziószámítások alapján elmondható, hogy csupán a mozgás nem befolyásolja jelentős mértékben a kipróbálást, bár tendenciaszinten megjelent a sportolás protektív hatása. Emellett a családszerkezet önmagában sem szignifikáns befolyásoló tényező. Kivételt ez alól csak a kemény drogok kipróbálása jelenti, hiszen ebben az esetben eleve szignifikáns különbség mutatható ki a kipróbálást illetően, tekintve, hogy az egyszülős családban nevelkedő serdülők magasabb arányban találkoztak már kemény droggal. Mind az egy szülővel, mind az újrastrukturált családban felnövő gyermekek értékei rosszabbak a hagyományos családban élő kortársaikkal összehasonlítva, amely jól mutatja a család stabilitásának és megtartó erejének fontosságát. Fontos megjegyezni továbbá, hogy bár újrastrukturált családban két szülő van jelen, így anyagi és érzelmi támogatás is két oldalról érkezik, mégis nagyobb a kockázati magatartások jelenléte, hiszen az eredeti családmodellben bekövetkező változás komoly stresszforrást jelent a gyermek számára.

A társadalmi háttérváltozók hatása kimutatható, több esetben ezek bevonásával mutathatók ki a családszerkezet alapján fennálló különbségek, tekintve, hogy ezek a változók egymástól nem függetlenek (például a strukturális válságon átesett családok szocioökonómiai státusza rosszabb). Ilyen változó a szubjektíven megítélt anyagi helyzet, a nem, a település típusa és az apa foglalkozási státusza.

Az eredmények felhívják a figyelmet a családban bekövetkező strukturális válság hatásának, valamint a mozgás szerepének fontosságára. A válság miatt fellépő problémák hatékony kezelésében fontos az iskola szerepe, ahol a serdülő napközben ideje nagy részét tölti. Abban az esetben, ha a fiatalnál deviáns magatartás tapasztalható (akár egészségkárosító, akár egyéb magatartási zavar), szükséges az intervenció. A pedagógusok (gimnáziumban elsősorban az osztályfőnök) feladata a probléma észlelése, kapcsolatfelvétel az elérhetô szülővel, empatikus odafordulás a serdülő felé, szükség esetén pedig szakember, például iskolapszichológus segítségének kérése. Ugyanakkor az intervenció mellett a prevenció szerepe is óriási, amelynek segítségével visszaszorulhat a kockázati magatartásformák kipróbálásának aránya. 


\section{Hivatkozott irodalom}

- Barrett, A. E. \& Turner, J. (2006). Family structure and substance use problems in adolescence and early adulthood: examining explanations for the raltionship. Addiction, (101), 109-120.

- Bonnel, C., Allen, E. \& Strange, V. (2006). Influence of family type and parenting behaviours on teenage sexual behaviour and conceptions. Journal of Epidemiology \& Community Health, (60), 502-506.

- Bramlett, M. D. \& Blumberg, S. J. (2007). Family structure and children's physical and mental health. Health Affairs, 26 (2), 549-558.

- Brassai L. (2010). Válasz a kockázati társadalomra: az élet értelmességébe vetett hit. Sepsiszentgyörgy, T3 Kiadó.

- Brassai L. \& Pikó B. (2005). Szerhasználat és családi tényezők viszonya középiskolásoknál. Addictologica Hungarica, 4 (1), 7-29.

- Burke, V., Milligan, R. A. K., Beilin, L. J., Dunbar, D., Spencer, M., Balde, E. \& Gracey, M. P. (1997). Clustering of health-related behaviors among 18-year-old Australians. Preventive Medicine, (26), 724-733.

- Compan, E., Moreno, J. \& Ruiz, M. T. (2002). Doing things together: adolescents health and family rituals. Journal of Epidemiology \& Community Health, (56), 89-94.

- Conner,M. (2005). Health behaviours. Forrás: http://userpage.fu-berlin.de/ schuez/ folien/conner2002.pdf. Utolsó letöltés: 2016. 02. 01.

- Csizmadia P. \& Várnai D. (2003). Dohányzás és alkoholfogyasztás. In Aszmann A. (szerk.): HBSC Iskoláskorú gyermekek egészségmagatartása (pp. 49-60). Budapest, Országos Gyermekegészségügyi Intézet.

- ELEF (2014). Európai lakossági egészségfelmérés, 2014. Statisztikai tükör, (29), 1-9.

- Faurie, C., Pontier, D. \& Raymond, M. (2004). Student athletes claim to have more sexual partners than other students. Evolution and Human Behavior, (25), 1-8.

- Ford,J. A. (2009). Nonmedical prescription drug use among adolescents: The influence of bonds to family and school. Youth \& Society, (40), 336-352.

- Goldberg, J. H., Halpern-Felsher, B. L. \& Millstein, S. G. (2002). Beyond invulnerability: The importance of benefits in adolescents' decision to drink alcohol. Developmental Psychology, 6, 415-428.

- Griesbach, D., Amos, A. \& Currie, C. (2003). Adolescent smoking and family structure in Europe. Social Science and Medicine, (56), 41-52.

- Hair, E. C., Park, M. J. \& Ling, T. J. (2009). Risky behaviors in late adolascence: co-occurence, predictors and concesquences. Journal of Adolescence Health, (45), 253-261.

- Hildebrand, K. M., Johnson, D. J. \& Bogle, K. (2001). Comparison of patterns of tobacco use between high school and college athletes and non-athletes. American Journal of Health Education, (32), 75-80.

- Kopp M. \& Skrabski Á. (2001). Magatartás és család. Magyar Bioetikai Szemle, 7 (4), 1-25. 
- Kovács E. \& Pikó B. (2009). A család egészségvédő hatása serdülők körében. Mentálhigiéné és Pszichoszomatika, 10 (4), 223-237.

- Kovács K. (2013). Sportoló közösségekhez tartozás mint társadalmi védőfaktor. Educatio, (2), 264-270.

- Kovács K. (2014a). Boldogító mozgás. A sportolás hatása a partiumi hallgatók szubjektív jóllétére, lelki edzettségére és egészségének önértékelésére. Kapocs, (2), 2-13.

- Kovács K. (2014b). A sportolás hatása a partiumi hallgatók nem tanulmányi eredményességének egyes dimenzióira. In Ceglédi T., Gál A. \& Nagy Z. (szerk.): Határtalan oktatáskutatás. Tanulmányok a 75 éves Kozma Tamás tiszteletére (pp. 275288). Debrecen, Kapitális Kft.

- Kovács K., Kovács K. E. \& Nagy B. E. (2016). Intézményi hatások a hallgatók egészségtudatos magatartásában. In Pusztai G., Ceglédi T. \& Bocsi V. (szerk.): A felsöoktatás (hozzáadott) értéke (pp. 174-190). Közelítések az intézményi hozzájárulás empirikus megragadásához. Nagyvárad-Debrecen, Partium Press, Új Mandátum Könyvkiadó.

- Kovács K. \& Perényi Sz. (2014). A sportolás és egészség. Kapcsolatok a fiatalok fizikai, mentális és szociális jóllétének szubjektív szintjével. In Nagy Á. \& Székely L. (szerk.): Másodkézböl. Magyar Iffúság 2012 (pp. 245-262). Budapest, Kutatópont.

- Lohaus, A., Vierhaus, M. \& Ball, J. (2009). Parentig styles and healthrelated behaviour in childhood and early adolescence: results of a longitudinal study. The Journal of Early Adolescence, (29), 449-475.

- McArdle, P., Wiegersma, A. \& Gilvarry, E. (2002). European adolescent substance use: the roles of family structure, function and gender. Addiction, (97), 329-336.

- Németh Á. (2003). Nemi érés és szexuális magatartás. In Aszmann A. (szerk.): HBSC Iskoláskorú gyermekek egészségmagatartása (pp. 77-85). Budapest, Országos Gyermekegészségügyi Intézet.

- Németh Á. \& Költő A. (szerk., 2011). Serdülókorú fiatalok egészsége és életmódja 2010. Budapest, Országos Gyermekegészségügyi Intézet. Forrás: http://www. ogyei.hu/anyagok/HBSC_2010.pdf. Utolsó letöltés: 2016. 05.25.

- Pate, R. R., Heath, G. W., Dowda, M. \& Trost, S. G. (1996). Associatins between physical activity and other health behaviors in a representative sample of US adolescents. American Journal of Public Health, (86), 1577-1781.

- Perényi Sz. (2013). Alacsonyan stagnáló mozgástrend: a fizikai inaktivitás újratermelődése. In: Székely L. (szerk.): Magyar Iffúság tanulmánykötet 2012 (pp. 229 249). Budapest, Kutatópont.

- Pikó B. (2005). Középiskolás fiatalok szabadidő-struktúrája, értékattitúdjei és egészségmagatartása. Szociológiai Szemle, (2), 88-99.

- Pikó B. \& Keresztes N. (2007). Sport, lélek, egészség. Budapest, Akadémiai Kiadó.

- Pluhár Zs., Keresztes N. \& Pikó B. (2004). A rendszeres fizikai aktivitás és pszichoszomatikus tünetek kapcsolata általános iskolások körében. Sportorvosi szemle, (4), 285-300. 
- Poortinga, W. (2006). Social relations or social capital? Individual and community health effects of bonding social capital. Social Science \& Medicine, (63), 255-270.

- Rothspan, S. \& Read, S. J. (1996). Present versus time perspective and HIV risk among heterosexual college students. Health Psychology, 15, 131-134.

- Sabo, D. F., Miller, K. E., Farell, M. P., Melnick, M.J. \& Barnes, G. M.(1999).High school athletic participation, sexual behavior and adolescent pregnancy: A regional study. Journal of Adolescent Health, (25), 207-216.

- Sebestyén E. (2003). Illegális szerek használata. In Aszmann A. (szerk.): HBSC Iskoláskorú gyermekek egészségmagatartása (pp. 61-76). Budapest, Országos Gyermekegészségügyi Intézet.

- Steptoe, A., Wardle, J., Fuller, R., Holte, A., Justo, J., Sanderman, R. \& Wichstrøm, L. (1997). Leisure-time physical exercise: prevalence, attitudinal correlates, and behavioral correlates among young Europeans from 21 countries. Preventive Medicine, (26), 845-854.

- Susánszky É. \& Szántó Zs. (2002). Az egészségi állapot szempontjából veszélyeztetett fiatalok demográfiai és társadalmi jellemzői. In Szabó A., Bauer B. \& Laki L. (szerk.): Ifuiság 2000. Tanulmányok I. (pp. 154-165). Budapest, Nemzeti Ifjúságkutató Intézet. 


\title{
SORIN BuHaȘ
}

\section{Sports and Physical Education - Determinants of Social Integration Among Students in Romania}

\begin{abstract}
Social integration through sports is a complex and universal phenomenon. Following social, political, cultural, economic diversity in different countries, socialization and social integration know an intense diversification. Thus, the importance of structuring specific sports policies for each country arises. In this context, sport and physical education are critical factors in social integration of school population. There are theoretical and empirical approaches regarding the effects of social integration through sports. They mostly highlight the positive aspect of sport on the personality of those who practice it, especially on school population. Sports and physical education contribute to socialization and social integration through movement, but especially through its effect on the youngsters' personality. Sport has a great influence on assuming responsibilities, following rules, strengthening self-esteem and self-identity. Sports develop a wide range of cultural, social and behavioral attitudes that will fold on youngsters' daily activity. There is a proven relationship between sports and moral values. All these components must be developed and linked to the daily activities of school population. In an integrating context, research on the social impact of sports focused on socialization through sports, but also on sports' social impact. A positive influence of sports on the health and personality of those who practice it can be noticed, but also one can observe sports' contribution to social integration through movement and the influence of movement on personality development. Also, doing sports establishes and develops social contacts which contributes to the development of personality, and human- and moral values. Doing a highly popular activity, sports offer a wide range of pleasant experiences: passion, feelings, taste of success, which makes it an important medium for social integration, fostering contacts and social relations. The most important integration factors are cooperation between individuals, spontaneous individual activities and the freedom to choose and decide.
\end{abstract}

\section{Introduction}

Social behavior is mainly determined by individual personality traits and by the relationship between physical and mental levels. It is generally accepted that sport and physical activity are important components in the social integration process, based on 
a wide range of social contacts. Sports, as an evolutionary component of social life, is becoming more present in our daily activities (Buhaș 2015). It is important to determine the mechanisms of this process: whether physical activity in its essence determines the development of individual skills, or if the social nature of sports influences the social integration of individuals who practice physical activity. „Sports, by its manifestations and organization forms has become an inseparable part of society in general, the difference between being qualitative and quantitative, and whose value is generated by individuals' involvement degree as part of the society" (Ilieș et al., 2014: 7).

The aim of the present paper is both to present in a synthesized way the theoretical approaches from the literature and to establish how sport and physical education represent a framework for socialization and integration. Theoretical approaches are extremely wide, comprising different empirical studies focusing on the socialization process. The present paper aims to be a theoretical analysis based on literature review; mainly, the analysis puts an emphasis on the ideas of certain scholars that have marked this area of research - sports.

Socialization is considered to be "the process through which individuals acquire skills, attitudes, values and behaviors that make them able to participate as members of the society« (Sage et al. 1986a: 24).

The framework of socialization can be represented by any environment that allows this process to occur, constituting a complex and heterogeneous structure (Dragoș 2012). We sustain that sport and physical education are part of this environment, obviously alongside with other determinants. Therefore, physical activity is represented by any component activity of the so called sports phenomenon.

\section{Characteristics of socialization process}

Most individuals believe that sport and physical activities develop positive social components of peoples' personality. Many are convinced that sports offer , a favorable framework for the development of culturally appreciated social and personal attitudes, values and behaviors, and what is learned through physical activity is transferred also to other spheres of life" (Sage 1986b: 22).

Abele and Brehm (1989) identify eight characteristics on youth development, which could complete the socialization process in adulthood:

- accepting own body

- understanding the role of women and men

- building relationships with other people

- emotional independence

- preparation for a profession and family life

- social responsibility

- defining a value system

- moral behavior 
These authors, and many others, believe that sports activity is only one component of socialization. A sociological research (Buhaș \& Bălţătescu 2013) identified another component commonly encountered by Romanian students (from the NorthWestern border): the online environment; an extremely high Internet consumption was registered, the daily average being of 100 minutes distributed for various activities such as information, communication, entertainment. Therefore, the direct stimulation regarding the social integration through sports activities is advisable. Sports as leisure activity has a major influence on socialization, being at the same time a development factor for social relations (Lucaciu et al. 2014).

Although it represents a socialization factor, sports experience can be overcome by other personal influences. From a sociological point of view, sport is seen as a social institution (Ikulayo 1992). Sage (1988) considers that an organized way of practicing sport has a predominant influence in the socio - cultural area. In well-structured societies, the number of individuals practicing sports in an organized manner is extremely high. In the USA more than 30 million of boys and girls are involved in youth sports projects, and more than 6.5 million teenagers participate in interschool sports competitions. According to a study carried out in 2010 by The Romanian National Institute of Statistics, in Romania the number of legitimated athletes is extremely low - only 234.569 athletes, representing $1.2 \%$ of the total population. In France this percentage is $25 \%$ of the total population (Enciu 2012). Through his studies, Sage demonstrates that sports play a decisive role in the lives of millions of participants. He states that: "the social world of sports is not presented as a given entity, controlled by unalterable natural laws, but as socially constructed processes that can be transformed by human agents" (Sage 1988: 47).

Among sports effects, Furnham (1990) outlines also lifestyle changes (how we eat, drink, rest, etc.). These changes are also generated by different social group interactions between society members; they alter behavior patterns or manifestations of personality. Obviously, not all changes can be easily outlined, because they manifest in long periods of time. Even though, it is assumed that there are „several potential ways based on which sports participation can serve as a path for social mobility" (Sage 1986b: 363).

Orlick (2008) highlights the importance of team sports in establishing cooperation relations. Athletes are conditioned to work as a team, due to the nature of sport. Orlick (2008) emphasizes communication, mutual respect, friendly atmosphere, etc., which contribute to the quality of social relations. Thus, the changes that occur in sports practitioners' socialization process can only be achieved only through social learning and interaction with other sports' participants. On the other hand, Pop (2012) considers that individual sports (mountain biking) develop physical and inner strength, and self-confidence, aspects that emphasize the social integration of practitioners. 


\section{Physical education and sports - sources of socialization}

So far, we have noticed that there is a constant and continuous concern regarding the positive influence of practicing sport and physical education in an organized framework. Kaschuba (1989) highlights the idea of social integration, the need for social and emotional contact, which appears only in certain contexts, within particular social groups and arises from specific situations: like certain groups that practice sports in an unorganized way. A professional activity (work, school etc.) can generate the need for extra-professional activities as a result of establishing interpersonal relationships between people; such extra-professional activities can strengthen social relations. They are not organized based on classic criteria, regulations or statutes, but prefer to practice physical exercises in a limited framework, mainly aiming at establishing social contacts. Therefore, sports can become a model of social integration based on contacts and relationships linked to a particular group interest. This approach appears particularly related to recreational sports. In order to perform in various social contexts (work, school, etc.) and for an adequate social integration, a good health and physical condition are important, but also the exercise of social networking, acquired through sports. The contacts between individuals are determinant, but other qualities such as cooperation, social adaptability, friendship, teamwork, etc., do not appear and are not natural emissions resulting from practicing sports. They should be fostered, so that competition can settle them. Thus, the need for systematic physical activity in order to achieve social objectives is being highlighted.

Bunting (1989) states that competition and integration do not occur only between teams, but especially within each team. If competition generates rivalry between teams, this must be seen in terms of fair play, respect for competition rules and customs, and not in terms of a confrontation with a potential enemy. Thus, the opponent is a partner and not an adversary. Also, this kind of competition develops and strengthen interpersonal relationships within each team, as a result of the desire to achieve a common goal.

Cratty (1967) identifies other source of socialization: the involvement in social activity. This involves motivating individuals for a superior performance. This can generate a behavioral change leading to better social integration. Social actors have a very positive reaction in relation with other social participants, having an avant-garde image and sensing other group's interventions. Cratty explains: „motric performance is typically affected by the social implications of the immediate situation, but also by the general cultural context in which the action takes place. When individuals learn new skills, they are concerned not only by the specifics of their responsibility, but also by the way in which cultural context integrates their performance. Thus, the performer is always sensitive to the degree to which his performance may coincide or not with cultural expectations" (Cratty 1967: 23).

Telama (1998) states that extended social contact has a major role. In order to sustain his idea, he discusses a famous experience of a group of boys who were able to stop hostilities between them when they were forced to solve an important cultural 
task which met a mutual interest. Telama (1998) outlines the desire to help others, to develop empathy, to embrace an altruistic behavior and social responsibility. Social integration is directly related to personality and moral values development. The quality of the environment in which sports and physical education activity develop depends also on the personality traits of people involved. Morally speaking, it is about the famous expression of fair play. The question is whether practitioners „tend to behave according to the most elevated moral judgment patterns, even when conventions or success strategies would encourage alternative behaviors" (Weiss \& Bredemeier 1986: $375)$. We can speak about social inclusion in sport only when we can identify moral qualities.

\section{Physical activity - factor of social integration}

Some studies highlight the importance of sports practice in learning social integration even since early childhood. A pioneer of this theory was Piaget (Piaget \& Inhelderova 1970), who made the connection between play and cognitive development, and Kohlberg related cognitive and moral development stages. Through play, the child assumes different social roles and learn important social functions. The child „takes over and plays roles that exist, both in the immediate and social world and, while embodying these roles, the child learns to come out of himself, developing in this way a reflection of himself as a social object different from others, but also linked to others" (Sage 1986a: 23). By participating in games, children learn to perceive others' roles, learning to orient themselves, becoming members of society. The game is one of the necessary means for ,successful social adaptation during childhood, serving also as the basis for adulthood manifestation in society" (Sage 1986a: 24). According to Sage, sports and physical activity, especially games, can be means of socialization and social integration. What is not known with certainty is the framework in which sports practice represents a positive environment for socialization, but experience leads us to have a positive approach in this regard. Children, under the pressure of external factors (parents, acquaintances, relatives, friends, etc.) become more concerned to win, than to be fair and embrace fair play. In time, this approach fades, and other values become predominant. Sage (1986b) considers that research fail to give clear answers regarding the link between physical exercise and its effect on social inclusion.

Robertson (1982) considered important social factors like friendship and cooperation during social interaction through sports. An interesting research was conducted by Parlebas (1987). He has determined that within the group structure, physical activity has changed relationships between individuals. Parlebas (1987) states that in the case of team sports, cohesion is highlighted only through the antagonism between the participating teams. Another research was conducted by Thill (1988). He addresses personality differences between athletes and non-athletes. Thill (1988) shows that sociability and cooperation are much stronger among groups of children. Ungerer, 
Rohrich (1988) conducted a study during physical education lessons, addressing aspects related social competence increase through specific sports activities. It appears that it generated an increase in students' competence through interaction and social integration during physical education lessons.

Research carried out in Romania by Gavriluţă and Gavriluţă (2010) identifies three directions on socialization and social integration through sport.

Socialization through sport- sports sociability is transferred to society.

Socialization in sports - refers to professional sports, where rules are very strict; rules compliance generates the concept of "team spirit" which is inevitably transferred in society.

Socialization in sports contexts - the degree of individual involvement from audience perspective.

In this context, the author emphasizes that sports activity „can be goal, means and context for achieving socialization" (Gavriluţă \& Gavriluţă 2010: 73) and social integration. The authors capture the effects of social integration through sport:

- develops a certain lifestyle (discipline, organization, punctuality, conduct, etc.)

- develops communication and new networking strategies (shy and introvert youngsters are guided to practice team sports)

- reduces social and individual tensions (sport for recreation and disconnection)

- fosters team spirit and enhances self-confidence (develops the idea of social belonging and team spirit)

\section{Conclusions}

The action of sports and physical activity on social integration is a wide concept; therefore, it cannot be addressed through some trenchant conclusions. The above mentioned authors are convinced that sports can be an auspicious factor for social integration, even if the object of their studies is based on qualitative approaches on a longer period of time.

As a result of their global nature, sports and physical activity are an ideal opportunity to communicate and meet new people, to acquire and assume new roles and social skills, to accept other attitudes and emotional experiences. Besides, Culeva states that "the recipe for success in children and youth sports is a mixture of social affiliation, elements of competition in different doses and forms, in a stimulating environment for learning, pleasure trips, that enhance team cohesion and bring more fun in sports experience" (Culeva \& Pătru 2000: 25). Also, sports generates teamwork skills helping to support the performance of an entire community.

From the age perspective, youngsters discover the process of learning social roles through which sports contribute to better social integration.

Sport provides the opportunity to develop communication and social understanding skills. Thus, the main goal of sports practice is represented by the free association of individuals in order to establish social contacts. 
Physical activity is an important component of personality development as a result of the unitary link between body and mind. Sports develops and places on healthy principles and self-esteem, regulates and controls anxiety reactions, depression, stress, but also positive energy and wellbeing.

Even if we do not have tangible scientific evidences regarding the positive influence of sports practice on social integration, but based on various information in this area, makes us accept and sustain this influence. It is desirable to focus on the quality of learning attitudes and social skills especially in relation to youngsters.

\section{References}

- Abele, A. E. \& Brehm, W. (1989). Changes in the state of being in physical education through the variation of work load and rhythm. International Journal of Physical Education, 26, 11-18.

- Buhaș, S. (2015). Sport Management - Science and Art. Analele Universității din Oradea - Fascicula Educație Fizică și Sport [Annals of the University of Oradea - Physical Education and Sport Fascicle], (25), 85-89. Source: http://www.fefsoradea.ro/Fascicula_Educatie_Fizica_si_Sport/2015/12.FEFS_2015_Buhas.pdf. Downloaded: 2016. 08. 25.

- Buhaş, R. \& Bălţătescu, S. (2013). Types of Internet Usage among Higher Education Students in the Romanian-Hungarian Cross-border Area, Sociologie românească [Romanian Sociology Journal], 9 (3), 99-122. Source: http://www.arsociologie.ro/ en/rezumat/1377-buhas-si-baltatescu-3-2013. Downloaded: 2016. 08. 25.

- Bunting, C. J. (1989). The Compatibility of Physical Education and Outdoor Education. JOPERD, (2), 35-43.

- Cratty, J. B. (1967). Movement Behavior and Motor Learning. Philadelphia, Lea \& Febiger.

- Culeva, A. \& Pătru, A. (2000). Sociologia sportului - culegere de lecţii [Sociology of Sports - collection of lessons]. Constanța, Ex Ponto Press.

- Dragoș, P. (2012). Influenţa condiţiilor de mediu şi a celor de muncă asupra managerilor şi angajaţilor din organizaţiile sportive [The influence of environment and work conditions over managers and employees of sports organizations]. Analele Universității din Oradea - Fascicula Educație Fizică și Sport [Annals of the University of Oradea - Physical Education and Sport Fascicle], (25), 13-21. Source: http:// www.fefsoradea.ro/Fascicula_Educatie_Fizica_si_Sport/2012/2.FEFS_2012_ Dragos.pdf. Downloaded: 2016.08.25.

- Enciu, A. (2012). Toţi vor să fie Dodel, nimeni nu mai vrea să fie Nadia! Dovada HAOSULUI din sportul românesc: „Degradarea continuă!” STATISTICĂ incredibilă şi un MIRACOL [Everybody wants to Dodel, nobody wants to be Nadia! The proof of the CHAOS from the Romanian sport: »The degradation continues!« An incredible STATISTICS and a MIRACLE]. ProSport, 11. 01. 2012, section Sport Life - Special. Retrieved from: http://www.prosport.ro/sport-life/ 
special/toti-vor-sa-fie-dodel-nimeni-nu-mai-vrea-sa-fie-nadia-dovada-haosuluidin-sportul-romanesc-degradarea-continua-statistica-incredibila-si-un-miracol9139212. Downloaded: 2016. 08. 24.

- Furnham, A. (1990). Personality and Demographic Determinants of leisure and Sports preference and Performance. International Journal of Sport Psychology, (21), 218-236.

- Gavriluță, C. \& Gavriluță, N. (2010). Sociologia sportului - Teorii, metode, aplicații [Sociology of Sports - Theories, Methods, Applications]. Iași, Polirom Press.

- Ikulayo, B. P. (1992). Psychological Imposition on Athletes in Competitive Sport. Journal of International Council for Health, Physical Education and Recreation, 28 (4), 27-29.

- Ilieș, A., Dehhoorne, O. \& Kosma, G. (2014). For Geography and Sport, Sport Geography or Geography of Sport. Geosport for Society, 1 (1-2), 7-18. Source: http:// gss.webhost.uoradea.ro. Downloaded: 2016. 08. 25.

- Kaschuba, W. (1989). Sportivitat Die Kariere eines neuen Leit- wertes. Sportwissenchaft, 19 (2), 152-171.

- Lucaciu, Gh., David, L., Lucaciu, S. \& Pop, A. C. (2014). Effects of Mountain Tourism Practice. Analele Universității din Oradea - Fascicula Educație Fizică și Sport [Annals of the University of Oradea - Physical Education and Sport Fascicle], (24), 82-86. Oradea Source: http://www.fefsoradea.ro/Fascicula_Educatie_ Fizica_si_Sport/2014/10.FEFS_2014_Gheorghe.pdf. Downloaded: 2016.08.25.

- Orlick, T. (2008). In Pursuit of Excellence ( $4^{\text {th }}$ ed.). Champaign, IL. Human Kinetics.

- Parlebas, P. (1987). Perspectivas para una educacion fisica moderna. Cuadernos tecnicos Unisport. Malaga, UNISPORT.

- Piaget, J. \& Inhelderova, B. (1970). Pshycologie ditete. Praha, SPN.

- Pop, A. C. (2012). Ways of improving tourism via developing Four Cross competition tracks. Analele Universitäții din Oradea [Annals of University of Oradea], Geography series, 22 (2), 346-351. ISSN 1221-1273. Source: http://geografie-uoradea.ro/ Reviste/Anale/Art/2012-2/AUOG_604_Anca.pdf. Downloaded: 2016. 08.25.

- Robertson, I. (1982). Sport in the Lives of South Australian Children. In Orlick, T., Partington, J. T. \& Salmela, J. H. (Eds.): Mintal Training for Coaches and Athletes (pp. 61-63). Ottawa, Sport in Perspectives.

- Sage, G. H. (1986a). The Effects of Physical Activity on the Social Development of Children. In Stull, G. A. \& Eckert, H. M. (Eds.): Effects of Physical Activity on Children (pp. 22-29). Champaign, Human Kinetics Publ.

- Sage, G. H. (1986b). Social Development. In Seefelft, V. (Ed.): Physical Activity and Wellbeing (pp. 343-372). Reston, AAHPERD.

- Sage, G. H. (1988). Sport, Culture and Society. JOPERD, (34), 40-52.

- Telama, R. (1998). Psychological background of a physically active lifestyle among European youth. In Naul, R., Hardman, K., Pieron, M. \& Skirsted, B. (Eds.): Physical activity and healthy lifestyles of children and youth (pp. 63-74). Schondorf, Karl Hofmann. 
- Thill, E. (1988). Evaluation longitudinale de traits de personnalite de sportifs et de non sportifs. International Journal of Sport Psychology, (19), 107-118.

- Ungerer-Rohrich, U., Singer, R., Hartman, H. \& Kreiter, C. (1988). Social Learning in Physical Education: Concept, Realisation, Evaluation. In Rieder, H. \& Hanke, U. (Eds.): Sportlehrer und Trainer heute. The Physical Education Teacher and Coach Today, Band 2 (pp. 305-310). Köln, Bundesinstitut für Sportwissenschaft.

- Weiss, M. R. \& Bredemeier, B. J. (1986). Moral Development. In Seefeldt, V.(Ed.): Physical Activity and Wellbeing (pp. 373-392). Reston, AAHPERD. 



\title{
III. FEJEZET
}

\author{
A testnevelés és sport \\ helyzete, \\ szerepe a Kárpát-medencében
}





\title{
Közép-kelet-európai hallgatók sportolásának szociokulturális jellemzői
}

\begin{abstract}
Absztrakt
Tanulmányunkban arra vállalkoztunk, hogy bemutassuk Magyarországon az Észak-Alföld régió és a határon túli területek legfontosabb felsőoktatási intézményeiben tanuló hallgatók sportolását meghatározó tényezőket. A kutatásban három magyarországi, három erdélyi és két partiumi, két felvidéki, három kárpátaljai és egy vajdasági intézmény elsősorban magyar hallgatóit vizsgáltuk meg az intézmények létszámával arányos mintát véve ( $\mathrm{N}=2017)$. Összességében azt láthatjuk, hogy a magyarországi, partiumi és erdélyi, vajdasági és felvidéki hallgatók között egyaránt alacsony a rendszeresen sportoló hallgatók aránya, mindenütt a vizsgált régióban átlagosan alig heti rendszerességgel végeznek testedzést a diákok. Ha a sportolást meghatározó társadalmi és individuális tényezőket egy modellben vizsgáljuk, azt láthatjuk, hogy erőteljes nemek közötti és anyagi helyzetben mutatkozó egyenlőtlenségeket tapasztalhatunk Magyarországon, Romániában (itt a leginkább) és Ukrajnában is. A sportolás férfi dominanciája és anyagi lehetőségektől való függősége ezekben a térségekben érvényesül a leginkább. Ha beemeljük a magyarázó modellbe a szubjektív választáson alapuló attitúdökhöz, életmódhoz kapcsolódó elemeket, akkor a nem hatása eltűnik, a szubjektív anyagi, társadalmi helyzet pedig csak a kárpátaljai mintában érvényesül. A legnagyobb, egyébként pozitív hatása a sportolás egészségmegőrzésben fontos szerepet játszó attitűdnek mint motivációs tényezőnek van.
\end{abstract}

\section{Bevezetés $^{1}$}

Kutatásunk célja, hogy feltárjuk, milyen szerepe és jelentősége van a sportnak a magyar, szlovák, ukrán, szerb és román határ menti régió felsőoktatási intézményeiben, a kisebbségi magyar hallgatók közösségeinek életében. Összehasonlító vizsgálatunk során egyrészt arra keressük a választ, hogy milyen jellemzői és formái vannak a sportnak ezen intézményekben, milyen hasonlóságok és különbségek vannak a sportolás meghatározó társadalmi és egyéni tényezőknek a vizsgált régió egyetemein és főiskoláin.

Az Eurobarometer 2014 adatai szerint a magyar lakosság 44\%-a soha nem végez testedzést, ezzel elmaradva az EU-s átlag mögött, s ez a negatív tendencia a szomszédos országokban, sőt egész Közép-Kelet-Európában is érvényesülni látszik (Van Tuyckom \& Schreeder 2010; Pasqui et al. 2009). A kutatás egyik sajátossága, hogy egy

\footnotetext{
1 A tanulmány a Bolyai János Kutatási Ösztöndíj támogatásával készült.
} 
több országot magába ölelő régió hallgatóinak sportolási szokásait vizsgálja, amelyre eddig tudomásunk szerint nem került sor, célul tűzve ki az esetleges különbségek feltárását, de figyelembe veszi, hogy az érintett országok történelme erőteljesen összefonódik. Közös pont a rendszerváltás okozta sokk, mely újfajta társadalmi, gazdasági, politikai berendezkedést vont maga után, átalakítva a különböző alrendszereket, így a sport, az oktatás, s ezen belül a testnevelés oktatásának alrendszerét is. Mindezen folyamatok hatására pedig növekedtek az egyes társadalmi csoportok esélykülönbségei a rendszeres sportolás tekintetében. Ezért fontos feltárni, hogy a vizsgált régió, a Kárpát-medence egészében, s ezen belül a különböző országokban milyen szerep jut a sportolásnak a hallgatói életmódban, s a különböző sportolási szokásokat milyen tényezők befolyásolják. Az egyetemeknek nagy szerepe és felelőssége van a következő értelmiségi - generáció egészségének megőrzésében és javításában az egészségtudatos életmódra való nevelés által, melynek elengedhetetlen része a rendszeres testmozgás.

Az elemzésekhez a Felsőoktatási Kutató és Fejlesztő Intézet (CHERD-H) egy öt országgal határos régió felsőoktatási intézményeinek hallgatóit vizsgáló kérdőives felméréséból származó adatbázisát használtuk fel (IESA - TESSCEE II, N = 2017). ${ }^{2}$ A kutatás során olyan hazai intézményeket választottunk ki, ahol a hallgatók 15 százaléka hátrányos helyzetünek tekinthető a hátrányos helyzetért járó többletpontok igénylése alapján (Hegedûs 2016). E szempont szerint az Észak-Alföldi régió intézményei jelentősen kiemelkednek, s földrajzi helyzetükből adódóan fontosnak tartottuk összehasonlítani ezeket a hallgatókat a régióhoz tartozó, ámde a határokon átnyúló területek határon túli kisebbségi intézményeinek diákjaival. A hallgatói populációval arányos mintát választottunk ki az egyes intézményekből, ezért - érthető módon - a magyarországi alminta nagyobb a határon túli magyar almintáknál.

\section{A sport helyzete és szerepe a közép-kelet-európai fiatalok életében}

A rendszerváltás után a megváltozott gazdasági, politikai és társadalmi körülmények a sport alrendszerét is megváltoztatták a volt szocialista, közép-kelet-európai államokban. Magyarországon a rendszerváltás utáni magyar sportot túlpolitizáltság, recentralizáció és paternalizmus jellemzi. A túlpolitizáltságot jól mutatja, hogy az ezredforduló környékén, s napjainkban ismét, az állami költségvetési támogatás igen magas volt, magasabb, mint bármikor is a szocialista rendszer alatt és után, de ennek a sport különböző szférái közötti elosztását csak és kizárólag politikai indokok határozták meg. A recentralizációt tükrözi, hogy habár a félig civil és félig állami sportszervezeteknek volt joguk arra, hogy érvényesítsék a civilszervezetek véleményét múködésükről, valójában a sportélet szervezésében és irányításában nem vették figye-

2 Az Institutional Efect on Students' Achivement (IESA) és a Teacher Education Students Survey in Central and Eastern Europe (TESSCEE) kutatások a Debreceni Egyetem Felsőoktatási Kutató és Fejlesztő Központja (CHERD-H) koordinálásával valósultak meg. 
lembe véleményüket. A paternalizmust az mutatja, hogy a rendszerváltás óta sem a civil társadalom (ezen belül is az önkéntesség), sem az üzleti szektor (elsősorban a szponzorálás) nem erősödött meg annyira, hogy támogatni tudják a sportegyesületeket mind az élsport, mind a szabadidôsport területén. İgy ezek fennmaradása, múködése és eredményessége a politikai hatalom, a pártok és a vezetố politikusok kezében van. A hatalomnak kell gondoskodni ezekről, rajtuk múlik, hogy a sportszervezetek kellőképpen tudjanak működni, s a sportolók eredményeket tudjanak elérni (Földesi 2009). Szlovákiában sem volt képes megküzdeni a sport társadalmi rendszere a rendszerváltás okozta nehézségekkel: nem volt képes kialakítani egy olyan rugalmas, a kihívásokhoz alkalmazkodni tudó intézményrendszert, amely összefogja és koordinálja az egyes sportágak szövetségeit és hozzákapcsolja ezeket más állami intézményekhez (Leska 2001). Állami támogatás hiányában a sportszervezetek nem érdekeltek abban, hogy minél több gyerekkel, fiatallal foglalkozzanak, amennyiben mégis, sok esetben a szülők állják a költségeket (Antala 2011).

A rendszerváltás után felerősödtek az egyes társadalmi csoportok közötti egyenlőtlenségek, s így bizonyos társadalmi csoportok kirekesztódtek a sportból (is) (Földesiné \& Gáldiné 2008). A társadalmi kirekesztődés a társadalom egészében, így a sportban is összekapcsolódik az (alacsony) szocioökonómiai státusszal és szegénységgel, munkanélküliséggel, alacsony iskolázottsággal, ezáltal hozzájárul a hátrányos társadalmi rétegek mozgásszegény életmódjának kialakulásához és fennmaradásához. Tágabb értelemben a társadalmi kirekesztődés a sportban sokkal több csoportot felölel, s rávilágít az előbb említett csoportokon kívül többek között a nem, a kor, a lakóhely, a fogyatékosság mentén elkülönülő, s hátrányban lévő csoportok sportolásának problémáira, kizárására a rendszeres fizikai aktivitás végzéséből (Földesi Szabó 2010; Gál 2014; Dóczi 2014).

Több hazai és az érintett országokban készített elemzés hívja fel a figyelmet a fiatalok, s ezen belül a hallgatók inaktív életmódjára, s az ebből fakadó, már ebben az életkorban megjelenő problémákra. A romániai Resita Egyetem hallgatóinak több mint egyharmada nem sportol, ami összekapcsolódik azzal, hogy több mint a diákok fele túlsúlyos (Bichescu 2013), a szerbiai Educons Egyetem hallgatóinak pedig 65,5\%-a inaktív, annak ellenére, hogy egyébként fontosnak tartják a sportolás szerepét az egészség megőrzésében. A legkritikusabb korosztály a 21-25 éveseké a vizsgálat szerint (Nesic \& Kovasevic 2011). A magyarországi, szegedi egyetemisták körében végzett vizsgálat is rámutat az inaktív életmód elterjedésére körükben, hiszen csupán 36\%-uk sportol hetente legalább háromszor (Keresztes 2015), de a budapesti egyetemisták körében sem kapunk sokkal jobb eredményeket (37\%), annak ellenére, hogy ez növekvő arányt jelent 2010-re 2004 és 2006-hoz viszonyítva (Szabó 2013). Egy 12 és 18 évesek körében végzett, több országot összehasonlító vizsgálatban a romániai fiatalok 40\%-a, a szlovákok 34\%-a és a magyarok csupán 20\%-a végzett legalább 60 percnyi ajánlott napi fizikai aktivitást (Soós et al. 2014).

A válaszadók többsége az időhiányt jelölte meg a nem sportolás okaként, de szerepet játszanak még a romániai és magyarországi hallgatók körében a nem megfelelő 
anyagi körülmények (Kovács 2014; Bichescu 2013), illetve a nemek között is erőteljes különbségek fedezhetôk fel a sportolás gyakoriságában a férfiak/fiúk javára, főleg a teljesítménysportokban. Bizonyos szabad idôben végzett tevékenységek, mint például a tv-nézés gyakorisága szintén hozzájárul a csökkent fizikai aktivitáshoz, így a szabadidő-eltöltés mintázatainak vizsgálata szintén releváns lehet kutatásunkban is (Szabó 2013; Soós et al. 2014). Ugyanakkor azt is látnunk kell, hogy a magyarországi és romániai hallgatók sportolási szokásaiban meghatározó szerepet játszanak a társas, környezeti és individuális, életmódhoz kapcsolódó tényezők, közösségek is, amelyek képesek felülírni a társadalmi háttérben tapasztalható különbségeket is (Kovács 2015b; Keresztes 2015).

\section{Kutatási kérdések és módszerek}

Kutatásunk során arra kerestük a választ, hogy országonként milyen különbségek vannak a hallgatók sportolásának gyakoriságában, a sportoláshoz kapcsolódó attitûdökben, a nem sportolás okaiban, a preferált sportágakban. Az elemzésekhez a Felsőoktatási Kutató és Fejlesztő Központ legutóbbi, 2014/2015-ös longitudinális vizsgálatának második felméréséból származó adatbázist használtuk fel (IESA - TESSCEE II). A mintavételi keret meghatározása az intézmények adatszolgáltatása alapján történt. Az intézmények és a karok hallgatószámával arányosan alakítottuk ki az elemszámot, ebből kifolyólag természetesen sokkal több magyarországi hallgató van, mint határon túli, ezért az országok közötti összehasonlításnál kapott eredményeket óvatosan kell kezelni, nem általánosíthatók az egyes országok teljes hallgató populációira, csak az adott intézmény, elsősorban magyar nyelvủ diákjaira. Az alapképzés és az osztatlan képzés 2. évfolyamán 20 százalékos, a mesterképzés 1 . évfolyamán és az osztatlan képzés 4. évfolyamán pedig 50 százalékos mintát terveztünk. A diákokat csoportosan, egyetemi/főiskolai kurzusokon kerestük meg. A véletlenszerúség érvényesülését az e csoportok random módon történő kiválasztása biztosította (Pusztai et al. 2016).

Az összehasonlításokat a sportolás gyakorisága, a sportoláshoz kapcsolódó attitűdök, ${ }^{3}$ a nem sportolás okai, a sportos szabadidő-eltöltés ${ }^{4}$ és a sportkörtagság-változók mentén végeztük el. A magyarázó változók közé beemeltük a legfontosabb társadalmi-demográfiai változókat: nem, szülők iskolai végzettsége, lakóhely településtípusa, szubjektív és objektív anyagi helyzet. Az elemzések során megvizsgáltuk az egyes országok hallgatói közötti különbségeket, majd országonként külön-külön néztük meg, hogy mely társadalmi-demográfiai háttérváltozók befolyásolják a hallgatókat a

3 Faktorelemzéssel két attitúdtípust különböztettünk meg. Egészségmegőrző attitûd változói: azért, hogy fitt és egészséges legyen; jól nézzen ki; a stressz leküzdése végett; örömet okoz. A versenyző attitűd változói: azért, hogy versenyeken megmérettesse magát; a győzelem; a sporttársak, közösség miatt. A faktorsúlyokat 0-tól 100-ig tartó skálává kódoltuk át.

${ }^{4}$ A szabadidő-eltöltési szokások mintázatát faktorelemzéssel hoztuk létre. Ez alapján négyféle preferenciát különböztettünk meg: magaskultúra-fogyasztó, társas-bulizós, sportos-játékos és magányos/rekreációs szabadidó-eltöltés. További részletek Kovács (2015a) tanulmányában olvashatók. 
sportolás gyakoriságában, az összes magyarázó változó (szociodemográfiai tényezők, a sportolás fontosságához kapcsolódó attitűdök és szabadidő-eltöltési preferenciák) hatását a sportolás gyakoriságára pedig regresszióval teszteltük a magyarországi, kárpátaljai, felvidéki és partiumi-erdélyi hallgatók esetében. A szerb minta kis elemszáma miatt ezeket az elemzéseket nem tudtuk elvégezni a vajdasági adatokon.

\section{Eredmények}

A hallgatók 22,3 százaléka gyakorlatilag soha nem sportol, legnagyobb arányban $(24,2 \%)$ havonta egyszer-kétszer, heti rendszerességgel is csak $22 \%$, s az egészségmegőrzés szempontjából elegendő alkalommal, tehát legalább háromszor pedig a hallgatók 18\%-a. A leggyakoribb sportágak a klasszikusnak tekinthetó, futás/kocogás, focizás, kerékpározás, kondizás és úszás. Leginkább az egészség megőrzése és a szellemi felfrissülés miatt tartják fontosnak a sportolást (80,4 és 75,3\% válaszolt igennel erre a kérdésre), s legkevésbé fontos a győzelem, a versenyzés és a közösség (12,6, 13,1 és 32\% válaszolt igennel), ami jól mutatja egyrészt a versenysport háttérbe szorulását a hallgatók körében, másrészt a sportolás egyre inkább individuális tevékenységgé válását. A nem megfelelő mennyiségú sportolás indokaként a hallgatók legnagyobb arányban az idő hiányát jelölték meg $(41,7 \%)$, de az anyagi korlátok is erőteljes befolyásoló erővel bírnak (22\%-nak nincs elég pénze a sportolásra), 17,8\%-uk pedig, úgy túnik, nem elégedett az intézménye által nyújtott sportolási lehetőséggel. Ha a sportolás intézményi formáját vizsgáljuk, akkor a hallgatók összesen 19,7\%-a tagja sportklubnak, sportegyesületnek, s 11 százaléka szurkolókörnek. A szabadidő-eltöltési szokásokat vizsgálva is fontos szerep jut a tevékenységek között a futásnak, sétának, kerékpározásnak, ugyanis a hallgatók 53\%-a legalább hetente fut/sétál, egyharmaduk pedig biciklizik, minden ötödik hallgató legalább havonta elmegy kirándulni, túrázni.

A tanulmány további részében bemutatjuk a legfontosabb sportos kérdésekhez kapcsolódó, országok közötti különbségeket. A leggyakrabban a felvidéki és kárpátaljai diákok sportolnak (58,2 és 57 pont), s rájuk jellemző leginkább a sportos-játékos szabadidő-eltöltés, míg a legritkábban a partiumi és erdélyi diákok sportolnak (47,3 pont). Noha szignifikáns különbségeket találunk a sportolás gyakoriságában, azonban ezek nem tekinthetők lényeges eltéréseknek: összességében hazánkban és a határon túli területek hallgatóira viszonylag alacsony, általánosan ritkábban mint a heti rendszerességgel végzett mozgástrend jellemző, ami messze nem éri el az egészség hatékony megőrzéséhez szükséges mennyiséget. A legalább heti háromszor sportoló hallgatók aránya a legmagasabb Magyarországon (20,3\%), ${ }^{5}$ Felvidéken (20\%) és Kár-

5 A sportolás gyakorisága és a legalább hetente sportolók aránya közötti ellentmondás abból fakad a magyarországi hallgatók esetében, hogy noha közöttük találjuk meg a legnagyobb arányban legalább heti három alkalommal testedzést végzóket, ugyanakkor nagyobb arányban vannak közöttük inaktívak is a többi térség diákjaihoz viszonyítva, így ha minden magyarországi válaszadó sportolási gyakoriságát nézzük, akkor összességében átlagosan ritkább sportolási gyakoriságot kapunk. 
pátalján (16,8\%), a legalacsonyabb pedig a partiumiak-erdélyiek $(11,5 \%)$ és vajdaságiak $(11,1 \%)$ körében.

A versenyzés, a győzelem mint motivációs tényezők is szintén a kárpátaljai diákokat jellemzi a leginkább, ez pedig összhangban van azzal, hogy közöttük találjuk a legtöbb sportklubtagot is, ami inkább valószínűsíti a versenyszerű sportolást. Az egészségmegőrzés miatti sportolás viszont a legkevésbé jellemző az ukrajnai hallgatókra, míg a vajdasági és felvidéki diákok számára a leginkább fontos a sportolás egészségvédő funkciója. Ha a nem megfelelő mennyiségű sportolás okait vizsgáljuk, három ok mentén találhatunk szignifikáns különbséget az egyes országok hallgatói között. Az erdélyipartiumi és felvidéki diákok között találhatunk a legmagasabb arányban elégedetlen diákokat az intézmény sportinfrastrukturális lehetőségeivel, míg a vajdaságiak között vannak a legkevesebben. Kiemelkedően magas, majd minden ötödik kárpátaljai hallgató nyilatkozott úgy, hogy egészségi állapota nem engedi, hogy rendszeresen sportoljon, ami nagyon magas aránynak tekinthető ebben a korcsoportban, s szintén ők a legelégedetlenebbek a város által nyújtott sportolási lehetőségekkel (1. táblázat).

1. táblázat. A sportoláshoz kapcsolódó, szignifikáns különbségeket mutató változók országonkénti összehasonlítása (pontok, százalék)

\begin{tabular}{|l|c|c|c|c|c|c|}
\hline & $\begin{array}{c}\text { Magyar- } \\
\text { ország }\end{array}$ & Románia & Ukrajna & Szerbia & Szlovákia & N \\
\hline $\begin{array}{l}\text { Sportolás gyakori- } \\
\text { sága (0-100) }\end{array}$ & 56,7 & 47,3 & 57,6 & 51,1 & 58,2 & 1878 \\
\hline $\begin{array}{l}\text { Versenyző attitűd } \\
\text { (0-100) }\end{array}$ & 18,9 & 14,6 & 25,6 & 23,6 & 15,8 & 2013 \\
\hline $\begin{array}{l}\text { Egészségmegórző } \\
\text { attitüd (0-100) }\end{array}$ & 70,2 & 70,6 & 69,1 & 81,9 & 77,5 & 2013 \\
\hline $\begin{array}{l}\text { Sportos szabadidő- } \\
\text { eltöltés (0-100) }\end{array}$ & 28 & 28,7 & 32,6 & 19,1 & 30,2 & 1982 \\
\hline Tagja sportklubnak & $17,6 \%$ & $16,2 \%$ & $\underline{\mathbf{3 4 , 5 \%}}$ & $22,2 \%$ & $19,1 \%$ & 1857 \\
\hline $\begin{array}{l}\text { Nincs megfelelő } \\
\text { sportolási lehető- } \\
\text { ség az egyetemen }\end{array}$ & $13,1 \%$ & $\underline{\mathbf{2 7 , 6} \%}$ & $\underline{\mathbf{2 4 , 7 \%}}$ & $14,3 \%$ & $\underline{\mathbf{2 6 , 5} \%}$ & 2013 \\
\hline $\begin{array}{l}\text { Nincs megfeleló } \\
\text { sportolási lehetó- } \\
\text { ség a városban }\end{array}$ & $10,3 \%$ & $9,6 \%$ & $\underline{\mathbf{1 9 , 7 \%}}$ & $15,9 \%$ & $15,4 \%$ & 2013 \\
\hline $\begin{array}{l}\text { Egészségi állapota } \\
\text { nem engedi } \\
\text { a sportolást }\end{array}$ & $9,2 \%$ & $6,5 \%$ & $\underline{\mathbf{1 7 , 2 \%}}$ & $1,6 \%$ & $8 \%$ & 2013 \\
\hline
\end{tabular}

Forrás: IESA-TESSCEE 2015.*

* A kiemelve közölt értékek arra utalnak, hogy a táblázat azon cellájába jóval többen kerültek, mint amennyi véletlen elrendeződés esetén várható lett volna. 


\section{A társadalmi háttér szerepe a sportolás gyakoriságában}

A továbbiakban arra keressük a választ, hogy miként befolyásolják társadalmi-demográfiai háttérváltozók azt, hogy az egyes országokban milyen gyakran sportolnak a hallgatók. Terjedelmi korlátok miatt ebben a tanulmányban csak a sportolás gyakoriságára ható tényezőket vesszük górcső alá. A szerb és szlovák almintában nem találtunk szignifikáns összefüggéseket, ennek hátterében a túl kicsi elemszám áll. Egyetlen változó mentén találtunk szignifikáns különbséget minden országban, ez pedig a nem. Korábbi kutatási eredményekkel összhangban ismét igazolódott, hogy a férfiak többet sportolnak, mint a nők (Perényi 2011; 2013; Gál 2014; Kovács 2013; 2015b; 2015c). Úgy túnik, hogy a sportolás még mindig egy olyan maszkulinitáshoz tartozó tevékenység, ami a nőket kevésbé vonzza annak ellenére, hogy vizsgálatunk és más kutatási eredmények is igazolják, rájuk inkább jellemző az egészségtudatosság, s a sportolás egészségmegőrző szerepe is fontosabb számukra, mint a férfiak számára (Bollók et al. 2011). Ennek s a számtalan médiakampány ellenére, mely folyamatosan sulykolja belénk, hogy milyen fontos a rendszeres testmozgás számos betegség megelőzésében és az egészség hatékony megőrzésében, a nemek közötti egyenlőtlenségek noha átalakulnak, új területek jelennek meg, de továbbra is fennállnak (Gál \& Gáldi 2015). Szintén szignifikáns befolyásoló ereje van az anyagi helyzetnek a magyar és a román hallgatók körében: minél jobb anyagi helyzetben van egy hallgató (objektíven és szubjektíven mérve), annál gyakrabban sportol. Különösen nagy a gazdasági tőke szerepe a romániai hallgatók esetében. Az ő körükben sokkal nagyobbak a különbségek az egyes csoportok között, s mintegy tíz ponttal alacsonyabb értékeket érnek el a sportolás gyakoriságát tekintve az azonos kategóriába tartozó magyarországi társaikhoz viszonyítva. A magyarországi almintában a magukat legrosszabb helyzetbe soroló hallgatók viszonylag magas pontszáma a kicsi (17 fố) elemszám torzító hatásával magyarázható, a többi kategóriában viszont érvényesülni látszik az általános trend (2. táblázat).

2. táblázat. A sportolás gyakoriságának szignifikáns különbségei a szociokulturális háttér mentén a magyarországi, partiumi és erdélyi, illetve kárpátaljai intézményekben

\begin{tabular}{|c|c|c|c|c|c|c|c|}
\hline & & $\mathrm{HU}$ & $\mathrm{n}$ & RO & $\mathrm{n}$ & UA & $\mathbf{n}$ \\
\hline \multirow{2}{*}{ Nem } & Nő & $55,1^{*}$ & \multirow{2}{*}{1077} & $44,9^{*}$ & \multirow{2}{*}{310} & $54,1^{*}$ & \multirow{2}{*}{228} \\
\hline & Férfi & $59,5^{*}$ & & $56,8^{*}$ & & $67,4^{*}$ & \\
\hline \multirow{2}{*}{$\begin{array}{l}\text { Objektív } \\
\text { anyagi helyzet }\end{array}$} & Átlag alatt & $53^{*}$ & \multirow{2}{*}{1109} & $42,7^{*}$ & \multirow{2}{*}{314} & 56 & \multirow{2}{*}{232} \\
\hline & Átlag felett & $59,1^{*}$ & & $50,6^{*}$ & & 59,6 & \\
\hline \multirow{4}{*}{$\begin{array}{l}\text { Szubjektív } \\
\text { anyagi helyzet }\end{array}$} & Mindenünk megvan & $61,9^{*}$ & \multirow{4}{*}{1050} & 50,3 & \multirow{4}{*}{304} & 59,2 & \multirow{4}{*}{219} \\
\hline & $\begin{array}{l}\text { Nagyobb kiadásokra } \\
\text { nem telik }\end{array}$ & $55,4^{*}$ & & 46,1 & & 55,8 & \\
\hline & $\begin{array}{l}\text { Előfordulnak anyagi } \\
\text { gondok }\end{array}$ & $49,5^{*}$ & & 45,7 & & 57,3 & \\
\hline & $\begin{array}{l}\text { Gyakran } \\
\text { vannak anyagi gondok }\end{array}$ & $60^{*}$ & & 40 & & 80 & \\
\hline
\end{tabular}

Forrás: IESA - TESSCEE 2015 
Jól igazolja a felsőoktatási intézmények elsősorban kulturális egyenlőtlenségeket nivelláló hatását az a tény, hogy sem a szülők iskolai végzettségének mint kulturális tőkének, sem a lakóhely településtípusának nincs szerepe abban, hogy egy hallgató milyen gyakorisággal sportol. Előbbi esetben az oktatási intézmények formális és informális tudásátadó és információnyújtó tevékenysége, funkciója játszik szerepet. A település szerinti egyenlőtlenségek feloldását pedig az egyetemi város és a felsőoktatási intézmények infrastrukturális lehetőségei adják (Fábri 2002).

A továbbiakban lineáris regressziót alkalmazunk annak meghatározására, hogy az egyes társadalmi háttérváltozók és az olyan szubjektív, egyéni magyarázó tényezők, mint a sportolás iránti attitűdök és a sportos szabadidő-eltöltés, miként befolyásolja a sportolás gyakoriságát országonként, ha ezen magyarázó változók hatását egy modellben elemezzük. Ebben az esetben is a vajdasági mintán történő elemzést nem végeztük el a kis elemszám miatt. Az eredmények azt mutatják, hogy ha bevonjuk az elemzésbe a szubjektív tényezőket, akkor ezek képesek felülírni a társadalmi háttérváltozók hatását: a nem és az objektív anyagi helyzet nem befolyásolja a hallgatók sportolásának gyakoriságát egy országban sem, a szubjektív anyagi helyzet pedig egyedül a kárpátaljaiak esetében bír hatással. Ez utóbbi hátterében fontos szerepet játszhat az elmúlt években érezhető, a kelet-ukrajnai háborús konfliktusnak (is) köszönhető gazdasági recesszió, amelynek következtében az ország gazdasági helyzete jelentősen romlott, az ukrán hrivnya pedig jelentősen inflálódott. Ez a helyzet pedig jelentősen rontotta a lakosság életminőségét, szubjektív jólétét és még jobban látványossá tette a gazdagok és a szegényebbek közötti különbségeket, fokozta a csekély közép- és nagyszámú alsó osztálybeliek frusztrációját. Ilyen körülmények között pedig a jelentős arányú hátrányos helyzetű hallgatók sem tudják vállalni a sportoláshoz kapcsolódó esetleges költségeket.

Az egészségmegőrző sportolási attitűd az a tényező, amely minden esetben pozitívan járul hozzá a rendszeres sportoláshoz: minél inkább tudatosul a diákokban a sportolás fontossága az egészség megőrzésében - országtól függetlenül-, annál inkább lesz motiváltabb a hallgató a rendszeres testedzést illetően. A versenyző sportattitűdnek szintén pozitív hatása van, de csak a magyarországi hallgatók esetében. A versenyzés és győzelem fontossága elsősorban az élsportolóknak lehet fontos, vagy akik versenyeken mérettetik meg magukat, a megfelelő teljesítmény és minél jobb eredmény eléréséhez pedig természetesen elengedhetetlenek a rendszeres edzések.

A sportos-játékos tevékenységekkel jellemezhető szabadidő-eltöltési preferencia is pozitívan járul hozzá a sportoláshoz a magyarországi, partiumi és erdélyi, a futást is magában foglaló rekreációs tevékenységek pedig szintén az előbbi hallgatók esetében. Azon diákok, akik szívesen töltik fizikailag aktívan, vagy társas játékokkal szabad idejüket, ezzel edzve testüket, szellemüket (futással, kirándulással, túrázással, csapat- vagy egyéni sportjátékokkal, társas játékokkal), számukra ezek a tevékenységek hozzájárulnak ahhoz, hogy minél rendszeresebben végezzenek testmozgást. Ugyanakkor az összefüggés fordítva is érvényesülhet: azok számára, akiknek életében fontos szerepet játszik a sportolás, szívesebben tölthetik szabad idejüket is rekreációs jelleggel végzett 
fizikai aktivitással, társas játékokkal. Ugyanakkor azt is láthatjuk a magyarországi diákok esetében, hogy habár a magaskultúrához kapcsolódó tevékenységek kevésbé jellemzik a fiatalok szabadidő-eltöltését, azonban ezek preferálása csökkenti a sportolás gyakoriságát. A regressziós elemzések eredményeit az alábbi, 3. táblázat közli.

3. táblázat. A társadalmi háttérváltozók, a sportolás fontosságához kapcsolódó attitűdök és a sportos-játékos szabadidő-eltöltés hatása a sportolás gyakoriságára országonként

(béta regressziós együtthatók)

\begin{tabular}{|c|c|c|c|c|}
\hline & $\begin{array}{c}\text { Magyar- } \\
\text { ország }\end{array}$ & Románia & Ukrajna & Szlovákia \\
\hline Nem (0 nő, 1 férfi) &, 021 & ,087 &, 042 & ,144 \\
\hline Objektív anyagi helyzet (0-100 pont) &, 025 &,- 013 &,- 007 & ,212 \\
\hline Szubjektív anyagi helyzet ( $0-80$ pont $)$ &, 005 &,- 031 &, $147^{*}$ &,- 141 \\
\hline Lakóhely településtípusa (0 vidék, 1 város) &, 045 &, 008 &,- 022 &, 115 \\
\hline Szülők iskolai végzettsége osztályokban & ,032 &, 008 &,- 011 &, 131 \\
\hline Magaskultúra-fogyasztó szabadidő-eltöltés &,$- 093^{* *}$ &,- 116 &,- 137 &,- 179 \\
\hline Társas-bulizós szabadidő-eltöltés &,- 007 &,- 018 & ,009 &,- 040 \\
\hline Sportos-játékos szabadidő-eltöltés (0-100 pont) &, $195^{* * *}$ &, $272^{* * *}$ & 109 &, 163 \\
\hline Magányos/rekreációs szabadidő-eltöltés &, $103^{* * * *}$ &, 042 &,- 014 &, 153 \\
\hline Versenyző sportattitűd (0-100 pont) &, $130^{* * * *}$ &, 100 &,- 009 & ,123 \\
\hline Egészségmegőrző sportattitűd (0-100 pont) &, $381^{* * * *}$ &, $342^{* * *}$ &, $506^{* * *}$ &, $337^{*}$ \\
\hline $\mathrm{R}^{2}$ & ,304 & ,298 & ,308 & ,384 \\
\hline
\end{tabular}

\section{Összegzés}

Tanulmányunkban arra vállalkoztunk, hogy bemutassuk Magyarországon az ÉszakAlföld régió és a határon túli területek legfontosabb felsőoktatási intézményeiben tanuló hallgatók sportolását meghatározó tényezőket. A kutatásban három magyarországi, három erdélyi és két partiumi, két felvidéki, három kárpátaljai és egy vajdasági intézmény elsősorban magyar hallgatóit vizsgáltuk meg az intézmények létszámával arányos mintát véve $(\mathrm{N}=2017)$. A vizsgált régió sajtossága, hogy egyrészt igen magas a hátrányos helyzetű diákok aránya az egyes intézményekben, másrészt pedig a közös történelmi és kulturális gyökereknek köszönhetően a határon túli intézményekben magas arányban tanulnak magyar diákok, mivel ezek a határon túli magyar kisebbségek fennmaradásának és az értelmiségnevelés kiemelkedően fontos bástyái.

Összességében azt láthatjuk, hogy a magyarországi, partiumi és erdélyi, vajdasági és felvidéki hallgatók között egyaránt alacsony a rendszeresen sportoló hallgatók aránya, mindenütt a vizsgált régióban átlagosan alig heti rendszerességgel végeznek 
testedzést a diákok. Ez pedig komoly problémát vetít előre, amelynek megoldásában fontos szerep jut a felsőoktatási intézményeknek, hiszen jól láthatjuk a nemzetközi statisztikában, hogy a kor előrehaladtával, illetve a tanulmányok befejeztével drasztikusan csökken a rendszeresen sportolók aránya (Dóczi 2014; Perényi 2011; 2013; Kovács 2016). Tovább erősíti az egyetemek/főiskolák felelősségvállalását az a tény, hogy eredményeink szerint az intézmények által nyújtott sportolási lehetőségek, programok, képzések képesek nivellálni a kulturális és településtípus szerinti hátrányból fakadó egyenlőtlenségeket, de ehhez szükséges az is, hogy a hallgatók elégedettek legyenek ezekkel a lehetőségekkel. $\mathrm{E}$ téren a hallgatók értékelése alapján a kárpátaljai, erdélyi és partiumi, illetve felvidéki intézményekben van még teendő. A kárpátaljai intézményekben kiemelkedően magas még az egészségügyi problémákkal küzdő, s emiatt nem sportolható hallgatók aránya, így számukra a gyógytornához kapcsolódó mozgásformák biztosítására is külön figyelmet kellene szentelni.

Ha a sportolást meghatározó társadalmi és individuális tényezőket egy modellben vizsgáljuk, azt láthatjuk, hogy erőteljes nemek közötti és anyagi helyzetben mutatkozó egyenlőtlenségeket tapasztalhatunk Magyarországon, Romániában (itt a leginkább) és Ukrajnában is. A sportolás férfi dominanciája és anyagi lehetőségekhez való erőteljes kapcsolódása ezekben a térségekben érvényesül a leginkább, azonban, ha beemeljük a magyarázó modellbe a szubjektív választáson alapuló attitúdökhöz, életmódhoz kapcsolódó elemeket, akkor a nem hatása eltúnik, a szubjektív anyagi, társadalmi helyzet pedig csak a kárpátaljai mintában érvényesül. Ez utóbbi eredmény felhívja a figyelmet arra, hogy a kárpátaljai diákok esetében különösen fontos szerep jut a társadalmi háttérnek a sportolás gyakoriságában, s ezt nem képesek felülírni az intézmények adta sportolási lehetôségek sem. Ugyanakkor a legnagyobb befolyásoló erôvel a sportolás egészségmegőrzéséhez, s a magyar minta esetében a győzelem, versenyzés fontosságához kapcsolódó attitűd bír: minél fontosabbak ezek az egyének számára, annál inkább motiváltabbak a rendszeres testedzés végzésére. Ily módon minél inkább tudjuk erősíteni a sportolás egészségmegőrzésben játszó fontos szerepét a hallgatók értékrendjében, annál több hallgatót lehetne meggyőzni a sportolásba való bekapcsolódásba társadalmi háttértôl függetlenül. Hasonlóan pozitív eredményt lehet elérni, ha előbb sportos, játékos programokban vesznek részt, ezzel töltve a szabad idejüket, mert az ilyen rekreációs céllal végzett mozgásos tevékenységek olyan élményeket nyújthatnak, amelyek hatására a sportolás beépülhet a mindennapos, vagy legalábbis a rendszeresen végzett tevékenységek közé.

Kutatási eredményeinket nem lehet általánosítani az egyes országok fiatal lakosságára, sôt a hallgatóira sem, hiszen egyrészt eltérő mintákat vettünk, mivel eltérő hallgatói populációval bírnak az egyes intézmények, s főként a magyar hallgatókra és intézményekre fókuszáltunk a kérdőíves felmérés során, azonban a kapott eredményekből jól láthatók a régió hallgatóit jellemző közös vonások, problémák a sportoláshoz kapcsolódóan, s az egyes térség diákjait érintő sajátosságok. 


\section{Hivatkozott irodalom}

- Bollók S., Takács J., Kalmár Zs. \& Dobay B. (2011). External and internal sport motivations of young adults. Biomedical Human Kinetics, (3), 101-105.

- Branislav, A. (2011). School Physical Education Yesterday an Today - Comparison of Some indicators in 1990 and 2010. In Milanovic, D. \& Sporis, G. (eds.): $6^{\text {th }}$ International Scientific Conference on Kinesiology (pp. 24-30). Integrative Power of Kinesiology. Zagreb, University of Zagreb.

- Bichescu, A. (2014). Leisure time sport activities of the students at Resita University. Procedia - Social and Behavioral Sciences, (117), 735-740.

- Dóczi T. (2014). Sport és hátrányos helyzet. In Dr. Gál A.,dr. Dóczi T. \& Sáringerné dr. Szilárd Zs. (szerk.): Társadalmi befogadás a sportban és a sport által (szociális inklúzió) (pp. 37-92). Budapest, Magyar Sportmenedzsment Társaság, Magyar Sporttudományi Társaság.

- European Commission (2014). Special Eurobarometer 412: Sport and Physical Activity.

- Fábri I. (2002). A sport, mint a fiatal korosztályok életmódjának meghatározó eleme. In Bauer B., Szabó A. \& Laki L. (szerk.): Iffúság 2000 Tanulmányok I. (pp. 159-171). Budapest, Nemzeti Ifjúságkutató Intézet.

- Földesi Szabó Gy. (2009). Class or Mass: Sport (for All) Politics at a Crossroads. Physical Culture and Sport Studies and Research, (46), 147-156.

- Földesi Szabó Gy. (2010). Social Exclusion/Inclusion in the Context of Hungarian Sport. Physical Culture and Sport Studies and Research, (50), 44-59.

- Földesiné Szabó Gy. \& Gáldiné Gál A. (2008). Válaszút előtt a sportpolitika. $M a-$ gyar Sporttudományi Szemle, (9), 4-10.

- Gál A. (2014). A nők sportjának jellegzetességei. In Dr. Gál A, dr. Dóczi T. \& Sáringerné dr. Szilárd Zs (szerk.): Társadalmi befogadás a sportban és a sport által (szociális inklúzió) (pp. 7-36). Budapest, Magyar Sportmenedzsment Társaság, Magyar Sporttudományi Társaság.

- Gál A. \& Gáldi G. (2015). Szabadidő-eltöltés és társadalmi nem. In Gál A. \& Dóczi T. (szerk.): Gyöngy(i)szemek. Ajándékkötet Földesiné Dr. Szabó Gyöngyi 75. Születésnapjára (pp. 112-130). Budapest, Testnevelési Egyetem.

- Hegedűs R. (2016). Számok-arányok-mintázatok a felsöoktatásba felvett hátrányos belyzetúek esetében. Modern Geográfia, (3), 1-14.

- Keresztes N. (2015). Egyetemista fiatalok sportolási szokásai és szociális képzetei a rendszeresen sportoló kortársaikról. Magyar Sporttudományi Szemle, 16 (1), 4-14.

- Kovács K. (2013). Bourdieu, Hradil és Bandura elméleteinek vizsgálata a sportra vonatkozóan. A társadalmi, környezeti és egyéni tényezők hatása a partiumi régió hallgatóinak sportolására. Társadalomkutatás, (2), 175-193.

- Kovács K. (2015a). Teacher education Students' Leisure Activities and State of Health. In Pusztai, G. \& Ceglédi, T. (eds.): Professional calling in higher education (pp. 129-138). Nagyvárad-Debrecen, Partium Press, Persional Problems Solution, Új Mandátum Kiadó. 
- Kovács K. (2015b). A sportolás mint támogató faktor a felsőoktatásban. Oktatáskutatók könyvtára 2. Debrecen, CHERD-H (ISBN: 978-963-473-810-7).

- Kovács K. (2015c). Magyarországi és romániai hallgatók sportolási szokásait meghatározó szociokulturális tényezők. In Kozma T., Kiss V. Á., Jancsák Cs. \& Kéri K. (szerk.): Tanárképzés és oktatáskutatás (pp. 673-685). Debrecen, Magyar Nevelés- és Oktatáskutatók Egyesülete.

- Kovács K. (2016). Szabadidő-eltöltés és sportolás a nyíregyházi fiatalok körében. Acta Medicinae et Sociologica, 7 (20-21), 112-130.

- Leska, D. (2001). Culture - Sport - Politics during the period of society transformation int he Slovak Republic. Gymnastica, 31 (2), 9-12.

- Nesic, M. \& Kovasevic, J. (2011). Life habits of student population as a factor in orientation to the university. Acta Kinesiologica, (2), 89-95.

- Pasqui, F., Baldini, M., Lorenzini, A., Bordini, A., Malaguti, M., Di Carlo, M., Miroi, R. \& Maranesi, M. (2009). Evaluation of some nutritional and sport aspects in sedentary and active adolescents: analysis in Italian and Romanian school. Progress in nutrition, 11 (1), 47-56.

- Perényi Sz. (2011). Sportolási szokások - Sportolási esélyek és változástrendek. In Bauer B. \& Szabó A. (szerk.): Arctalan (?) nemzedék. Ifúság 2000-2010 (pp. 159184). Budapest, Nemzeti Család- és Szociálpolitikai Intézet.

- Perényi Sz. (2013). Alacsonyan stagnáló mozgástrend: a fizikai inaktivitás újratermelődése. In Székely L. (szerk.): Magyar Iffúság 2012 (pp. 229-249). Budapest, Kutatópont.

- Pusztai G., Bocsi V. \& Ceglédi T. (2016). A felsőoktatás hozzáadott értéke és a probléma vizsgálatának közelítései közép-európai kontextusban. In Pusztai G., Bocsi V. \& Ceglédi T. (szerk.): A felsöoktatás (bozzáadott) értéke. Közelitések az intézményi hozzájárulás empirikus megragadásához (pp. 7-12). Nagyvárad-Debrecen, Partium Press, Persional Problems Solution, Új Mandátum Kiadó.

- Soos I., Biddle, S. J. H., Ling, J., Hamar, P., Sandor, I., Boros-Balint, I., Szabo, P. \& Simonek, J. (2014). Physical Activity, sedentary behavior, use of electric media, and snacking among youth: an international study. Kinesiology, 46 (2), 155-163.

- Szabó Â. (2013). Mi történt 2004 és 2010 között a budapesti egyetemisták szabadidôsport-fogyasztásában? BCE Múhelytanulmány. Budapest, Vállalatgazdaságtan Intézet. Forrás: http://edok.lib.uni-corvinus.hu/478/1/Szabo_154.pdf. Utolsó látogatás: 2016. 05.16.

- Van Tuyckom, C. \& Schreeder,J. (2010). A multilevel analysis of social stratification patterns of leisure-time physical activity among Europeans. Science and Sports, (25), 304-311. 


\title{
A budapesti egyetemisták sportolási szokásai - 2004-2014
}

\begin{abstract}
Absztrakt
Tanulmányunk célja bemutatni a budapesti egyetemisták szabadidő-eltöltését és sportolási szokásait, négy kutatás alapján. A Bíbor Béka civil kezdeményezés által készített online 2014-es kutatás célja az volt, hogy felmérjük a budapesti egyetemisták szabadidő-eltöltését, sportfogyasztását, mi motiválja őket a sportolásra, és milyen sportágakat választanak, megismételve, valamint kiegészítve Szabó 2010-es hasonló kutatását, amelyet 2004-ben és 2006-ban is elvégzett. Az eredmények bemutatása előtt releváns nemzetközi és hazai kutatásokat is bemutatunk. Eredményeink szerint a sportolás mint szabadidős tevékenység a 10 évet vizsgálva egyre fontosabbá vált, megkérdezettjeink főbb motivációi, a szekunder forrásokkal megegyezően, az egészségre, fittségre törekvés, illetve az attraktív külső kialakítása. Előtérbe kerültek azok az egyéni sportok (futás, kondi, aerobik), amelyek nem igényelnek komolyabb előképzettséget és a közelben űzhetőek. Az eredmények ugyanakkor sportáganként és nemenként eltérőek. Kutatási eredményeinket felhasználva relevánsabbá tehető az egyetemisták számára a sportkínálat mind egyetemi, mind egyesületi, vagy akár az üzleti vállalkozások szintjén.
\end{abstract}

\section{Bevezetés, elméleti háttér}

Tanulmányunk a budapesti egyetemisták sportolási szokásait veszi górcső alá, vizsgálva azt, hogy miért sportolnak, hogyan választottak sportágat, mit sportolnak, hol sportolnak, mennyit költenek szabadidősportra négy kutatás alapján, a 2004 és 2014 közötti időszakot áttekintve. A tanulmányban a motiváció a leghangsúlyosabb elem. A kutatási eredmények főbb pontjairól rövid áttekintést adtunk a Magyar Sporttudományi Szemlében (Kozma et al. 2015). Jelen tanulmányunk ennél részletesebb, átfogóbb, a korábbi évek kutatásait mélyebben bemutató összegzés. Az összehasonlítás, a 10 év változásainak leírása jelen tanulmányunk egyik fó célja.

A legtöbb kutatás szerint a férfiak, a fiatalabbak, a magasabb jövedelmúek, a nagyobb településen lakók és a képzettebbek többet sportolnak (Polányi 1998; Neulinger 2007; Gál 2008; Eurobarometer 2010; 2014; Paár 2013; Gál 2014; Kovács 2013; 2015a; 2015b). Ugyanakkor a fiatalok csoportján belül is jelentős különbségek mutatkoznak: az Ifjúság 2000, 2004, 2008 és 2012 kutatások (Laki et al. 2001; Bauer \& Szabó 2005; Szabó \& Bauer 2009; Perényi 2013) és Gáldi kutatásai is ezt bizonyítják. A fiatalok között is az életkor előrehaladtával szintén csökken a rendszeresen mozgók 
aránya; minél magasabb státuszú oktatási intézménybe jár valaki, annál valószínúbb, hogy rendszeresen sportol; a magasabb státuszú településtípus nagyobb eséllyel jelent nagyobb arányú sportolási részvételt. 2004-ről 2008-ra és 2008-ról 2012-re csökkent a sportolási arány a fiatalok körében (Perényi 2010; 2013). Gáldi (2004) kutatásai szerint a 20 év alattiak és a 20-29 évesek között is nagy különbség tapasztalható a sportolási hajlandóságban, mert míg a 20 év alattiak 67,4\%-a, a 20-29 évesek fele számolt be valamilyen rendszerességú testmozgásról. A Debreceni Egyetem Campus-lét 2010-es 4189 fős online kutatásából az derült ki, hogy internetezni, zenét hallgatni és tv-t nézni szeretnek leginkább a debreceni egyetemisták, és mindössze 19\%-uk mozog hetente többször is (Kovács 2011).

A szabadidősport-fogyasztás előfeltételei lehetnek: a megfelelő mennyiségú szabadon felhasználható idő, a megfelelő életszínvonal, pénz és a megfelelő szemlélet (Budai 1999; Laki \& Nyerges 2004). A megfelelő szemlélet a legfontosabb tényező a szabadidősport-fogyasztása esetében, amit sokkal nehezebb operacionalizálni és mérni, mint az idő- vagy a pénzfaktort. Pataki (2007) a magyar fiatalok sportolásáról írt munkájában szintén ezen tényezőket vizsgálta, és azt állapította meg, hogy a szemléletmód közvetlenül hat az aktív szabadidős sportfogyasztásra való hajlandóságra, a pénz csak közvetetten hat rá. A fizikai inaktivitás nem magyarázható közvetlenül a szabad idő hiányával sem.

Nemzetközi kutatások szerint a fiatalok sportolásához pszichológiai igényeik, az önmegvalósítás, társas igényeik (barátokkal együtt lenni, népszerủség a kortársak körében) és a kívánt élettani hatások elérése (nagyobb izomerő) fejtenek ki jelentős motiváló erőtt (Goudas et al. 1994). Neulinger (2007) magyar egyetemisták körében végzett 1000 fős kvantitatív, 80 esszét feldolgozó és 12 mélyinterjús vizsgálatai szerint is a kortársak és a barátok szerepe a legjelentősebb a sportolásban való részvételkor, azaz a barátok sportolását találta a legerősebben összefüggőnek az egyén sportolásával. A fiatalabbak az idősebbekkel ellentétben sokkal fogékonyabbak a külső ingerekre, a barátok „unszolására”, amelyek testmozgásra mozgósítják ôket. Ezen eredmények némileg ellentmondanak Laki és Nyerges 1997-es kutatási eredményeinek, melyek szerint, főleg a fôvvárosban, ahol az aerobik, a fitnesz, a testépítés, a kerékpár, a kocogás és az úszás a fiatalok kedvence, a sportolás individualizálódott. A fiatalok esetében ugyanis a mozgás és a barátok összekapcsolódnak, a sport gyakoriságának növekedésével szignifikánsan nő a barátokkal töltött idő (Pluhár et al. 2003).

Az Ifjúság kutatások szerint a sportolásra motiváló két fố tényező mindkét nemnél az, hogy fittek-edzettek és egészségesek legyenek. Székely (2014) szerint a fő motiválók az egészség és az öröm, hogy jól érezzék magukat, és a futás/kocogás/túrázás, valamint az aerobik a legnépszerúbb sportágak az egyetemisták körében a 2011-ben 16503 fó online megkérdezése, valamint a 2013-ban 1500 fős reprezentatív kutatása alapján. 2013-ban a Magyar Sporttudományi Társaság 300 győri és veszprémi egyetemistát kérdezett meg, a Mozgásgyógyszer program keretében (Szmodis et al.2013). A fizikai aktivitás motivációját tekintve a férfiaknál az állóképesség fejlesztése, a nőknél a fizikai megjelenés volt a legfontosabb szempont. Az egészség megőrzése har- 
madik helyen szerepelt mindkét nemnél. A megkérdezettek közel 14\%-a gyermekkorában rendszeresen nem sportolt és $20 \%$-uk a rendszeres testmozgást három évnél rövidebb ideig végezte. A sportolással töltött idő egyik nemnél sem érte el az átlagos heti két órát, hatoduk nem mozog fél órát sem hetente. Egy 2014-es kutatás szerint a 15-29 évesek legnagyobb arányban említett motivációs tényezői az egészségvédelem, a fizikai teljesítőképesség növelése, a fittség magasabb szintre emelése, illetve a kikapcsolódás. A nőknél fontosabb, hogy kontrollálják testsúlyukat, jobban nézzenek ki és ellensúlyozzák az öregedés hatását, míg a férfiaknál a szórakozás, a barátokkal való együttlét, a képességfejlesztés és a versengés (Gál 2014). A fiatalok motiváló tényezőit tekintve összefoglalva azt állapíthatjuk meg, hogy a fittség és az egészség valamennyi kutatásban fontos volt, ezeket egészítette ki a jó alak elérése, az öröm, kikapcsolódás és a barátokkal való együttlét.

\section{Anyag és módszer}

A tanulmányunk alapját képező 2014-es empirikus kutatás egy online kérdőíves vizsgálat volt budapesti hallgatók körében, amelyet a Bíbor Béka, a testmozgást, egészségtudatosságot és környezettudatosságot ösztönző civil kezdeményezés munkatársai készítettek el a Budapesti Corvinus Egyetemmel együttmúködésben (Bíbor Béka 2014). Az online kérdőíves véletlen mintás megkérdezésre 3374 válasz érkezett Budapest húsznál több intézményéből, ezen belül mind a négy nagy egyetemrôl BME, Corvinus, ELTE, SE - ötszáznál több kitöltött kérdőív gyưlt össze. A kutatás nem reprezentatív. Az online kérdőíves kutatást egészítette ki 23 mélyinterjú budapesti egyetemistákkal, amelyek további betekintést engedtek a hallgatók mozgással kapcsolatos gondolkodásába. A kérdőívet kitöltött hallgatók a sportolási gyakoriságra adott válaszaik alapján három kategóriába oszlottak: (1) rendszeresen sportolók, akik hetente legalább háromszor sportolnak; (2) mérsékelten aktív sportolók, akik - saját bevallásuk szerint - hetente átlagosan egy vagy két alkalommal sportolnak; (3) keveset sportolók, akik nem sportolnak heti rendszerességgel.

Tanulmányunkban három korábbi budapesti egyetemisták körében készített kutatás eredményeit is bemutatjuk. 2010-ben 619, 2006-ban 539 és 2004-ben 641 válaszadónk volt, véletlen mintavétellel. 2004-ben még online és személyes megkérdezés, később csak online megkérdezés volt a módszer. Az online kérdőíveket Excel, illetve SPSS13 program segítségével dolgoztuk fel.

\section{Eredmények}

A következőkben a 2004-es, 2006-os és 2010-es kutatások, valamint a 2014-es kutatásunk eredményeit mutatjuk be. A legnagyobb hangsúlyt a legutolsónak szánjuk, de szeretnénk a 10 évet áttekinteni, a főbb változásokra a figyelmet felhívni. A kuta- 
tások nem tekinthetők longitudinális kutatásnak, különböző módokon is gyújtöttük az adatokat, és a kérdések sem egyeztek meg 100 százalékban. Kutatásaink exploratív célúak voltak, az általánosítás további vizsgálatokat igényel, de mindenképpen tudunk egyfajta képet adni a választott célcsoportról.

\section{Mivel töltik az egyetemisták a szabad idejüket?}

A mintákban szereplő budapesti egyetemisták 2004 és 2010 között leggyakrabban passzív szabadidős tevékenységeket végeztek, zenét hallgattak, újságot olvastak, napi gyakorisággal vagy legalábbis hetente többször. A nemeket összehasonlítva - két független mintás t-próbával - a férfiak többet sportoltak, kirándultak, a nőket pedig jobban vonzotta a kultúra, többet jártak koncertre, színházba, moziba, múzeumba. Ezeken kívül a nők többet tévéztek, és a nézelődés-vásárlás is gyakoribb volt náluk, mint férfi társaiknál.

2014-ben a korábbiaknál aktívabb szabadidő-eltöltési formák jellemezték az egyetemistákat: a budapesti hallgatók leginkább a barátaikkal találkoztak, beszélgettek szabad idejükben (ahogy ez a szekunder források szerint is az egyik legnépszerúbb szabadidős tevékenység). Közkedvelt volt az internetezés, illetve a közösségi média használata. A válaszadók több mint $75 \%$-a legalább hetente követte ismerősei üzeneteit a közösségi médiában, illetve tett fel híreket saját életével kapcsolatban. A sportolás a harmadik legnépszerúbb szabadidős tevékenység volt (lásd 1. táblázat), míg 2010-ben az ötödik, korábban az első ötben nem is szerepelt. A mozgással töltött idő fordítottan volt arányos a passzív, „ülős” tevékenységek mennyiségével: minél többet mozgott valaki, annál kevesebb idốt töltött internetezéssel, televíziónézéssel és olvasással. 2014-ben is vásárlással tölteni a szabad időt inkább a lányok, míg számítógépes játékokkal foglalkozni inkább a fiúk szerettek (Kozma et al. 2015).

Örömteli, hogy a vizsgált 10 éves idôszakban a tévézés népszerűsége csökkent, a sportolás népszerủsége és a barátokkal eltöltött idő fontossága nőtt a budapesti egyetemisták körében.

1. táblázat. Leggyakoribb szabadidős tevékenységek

\begin{tabular}{|c|c|c|c|}
\hline 2004 (641 fö) & 2006 (539 fö) & 2010 (619 fö) & 2014 (3374 fö) \\
\hline Zenehallgatás & Zenehallgatás & Zenehallgatás & $\begin{array}{c}\text { Barátokkal való } \\
\text { találkozás }\end{array}$ \\
\hline Tv-nézés & Újságolvasás & Újságolvasás & Internetezés \\
\hline Újságolvasás & Tv-nézés & $\begin{array}{c}\text { Barátokkal való } \\
\text { találkozás }\end{array}$ & Sportolás \\
\hline
\end{tabular}

Forrás: saját szerkesztés Szabó 2013 és a Bíbor Béka 2014 alapján 


\section{Miért sportolnak a hallgatók?}

A mintákban szereplố rendszeresen sportoló budapesti egyetemistáknak 2004 és 2010 között fő indokuk a sportolásra az volt, hogy a sport kikapcsolódást, szórakozást jelent, fejleszti az egészséget és a fittséget, a sport élvezet, jól érzik magukat közben, valamint a szép formás test elérésének célja is elérhető. A szekunder források szerint a nők a társaság, a fittség és az egészség, valamint a testsúlykontroll miatt sportolnak (a mintáink is ezt megerősítették), a férfiak pedig a győzelem, a versengés, a siker miatt. Mintáinkban a férfiaknak a kikapcsolódás-szórakozás, az egészség és az élvezet voltak a legfontosabb motiválók, a szekunder forrásoktól kissé eltérően. A két független mintás t-próba eredményei szerint a férfiakra sokkal jellemzőbb indok volt a versengés, valamint hogy együtt legyenek a barátaikkal.

A lányok 2014-ben is ,jó alakra” vágytak, a válaszadók több mint fele megemlítette ezt a motívumot, de ami külön érdekes, hogy a fiúknak is több mint harmada. A fuúknak elsősorban azonban a fittség volt a fő motiváló erő. Megjelent ugyanakkor egy közös szempont is, az egészség, összességében ez volt a legjellemzőbb (ahogy a szekunder forrásokban is ez egy állandó, fontos motiváló). Jelentős különbség mutatkozott a sokat és a keveset sportoló hallgatók válaszaiban. A legalább hetente háromszor sportoló fiatalok közel fele örömét leli a sportolásban, míg a ritkábban sportolóknak csupán harmada. Ugyanígy nagy volt az eltérés a sikerélmény fontosságában, amely szintén a rendszeresen sportolók számára fontosabb, a többiek számára kevésbé. A barátokkal való sportolás továbbra is inkább a fiúkra igaz, a lányoknál kisebb volt a jelentősége (Kozma et al. 2015).

A 10 évet áttekintve a kikapcsolódás mint motiváló tényező 2014-re az ötödik helyre szorult, és jobban előtérbe került a jó alak elérésének vágya (lásd 2. táblázat). Az egészség, a fittség és az élvezet ,örök motiválók”.

2. táblázat. Motiváló tényezők

\begin{tabular}{|c|c|c|c|}
\hline $2004(485$ fö) & $2006(440$ fö $)$ & $2010(427$ fó) & 2014 (3374 fó) \\
\hline Kikapcsolódás & Kikapcsolódás & Kikapcsolódás & Egészség \\
\hline Egészség & Egészség & Egészség & Jó alak \\
\hline Fittség & Fittség & Fittség & Fittség/teljesítóképesség \\
\hline Élvezet & Élvezet & Élvezet & Élvezet \\
\hline Jó alak & Jó alak & Jó alak & Kikapcsolódás \\
\hline
\end{tabular}

Forrás: saját szerkesztés Szabó 2013 és a Bíbor Béka 2014 alapján

2004-ben, 2006-ban és 2010-ben csak a rendszeresen sportolók körében végeztük el az elemzéseket, ahogy a tanulmány további részében is.

A 2014-es felmérésben az egyes sportágak szerinti motivációkat is vizsgáltuk. Az egészség ápolásának motívuma minden sportnál jellemző volt, de különösen a túrázóknál (65\%) és az aerobikozóknál (60\%), ugyanakkor legkevésbé a csapatsportoknál 
(33-40\%) és a táncnál (41\%). A fizikai teljesítőképesség, fittség javítása a testépítőknél volt a legfőbb (50\%), míg szintén a csapatsportoknál és a táncolóknál a legkevésbé jelentős. Örömforrásnak a sportot a csapatsportok (59-62\%) és a tánc (59\%) követői tartották leginkább, míg a „vonzó külsőt” az aerobik és a testépítés gyakorlói (67\%, illetve 58\%) értékelték fontosabbnak. A barátokkal való időtöltésre a futballt tartották a legalkalmasabbnak (46\%) a budapesti hallgatók (Kozma et al. 2015).

Az adott sportág választásának fó okai a rendszeresen sportoló megkérdezettjeink körében 2004 és 2010 között változatlan volt: közelben van, egyedül is lehet csinálni, tehetség, adottság megléte, a barátok társasága, nem kell hozzá extra felszerelés. A két független mintás t-próba eredményei szerint valamennyi tényezőt tekintve különböztek a férfiak és a nők. A férfiaknak sokkal fontosabb motiváló volt a barátaik, évfolyamtársaik társasága, a családi hagyomány, a divat és az újdonság, mint a nőknek, valamint az, hogy mihez van tehetségük, adottságuk. A nőknek pedig az volt fontos, hogy ne kelljen extra felszerelés az űzött sportághoz, és azt is jobban megnézték, mire van pénzük, valamint számukra sokkal fontosabb volt a közelség és hogy egyedül is lehessen űzni az adott sportágat.

2014-ben a megkérdezett fiatalok 68\%-a a „kipróbáltam és bejött”, míg 42\%-a a „láttam és megtetszett” érzelmi magyarázatot adta arra a kérdésre, hogy miért azt a sportot választotta, amelyet jelenleg üz. Emellett a racionalitás és a kényelem motívumai is megjelentek a válaszokban, ahogy a korábbi években is: továbbra is fontos volt, hogy a választott sport az adottságaiknak megfeleljen, sőt fontosabb, mint a korábbi években, valamint hogy a lakóhelyük közelében legyen végezhető, bár a közelség jelentősége csökkent az elmúlt évekhez képest (lásd 3. táblázat).

3. táblázat. A sportágválasztás meghatározó elemei

\begin{tabular}{|c|c|c|c|}
\hline 2004 & 2006 & 2010 & 2014 \\
\hline Közelben van & Közelben van & Közelben van & „Kipróbáltam és bejött” \\
\hline Egyedül is lehet & Egyedül is lehet & Egyedül is lehet & Adottság, tehetség \\
\hline Adottság, tehetség & Adottság, tehetség & Adottság, tehetség & Közelben van \\
\hline Barátok & Barátok & Barátok & "Láttam és megtetszett” \\
\hline $\begin{array}{c}\text { Nem igényel extra } \\
\text { felszerelést }\end{array}$ & $\begin{array}{c}\text { Nem igényel extra } \\
\text { felszerelést }\end{array}$ & $\begin{array}{c}\text { Nem igényel extra } \\
\text { felszerelést }\end{array}$ & Barátok/szülők \\
\hline
\end{tabular}

Forrás: saját szerkesztés Szabó 2013 és a Bíbor Béka 2014 alapján

A 2014-es kutatásban sportáganként is vizsgálódtunk. A túrázás/gyaloglás sportág „könnyen elérhető sport”, a többi sportághoz képest könnyű elkezdeni, mind hely-, mind költség- és technikai igények vonatkozásában. A táncosok távolabbi helyszínre is elmennek és kevésbé költségérzékenyek. A táncosok űzik saját bevallásuk szerint leginkább az adottságaiknak megfelelő sportot. Négy nagy számban űzött egyéni sport (futás, kerékpározás, kondizás, úszás) esetében jellemzően minden szempontból „átlagos” válaszokat kaptunk, nem voltak szignifikáns eltérések. A csapatsportok kiválasz- 
tásánál hangsúlyos volt a hallgató sporttal kapcsolatos előélete, valamint a médiában látható példaképeknek nagyobb vonzereje volt, amikor ezen sportágak elkezdéséről döntöttek a hallgatók (Kozma et al. 2015).

\section{Melyek a legnépszerúbb sportágak?}

2004 és 2010 közötti vizsgálatainkban az anyagi helyzet nem befolyásolta a sportolás mennyiségét, de befolyásolta a sportágválasztást. A 4. táblázatban látható, hogy a szekunder forrásokkal megegyezően az aerobik és a kondizás töretlen népszerūségnek örvend a teljes 2004 és 2014 közötti időszakot vizsgálva. 2004-ben azt állapíthattuk meg, hogy a foci kivételével eltüntek a csapatsportok, és az egyéni sportok uralták a legkedveltebb sportágak listáinak első helyeit. 2006-ban megjelent a kosárlabda, ami 2010-ben is a leggyakrabban űzött sportágak között volt az egyetemisták körében, valamint a teniszhez és a tánchoz is kell partner. Lehet, hogy mégsem individualizálódott teljesen a szabadidősport.

2014-ben a válaszadók összességét tekintve a futás/kocogás volt a legkedveltebb szabadidősport, a válaszadók 29\%-a ezt választotta legalább hetente egyszer. A fiúk körében a legfelkapottabb rendszeresen üzött sport a testépítés/kondizás volt (a válaszadók 39\%-a végezte ezt legalább hetente egyszer), ezt követte a futás/kocogás (27\%), majd a labdarúgás (17\%), a gyaloglás/túrázás (10\%), az úszás és végül a küzdősportok (8-8\%). A lányok körében a futás/kocogás volt az első helyen (a válaszadók 30\%-a végezte ezt legalább hetente egyszer), ezt követte az aerobik (27\%), majd a testépítés/kondizás (17\%), a gyaloglás/túrázás (13\%), a tánc (10\%), végül az úszás és a kerékpározás (7-7\%) (Kozma et al. 2015).

2014-re reneszánszát élte a futás/kocogás, miközben az aerobik és a testépítés is folyamatosan a legnagyobb számú említést kapták az elmúlt 10 évben. 
4. táblázat. A leggyakrabban űzött sportágak

\begin{tabular}{|c|c|c|c|}
\hline 2004 & 2006 & 2010 & 2014 \\
\hline $\begin{array}{l}\text { Aerobik } \\
(13,5 \%)\end{array}$ & $\begin{array}{c}\text { Aerobik } \\
(13,4 \%)\end{array}$ & $\begin{array}{c}\text { Testépítés, kondizás } \\
(17 \%)\end{array}$ & $\begin{array}{l}\text { Futás } \\
(29 \%)\end{array}$ \\
\hline $\begin{array}{l}\text { Foci } \\
(13,5 \%)\end{array}$ & $\begin{array}{l}\text { Futás, kocogás } \\
\qquad(13,4 \%)\end{array}$ & $\begin{array}{l}\text { Aerobik } \\
(12,8 \%)\end{array}$ & $\begin{array}{c}\text { Testépítés, kondizás } \\
(28 \%)\end{array}$ \\
\hline $\begin{array}{c}\text { Testépítés, kondizás } \\
(11 \%)\end{array}$ & $\begin{array}{l}\text { Foci } \\
(9,8 \%)\end{array}$ & $\begin{array}{c}\text { Foci } \\
(10,6 \%)\end{array}$ & $\begin{array}{c}\text { Aerobik } \\
(13 \%)\end{array}$ \\
\hline $\begin{array}{l}\text { Úszás } \\
(10,1 \%)\end{array}$ & $\begin{array}{c}\text { Testépítés, kondizás } \\
(9,3 \%)\end{array}$ & $\begin{array}{l}\text { Futás, kocogás } \\
\qquad(10,2 \%)\end{array}$ & $\begin{array}{c}\text { Túrázás } \\
(11 \%)\end{array}$ \\
\hline $\begin{array}{c}\text { Futás, kocogás } \\
(8,5 \%)\end{array}$ & $\begin{array}{l}\text { Úszás } \\
(7,3 \%)\end{array}$ & $\begin{array}{l}\text { Úszás } \\
(6,4 \%)\end{array}$ & $\begin{array}{l}\text { Foci } \\
(9 \%)\end{array}$ \\
\hline $\begin{array}{l}\text { Kerékpározás } \\
(7,2 \%)\end{array}$ & $\begin{array}{c}\text { Kerékpározás } \\
(6,6 \%)\end{array}$ & $\begin{array}{l}\text { Tenisz } \\
(5,7 \%)\end{array}$ & $\begin{array}{c}\text { Kerékpározás } \\
(9 \%)\end{array}$ \\
\hline $\begin{array}{c}\text { Torna, gimnasztika } \\
(5,8 \%)\end{array}$ & $\begin{array}{c}\text { Küzdősportok } \\
(5,5 \%)\end{array}$ & $\begin{array}{l}\text { Kosárlabda } \\
\quad(5,1 \%)\end{array}$ & $\begin{array}{l}\text { Úszás } \\
(8 \%)\end{array}$ \\
\hline $\begin{array}{c}\text { Küzdősportok } \\
(5,6 \%)\end{array}$ & $\begin{array}{c}\text { Kosárlabda } \\
(5,2 \%)\end{array}$ & $\begin{array}{c}\text { Tánc } \\
(5,1 \%)\end{array}$ & $\begin{array}{l}\text { Tánc } \\
(6 \%)\end{array}$ \\
\hline
\end{tabular}

Forrás: saját szerkesztés Szabó 2013 és a Bíbor Béka 2014 alapján

A 2014-es felmérésben részt vevő lányok aránya (62\%) jóval magasabb volt, mint amekkora részesedést a lányok képviselnek a nyolc budapesti egyetem alkotta sokaságban (49\%). Ezt figyelembe véve a 2014-es összesített sportág-népszerüségi lista a lányokra és fiúkra jellemző népszerűségi sorrendből a nemek sokasági részarányának megfelelő súlyozással készült. A 2004-2010-es véleményfelmérésekben a nemek aránya megközelítőleg ugyanaz volt, mint a teljes egyetemi sokaságban.

A 2014-es kutatás szerint, akik kipróbálnának egy új sportágat, azok leginkább a kondizásban, testépítésben gondolkodtak, főleg ha nem sportoltak még rendszeresen (18-23\%). A kevésbé gyakran mozgó fiatalok körében viszonylag magas volt a futást és az úszást mint kipróbálandó sportágat választók száma (10-13\%). A lányok jellemzően nyitottak voltak az aerobik és a tánc valamely fajtájára, a fiúk a küzdősportok felé nyitnának leginkább (15-18\%) (Kozma et al. 2015).

\section{A szabadidősportra való költés}

A 2004-es kutatásban a rendszeresen sportolók 30\%-a nem költött a szabadidősportra, 2006-ban ez 28,6\%, 2010-ben pedig 16\% volt, ebből következően otthon vagy a szabadban mozgott. A megkérdezettek 48\%-a hatezer forint alatt, 22\%-a hat és tízezer forint között, 13\%-a tízezer forint feletti összeget költött havonta 2010-ben. Átlagosan növekedett a szabadidősportra való költés. Nem volt különbség a varianciaanalízis eredményei szerint sem a nemek, sem a lakóhely, sem anyagi helyzet szerint az egyes csoportok költését tekintve. 
2014-ben, akik legalább hetente háromszor sportoltak, jellemzően többet is költöttek sportolásra. 33\%-uk havi tízezer forintnál is többet költött (2010-ben ez 13\% volt csak). Az intenzíven sportolók harmada havi ötezer forintnál is kevesebbet költött. Az egyes sportágak eltérő anyagi terhet jelentenek híveik számára. A legkevesebb pénzből a túrázók és a röplabdázók jöttek ki (több mint felük ötezer forint alatt költött havonta), a legtöbbet pedig a testépítők, az úszók és a táncosok költötték kedvenc sportjukra (29\%, illetve 27-27\% havi tízezer forintnál többet).

\section{Szolgáltatók igénybevétele, szolgáltatásminőség}

2010-ben a sportoló megkérdezettek 66\%-a, 2006-ban 57,7\%-a igénybe vett üzleti alapon működő szabadidősport-szolgáltatót. Közterületen sportolt 38\%, otthon $30 \%$, iskolai sportpályákon 31\% és egyesületi pályákon 23\%. A nemeket és a lakhelyet tekintve nem volt különbség, viszont a lakással rendelkezők nagyobb arányban vettek igénybe üzleti alapon müködő szolgáltatókat. Legjelentősebb a szabadidősport-szolgáltatók értékelésénél az elérhető ár volt, aztán a könnyű megközelíthetőség és dobogós volt még a nyitvatartási idő megfelelősége. Az elérhetőség után a szolgáltatásminőség elemei közül a legfontosabbak: a hely belső állapota, színvonala, színvonalas sportolási lehetőség adott sportág esetén, megfelelő személyzet, vendégkör összetétele. A nemeket összehasonlítva a nőknek az átlagnál fontosabb volt az ár, a könnyű megközelíthetőség, a hely belső állapota, a megfelelő személyzet, valamint a kiegészítő szolgáltatások és a több sportág megléte egy helyen.

2014-es kutatásunkban arra a kérdésre, hogy a jelenleg használt sportlétesítményekben mivel elégedetlenek leginkább, a hallgatók a létesítmények felszereltségét és árszínvonalát emelték ki. Szintén sok válasz érkezett a „megközelíthetőség” és a hozzáférés, „nem elegendő szabad kapacitás este 6 és 9 óra között” tárgyában, azaz az elmúlt időszakban a legfontosabb tényezők nem változtak (ár, megközelíthetőség, hozzáférés). A létesítmény tisztasága csak a negyedik legnagyobb elégedetlenségforrás volt. A felszereltséggel kapcsolatban a testépítók voltak a legkritikusabbak, árszínvonal témában a táncot és az úszást űzők, a szabad kapacitások este 6 és 9 között a testépítőknek, focizóknak okozott a legnagyobb problémát. A megközelíthetőség és tisztaság az úszást űzők között volt gond.

\section{Miken kellene változtatni a több sportolás érdekében?}

2014-ben kíváncsiak voltunk arra is, miken is változtatnának a hallgatók szívesen, ha lehetőség adódna rá. Új sporthelyszínt választanának a legtöbben. Megkérdeztük azt is, minek kellene változnia ahhoz, hogy a mozgás nagyobb szerepet kapjon a megkérdezettek életében. A legjellemzőbb válasz a saját elhatározás volt, fooleg a kevésbé rendszeresen sportolók körében (70\%). Szükségük lenne továbbá közelebbi és olcsóbb 
helyszínekre (40\%), a barátok invitálására (40\%), a személyiségüknek, adottságaiknak jobban megfelelő sport megismerésére (17\%). Megkérdeztük, saját magukon túl mit gondolnak az egyetemisták arról, hogy a többi hallgató sportolási szokásait miként lehetne felpezsdíteni, mi kellene ahhoz, hogy többet mozogjanak a társaik. A legtöbben nekik szóló sportrendezvényekből akartak többet, illetve információt arról, hogy mit és hol, hogyan lehet sportolni. További ötletek voltak: a mozgást összekapcsolni valamilyen különleges tartalommal, mint például híres sportolókkal együtt mozogni vagy egy nagyszabású tömegrendezvény keretében tölteni a szabad időt, olcsóbb megoldások, több információ a mozgás élettani és lélektani hatásairól. Ha több sportpálya közül lehetne választani, ezek jobban felszereltek lennének vagy egyszerúen több sportra lennének alkalmasak, akkor többen sportolnának. Végül sokan kapcsolták a sportolást a közösségépítéshez. Szerintük a fiataloknak a fó igénye az, hogy jó társaságuk legyen, és együtt tölthessék a szabad időt, ismét visszaköszönt a barátok fontossága.

\section{Következtetések}

Az egyetemisták életében a barátok és az internet szerepe kiemelkedő napjainkban. A barátok szerepe korábbi vizsgálatok szerint is meghatározó volt, bár nem ilyen mértékben, és korábban a televíziónézés volt az egyik legfontosabb szabadidős tevékenység. Örömteli, hogy a vizsgált 10 éves időszakban a tévézés népszerüsége csökkent, a sportolás népszerűsége és a barátokkal eltöltött idő fontossága nőtt a budapesti egyetemisták körében. Barátokkal együtt is úzhetók a sportok, ez még inkább növelheti a sportolás mennyiségét. A sportolás minőségi együtt töltött idő a barátokkal. Ez főlleg az egyetemista fiúknak fontos, inkább rájuk jellemző a csapatsportok választása. A futball az ő első számú választásuk, de kondizni is szívesen járnak barátokkal. Nem vált valósággá az ezredforduló elótti Laki és Nyerges ,jóslat”, mely szerint a sport teljesen individualizálódik, bár a tendencia kétségkívül megvan, az egyéni sportok térnyerése vitathatatlan. 2014-re a futás/kocogás vált a legnépszerübb sportággá. Az aerobik és a testépítés is folyamatosan a legkedveltebb sportágak között vannak az elmúlt 10 évet tekintve. A fiúk azért sportolnak, hogy fittek, erősek legyenek, míg a lányok az alakjukat szeretnék formálni. Az egészség megőrzése, a klasszikus motiváló erő mindkét nemnél megjelent. A szakirodalomban fellelhetô további motivációs tényezők közül az öröm és a siker azoknak fontosabb, akik rendszeresen sportolnak. Ez egy „circus vitiosus”, a sok sport sikeressé, boldogabbá tesz, az öröm és a siker további sportolásra ösztönöz. Azok számára, akik jelenleg nem vagy csak rendszertelenül sportolnak, saját bevallásuk szerint nem külső, hanem belső „változtatások” szükségesek, leginkább el kellene határozni magukat. A belső motiváció, az elhatározás jóval meghatározóbb ok, mint a mozgás költségessége (miközben az átlagos szabadidősportra való költés növekedett), a kapcsolódó ismeretek hiánya vagy bármely egyéb tényező (például a szolgáltatás minősége). A kapott eredmények alapján azt gondoljuk, a szokásos szeg- 
mentálási szempontok mellett minden kínálati oldali szereplőnek érdemes lenne a célokat, motivációkat is felhasználni, amikor az egyetemistákat szeretnék elérni, nagyobb sportfogyasztásra ösztönözni.

\section{Hivatkozott irodalom}

- Bauer B. \& Szabó A. (2005). Ifúság 2004. Gyorsjelentés. Budapest, Mobilitás Ifjúságkutató Iroda.

- Bíbor Béka (2014). Öröm vagy küzdelem. (Ön)kritikus egyetemisták szabadidốs sportolása Budapesten. Forrás: www.biborbeka.hu/orom-vagy-kuzdelem. Utolsó letöltés: 2016.08.10.

- Budai E. (1999). Sport(t)örvényben fuldokolva. Új Folyam, 8 (3-4), 20-33.

- Eurobarometer (2010). Sport and physical activity. Forrás: http://ec.europa.eu/ public_opinion/archives/ebs/ebs. Utolsó letöltés: 2016.08.10.

- Eurobarometer (2014). Sport and physical activity. Forrás: http://ec.europa.eu/ public_opinion/archives/ebs/ebs. Utolsó letöltés: 2016.08.10.

- Gál A. (2008). A magyar lakosság egészségtudatossága és szabadidô-sportolási szokásai. In Földesiné Sz. Gy., Gál A. \& Dóczi T. (szerk.): Társadalmi riport a sportról 2008 (pp. 41-89). Budapest, ÖTM-MSTT.

- Gál A. (2014). „Innovatív és kreativ kommunikációs, média- és marketing tartalmak az egészségfejlesztést szolgáló fizikai aktivitás fokozásának szolgálatában". TÁMOP tanulmány. Forrás: http://sportmenedzsment.hu/wp-content/uploads/2014/06/ C\%C3\%A91csoport-anal\%C3\%ADzis.pdf. Utolsó letöltés: 2016. 08. 10.

- Gáldi G. (2004). Szabadidô-struktúra és fizikai rekreáció Magyarországon 1963-2000 között, életmód-idómérleg vizsgálatok tükrében. PhD-értekezés, Budapest: Semmelweis Egyetem.

- Goudas, M., Biddle, S. \& Fox, K. (1994). Achievement goal orientations and intrinsic motivation in physical fitness testing with children. Pediatric Exercise Science, 6, 159-167.

- Kovács K. (2011). Szabadidő és sport a Debreceni Egyetemen. Iskolakultúra, (1011), 147-162.

- Kovács K. (2013). Bourdieu, Hradil és Bandura elméleteinek vizsgálata a sportra vonatkozóan: a társadalmi, környezeti és egyéni tényezôk hatása a partiumi régió hallgatóinak sportolására. Társadalomkutatás, (2), 175-193.

- Kovács K. (2015a). Magyarországi és romániai hallgatók sportolási szokásait meghatározó szociokulturális tényezők. In Kozma T., Kiss V. Â., Jancsák Cs. \& Kéri K. (szerk.): Tanárképzés és oktatáskutatás (pp. 673-685). Debrecen, Magyar Nevelés- és Oktatáskutatók Egyesülete.

- Kovács K. (2015b). A sportolás mint támogató faktor a felsóoktatásban. Oktatáskutatók könyvtára 2. Debrecen, CHERD (ISBN 978-963-473-810-7). 
- Kozma M., Szabó Á., Huncsik P. (2015). Miért sportolnak a hallgatók? Tendenciák és „forró pontok” a budapesti egyetemisták szabadidős sportválasztásában. Magyar Sporttudományi Szemle, (3), 9-18.

- Laki L., Szabó A. \& Bauer B. (2001). Iffúság 2000. Gyorsjelentés. Budapest, Nemzeti Ifjúságkutató Intézet.

- Laki L. \& Nyerges M. (2004). A fiatalok sportolási szokásainak néhány társadalmi összefüggése. Magyar Sporttudományi Szemle, (2-3), 5-15.

- Neulinger Á. (2007). Folyamatos megerösitést igénylö tanult fogyasztás - A társas környezet és a sportfogyasztás viszonya. $\mathrm{PhD}$-értekezés. Budapest, Budapesti Közgazdasági és Államigazgatási Egyetem.

- Paár D. (2013). A magyar háztartások sportfogyasztásának gazdasági szempontú vizsgálata. $\mathrm{PhD}$-értekezés. Sopron, Nyugat-magyarországi Egyetem.

- Pataki Gy. (2007). A sport helye és jelentösége a magyar fatalok életmódjában a 21. század küszöbén. Szakdolgozat. Budapest, BCE.

- Perényi Sz. (2010). Sportoló és nem sportoló fatalok életvitelhez kapcsolódó értékei. Ph.D. értekezés. Budapest, SOTE-TF.

- Perényi Sz. (2013). Alacsonyan stagnáló mozgástrend: a fizikai inaktivitás újratermelődése. In Székely L. (szerk.): Magyar Iffúság 2012 (pp. 229-249). Budapest, Kutatópont.

- Pluhár Zs., Keresztes N. \& Pikó B. (2003). Ép testben ép lélek. Középiskolások értékrendje fizikai aktivitásuk tükrében. Magyar Sporttudományi Szemle, (2), 29-33.

- Polányi G. (1998). A sportolás és a testmozgás társadalmi összefüggései. In Szívós P. \& Tóth I. Gy. (szerk.): Társadalmi tény-kép (pp. 45-52). Budapest, TÁRKI.

- Szabó, A. \& Bauer, B. (2009). Ifúság 2008. Gyorsjelentés. Budapest, Szociálpolitikai és Munkaügyi Intézet.

- Szabó Á. (2013). Mi történt 2004 és 2010 között a budapesti egyetemisták szabadidósport-fogyasztásában? Budapest: BCE Múhelytanulmány, Vállalatgazdaságtan Intézet. Forrás: http://edok.lib.uni-corvinus.hu/478/1/Szabo_154.pdf. Utolsó letöltés: 2015.08. 10.

- Székely M. (2014). Az egyetemi sport fejlesztési terve - Szabadidósport az egyetemen. Előadás 2014. október 2. Debrecen.

- Szmodis M., Bosnyák E., Bede R., Farkas A., Protzner A., Trájer E., Udvardy A., Tóth M. \& Szőts G. (2013). Az MSTT Mozgás = Egészség Programjának magyarországi tapasztalatai - A fiatal generációk fizikai teljesítményének háttérvizsgálata. Népegészségügy, 91 (2), 141-149. 


\title{
Lepeš Josip, Halasi Szabolcs, Stajer Anita
}

\section{A testnevelés és a sport egészségmegőrző hatása a vajdasági fiatalok értékrendszerében}

\begin{abstract}
Absztrakt
A hipokinézia mint általános társadalmi jelenség, már egész fiatal korban jelentkezik. A mozgáshiánynak komoly egészségügyi következményei vannak az emberi szervezetre nézve: elhízás, érrendszeri megbetegedések, helytelen testtartás, cukorbetegség stb. Rendszeres testmozgással nemcsak elkerülhetők ezek a betegségek, hanem javítható az állóképesség, közérzet, az életminőség stb. A kutatás célja az egyetemisták fizikai aktivitásának és attitűdjeinek vizsgálata. A szabadkai Magyar Tannyelvű Tanítóképző Karról 116 hallgató (nő: 93; férfi: 23) töltötte ki az egészségügyi, étkezési, egészségtelen szokásokkal és ülő életmóddal kapcsolatos kérdőívet, és közülük 10-en viselték a Polar órákat, amellyel a napi fizikai aktivitásukat vizsgáltuk. A hallgatók pozitívan értékelték a testnevelést és a fizikai aktivitás hatását az egészségre, ennek ellenére a 35\%-uk nem foglalkozik semmilyen jellegű testmozgással, és napi szinten átlagosan 8 óra 44 percet töltenek ülő helyzetben.
\end{abstract}

\section{Bevezetés}

Szoros összefüggés figyelhető meg az egészség, egészséges életmód és testmozgás között. Utóbbi beépítése mindennapi rutinunkba elengedhetetlennek bizonyul. Napjainkban nagyobb hangsúlyt helyeznek a testmozgásra, mint korábban, különösen a súlyos elhízás és az azt követő betegségek elterjedéséből eredően (Kohl 2001; WHO 2002; Blair et al. 2004; Hernelahti et al. 2004). A fizikai aktivitás hiányát az öt leggyakoribb halálos kockázati tényezői közé sorolják a világon, valamint a magas vérnyomást, túlsúlyt és az elhízást. Mind a három betegség kialakulásához igen nagy mértékben hozzájárul a testmozgás hiánya (WHO 2009). Emellett a testmozgás hatással van a mentális egészségünkre és az életminőségünkre is (Sjogren et al. 2006). A fizikai és mentális dimenziók szoros kapcsolatban vannak egymással és kölcsönösen hatnak egymásra (Kovács \& Perényi 2014). Közismert, hogy a testmozgás típusa és mértéke jelentős szerepet tölt be az egyén egészségének és optimális testsúlyának megőrzésében, továbbá csökkenti bizonyos krónikus betegségek kialakulásának veszélyét. Egyértelmű kapcsolat figyelhető meg az intenzív testmozgás és az optimális súly- 
fenntartás között (Blair \& Hardman 1995). A fizikai aktivitás pozitív hatást gyakorol a test minden szintú fiziológiai rendszerére, legfóképpen a csont- és izomrendszerre, szív- és érrendszerre, légzőszervrendszerre, endokrin és immunrendszerre (Mikalački, 2005; Mišigoj-Duraković 2006). A modern társadalomban, az egyre magasabb fokú automatizáció és gépesítés következtében a kor emberének nincs szüksége különösebb mozgásra mindennapi élete és munkája során. A mozgáshiány tükrözi a mai ember életét és munkáját, miközben köztudott, hogy a mozgás az egészség egyik legfontosabb tényezője (Pantelić et al. 2008).

Sajnos manapság a gyerekek egyre kevesebbet mozognak, játszanak mozgásos játékokat, míg az ülő életmódban töltött idő egyre csak növekszik (Marshall et al. 2002). A gyerekek már a napi ajánlott 60 perc intenzív testmozgást sem tudják teljesíteni (Mackintosh et al. 2011). A gyerekeknél a kulcsszó a prevenció/megelózés kellene hogy legyen, hogy a testmozgás alapjait, a testmozgás iránti szeretetet már gyermekkorban elsajátítsák. Így kiegyensúlyozottabb lehet a gyermek pszichofizikai fejlődése, valamint a társadalmi alkalmazkodása is (Đorđić \& Bala 2006). A gyermekkorban elsajátított fizikai aktivitással és táplálkozással kapcsolatos minták/szokások meghatározzák a felnőttkori viselkedést is. A túlsúlyos gyerekek 70\%-a túlsúlyos felnőtté válik, illetve a túlsúlyos szülők gyermekei is túlsúlyossá válnak (Dunton 2005; Horvat et al. 2009). Súlyos következményei lehetnek az egészséget, a fizikai aktivitást és a munkahelyi helytállást illetően. A megengedettnél több testzsír rendkívül negatív hatást gyakorol a testre, megléte súlytöbbletet jelent az ízületekre és az azok körüli szövetekre, ami számos betegség kialakulásának veszélyét növeli, vastagbélrák, cukorbetegség, továbbá vesét és szívet érintő megbetegedések (Sinha et al. 2002). A legfőbb probléma, hogy a gyermekek és fiatalok szabad idejében a szervezett fizikai aktivitás nem igazán jelenik meg, ez betudható a szülók szerény anyagi helyzetének is, mivel ezek az aktivitások általában nem ingyenesek. Azért van óriási szerepük azon intézményeknek (óvodáknak, iskoláknak), amelyek gyerekekkel/fiatalokkal foglalkoznak, hogy lehetővé tegyék megfeleló impulzusok megszerzését a fizikai és motoros fejlődés érdekében. Ez csakis a testnevelésórákon valósítható meg, ezért fontos, hogy az óra felépítése és tartalma érdekes, ösztönző, dinamikus legyen és minden gyermek örömét lelje benne. Így elérhetô a megfelelő kapcsolat a testneveléssel, fizikai aktivitással, és kialakulnak az egészséges szokások, amelyeket követnek gyermek-, fiatal- és felnőttkorukban, egészen életük végéig. A fiatalkorban kialakult negatív attitúdök negatívan befolyásolják a fizikai aktivitásra való hajlandóságot felnőttkorban is (Bailey 2006; Barnett et al.2009; Cliff et al. 2009; Haugen et al. 2011).

Jelen tanulmány célja a szabadkai Magyar Tannyelvú Tanítóképző Kar hallgatói körében folytatott adatgyújtés ismertetése, mely az alanyok szabad idejének, testmozgásának és ülő életmódjának feltérképezésére irányult. A jövő pedagógusainak életmódját és életminőségét fontos nyomon követni és lehetőség szerint annak növelésére és javítására törekedni. Hiszen ők nemcsak a saját maguk egészségéért felelnek, hanem leendő tanítványaik számára is fontos mintát jelentenek. A kutatás eredményeit figyelembe véve és ismertetve a hallgatókkal talán rendszeresebben sportolná- 
nak. Korábbi kutatások bizonyítják, hogy a sportolás rendszeres formája hozzájárul a hallgatók tanulmányi eredményességéhez, illetve ahhoz, hogy ellenállóbbak legyenek a mindennapi stresszel, negatívumokkal szemben, egészségesebbnek, boldogabbnak érezzék magukat és elégedettebbek legyenek életükkel. Ugyanakkor a térség hallgatóit vizsgálva azt is láthatjuk, hogy a rendszeresen sportolók aránya drasztikusan csökken a felsőoktatásba lépve a fiatalok körében a középiskolás korosztályhoz képest (Kovács 2014; Kovács 2015).

\section{Módszerek}

A 2015/2016-os tanév során végzett felmérés célja a szabadkai Magyar Tannyelvű Tanítóképző Kar hallgatói szabadidő-eltöltési szokásainak feltérképezése, ami öszszesen 116, a kutatásban önkéntesen részt vevő alapképzésben részesülő hallgatóra irányult (23 férfi és 93 nő). Az átlagéletkor 22,45 volt. A kérdőív 31 kérdésből állt, melyek 5 csoportba sorolhatóak: leíró adatok (3 kérdés), egészségügyi szokások (5 kérdés), étkezési szokások (5 kérdés), ülő életmód (14 kérdés) és egészségtelen szokások (4 kérdés). Illetve a kutatásban részt vevő hallgatók egy része (10 nő) Polar A300 típusú órát ${ }^{1}$ viselt 60 napon keresztül, amellyel a hallgatók napi aktivitását figyeltük meg, azaz mennyi időt töltött a hallgató alvással, fekvéssel, állással, járással, fizikailag megterhelő mozgással. Minden egyes hallgató esetében az órákat az alap antropometriai adatokkal állítottuk be, és két hónapos viselés és folyamatos számítógéppel való szinkronizálás ${ }^{2}$ után megkaptuk a hallgatók napi aktivitására vonatkozó adatokat. A testméretekre vonatkozó adatgyújtés, mint a testtömeg és testmagasság, a szabványok szerinti eljárásokkal és eszközökkel történt, majd ennek megfelelően a testtömegindex (magasság/ súly²) kiszámítására is sor került. Az adatok feldolgozása az SPSS 20 statisztikai program segítségével történt. A leíró statisztikai adatok és a gyakorisági eloszlás összevetése nemekre való tekintettel valósult meg. A parametrikus adatok feldolgozása kétmintás t-teszttel történt, míg a nem parametrikus adatoké Mann-Whitney U teszttel.

\section{Eredmények}

A kutatásban az adatok közül először a kérdőívre beérkezett válaszokat elemeztük, majd a Polar A300 készülék adatait dolgoztuk fel.

A kutatásban részt vevő hallgatók elmondása szerint egy átlagos hét alatt közel egy teljes napot töltenek üléssel, viszont kevesebb mint heti két órát töltenek valamilyen testmozgással.

1 http://support.polar.com/en/support/a300

2 Polar Flow Sync szoftver; https://flow.polar.com/ 
1. táblázat. Nemek közötti különbségek $(\mathrm{N}=116)$

\begin{tabular}{|l|c|r|r|c|}
\hline & Nem & Átlag & Szórás & \multirow{2}{*}{ t } \\
\hline \multirow{2}{*}{ BMI $\left(\mathrm{kg} / \mathrm{m}^{2}\right)$} & $\mathrm{F}$ & 26.54 & 7.14 & \multirow{2}{*}{$4.97^{*}$} \\
\cline { 2 - 4 } & $\mathrm{N}$ & 21.81 & 2.90 & \\
\hline \multirow{2}{*}{ Tv/DVD (óra/hét) } & $\mathrm{F}$ & 8.83 & 6.00 & \multirow{2}{*}{-1.28} \\
\cline { 2 - 4 } & $\mathrm{N}$ & 9.69 & 6.28 & \\
\hline \multirow{2}{*}{ PC (óra/hét) } & $\mathrm{F}$ & 14.83 & 10.84 & \multirow{2}{*}{0.43} \\
\cline { 2 - 4 } & $\mathrm{N}$ & 13.81 & 10.00 & \\
\hline \multirow{2}{*}{ Tv/DVD+PC } & $\mathrm{F}$ & 23.65 & 12.88 & \multirow{2}{*}{-0.29} \\
\cline { 2 - 4 } & $\mathrm{N}$ & 23.50 & 12.45 & \multirow{2}{*}{0.89} \\
\hline \multirow{2}{*}{ Fizikai aktivitás (perc/hét) } & $\mathrm{F}$ & 120.00 & 80.91 & \\
\cline { 2 - 4 } & $\mathrm{N}$ & 99.57 & 101.31 & \\
\hline
\end{tabular}

Forrás: saját kutatás

BMI-testtömegindex; Tv/DVD-televízió, filmek; PC-számítógép; F-férfi; N-nő; t-független kétmintás t-próba; ${ }^{*} \mathrm{p} \leq 0,05$

A kutatás férfi alanyai fizikailag aktívabbak, kevesebb időt töltenek a televíziózással, viszont többet a számítógép előtt a női alanyokhoz képest, ez a különbség egyik változónál sem mutatkozott szignifikánsnak. Csupán a testtömegindex-változók mutattak szignifikáns különbséget a kutatásban részt vevő nők és férfiak között $(t=4.97$; $\mathrm{p} \leq 0,05)$. Az adatok pedig arra mutattak rá, hogy a karon tanuló férfiak nagyobb hajlamosságot mutatnak az elhízásra az Egészségügyi Világszervezet referenciaadatai szerint (WHO 2002).

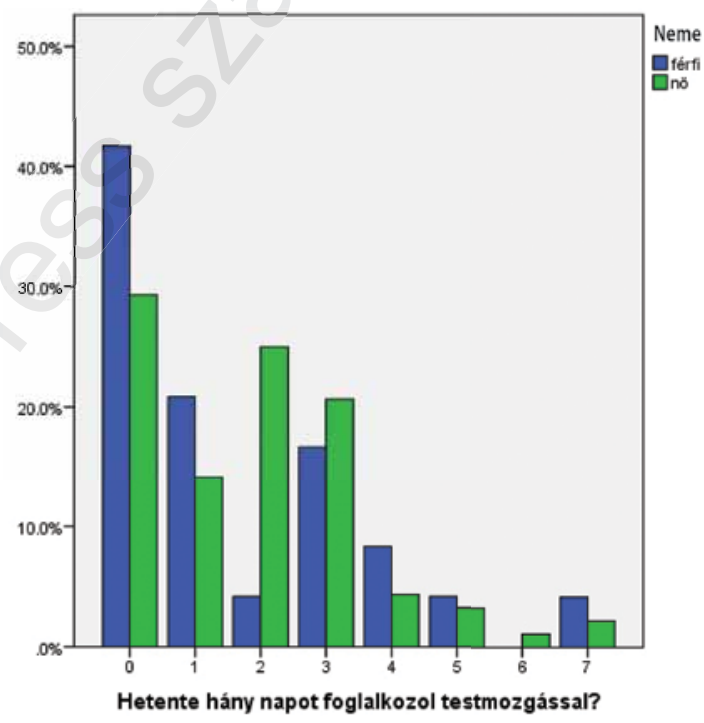

1. ábra. A testedzéssel töltött napok száma hetente nemenként $(\mathrm{N}=116)$ Forrás: saját kutatás 
A kutatás rámutatott arra, hogy a karon tanuló nők 29,3\%-a, míg a férfiak 41,7\%-a nem folytat semmilyen testmozgást szabad idejében, míg a kutatásban részt vevő férfiak 20,9\%-a, a nők 45,7\%-a legalább kétszer-háromszor hetente végez valamilyen testmozgást.

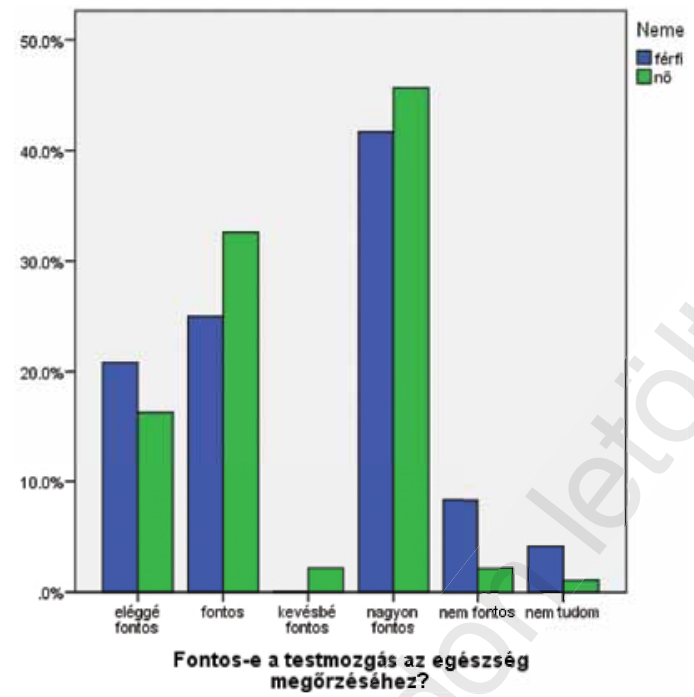

2. ábra. A testmozgás iránti attitúdök nemenként $(\mathrm{N}=116)$ Forrás: saját kutatás

A hallgatók 75,8\%-a véli úgy, hogy a testmozgás fontos vagy nagyon fontos szerepet játszik az egészség megőrzésében.

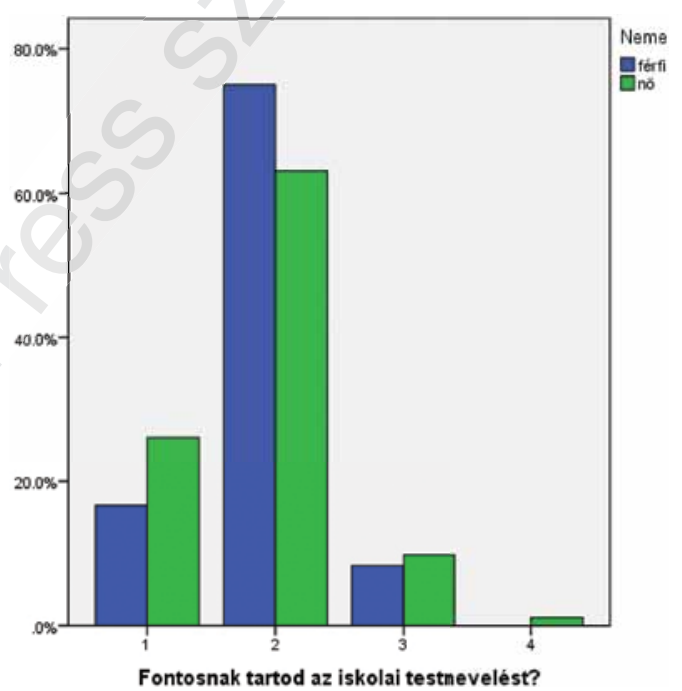

3. ábra. A testnevelés fontossága nemenként $(\mathrm{N}=116)$

Forrás: saját kutatás 
A megkérdezett hallgatók 23,7\%-a fontosabbnak tartja a testnevelést más tantárgyaknál, 64,4\%-a úgy véli, hogy egyenértékű az iskolai képzés más területeivel, míg 9,3\%-uk szerint a különböző területeket nem lehet összehasonlítani, egy hallgató válaszolta, hogy kevésbé fontos a testnevelés, mint az egyéb területek.

A hallgatók napi aktivitását a Polar A300 készülékekkel is mértük. A kapott eredmények a 2. táblázatban láthatók.

2. táblázat. A hallgatók napi aktivitása $(\mathrm{N}=116)$

\begin{tabular}{|l|c|c|c|c|}
\hline & Átlag & Szórás & Min. & Max. \\
\hline Fekvés (óra: perc) & $8: 57$ & $2: 14$ & $2: 05$ & $18: 04$ \\
\hline Alvás (óra: perc) & $7: 33$ & $2: 10$ & $1: 49$ & $12: 27$ \\
\hline Ülés (óra: perc) & $8: 44$ & $2: 32$ & $0: 50$ & $16: 08$ \\
\hline Állás (óra: perc) & $4: 36$ & $1: 47$ & $0: 07$ & $13: 44$ \\
\hline Járás (óra: perc) & $0: 41$ & $0: 32$ & $0: 00$ & $2: 56$ \\
\hline Futás (óra: perc) & $0: 04$ & $0: 08$ & $0: 00$ & $1: 10$ \\
\hline
\end{tabular}

Forrás: saját kutatás

A Polar órát használó hallgatók naponta átlagban 8 óra 57 percet töltöttek fekvő helyzetben, aminek nyilván nagy része az alvás (7 óra 33 perc), viszont előfordulhatott, hogy a hallgatók úgy tanultak, olvastak vagy esetleg filmet néztek, majdnem ugyanennyit töltöttek ülő helyzetben is (8 óra 44 perc), míg aktív életmódban viszont összesen 5 órát és 21 percet töltöttek.

\section{Összegzés és következtetések}

A túlsúly és az alacsony fizikai állóképesség számos anyagcserével összefüggésbe hozható rizikófaktort jellemez, mely növeli a hallgatók esetleges krónikus megbetegedéseinek veszélyét (Sasceck et al. 2010). Számos kutatás bizonyítja, hogy a fiatal felnőtt lakosság életvitele fokozza a krónikus betegségek későbbi kialakulásának esélyét (Sparling 2003). Az elhízás és magas testsúly nagymértékben korrelál a testmozgás hiányával az európai felnőtt lakosság körében (Martinez-Gonzáles et al.1999). A hallgatók körében megnövekszik az üléssel eltöltött idő és csökken a testmozgás szintje az egyetemi éveik alatt. A televíziónézés, számítógép-használat, videojáték és egyetemi feladatvégzés, mind üléshez kötött tevékenységek, miközben a hallgatók megfeledkeznek a fizikai aktivitás fontosságáról. Szükséges volna az egyén számára optimális egyensúly kialakítása ezen tevékenységek összhangba hozatalával. A negatív egészségügyi kimenetel, mely a testmozgás hiányából ered, jobbára megelőzhető az életmódmegváltoztatással. A hallgatók kevés időt fordítanak a testmozgásra szabad idejükben, mindeközben pedig sok időt töltenek üléssel. Teljesen tisztában vannak a testmozgás pozitív hatásaival, ezt igazolja is, hogy a megkérdezettek 75,8\%-a fontosnak vagy nagyon fontosnak tartja a fizikai aktivitás egészségre gyakorolt hatását. Viszont ha meg- 
nézzük, a férfiak közül a megkérdezettek majdnem fele (41,7\%) egyáltalán nem végez fizikai aktivitást a szabad idejében, de azok, akik végeznek testmozgást, ôk hetente átlagosan 120 percen keresztül aktívak, a nőknél pedig 3 hallgatóból egy teljesen passzív, az aktívak átlagosan hetente 100 percen keresztül mozognak intenzíven. Ezen eredmények alapján a fizikai aktivitás növelése azért is lenne fontos a hallgatók körében, mert korábbi kutatások igazolták, a rendszeres fizikai aktivitást végzők magabiztosabbak, könnyebben alakítanak ki barátságot, külsejükkel jobban meg vannak elégedve, kevésbé hajlamosak depresszióra. Az iskolai feladatok elvégzése kevésbé nyomasztják őket, jobb a tanulmányi eredményük (Kovács 2015). Társas kapcsolataikat tekintve barátaikkal könnyebben beszélik meg problémáikat. Egészségmagatartásuk is kedvezőbb és pozitív jövőperspektívával rendelkeznek, mint inaktív társaik (Aszmann 2000). Az egyetemi évek alatt kialakított testmozgással kapcsolatos szokások kihatással vannak a hallgatók rövid és hosszú távú egészségügyi állapotára (Sparling 2003). A mindennapi életbe beépített testmozgás hasznos módja az egyén állóképessége növelésének (Edwards \& Tsouros 2006) és mentális egészsége fenntartásának (Hallal et al. 2006; Kovács 2014).

A hallgatók nagyon pozitívan értékelték a testnevelést más tantárgyakhoz való viszonyában, 64,4\%-uk úgy véli, hogy egyenértékủ az iskolai képzés más területeivel, 23,7\%-uk pedig fontosabbnak tartja a többi tantárgynál (3. ábra). Tehát a testnevelés szerepét és pozitív hatásait elismerik a hallgatók. Viszont ha gyermekkorban nem alakul ki a testmozgás iránti vágy, akkor a későbbiekben igen csekély az esélye annak, hogy aktív felnőttekről, egyetemistákról beszélhessünk. Előfordul, hogy serdülőkorban, az egyetemista években fő́leg a lányok és nők fizikai aktivitással kezdenek el foglalkozni a külsejük miatt, amikor rövid idő alatt látványos eredményt szeretnének elérni. Amikor ez nem következik be, akkor feladják. Nincsenek tisztában azzal, ha egy kicsit is odafigyelnek a fizikai aktivitásukra és folyamatosan sikerül hetente 2-3 edzésen részt venniük, sokkal jobb lesz a közérzetük, önbizalmuk, állóképességük és persze kiegyensúlyozottabbak, nyugodtabbak lesznek azáltal, hogy endorfin szabadul fel a szervezetükben (Ahn \& Fedewa 2011; Peluso \& Guerra de Andrade 2005).

A Polar A300-as eszközzel követve a tíz hallgató napi aktivitását megállapítható, hogy átlagosan mindössze napi 5 óra 21 percet vannak mozgásban, azaz nem ülnek vagy fekszenek. Amin változtatni kellene, az nem is az átlagosan 8 óra 57 perc fekvés, alvással együtt, hanem a 8 óra 44 perc, amit hallgatóink ülő helyzetben töltenek. Ez betudható az óráknak, a vizsgákra való készülésnek, vagy egyszerúen a televíziózásnak, az „okos” eszközök használatának. Testmozgás hiányában érzékenység, ingerlékenység, idegesség, zárkózottság, levertség és a mentális funkciók csökkenése jelentkezhet. A hallgatók intenzív testmozgással eltöltött idejük napi szinten átlagosan négy perc!

Ennek meg kell változnia, hiszen ha ez így marad, és mire gyakorló pedagógusok lesznek, rossz példával szolgálnak diákjaiknak, így nem várhatjuk el a társadalomtól, hogy egészségesebb életmódot folytasson. A fiatalok sportolása, egészségvédelme kiemelten fontos a jövő generációk szempontjából, mindez különösen igaz a jövő pedagógusainak esetében is, hiszen ők nemcsak a saját maguk egészségéért felelnek, de 
tanítványaik számára is fontos mintát jelentenek. A családból hozott értékeket nekik kell tovább erősíteni, vagy azok hiányában, kialakítani. Ezért a testmozgás szerepe és jelentősége az egyetemi oktatás részéve kell hogy váljon. A minden évfolyamot érintő egyetemi tanterven történő változtatás révén lehetővé kell tenni a kurzushoz kötött heti rendszerességgel folytatott testmozgásos aktivitások végzését, mely során kreditpontokat gyüjthetnének a hallgatók. Ily módon lehetőség nyílik arra, hogy a hallgatók nemcsak üléshez kötött tevékenységet folytassanak, hanem aktív testmozgással gazdagodnának egyetemi mindennapjaik.

\section{Hivatkozott irodalom}

- Ahn, S. \& Fedewa, A. L. (2011). A meta-analysis of the relationship between children's physical activity and mental health. Journal of Pediatric Psychology, 36 (4), 385-397.

- Aszmann A. (2000). Fiatalok egészségi állapota és egészségi magatartása. Budapest, Országos Tisztifőorvosi Hivatal.

- Bailey, R. (2006). Physical education and sport in schools: A review of benefits and outcomes. Journal of School Health, 76 (8), 397-401.

- Barnett, L., Van Beurden, M. E., Morgan, P. J., Brooks, L. O. \& Beard, J. R. (2009). Childhood motor skill proficiency as a predictor of adolescent physical activity. Journal of Adolescent Health, 44 (3), 252-259.

- Blair, S. N. \& Hardman, A. (1995). Special issue: Physical activity, health and wellbeing an international scientific consensus conference. Research Quarterly for Exercise and Sport, 66 (4), 141-149.

- Blair, S. N., LaMonte, M. J. \& Nichaman, M. Z. (2004). The evolution of physical activity recommendations: How much is enough? American Journal of Clinical Nutrition, 79 (5), 913-920.

- Cliff, D., Okely, A., Smith, L. \& McKeen, K. (2009). Relationships between fundamental movement skills and objectively measured physical activity in preschool children. Pediatric Exercise Science, 21 (4), 436-449.

- Dunton, F. G., Whalen, C. K., Jamner, L. D., Henker, B. \& Floro, J. N. (2005). Using Ecologic Momentary Assessment to Measure Physical Activity during Adolescence. American Journal of Preventive Medicine, 29 (4), 281-287.

- Đorđić, V. \& Bala, G. (2006a). Fizička aktivnost dece predškolskog uzrasta. In Bala, G. (szerk.): Fizička aktivnost devojčica i dečaka predškolskog uzrasta (pp. 57-74). Novi Sad, Fakultet fizičke kulture.

- Edwards, P. \& Tsouros, A. D. (2006). Promoting physical activity and active living in urban environments: The role of local governments. Copenhagen, Denmark, World Health Organization, Regional Office for Europe.

- Hallal, P. C., Victora, C. G., Azevedo, M. R. \& Wells, J. C. (2006). Adolescent physical activity and health: A systematic review. Sports Medicine, 36 (12), 10191030 . 
- Haugen, T., Safvenbom, R. \& Ommundsen, Y. (2011). Physical activity and globalself-worth: The role of physical self-esteem indices and gender. Mental Health and Physical Activity, 4 (2), 49-56.

- Hernelahti, M., Kujala. U. \& Kaprio, J. (2004). Stability and change of volume and intensity of physical activity as predictors of hypertension. Scandinavian Journal of Public Health, 32 (4), 303-309.

- Horvat V., Mišigoj-Duraković, M. \& Prskalo, I. (2009). Body Size and Body Composition Change Trends in Preschool Children over a Period of Five Years. Collegium Antropologicum, 33 (1), 99-103.

- Kohl, H.W. (2001). III Physical activity and cardiovascular disease: evidence for a dose response. Medicine and Science in Sports Exercise, 33 (6), 472-83.

- Kovács K. (2013). Sportoló közösségekhez tartozás mint társadalmi védőfaktor. Educatio, (2), 264-270.

- Kovács K. (2014). Boldogító mozgás. A sportolás hatása a partiumi hallgatók szubjektív jóllétére, lelki edzettségére és egészségének önértékelésére. Kapocs, (2), 2-13.

- Kovács K. (2015). A sportolás mint támogató faktor a felsóoktatásban. Oktatáskutatók könyvtára 2. Debrecen, CHERD-H (ISBN 978-963-473-810-7).

- Kovács K. \& Perényi Sz. (2014). A sportolás és egészség. Kapcsolatok a fiatalok fizikai, mentális és szociális jóllétének szubjektív szintjével. In Nagy Á. \& Székely L. (szerk.): Másodkézböl. Magyar Iffúság 2012 (pp. 245-262). Budapest, Kutatópont.

- Mackintosh, A. K., Knowles, R. Z., Ridgers, D. N. \& Fairclough, T. S. (2011). Using formative research to develop CHANGE: a curriculum-based physical activity promoting intervention. BMC Public Health, 11 (831). doi:10.1186/1471-2458-11-831.

- Marshall, S. J., Biddle, S. J. H., Sallis, J. F., McKenzie, T. L. \& Conway, T. L. (2002). Clustering of Sedentary Behaviors and Physical Activity Among Youth: A CrossNational Study. Pediatric Exercise Science, 14 (4), 401-417.

- Martínez-González, M., Martínez, J., Hu, F., Gibney, M. \& Kearney J. (1999). Physical inactivity, sedentary lifestyle and obesity in the European Union. International Journal of Obesity and Related Metabolic Disorders, 23 (11), 1192-201.

- Mikalački, M.(2000). Teorija i metodika sportske rekreacije. Novi Sad, Fakultet fizičke kulture.

- Mišigoj-Duraković,M. (2006). Kinantropologija-biološki aspekti tjelesnog vježbanja. Zagreb, Kineziološki fakultet.

- Pantelić, S., Savić, Z. \& Ranđelović, N. (2008). Promena kardiovaskularnih fitnesa nakon realizacije programskih sadržaja fizičkih aktivnosti. Journal of Anthropological Society of Serbia, (43), 429-39.

- Peluso, M. A. \& Guerra de Andrade, L. H. (2005). Physical activity and mental health: The association between exercise and mood. Clinics, 60 (1), 61-70.

- Sacheck, J. M., Kuder, J. F. \& Economos, C. D. (2010). Physical fitness, adiposity, and metabolic risk factors in young college students. Medicine and Science in Sports and Exercise, 42 (6), 1039-1044. 
- Sinha, R., Fisch, G., Teague, B., Tamborlane, W.V., Banyas, B., Allen, K., ... Caprio, S. (2002). Prevalence of impaired glucose tolerance among children and adolescents with marked obesity. New England Journal of Medicine, 346 (11), 802-810.

- Sjogren, T., Nissinen, K. J., Jarvenpaa, S. K., Ojanen, M. T., Vanharanta, H. \& Malkia, E. A. (2006). Effects of a physical exercise intervention on subjective physical well-being, psychosocial functioning and general well-being among office workers: a cluster randomized-controlled cross-over design. Scandinavian Journal and Medicine Science in Sports, 16 (6), 381-90.

- Sparling,P.B. (2003). College physical education: An unrecognized agent of change in combating inactivity-related diseases. Perspectives in Biology and Medicine, 46 (4), 579-587.

- World Health Organization (2000). Obesity: preventing and managing the global epidemic; WHO Technical Report Series.

- World Health Organization (2002). The world health report: reducing risk, promoting bealth life. Geneva, World Health Organization.

- World Health Organization (2009). Global health risks: mortality and burden of disease attributable to selected major risks. Geneva, World Health Organization. 


\title{
Dobay BeÁtA
}

\section{Rekreációs sporttevékenységek a szlovák felnőtt lakosság körében}

\begin{abstract}
Absztrakt
Tanulmányunk célja bemutatni a felnőtt középkorosztály rekreációs sporttevékenységi lehetőségeit és a férfiak és a nők közötti különbséget Dél-Szlovákia három járásában (Komárom, Érsekújvár és Dunaszerdahely). A felmérés során kérdőívet alkalmaztunk, melyben segítségünkre volt a Granadai Egyetem szakemberei által összeállított kérdőív. A kérdőívet 742 fő töltötte ki, közülük 339 férfi és 403 nő. A külföldi és belföldi szakirodalmi áttekintésen túl a kérdőívet különböző programok segítségével dolgoztuk fel. A GeoGebra és SPSS-programcsomag segítségével Chi-négyzet-próbát és Pearson-féle korrelációt alkalmaztunk. Az átlagéletkor a nők esetében 37,2 év a férfiaknál ez 36,5 év. Felmértük a rekreációs sporthelyszínekhez való eljutást: a férfiak 72,9\%-a rendelkezik olyan közlekedési eszközzel, mellyel eljut a helyszínre. Ennél a kérdésnél szignifikáns $(\mathrm{p}<0,01)$ különbség volt a két nem között. Megkérdeztük, hogy anyagilag menynyi pénzt hajlandók rekreációs sporttevékenységre ráfordítani. Eredményeink szerint a férfiak többet hajlandók anyagilag rekreációs sportra költeni. Itt is szignifikáns ( $p<0,01)$ különbség volt a két nem között. Összehasonlítottuk a nemek közti különbségeket számos rekreációs sporttevékenységgel kapcsolatos kérdéskörben. Javaslataink közé tartozik, hogy felhívjuk a figyelmet a természetben végezhető fizikai aktivitások alkalmazhatóságára a rekreációs tevékenységeik során.
\end{abstract}

\section{Bevezetés $^{1}$}

A sport jelentősége az ember számára egyre jobban beépül a köztudatba, melyet számos kutatási eredmény is alátámaszt. A sporttevékenység az egészség egyik alappillére (Ihász \& Rikk 2010; Fügedi 2009; Borbély \& Müller 2008; Bendíková 2014). Szlovákiában epidemológiai felmérést végeztek „IDEA Slovensko” (Dukát et al. 2007) megnevezéssel. A kutatás eredményei szerint a lakosság 46,3\%-a volt tekinthető elhízottnak, a nőknél ez az érték magasabb volt, 56,1\%-ot tett ki. A körzeti orvosnál megjelenő nők közül minden harmadik túlsúllyal rendelkezett (34,7\%). Az egészségi állapot romlása kihat a munkaképességre is. Az országban 2011-ben több mint 700000 felnőtt volt munkaképtelen, ebből 361276 férfi és 366034 nő, ami 1,2\%-os különbséget mutat a két nem között (Cvopová 2012).

1 A tanulmány része a VEGA-programnak (száma 1/0376/14). 
A munkaképtelenség megelőzésénél egyik alapvető tényező lehet a megfelelően felhasznált szabad időben végezhető rekreációs jellegű sporttevékenység. A tanulmányunkban a felnőtt korosztály rekreációs sporttevékenységeinek jelenlétét mutatjuk be Szlovákiában. A felnőttkor az életünk egyik leghosszabb időszakának mondható. Končeková (2010) szerint ezt a kort három szakaszra oszthatjuk fel: a fiatal felnőttkor, mely a 18/20-30 éves korig tart, majd a középkorosztály 30-tól 45-éves korig, majd az idősebb felnőttkor, mely a 45-től a 65-éves korig tart. Ebben az időszakban a felnőtt korosztálynál a fizikai teljesítőképesség a csúcspontját éri el. Mi a felnőttkor középkorosztályát vettük célul. Ennél a korosztálynál fontos tényező lenne a megfelelő egyensúly megtalálása a munka és az egészség között. Ennél a korosztálynál történik a családalapítás (szociális tényező), mely magával hozza az anyagi háttér biztosítását (gazdasági tényező) a család számára. Nem szabad megfeledkezni a fizikai teljesítőképesség fenntartásáról, melyet a különböző testmozgások megfelelő alkalmazásával érhetünk el.

A felnőtt korosztály rekreációs szokásairól Bánhidi (2016) Rekreológia könyvében így ír: „a felnőtté válás és a családalapítás a rekreáció tekintetében jelentős változásokat eredményez" (Bánhidi 2016: 98). A felnőttek a rekreációjuk során önállóan saját érdekeiket képviselve választanak a rekreációs programokból. Egyben megkívánják a sokrétű, széles választékú rekreációs programok kínálatát. A családos felnőtt korosztály számára a közös élmény és együttműködés, összetartozás, egymás iránti felelősség vállalás kerül az előtérbe (Bánhidi 2016).

Ezenfelül nem szabad megfeledkeznünk az aktív fizikai sporttevékenységről sem, mely az egészségünk megtartásához szükséges. Számos kutató ajánlását mutatjuk be a felnőttek számára. Az amerikai kutatók fizikai aktivitásra való ajánlása a felnőttek számára: aerob tevékenység 300 perc közepes intenzitással, vagy 150 perc intenzív sporttevékenység hetente. Ezenfelül még ajánlják az erősítő jellegű gyakorlatokat és $2 \times$ hetente legalább átmozgatni minden főbb izomcsoportot. Az Európai Unió fizikai aktivitás ajánlása pedig a következő: legalább 30 perc/5 nap/1 hét közepes intenzitású testmozgás, vagy 20 perc/3 nap/1 hét intenzív testmozgás. A főbb izomcsoportok erősítése legalább 2-3 nap/1 hét (WHO 2002).

A felnőtt korosztály számára a testmozgás a következő főbb célokat biztosítja: az egészség megőrzése, az öregedés megelőzése, a mozgásképesség szinten tartása (Šimonek 2007). Šimonek (2007) a 19-30 évesek számára 3-4 alkalmat, 4-6 órát hetente, a 31-40 éveseknek 4-5 alkalmat, 5-7 órát hetente, míg a 41-55 évesek számára 4-6 alkalmat, összesen 6-8 órát hetente ajánl. A felnőttek számára Szlovákiában egy kutatás az edzettség növelésére, az egészség megtartására és a testtömeg csökkentésére irányuló motivációkat tárta fel (Labudová 2008). Egy másik kutatás eredményeként Szlovákia minden kerületében (nyolc kerület) a nők esetében az első helyen az aerobik, a második helyen leggyakrabban a gyógytorna és a harmadik helyen a pilates helyezkedett el (Labudová 2008).

A Nemzetközi Egészségügyi Világszervezet (WHO 2004) ajánlása alapján a hoszszú élet fenntartásához elengedhetetlen az aktív - megfelelő intenzitású - rendszeres 
fizikai tevékenység. A mozgás kedvező hatást fejti ki a lelki és a testi jóllétre, befolyásolja az életminőséget (Fox 1999; Prichard \& Tiggermann 2008), melyhez hozzá tartozik a stressz, a szorongás és a depresszió csökkentése (Scully et al. 1998; Bălţătescu \& Kovács 2012; Bălţătescu \& Kovács 2013; Kovács 2014; Kovács 2015).

A munka célja bemutatni az adott régió felnőtt lakossága közül a legaktívabb korosztálynak a középkorúaknak számító felnőttek rekreációs sporttevékenységeit. A kutatás Dél-Szlovákia három járásában (Komárom, Érsekújvár és Dunaszerdahely) történt.

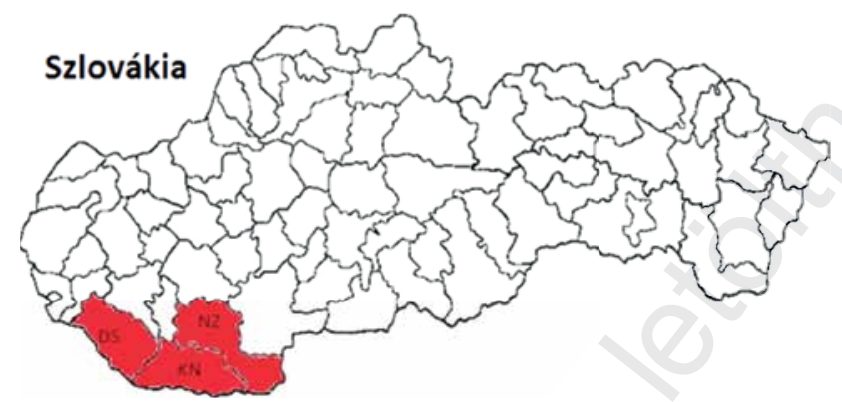

1. ábra. Szlovákia térképe a kutatásba bekapcsolódó három járás (Komárom, Érsekújvár, Dunaszerdahely) (www.google.hu alapján saját szerkesztés)

\section{Feltételezéseink:}

- feltételezzük, hogy a férfiak legalább 20\%-kal egészségesebbeknek, fizikailag edzettebbeknek tartják magukat a nökkel szemben,

- feltételezzük, hogy a nemek között különbség lesz a sporttevékenységek kiválasztásában,

- feltételezzük, hogy a férfiak többet költenek anyagilag rekreációs sporttevékenységre, mint a nôk.

\section{Módszerek}

A felmérés során a következő módszereket alkalmaztuk: a Granadai Egyetem szakemberei által összeállított és validált „Mozgás és egészség” kérdőívet. ${ }^{2}$ A kérdőívet 742 fô töltötte ki, közülük 339 férfi és 403 nő volt. Az adatok felvételét 2014-ben végeztük, majd az eredményeket 2015-2016-ban folyamatosan dolgoztuk fel. A külföldi és belföldi szakirodalmi áttekintésen túl a kérdőívet különböző programok segítségével dolgoztuk fel. Alkalmaztuk a Chi-négyzet megállapításánál a GeoGebra programot, a Pearson-korreláció esetében az Excel és az SPSS-program kalkulátorait.

\footnotetext{
${ }^{2}$ http://www.ugr.es/
} 


\section{A kutatás eredményei}

A kutatásban részt vevő́k átlagéletkora a férfiaknál $36,5 \pm 4,54$, a nők esetében 37,2 $\pm 3,04$ év. A férfiak esetében a testsúly $89 \pm 7,9 \mathrm{~kg}$, a nőknél $65,3 \pm 6,8 \mathrm{~kg}$. A férfiak testmagassága 179,6 $\pm 6,3 \mathrm{~cm}$, a nők testmagassága 167,9 $\pm 3,2 \mathrm{~cm}$. A kutatásban részt vevők egyetemi, fôiskolai és középiskolai végzettséggel rendelkeztek. Mindenki családi kötelékben élt (a családban minimum egy és maximum három gyerekkel). A kutatásban részt vevők testtömegindexe (BMI - Body Mass Index) a következőképpen alakult: a férfiak esetében $24,9 \pm 3,1$, a nők esetében 24,6 $\pm 3,9$, a WHR-index (Waist to Hip Ratio) a férfiak esetében 98-as, míg a nőknél 86-os értéket kaptunk, ami a férfiak esetében megfelelő, a nőknél egy kissé, egy értékkel túllépi a megfelelő mértéket.

1. táblázat. A megkérdezettek hogyan értékelik az egészségüket?

$(\mathrm{N}=742$, férfi $\mathrm{n}=339$, nő $\mathrm{n}=403)$

\begin{tabular}{|c|c|c|c|c|c|c|c|}
\hline \multicolumn{10}{|c|}{ Hogyan értékeli az egészségét? } \\
\hline \multirow{2}{*}{ Férfi } & rossz & kielégítő & jó & nagyon jó & kitűnő & $\chi^{2}$ & p \\
\cline { 2 - 7 } & $2,7 \%$ & $3,2 \%$ & $19,2 \%$ & $29,2 \%$ & $45,7 \%$ & \multirow{2}{*}{177.8421} & \multirow{2}{*}{0.01} \\
\hline Nő & $8,2 \%$ & $26,1 \%$ & $36,5 \%$ & $17,1 \%$ & $12,2 \%$ & & \\
\hline
\end{tabular}

Forrás: saját szerkesztés

Az egészségüket ekképpen értékelték: több férfi $(45,7 \%, \mathrm{n}=155)$ mint nő $(12,2 \%$; $\mathrm{n}=49$ ) értékeli jelenleg az egészségét kitúnőnek, ez $\left(\chi^{2}=177,8421\right.$; df-4), ami szignifikáns különbséget $(\mathrm{p}<0,01)$ mutat a két nem között ebben a kérdésben (1. táblázat). A következő legnagyobb különbség a kielégítő választ adók között volt: míg a férfiak közül csak 3,2\% ( $\mathrm{n}=11)$, addig a nők 22,9\%-kal többen válaszolták, ami 26,1\%-ot tett ki. A European Health Interview Survey (EHIS) által végzett magyarországi kutatásban a középkorú felnőttek 80\%-a volt elégedett az egészségével és egészségi állapotával. A férfiak $(65,2 \%)$ itt is jobbnak értékelték az egészségüket és egészségi allapotukat, mint a nők (58\%) (KSH 2015).

2. táblázat. Milyen a fizikai állapota? $(N=742$, férfi $n=339$, nő $n=403)$

\begin{tabular}{|c|c|c|c|c|c|c|c|}
\hline \multicolumn{10}{|c|}{ Milyen a fizikai állapota? } \\
\cline { 1 - 6 } & rossz & kielégítő & jó & nagyon jó & kitúnő & $\chi^{2}$ & p $<$ \\
\cline { 2 - 6 } & $5,3 \%$ & $13,2 \%$ & $29,1 \%$ & $20,9 \%$ & $31,5 \%$ & \multirow{2}{*}{103.84} & \multirow{2}{*}{0.01} \\
\hline Nő & $22,1 \%$ & $32,3 \%$ & $24,6 \%$ & $11,4 \%$ & $9,6 \%$ & & \\
\hline
\end{tabular}

Forrás: saját szerkesztés

A fizikai állapotukat kitűnőnek vallotta a férfiak 31,5\%-a ( $\mathrm{n}=107)$, és csak a nők 9,6\%-a ( $n=39)$ válaszolta ugyanezt. A nők esetében rossz fizikai állapottal rendelkezett a megkérdezettek 22,1\%-a ( $=89)$, ami 16,8\%-kal több, mint a férfi válaszadók 
esetében $(5,3 \%, \mathrm{n}=18)$. A nemek között ebben a kérdésben is szignifikáns különbséget kaptunk $\left(\chi^{2}=177,8421 ; p<0,01\right)(2$. táblázat). Szignifikáns korrelációs kapcsolatot találtunk a férfiaknál $(r=0,8300)$ és a nőknél $(r=0,7193)$ is az egészségi állapot és a fizikai állapot között.

Az egészségi és fizikai állapot kérdések után felmértük azokat a sporttevékenységeket, melyeket leginkább végeznek szabad idejükben a megkérdezettek. A nők esetében leginkább a táncos aerobikos tevékenységek dominálnak: a megkérdezetteknek 30,16\%-a ( $\mathrm{n}=122)$ az ilyen jellegú mozgástevékenységet végzi. Legtöbben az aerobikot választották $(16,45 \%, \mathrm{n}=66)$, majd ezt követte a kerékpározás 13,85\%-kal $(\mathrm{n}=56)$, a zumba $(13,71 \% ; n=55)$, úszás $(12,12 \% ; n=49)$. A nőknél jellemző az olyan sporttevékenységek választása, amely a mozgás esztétikai élményét biztosítja számukra. Többen, 21,35\%-uk ( $\mathrm{n}=86)$ az egészségük megőrzésére irányuló aktivitást választottak, mint a jóga $(8,8 \% ; n=35)$, gyógytorna $(8,08 \% ; n=3)$, pilates $(4,47 \% ; n=18)$ (3. táblázat).

3. táblázat. A nők kedvenc rekreációs sporttevékenységei

(nó $\mathrm{n}=403$ )

\begin{tabular}{|c|l|c|}
\hline \multicolumn{2}{|c|}{ A nők kedvenc sporttevékenységei } \\
\hline 1 & aerobik & $16,45 \%$ \\
\hline 2 & kerékpározás & $13,85 \%$ \\
\hline 3 & zumba & $13,71 \%$ \\
\hline 4 & úszás & $12,12 \%$ \\
\hline 5 & futás & $11,12 \%$ \\
\hline 6 & jóga & $8,80 \%$ \\
\hline 7 & görkorcsolyázás & $8,23 \%$ \\
\hline 8 & gyógytorna & $8,08 \%$ \\
\hline 9 & pilates & $4,47 \%$ \\
\hline 10 & nordic walking & $3,17 \%$ \\
\hline
\end{tabular}

Forrás: saját szerkesztés

A férfiak esetében 33,49\% ( $\mathrm{n}=114$ ) választotta a labdajátékokat. A legnépszerúbb a labdarúgás $(16,75 \% ; n=57)$, majd ezt követi a most igen divatos erősítés a fitnesztermekben $(15,49 \% ; n=53)$. A nőknél 2. helyen és a férfiaknál is 3. helyen a kerékpározás $(15,34 \% ; n=52)$ helyezkedik el (4. táblázat). Míg a futást a férfiak a negyedik $(13,93 \%$; $\mathrm{n}=47$ ), addig a nők az ötödik helyen említették. Az úszás pedig a nőknél a negyedik helyen $(12,12 \% ; n=49)$, a férfiaknál az ötödik helyen $(12,05 \% ; n=41)$ helyezkedik el. Ez azzal is magyarázható, hogy a testnevelésoktatáson belül az óvodától kezdve a középiskolai és egyetemi képzésen belül is találkoznak a tanulók rendszeres úszásoktatásával. Szlovákiában lehetôség van óvodában legalább egyszer, alsó tagozaton harmadikban, felső tagozaton ötödikben és a középiskola első évfolyamában egyhetes 
úszásoktatáson részt venni. Ezt az oktatási állami program testnevelésre vonatkozó előírásai biztosítják: ISCED0, ISCED1, ISCED2, ISCED3. ${ }^{3}$ Az egyetemeken választható tantárgyként szerepel az úszásoktatás. Vannak szakok, mint a testnevelés- és pedagógusképzés, ahol ez kötelező. Ezek a tényezők mind hozzájárulnak ahhoz, hogy sokan tudnak úszni.

Az eredmények ebben az esetben is azt mutatják, hogy nemcsak a fiatal és az idősebb korosztálynál, de a felnőtt középkorosztálynál is a nők inkább az egyéni sportokat kedvelik, esztétikai irányzattal $\left(\chi^{2}=33,2323 ; \mathrm{p}<0,01\right)$, míg a férfiak a dinamikus és kondicionális jellegú mozgástevékenységeket keresik $\left(\chi^{2}=36,3239 ; \mathrm{p}<0,01\right)$.

4. táblázat. A férfiak kedvenc rekreációs sporttevékenységei (férfi $\mathrm{n}=339$ )

\begin{tabular}{|r|l|r|}
\hline \multicolumn{2}{|c|}{ A férfiak kedvenc sporttevékenységei } \\
\hline 1 & labdarúgás & $\mathbf{1 6 , 7 5 \%}$ \\
\hline 2 & fitnesz & $15,49 \%$ \\
\hline 3 & kerékpározás & $15,34 \%$ \\
\hline 4 & futás & $13,93 \%$ \\
\hline 5 & úszás & $12,05 \%$ \\
\hline 6 & kosárlabda & $6,73 \%$ \\
\hline 7 & tenisz & $5,16 \%$ \\
\hline 8 & nordic walking & $5,01 \%$ \\
\hline 9 & görkorcsolyázás & $4,69 \%$ \\
\hline 10 & röplabda & $4,85 \%$ \\
\hline
\end{tabular}

Forrás: saját szerkesztés

A rekreációs mozgástevékenységek végzésének egyik fontos tényezője az anyagi háttér. A következő kérdésekben arra kerestük a választ, hogy milyen a megkérdezettek gazdasági helyzete, milyen anyagi ráfordítást tudnak áldozni erre a célra. Dobay és Bendíková (2014) kutatási eredményei azt mutatták, hogy az egyetemi végzettségú férfiak és nók (menedzserek, vállalkozók, jogászok és orvosok) is egyaránt tudnak nagyobb pénzösszeget fizetni a rekreációs sporttevékenységekre.

${ }^{3}$ International Standard Classification of Education (www.minedu.sk). 
5. táblázat. Mennyi pénzt költ havonta sporttevékenységre?

$(\mathrm{N}=742$, férfi $\mathrm{n}=339$, nő $\mathrm{n}=403)$

\begin{tabular}{|c|c|c|c|c|c|c|c|}
\hline \multicolumn{7}{|c|}{ Mennyi pénzt költ havonta sporttevékenységre? } \\
\hline \multirow{2}{*}{ Férfi } & $\mathbf{1 0} €$ & $\mathbf{2 0} €$ & $\mathbf{3 0} €$ & $\mathbf{4 0} €$ & $\mathbf{5 0 €}$ & $\chi^{\mathbf{2}}$ & $\mathrm{p}<$ \\
\cline { 2 - 7 } & $41,9 \%$ & $26,3 \%$ & $11,5 \%$ & $6,5 \%$ & $13,9 \%$ & \multirow{2}{*}{17.0274} & \multirow{2}{*}{0.01} \\
\hline Nő & $36,2 \%$ & $23,3 \%$ & $20,1 \%$ & $10,7 \%$ & $9,7 \%$ & & \\
\hline
\end{tabular}

Forrás: saját szerkesztés

$\mathrm{Az}$ anyagi ráfordítást két idődimenzió mentén is megvizsgáltuk, megkérdeztük a kutatásban részt vevőket, hogy mennyi pénzt hajlandók havonta és évente rekreációs sporttevékenységre fordítani. A férfiak többet hajlandók anyagilag rekreációs sportra költeni. Legtöbben 10 euróig hajlandók költeni, a férfiak közül 41,9\% (n = 142), míg a nők 36,2\%-a ( $n=146)$. A férfiak közül 40 euró feletti összeget a megkérdezettek 13,9\%-a ( $\mathrm{n}=47)$ választott, a nők esetében ez 9,7\%-ot $(\mathrm{n}=39)$ tett ki. Itt is szignifikáns különbség volt a két nem között $\left(\mathrm{p}<0,01, \chi^{2}=17,0274\right.$; df-4) (5. táblázat).

$\mathrm{Az}$ éves rekreációs sporttevékenységekre való anyagi finanszírozásnál nagy különbség volt a válaszadók között a $200 €$ feletti költés esetében: a férfiak 45,1\%-a ( $n$ = 153), míg a nők közül 25,5\%-kal kevesebben, 19,6\% (n = 79) hajlandó ennyi pénzt ráfordítani. A nők esetében $100 €$-t hajlandók a legtöbben költeni, ami 49,9\%-ot ( $\mathrm{n}=201)$ tett ki, a két nem válaszai közötti különbség szignifikáns eredményt adott $\left(\chi^{2}=165,5231 ; \mathrm{p}<0,01 ;\right.$ df-3) (6. táblázat). Az ország gazdasági válságának következményei ebben a kérdésben is megmutatkozott, a munkahelyek bizonytalansága (5,64\%), a munkanélküliség (5,13\%), a létfenntartáshoz szükséges magasabb kiadások $(12,05 \%)$ a szocio-gazdasági helyzet viszonylatában, melyet a Szlovák Köztársaság lakossága szociális helyzetképének 2010-es jelentése tartalmaz (Správa 2011). ${ }^{4}$

6. táblázat. Mennyit költ évente sporttevékenységre? $(\mathrm{N}=742$, férfi $\mathrm{n}=339$, nő $\mathrm{n}=403$ )

\begin{tabular}{|c|c|c|c|c|c|c|}
\hline \multicolumn{7}{|c|}{ Mennyit költ évente sporttevékenységre? } \\
\hline & $50 €$ & $100 €$ & $200 €$ & $200 €$ felett & $\chi^{2}$ & $\mathrm{p}<$ \\
\hline Férfi & $6,8 \%$ & $10,9 \%$ & $37,2 \%$ & $45,1 \%$ & \multirow{2}{*}{165.523} & \multirow{2}{*}{0.01} \\
\hline Nő & $14,1 \%$ & $49,9 \%$ & $16,4 \%$ & $19,6 \%$ & & \\
\hline
\end{tabular}

Forrás: saját szerkesztés

Felmértük a rekreációs sporthelyszínekhez való eljutást. A férfiak 72,9\%-a (n = 247) autóval közelíti meg azokat a helyszíneket, ahol aktív fizikai sporttevékenységet folytatnak. Ennél a kérdésnél szignifikáns ( $\left.\mathrm{p}<0,01 ; \chi^{2}=84.8584 ; \mathrm{df}-3\right)$ különbség volt a két nem között (7. táblázat).

\footnotetext{
4 www.employment.gov.sk
} 
7. táblázat. Autóval való eljutás a sporttevékenységek helyszínére $(\mathrm{N}=742$, férfi $\mathrm{n}=339$, nô $\mathrm{n}=403)$

\begin{tabular}{|c|c|c|c|c|c|c|}
\hline \multicolumn{7}{|c|}{ Autóval való eljutás a sporttevékenységek helyszínére } \\
\hline \multirow{2}{*}{ Férfi } & nem & néha & gyakran & igen & $\chi^{2}$ & p $<$ \\
\cline { 2 - 6 } & $1,2 \%$ & $6,2 \%$ & $19,8 \%$ & $72,9 \%$ & \multirow{2}{*}{84.8584} & 0.01 \\
\hline Nő & $10,7 \%$ & $22,8 \%$ & $21,6 \%$ & $44,9 \%$ & & \\
\hline
\end{tabular}

Forrás: saját szerkesztés

\section{Összegzés}

A feltételezéseinkre kapott válaszoknál az első hipotézisünk beigazolódott, mely szerint a férfiak legalább 20\%-kal jobb egészségi és fizikai állapotot fognak feltüntetni, mint a nők. Az eredményeink azt mutatták, hogy a kutatásunk során a nők közül 33,5\%-kal kevesebben jelölték meg a kiváló egészségi állapotot, mint a férfiak. A fizikai állapot terén pedig a nők körében 21,9\%-kal kevesebben mondták, hogy kiváló a fizikai állapotuk, mint azt a férfiak tették. Korrelációs kapcsolatot találtunk a férfiaknál ( $r=0,8300)$ és a nőknél $(r=0,7193)$ is az egészségi állapot és a fizikai állapot között. A második feltételezésünk is beigazolódott, hisz a férfiak leginkább a labdajátékokat választják sporttevékenységül, számukra fontos a csapatban való együttlét, a dinamikus és a kondicionális mozgástevékenységeket részesítik előnyben. A nők inkább egyéni, táncos, egészséget megőrző, preventív mozgástevékenységeket végeznek. Számukra fontos a mozgás kivitelezésének esztétikai öröme.

A következő feltételezésünknél, ahol az anyagi ráfordításra kérdeztünk rá, a feltételezésünk szintén beigazolódott, hisz mind a két esetben, a havonta és az évente ráfordított összeg esetében, a férfiak hajlandók többet költeni a rekreációs sporttevékenységekre. Míg a havi költségnél 50 € felett a két nem között csak 4,2\% különbség volt a férfiak javára, ellenben az évente 200 € feletti kiadásnál már a két nem között 25,5\% különbség volt, szintén a férfiak javára.

A kutatásunk eredményei alapján elmondhatjuk, hogy a Dél-Szlovákia három járásában végzett felmérés alapján a válaszadó felnőtt középkorú férfiak egészségesebbnek és fizikailag edzettebbnek érzik magukat. A férfiak leginkább a labdajátékokat űzik, többet hajlandók költeni rekreációs sporttevékenységre, és leginkább autóval közelítik meg a sportolásra alkalmas helyszínt. A nők leginkább egyéni, egészségmegőrző, rekreációs sporttevékenységeket választanak. Javaslataink közé tartozik, hogy a felnőtt középkorosztálynál fontos a felvilágosítás az egészség megőrzéséről az újszerű rekreációs sporttevékenységek alkalmazásával. Fontos felhívni a figyelmet a természetben végezhető fizikai aktivitások alkalmazhatóságára a rekreációs tevékenységek során. A felnőttek számára mindig biztosítsunk újszerű, számukra kihívást jelentő mozgástevékenységeket. 


\section{Hivatkozott irodalom}

- Bălţătescu, S. \& Kovács K. (2012). Sport Participation and Subjective Well-being among University Students in the Hungarian-Romanian-Ukrainian Cross-border area. In Pusztai G., Hatos, A. \& Ceglédi T. (eds.): Third Mission of Higher Education in a Cross-Border Region. Educational Research in Central and Eastern Europe I. (pp. 134-148). Debrecen, CHERD-H, University of Debrecen.

- Bălţătescu, S. \& Kovács K. (2013). Sport and subjective well-being among Romanian and Hungarian students. The mediation of resilience and perceived health. In Zamfir, E. \& Maggino, F. (eds.): The European Culture for Human Rights: The Right to Happiness (pp. 174-191). Newcastle, Cambridge Scholars Publishing.

- Bánhidi M. (2016). Rekreológia. Budapest, Magyar Sporttudományi Társaság (ISBN 978-615-5187-08-7, 97-100).

- Bendíková, E. (2014). Lifestyle, physical and sports education and health benefits of physical activity. European Researcher: International Multidisciplinary Journal, 69 (2-2), 343-348.

- Borbély A. \& Müller A. (2008). A testi-lelki harmónia összefüggései és módszertana. Budapest, Professzorok az Európai Magyarországért Egyesület.

- Cvopová, A. (2012). Správa o zdravotnom stave obyvatel'stva SR za roky 20092011. Vydané, 16 (24). Forrás: http://www.nczisk.sk/Documents/aktuality/sprava_ zdravotnom_stave.pdf. Utolsó látogatás: 2016. 08. 10.

- Dobay, B. \& Bendíková, E. (2014). Športové a rekreačné aktivity v životnom štýle dospelých. Exercitatio Corporis-Motus-Salus, 6 (2), 19-31.

- Dukát, A., Lietava, J. \& Krahulec, B. (2007). Epidemiológia nadváhy a obezity na Slovensku. Via practica, 5 (3), 1-4.

- Fox, K. R. (1999). The Influence of physical activity on mental wellbeing. Public Health Nutrition, 2 (3), 411-418.

- Fügedi B. (2009). A sport, mint az egészségfejlesztés, életminőség-javítás eszköze. In Szatmári Z. (szerk.): Sport, életmód, egészség (pp. 919-926). Budapest, Akadémiai Kiadó.

- Ihász F. \& Rikk J. (2010). Egészségfejlesztés. Győr, szerzői kiadás.

- Končeková, L. (2010). Vývinovápsychológia. Prešov, Prešovská Univerzita (ISBN 978-807-165-811-5).

- Kovács K. (2014). Boldogító mozgás. A sportolás hatása a partiumi hallgatók szubjektív jóllétére, lelki edzettségére és egészségének önértékelésére. Kapocs, (2), 2-13.

- Kovács K. (2015). A sportolás, mint támogató faktor a felsöoktatásban. Oktatáskutatók könyvtára 2. Debrecen, CHERD-H (ISBN 978-963-473-810-7).

- Labudová, J. (2008). Preferenciatelovýchovných a športovýchčinností v športe pre všetkých v SR. Telesnávýchova छ̋ šport, physical education and sport, 18 (2), 7-11.

- Prichard, I. \& Tiggermann, M. (2008). Relations among exercise type, self-objectification, and body-image in the fitness centre environment: The role of reasons for exercise. Psychology of Sport and Exercise, (9), 855-866. 
- Šimonek, J. (2007). Celoživotná pohybová aktivita prezdravie. In Labudová,J. (ed.): Obsahovábáza v programešport a zdravie (pp. 30-31). Bratislava, UK FTVŠ.

- Scully, D., Kremer, J., Meade, M. M., Graham, R. \& Dudgeon, K. (1998). Physical exercise and psychological welbeing. Artical Review. British Journal of Sport Medicine, (32), 111-120.

\section{Dokumentumok}

- KSH (2015). Európai lakossági egészségfelmérés 2014. Statisztikai Tükör, (29), 1-9.

- Správa o Sociálnej Situácii Obyvatelstva Slovenskej Republiky Za Rok 2010; 2011 (2011). Bratislava: Ministerstvo práce, sociálnych vecí a rodiny Slovenskej Republiky. Forrás: https://www.employment.gov.sk/sk/ministerstvo/vyskum-oblasti-pracesocialnych-veci-analyticke-centrum/spravy-socialnej-situacii-obyvatelstvaslovenskej-republiky.html. Utolsó letöltés: 2016.08.10.

- Štátny vzdelávací program ISCED 0 - predprimárne vzdelávanie. ISCED1, ISCED2, ISCED3 (2008). Bratislava: MŠ, 2008. Forrás: www.minedu.sk. Utolsó letöltés: 2016. 08. 10.

- WHO (2002). Hýbte sa pre zdravie. Forrás: http://www.who.int/moveforhealth/en. Utolsó letöltés: 2015. 02. 12.

- WHO (2004). Global Strategy on Diet, Physical Activity and Health. 57th World Health Assembly. Forrás: http://www.who.int/diet-physicalactivity/strategy/eb11344/ strategy_engkish_web.pdf. Utolsó letöltés: 2015.02.12. 


\title{
Greba Ildikó, Greba Anna
}

\section{A testnevelés és a sport presztízshelyzete Kárpátalja magyar középiskoláiban}

\begin{abstract}
Absztrakt
A rendszerváltás után eltelt 25 év alatt az ukrán közoktatásban óriási változások történtek. Ezek az átalakítások jelenleg is zajlanak. Ezen változások tükrében, amelyek az iskoláskorú gyermekek életében, ha csak közvetetten is, de döntő szerepet töltenek be, felkeltette érdeklődésünket a sport és a testnevelés presztízsének vizsgálata iránt. Felmérést végeztünk a kárpátaljai magyar iskolák tanulói körében azzal a céllal, hogy felderítsük, ők hogyan viszonyulnak a testneveléshez és a sporthoz, a testnevelés tantárgy milyen helyet foglal el az életükben és milyen tényezők befolyásolják ezeket $(\mathrm{N}=108)$.

A vizsgálat eredményei azt mutatják, hogy a testnevelésórák és a testnevelést tanító pedagógusok megítélése kedvező a tanulók körében. A testnevelésórán kívüli sportolást illetően azt láthatjuk, hogy a tanulók többsége sportol rendszeresen, igaz, hobbiszinten. A nemek közt azonban eltérés van a fiúk javára a sportolási szokások tekintetében. Következésképpen a tanulók sportolási tevékenysége nemcsak irányított, szervezett keretek között valósul meg, hanem öntevékeny szabadidősport formájában is realizálódik.

Összességében elmondhatjuk, hogy a kárpátaljai iskolások körében a sport és a testnevelés presztízse magas, hiszen az órák iránti attitűdök döntően pozitívak, a rendszeresen, heti több alkalommal sportoló diákok aránya magas.
\end{abstract}

\section{Bevezetés}

1991-ben, Ukrajna független állammá való kikiáltását követően az oktatásirányítási struktúra teljesen új irányt vett. A szovjet érából átöröklött oktatási irányzatokat fel kellett hogy váltsa az új ukrán nemzeti alapokra épített oktatáspolitika (Orosz 2005; Kovács 2014a). 25 év alatt Ukrajnában három nemzeti alapprogramot fogadtak el: 1998-ban, 2009-ben és 2011-ben. Az oktatási reformtörekvések többé-kevésbé sikerültek, de a változtatások legjobban a tanárokat, diákokat, szülőket, iskolafenntartókat érintette. A tantervkészítőkre, a gyakorló testnevelő tanárokra óriási felelősség hárult az új nemzeti alapprogram kidolgozásában. 1998-ban megjelent az 1-11. osztályra kidolgozott testnevelési program, majd 2001-ben az 1-12. osztályra vonatkozó testnevelési tanterv, a kormányváltás után, 2009-ben az újabb oktatási reformokat követően ismét az 1-11. osztályos tanterv lépett életbe, amely 2011-ig volt érvényben. Ukrajnában bevezették minden évfolyamon a heti három testnevelésórát (Módszertani útmutatók...). E változások, melyek az iskoláskorú gyermekek életében, ha csak közvetetten 
is, de döntő szerepet töltenek be, felkeltették érdeklődésünket a sport és a testnevelés presztízsének vizsgálata iránt.

Az iskolai testnevelés és sport azon tantárgyak egyike, amelyek csak nehézségek árán tudtak alkalmazkodni a központilag előirt tantervek anyagához és követelményrendszeréhez. A helyi tervezés megteremtette annak lehetőségét, hogy reális, megvalósítható tervek készüljenek, figyelembe véve a tantárgy központi kerettantervekben megfogalmazott legfő́bb értékeit és céljait. A testnevelés jelenét és jövőjét alapvetően befolyásolja, hogy a testnevelô tanárok milyen hatékonysággal képviselik a tantárgy értékeit a helyi tervezés szintjein. Ahhoz, hogy a testnevelés legfóbb lényege - az egészséges életmódra nevelés - a gyakorlatot múködtetô elvvé váljék, az iskolai testnevelés és sport értékhordozó szerepét ezen a szinten is ki kell nyilvánítani. Úgy is fogalmazhatnánk, hogy a pedagógiai program olyan iránytú, amely megmutatja, az iskola milyen irányba halad, milyen jövőt kínál a felnövekvő generáció számára fontos „tantárgynak", az iskolai testnevelésnek és sportnak (Rétsági 2001).

Szent-Györgyi Albert 1930 novemberében az Országos Testnevelési Tanács kongresszusán a következőket mondta a sportról: „A sport, az nemcsak testnevelés, hanem a léleknek is a legerőteljesebb és legnemesebb nevelő eszköze. A sport fogalma azonban nem tévesztendő össze puszta testi ügyességgel, a rekordhajhászással, a nyereségvadászással és legutóbbiakkal együtt járó primadonnáskodásokkal. A sport elsősorban szellemi fogalom. Egy sportcsapat a társadalomnak kicsinyített képe, a mérkőzés az életért való nemes küzdelem szimbóluma. Itt a játék alatt tanítja meg a sport az embert rövid idő alatt a legfontosabb polgári erényekre: összetartásra, az önfeláldozásra, az egyéni érdek teljes alárendelésére, a kitartásra, a tettrekészségre, a gyors elhatározásra, az önálló megítélésre, az abszolút tisztességre és mindenekelőtt a "fair play", a nemes küzdelem szabályaira" (Szent-Györgyi Albert 1930).

A sportolás elsố társadalmi funkciója abban rejlik, hogy segíthet egy egészségtudatosabb életvitel kialakításában. A rendszeres mozgást végzők könnyebben beláthatják, hogy a sportolás mellett például az egészséges táplálkozásnak, az élvezeti cikkek mellőzésének is be kell épülni az életmódjukba. A sportolás további funkciója a rekreáció elősegítése. Segít a munkahelyi, iskolai ártalmak következtében kialakult fizikai és mentális problémák megoldásában. A kutatási eredmények azt mutatják, hogy a fittebb, egészségesebb szervezetnek nagyobb a teherbírása. Éppen ezért az oktatási intézményeknek tudatosítaniuk kell, hogy mekkora a felelősségük a fiatalok nevelésében annak érdekében, hogy minél nagyobb és jobb legyen a teherbírásuk (Kovács 2014b).

Mára már megcáfolhatatlan tény, hogy rendszeres testedzés nélkül nincs sem fizikai, sem lelki egészség, ezért fontos, hogy a fiatalok észrevegyék a sport személyiségformáló és értékadó szerepét. Ez a felismerés jelentős mértékben hozzájárulhat ahhoz, hogy a szocializáció során egyre egészségesebb legyen a fiatal generáció a sportoláshoz, a megfelelő mennyiségú és minőségủ fizikai aktivitáshoz (Kopp 1999). Különösen fontos a testnevelés és a sportolás egészségre gyakorolt hatásának, egészséges életmódra való szocializálásában betöltött szerepének vizsgálata Ukrajnában, hiszen statisztikai adatok igazolják az ukrán iskoláskorúak kifejezetten rossz egészségi állapotát. 
Az Ukrán Nemzeti Orvostudományi Akadémia adatai szerint az utóbbi tíz évben az iskoláskorú gyermekek megbetegedési arányszáma 27\%-kal emelkedett. Összességében az ukrán iskolások mindössze 7\%-ánál (!) állapítható meg, hogy szervezetük funkcionális állapota kielégítő, és az iskoláskorú fiatalok csupán 30\%-a (!) sportolhat korlátozás nélkül. Az iskolások 90\%-ánál diagnosztizálnak különböző megbetegedéseket. Lényegesen gyakoribbá váltak a gyermekek tartási rendellenességei. A fiatalabb generáció körében drasztikusan növekszik a krónikus szívbetegség, a magas vérnyomás, az idegrendszeri betegségek, a csontritkulás, az ízületi gyulladás, az elhízás stb. Ez a helyzet elsődleges jelentőségű állami problémává lépett elő, amely adekvát megoldást sürget (Keresztény \& Greba 2013). Ezek az eredmények pedig relevánssá tesznek egy olyan kutatást, amely a testnevelés és sportolás helyét, szerepét és presztízsét vizsgálja az ukrán középiskolások körében.

\section{Az ukrajnai (kárpátaljai) testnevelés és sport a rendszerváltás után}

A rendszerváltás után eltelt 25 év alatt az ukrajnai közoktatásban óriási változások történtek. Ezek az átalakítások jelenleg is zajlanak. Az 1992-ben elfogadott „közoktatásról” szóló törvény értelmében az iskolák autonómiát kaptak és lehetőség nyílt nem állami intézmények, nemzetiségi gimnáziumok, líceumok alapítására is. Kárpátalján a középiskolai oktatás 1-11 év $(4+5+2)$, a gimnáziumokban az 5-11. évfolyamon, a líceumokban a 8-11. évfolyamon zajlik a magyar nyelvü oktatás (is) (Az oktatásról...).

Az általunk is vizsgált régióban a 2014-es 15379 tanulói létszámhoz képest 2015-ben 15733 diák számára vette kezdetét magyar tannyelvű osztályban a tanév. Ami a régiókat illeti, a Felső-Tisza-vidéken 975 (tavaly 926), Ugocsában 2538 (tavaly 2453), Beregben 5643 (tavaly 5669), Ungban 3566 (tavaly 3317), a Munkácsi régióban pedig 3011 (tavaly 3014) volt a tanulói létszám. Ezek a számok sok mindenről árulkodnak. A történelmi Ugocsa, a mai Nagyszőlősi járás, lakosságának 25\%-a magyar, míg a Munkácsi járásnak csak 10\%-a, mégis több diák tanul a munkácsi körzet magyar osztályaiban, mint Ugocsában, ahol pedig kétszer annyi magyar tannyelvú iskola, osztály van (Orosz 2016).

Ukrajna függetlenné válása után néhány évig még a szovjetrendszerből átörökölt testnevelési programot használtuk. Az első, általános és középiskolákra kiterjedő, komplex testnevelési program 1998-ban jelent meg, de már ukrán nyelven, és a kötelező oktatási nyelv is az ukrán nyelv lett (A közoktatás testnevelési programja az 1-11. osztály részére, 1998).

A 2001-ben elfogadott legátfogóbb oktatási reform következtében a középiskolai tanulmányi idő 11 osztályról 12-re bővült, az értékelés pedig nem 1-5 pontig terjedt, hanem 1-12 pontig. Ez az oktatási reform komoly változásokat idézett elő a testnevelésben is: új 12 osztályra vonatkozó testnevelési tantervet kellett kidolgozni, teljesen át kellett alakítani az értékelési rendszert. Ez meg is történt, egyre-másra jelentek meg az újabb testnevelési és sportprogramok, szakkönyvek, különböző átdolgozott, központilag jóváhagyott és kiadott tantervek ukrán nyelven. 
2009-ben viszont, a következő kormányváltás után, Ukrajnában visszavonták azt a rendeletet, ami a 12 osztályos középiskolai tanulmányokat illeti, így jelenleg a 11 osztályos érvényes. Az értékelés, az értékjegyek megmaradtak 1-12 pontig. Viszont az alsó tagozatban heti két testnevelésóra helyett hármat irányoztak elö, az 5-6-7. osztályokban heti 2,5 óra, a 8-9. osztályban három óra, a 10-11. osztályban két-két testnevelésóra kötelező. Két évvel később, 2011-ben minden évfolyamon (1-11.) egyformán heti három-három testnevelésóra lett elfogadva. Ukrajna Oktatási és Tudományos Minisztériuma reformpolitikájának köszönhetően radikális szemléletváltás történt a testnevelés és a sport oktatása ügyében, valamint a versenysport fejlesztése terén. Kilátásba helyezték a mindennapos testnevelés bevezetését is.

\section{A testnevelés helyzete, szerepe a középiskolások körében}

A testnevelés tantárgy - a többi tantárgyhoz hasonlóan - sajátos múveltségtartalommal bír, és elsődleges célja ennek átadása. Ebből a szempontból egy a tantárgyak közül.Ugyanakkor egyetlen a tantárgyak közül, amely elsősorban (de nem csak!) a test, a fizikum fejlesztésével foglalkozik. Ezért nagy jelentőségú az ukrán oktatásügy azon törekvése, hogy az általános iskola valamennyi évfolyamán bevezessék a mindennapos (heti öt) testnevelésórát, illetve a középiskolákban is biztosított legyen a testedzés minden nap.

A múveltségtartalom sajátosságain túl a testnevelés tantárgynak az iskolai éveken túlmutató, kiemelkedő szerepe van az életmód alakításában. A testnevelésórán szerzett élmények, tapasztalatok, ismeretek - kiegészülve a családban, más tanórákon és a szabad időben szerzettekkel - alapozzák meg azokat a szokásainkat, amelyek életmódunk részévé válnak. Az egészséges életmód elképzelhetetlen megfelelő mennyiségü mozgás nélkül. Az élményt adó, önként vállalt mozgáshoz viszont megfelelő mozgásismeret szükséges. A mozgástanuláshoz nélkülözhetetlen képességek és készségek fejlesztése, illetve a sportmozgások alapjainak megismerése is az iskolai testnevelés keretében zajlik (Krucevics 2008).

Rétsági (2015) állitása szerint az egészségre nevelés területén a testnevelés mindig is kiemelt szerepet játszott. Ugyanakkor a mindennapos testnevelés bevezetésével a tantárgy új dimenzióba került, új minőséget hozhat létre, hiszen a megfogalmazott célok képessé tehetik a múveltségi területet tanítókat a hatékonyabb egészségnevelésre, az egészségkultúra alapjainak megteremtésére. A 2012-es NAT szerint a testnevelés múveltségterület kiemelt célja, hogy a rendszeres fizikai aktivitás minden tanuló életében komoly szerepet kapjon, hogy a tanulókat élethosszig tartó, egészségtudatos, aktív életvezetésre szocializálja (Makszin 2014).

Borbély (2014) országos reprezentatív kutatásában megállapítja, hogy a mindennapos testnevelés bevezetését a felnőtt lakosság (a szülők) többsége is szükségesnek érezte. Rétsági (2015) szerint a mindennapos testnevelés egyre nagyobb lehetőségeket teremt, és a tanórai testnevelés játssza a főszerepet a sport általi szocializációban. 
Többek között Mikulán (2013) is azt fejti ki tanulmányában, hogy hosszú távon a mindennapos testnevelés kedvező hatást válthat ki. Így meglátásunk szerint lényeges annak vizsgálata, hogy mit gondolnak a tanulók a tantárgyról. A szubjektív szempontok azonban egyértelmúen a program eredményességét mutatják, hisz a gyermekek többségének mozgástudatosságára motiválóan hat. Azonban nem sikerült bizonyítani, hogy a rendszeres testmozgással kialakul a napi szintủ sportolási igény szükségessége (Tózsa-Rigóné Németh 2011), de a heti öt testnevelésóra hozzájárul a tanulók fizikai teljesítóképességének emelkedéséhez (Vári et al. 2012, idézi Fintor 2016). Ezen eredmények alapján mi is célul túztük ki a kárpátaljai középiskolások testnevelésórákkal kapcsolatos attitüdjeinek vizsgálatát.

Elméletben mindenki tisztában van azzal, hogy mennyire fontos a gyermekek életében a testnevelés, a sport, a mindennapi mozgás. Úgy véljük, a gyermekek egészségnevelését a családi nevelésre építve elsősorban az iskolán belül lehet és kell megalapozni. A szülőkkel közösen az általános iskolában még nagy eséllyel lehetne egészségtudatos magatartást javítani, pótolni vagy jobb esetben csak csiszolni, finomítani. Kutatásunk célja az volt, hogy megkérdezzük az iskoláskorú tanulókat arról, hogy mennyire kedvelik a testnevelésórákat és hogyan viszonyulnak a sporthoz.

\section{Minta és módszerek}

Tanulmányunkban arra keressük a választ, hogy milyen lehetőségekkel, tartalmakkal jellemezhetők a kárpátaljai középiskolások testnevelésórái, hogyan viszonyulnak ezekhez a diákok, mi jellemzi sportolási szokásaikat, motivációikat, s mindezekben milyen társadalmi tényezők játszanak szerepet. A legfontosabb magyarázó változók a nem, az iskola járása (beregszászi, nagyszőlősi, ungvári és huszti), az évfolyam, a szubjektív társadalmi-gazdasági helyzet (átlag alatt és fölött), illetve a szülók iskolai végzettsége (alacsony, közép, magas) volt. Kutatásunk során kérdőíves felmérést készítettünk Kárpátalja négy magyar kisebbség által lakta járásának hét középiskolájában. Ezek között volt hagyományos 1-9 és 1-11 évfolyamos iskola, nyolc évfolyamos gimnázium és három évfolyamos líceum. A mintavétel során arra törekedtünk, hogy minden olyan járásból kiválasszunk egy-egy iskolát, ahol tömbben él a magyar kisebbség, illetve szórványtérségből is kerüljön be magyar tannyelvú iskola, de a minta nem tekinthetô reprezentatívnak. A lekérdezés során csoportosan végeztük a kérdőívek kitöltetését a 8., 9. és 10. évfolyamos diákok körében. Összesen 108 értékelhető kérdőívet kaptunk vissza az iskolákból. 


\section{A kutatás eredményei}

\section{A testnevelésórák jellemzôi}

Kutatásunkban egy 28 itemból álló kérdéssorral vizsgáltuk meg, hogy bizonyos kérdések, tartalmak milyen mértékben fordulnak elő a testnevelésórákon (1 egyáltalán nem ért egyet, 4 teljes mértékben egyetért az adott állitással). A legjellemzőbb tevékenység az órákon a játék, a diákok 93\%-a nyilatkozott úgy, hogy rendszeresen játszanak a testnevelésórákon. Ez azonban nem jelent változatos játékokat a diákok több mint fele szerint. A diákok több mint 70\%-a egyetért azzal, hogy a testnevelésórák megtanítanak a csapatban való együttmúködésre, a kudarc elviselésére, hallanak az egészségkárosító szerek negatív és a sportolás pozitív hatásairól, 80\%-a szerint az órák miatt egészségesebbek lehetnek, megfelelően értékelik teljesítményüket, és más órákhoz viszonyitva itt sikeresebbek lehetnek. Viszont ezért meg is kell dolgozni, hiszen a diákok több mint háromnegyede jól elfárad az óra végére (86\%), ugyanakkor ez nem hat ki a nap további részére 75,4\%-uk szerint. Szintén magas arányban (75\%) kiemelik a jó kapcsolatukat a tanárral és a jó hangulatot az órákon, amiben az játszik szerepet, hogy többségük nem tartja túl szigorúnak a testnevelő tanárt, s nem gondolja, hogy túl nehéz feladatokat ad a diákoknak más tanárokhoz viszonyítva. Ugyanakkor többségük (70\%) nem érzékeli, hogy ügyesedett volna a testnevelésórák hatására, nem néz emiatt több sportműsort, és a helyes táplálkozás sem kerül szóba kétharmaduk szerint, akárcsak a helyes életmód általánosságban véve (54,6\%). Jól látható, hogy a testnevelésórákon elsősorban a testmozgáshoz kapcsolódó pozitív élmények, tevékenységek kerülnek előtérbe, a nevelő funkció magához a sporttevékenységhez, még inkább a játékhoz kapcsolódik, és ezek lényegéből fakad (fair play, együttmúködés stb.), s hogy az egészséges életmódra való nevelés azon kívül, ami mindenképpen rontja a sportteljesítményt (káros szenvedélyek), háttérbe szorul. Az egyes állításokra adott válaszok megoszlásait az alábbi ábra tartalmazza. 


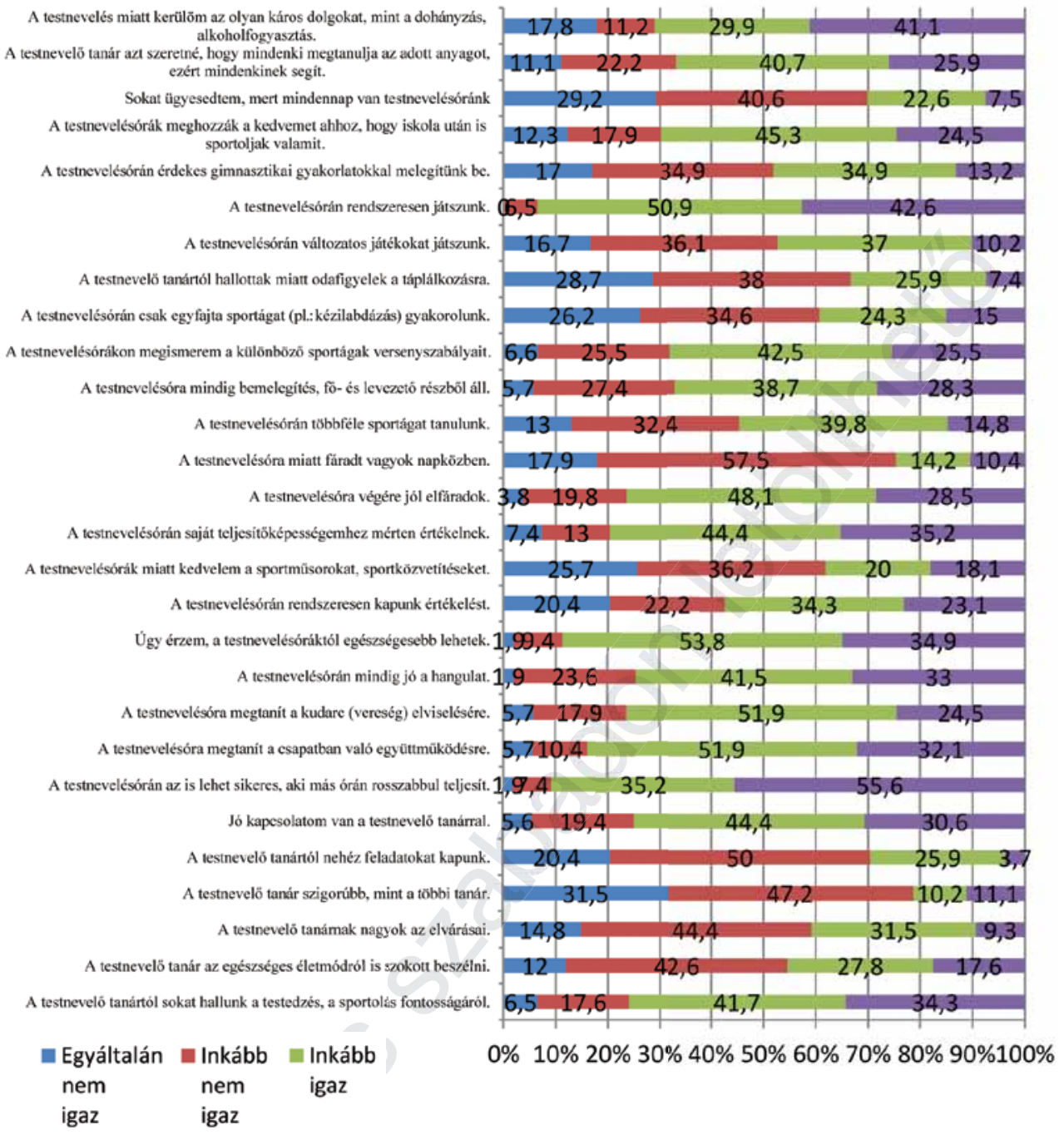

1. ábra. A testnevelésórák jellemzőinek itemeire adott válaszok megoszlása ( $\mathrm{N}=105)$ Forrás: saját kutatás

Fintor (2016) saját kutatásában a testnevelésórák jellemzőire adott állításokat klaszterelemzéssel csoportosította. Olyan csoportok jöttek létre, mint a tantárgyi ismeretek, az egészségtudatosság, a testnevelő szerepe, amelyek esetében az állításoknál átfedések nem megengedettek. Az állításokra adott válaszok átlagainak vizsgálatakor kiderült, hogy a diákok a legmagasabb átlaggal azt az állítást jelölték meg, amely a testnevelő segítőkészségét mutatja az elsajátítandó tananyaggal kapcsolatban, illetve a saját teljesítményük sikerességére utal. Hasonló pozitív eredmény bontakozott ki a kárpátaljai adatfeldolgozás során is, amikor az órát olyannak tekintik, amelyen bárki lehet sikeres, még az is, aki más tantárgyból gyengébben teljesít. Az Észak-Alföld 
régióban mért vizsgálat szerint a legkisebb átlagot az egy sportág megismerésére utaló állitás mutatta, amely azt igazolja, hogy a mindennapos testnevelésórák keretében a diákoknak valóban lehetőségük van többféle sportág megismerésére.

\section{A testnevelés jellemzöi faktorokra bontva}

Saját vizsgálatunkban faktorelemzéssel csoportosítottuk a jellemzóket. A faktorelemzés során ezek a jellemzők hét faktorba rendeződtek. Az első faktorban az egészséges életmódra nevelés jelenik meg, ezért így neveztük el. A második faktorban a testnevelésóra nehézségei jelennek meg, mint a szigorú tanár vagy nehéz feladatok. A harmadik faktorban a testnevelés személyiség-, képességfejlesztő és nevelő hatásai, az ott szerzett pozitív élmények jelennek meg, ezért a testnevelés pozitívumainak neveztük el. A negyedik jellemzőben a testi fáradtság kap szerepet, így a testnevelés miatti fáradtság nevet kapta. A következő, a testnevelés mint sport faktor az egyes sporttevékenységek típusainak és fázisainak megjelenését tartalmazza az órákon. A következő változót egyetlen item, a helyes táplálkozásra való nevelés alkotja a tanár által (a testnevelésóra hatása a táplálkozásra). Az utolsó faktort a testnevelésórán előforduló játékok, játékosság jellemzi (a testnevelés mint játék). A faktorsúlyokat a melléklet 1. táblázata tartalmazza.

\section{A testnevelés tartalmai társadalmi-demográfiai jellemzók mentén}

A továbbiakban megnéztük, hogy milyen különbségeket találhatunk a testnevelésórához kapcsolódó tartalmak mintázatai között a társadalmi-demográfiai tényezők mentén. Ha az iskolák járásai szerint vizsgáljuk meg a különbségeket, akkor azt láthatjuk, hogy két faktorban, a táplálkozás és a játék faktorában találhatunk szignifikáns különbségeket. Az egészséges életmódra való nevelés megjelenését a testnevelésórákon a legfiatalabbak érzékelik leginkább, s legkevésbé a 10. évfolyamosok. A testnevelésóra nehézségeit szignifikánsan nehezebben viselik az átlag alatt szubjektív anyagi helyzetben lévők, ők sokkal inkább kiemelik azt, hogy a testnevelésórákon nehéz feladatokat kell végezni, amelyek a számukra igen fárasztóak. Korábbi szakirodalmi kutatások igazolják, hogy a sportolásban erôteljes egyenlőtlenségek figyelhetők meg, s a sportban való részvétel tekintetében is hátrányos helyzetben vannak a rosszabb társadalmi-gazdasági helyzetben lévő́k (Földesiné \& Gáldiné 2008; Perényi 2011; 2013; Dóczi 2014; Kovács 2012; 2015a; 2015b). Azt feltételezhetjük, hogy esetünkben a rosszabb szociokulturális helyzetben lévő fiatalok kevésbé vesznek részt szervezett/rendszeres sporttevékenységben, így a kötelező testnevelésórákat is megterhelóbbnek érzékelhetik.

Az ungvári járási iskolák tanulói érzékelik leginkább a testnevelés hatását a táplálkozási szokásaikra, a huszti és nagyszőlósi járási iskolák diákjai pedig a legkevésbé. Ugyanakkor a nagyszőlősi járási iskola diákjai és a 9. évfolyamosok véleménye szerint jellemzi nagyon sok játék a testnevelésóráikat, a játékok, szabályok fontos szerepet töltenek be az órákon. Ebben az előbbi esetben a tornaterem hiánya játszhat szerepet, mert így az udvaron kell megoldani az órákat, télen pedig az osztályteremben, a 9.-esek esetében pedig a tantervi sajátosságok ezen az évfolyamon. A játékos foglal- 
kozások a beregszászi járási és 8.-osok szerint jellemzi legkevésbé az órákat. A többi változó és faktor mentén nem találtunk szignifikáns különbségeket. A faktorszkórok átlagait az alábbi, 1. számú táblázat tartalmazza.

1. táblázat. A testnevelésórák jellemző faktorainak átlagai a társadalmi-demográfiai tényezők mentén (faktorszkórok)

\begin{tabular}{|c|c|c|c|c|c|c|c|c|c|}
\hline & & $\begin{array}{l}\text { Egész- } \\
\text { séges } \\
\text { életmód }\end{array}$ & $\begin{array}{l}\text { Testne- } \\
\text { velésóra } \\
\text { nehéz- } \\
\text { ségei }\end{array}$ & $\begin{array}{l}\text { Test- } \\
\text { nevelés } \\
\text { pozití- } \\
\text { vumai }\end{array}$ & $\begin{array}{c}\text { Test- } \\
\text { nevelés } \\
\text { miatti } \\
\text { fáradt- } \\
\text { ság }\end{array}$ & $\begin{array}{c}\text { Test- } \\
\text { nevelés } \\
\text { mint } \\
\text { sport }\end{array}$ & $\begin{array}{c}\text { Test- } \\
\text { nevelés } \\
\text { hatása } \\
\text { a táplál- } \\
\text { kozásra }\end{array}$ & $\begin{array}{c}\text { Test- } \\
\text { nevelés } \\
\text { mint } \\
\text { játék }\end{array}$ & $\mathrm{n}$ \\
\hline \multirow{4}{*}{ 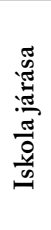 } & Beregszászi & $-0,21$ & $-0,11$ & $-0,10$ & 0,21 & 0,20 & $-0,11^{*}$ & $0,24^{*}$ & 33 \\
\hline & Ungvári & 0,25 & $-0,19$ & 0,23 & $-0,13$ & $-0,16$ & $0,38^{*}$ & $-0,23^{*}$ & 37 \\
\hline & Nagyszőlősi & $-0,18$ & 0,52 & $-0,005$ & $-0,36$ & 0,29 & $-0,29^{*}$ & $0,51^{*}$ & 14 \\
\hline & Huszti & 0,01 & 0,19 & $-0,24$ & 0,13 & $-0,23$ & $-0,31^{*}$ & $-0,33^{*}$ & 20 \\
\hline \multirow{3}{*}{ 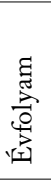 } & 8 & $0,22^{*}$ & $-0,09$ & 0,13 & $-0,01$ & $-0,12$ & 0,16 & $-0,29^{*}$ & 48 \\
\hline & 9 & $0,18^{*}$ & $-0,13$ & 0,20 & 0,13 & 0,24 & 0,13 & $0,85^{*}$ & 13 \\
\hline & 10 & $-0,30^{*}$ & 0,14 & $-0,13$ & 0,008 & 0,02 & $-0,20$ & $0,78^{*}$ & 42 \\
\hline \multirow{2}{*}{ 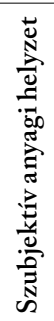 } & $\begin{array}{l}\text { Átlag alatt } \\
\text { v. átlagos }\end{array}$ & 0,0009 & $0,19^{*}$ & 0,09 & 0,004 & $-0,01$ & $-0,001$ & 0,001 & 69 \\
\hline & Átlag fölött & 0,002 & $-0,037^{*}$ & $-0,17$ & $-0,02$ & 0,04 & 0,03 & $-0,01$ & 34 \\
\hline
\end{tabular}

\section{A testnevelés kedveltsége}

A továbbiakban azt néztük meg, hogy hogyan viszonyulnak a testnevelésórákhoz a kárpátaljai diákok. Azt láthatjuk, hogy összességében szeretik, hiszen több mint 90\%uk nagyon szereti vagy szereti ezeket az órákat, s mindössze 10 középiskolás nyilatkozott úgy, hogy nem. A testnevelésórák iránti attitűdöket jól mutatja, hogy szokott-e hiányozni a diákoknak, ha elmarad. Adataink alapján azt mondhatjuk, hogy többségük pozitívan áll az órákhoz, mert mintegy kétharmaduk (65,7\%) szerint szokott nekik hiányozni, ha elmarad. Azok esetében, akiknek nem, a legfőbb ok, hogy nem szeret megizzadni (8 fö) vagy nem szeret átöltözni (6 fó). Ezekben az infrastrukturális lehetőségek hiánya is szerepet játszhat (nincs öltöző, zuhanyzó az iskolákban), hiszen minden harmadik válaszadó iskolájában még tornaterem sincs (29,8\%-uk jelezte, hogy nem tornateremben szokott lenni a testnevelésóra). 74, illetve 79,8\%-uk jelölte meg, hogy többségében a sportudvaron vagy az iskola udvarán tartják meg az órákat, 32,7\% 
nyilatkozott úgy, hogy az osztályban, 16,3\% szerint az iskolán kívüli területen (utcán), 13,5\%-uk szerint tornaszobában. A diákok 48,1\%-ának lehetősége van a település egyéb sportpályáját használni.

A testnevelésórák kedveltségének változóját 0-tól 100-ig tartó skálává alakítottuk át, ahol 0 jelöli, ha egy diák egyáltalán nem, 100 pedig, ha nagyon szereti az órákat, majd megnéztük a különböző társadalmi-demográfiai változók mentén a különbségeket. Azt láthatjuk, hogy a fiúk lényegesebben jobban szeretik a testnevelésórákat (82,4 pont), mint a lányok (62,5 pont), ami összhangban van korábbi a régióban és nemzetközi kutatási eredményekkel. Fintor (2014) az Észak-Alföld régióban mért kutatásában azt találta, hogy a testnevelés tantárgy kedveltségére adott válaszok átlagos értéke mindkét nem esetében magas. A nemek közti kedveltség esetében azonban szignifikáns eltérés mutatható ki hasonló módon, mint Kárpátalján. A kedveltség nemek közti különbsége igazolja azt, hogy a diákok esetében a fiúk magasabb fokú kedveltsége a testnevelés tantárgy iránti még mindig kiemelkedő a lányokéhoz képest, amit a korábbi szakirodalmi vizsgálatok is igazolnak. Hasonló módon vélekedik Hamar és Karsai (2008), akik keresztmetszeti elrendezésben vizsgálták a testneveléshez kötődő affektivitást. Ez alapján a fiúk elfogadóbb hozzáállást mutatnak, mint a lányok, továbbá a pozitív érzelmi telítettség elsősorban a lányok körében nagymértékben csökken az életkor előrehaladtával.

Évfolyamonként is szignifikáns különbségeket találtunk: az évfolyamok növekedésével egyre kevésbé kedvelik a kárpátaljai középiskolások a testnevelésórákat (77,6, 76,6 és 65,4 pont). Ebben az is szerepet játszhat, hogy a 10. évfolyamon már heti három testnevelést kell teljesíteni, amit talán tehernek tekintenek a diákok, fóleg, ha figyelembe vesszük, hogy ez az érettségi előtti utolsó évfolyam. Az ungvári és huszti járási iskolák diákjai szeretik leginkább az órákat (79,1 és 72,8 pont), s a nagyszőloosi diákok a legkevésbé $(59,1)$, ami ismét az infrastrukturális lehetőségek hiányára vezethető vissza. A beregszászi járási iskolások 69 pontot értek el. A társadalmi háttérváltozóknak nincs hatásuk ebben a kérdésben.

Fintor (2016) kutatásában a kialakított csoportoknál a testnevelés tantárgy kedveltsége szempontjából is vizsgálta az eredményeket. Megállapítható, hogy az eredmények hasonlóak a helyi vizsgálatok eredményeivel, vagyis a fiúk egyértelmúen jobban kedvelik a testnevelésórákat, mint a lányok. Azok, akik nagyon szeretik a testnevelés tantárgyat, a legmagasabb értékkel a testnevelő szerepét jelölték meg. Valószínúleg a testnevelő befolyása jelenik meg náluk leginkább motiváló tényezőként a tantárgyi kedveltség tekintetében. Azok, akik „csak” szeretik a tantárgyat, náluk a leginkább az egészségtudatosság szerepe emelkedik ki. Azok, akik nem szeretik az órákat, náluk a tantárgyi ismeretekre vonatkozó állítások jelennek meg magasabb átlaggal. Ők azok, akik leginkább kritikusai az órának, akiknek sok a tantárgyi ismeret, amit az órán kell elsajátítaniuk. Megállapítható, hogy a Szabolcs-Szatmár-Bereg megyei és a kárpátaljai vizsgálatok alapján a testnevelők szerepe, a testnevelés és sport jótékony hatása az egészségre kiemelten jelennek meg a tanulók válaszaiban. 


\section{A sportolás jellemzói a kárpátaljai középiskolások körében}

A továbbiakban azt vizsgáltuk meg, hogy mi jellemzi a kárpátaljai középiskolások sportolási szokásait. Azt láthatjuk, hogy a diákok több mint fele legalább háromszor sportol a testnevelésórán kívül (56,5\%), heti kétszer 21,03\%, egyszer 14,8\%, egyáltalán nem pedig mindössze nyolc fő. A nemek között találtunk szignifikáns különbséget a sportolás gyakoriságában: a fiúk körében nagyobb arányban vannak olyanok, akik hetente legalább háromszor (fiúk: 67,3\%, lányok: 46,45) vagy kétszer sportolnak (23,1\% és 19,6\%), viszont több lány mozog csak hetente egyszer (26,8\%, szemben a fiúk 1,9\%-ával), az egyáltalán nem sportolók körében pedig egyenlő számban vannak fiúk és lányok (7-7 fő).

Jól mutatja a rendszerváltás utáni diákélsport intézményrendszerének leépülését, főleg a perifériás térségekben, mint amilyen Kárpátalja is, hogy alig vannak olyanok, akik versenyszerűen sportolnának, mindössze nyolc fő (focista, teniszező, táncoló, kosárlabdázó, atletizáló, kézilabdázó), 14 fő iskolai sporttevékenységben, a többiek pedig hobbisportban vesznek részt (79,2\%). Szignifikánsan többen vannak a szabadidősportolók a 10. és 8. évfolyamon (90,7\% és 76\%), az iskolai és egyesületi versenysportban pedig a 9. évfolyamosok vesznek részt a leginkább (mindkét esetben 23,1\%). Más változókkal nem találtunk szignifikáns összefüggést.

De milyen tényezők játszanak szerepet a sportmotivációkban? A továbbiakban erre keressük a választ. Úgy tűnik, a sportmotivációjukban elsősorban emocionális tényezők játszanak szerepet, mert a diákok döntő többsége (84,5\%) ért egyet azzal, hogy azért sportol, mert megtetszett neki ez a tevékenység. Azonban az érett gondolkodás elemei is megjelennek motivációikban: 61,5\%-uk szerint azért sportol, mert hosszú távra gondolkodik, egész életében szeretne sportolni, s ehhez úgy vélik, minél hamarabb be kell építeni a rendszeres testmozgást mindennapjaikba. Az oktatási intézmények fontos szerepét igazolja az az eredmény, hogy ezután a legnagyobb arányban (47,6\%) azt jelölték meg, hogy az iskolában űzhető az általuk végzett sporttevékenység. A legkevésbé játszik szerepet a szülők jelenlegi sportolása és tanácsa (13,6\% és $28,3 \%$ szerint), illetve a tv $(26,2 \%)$.

A fiúk és a felsőfokú végzettséggel bíró szülők gyermeke számára erősebb motiváló erôvel bír a szülők tanácsa a sportolásra, ami jól mutatja azt, hogy ezek a szülők tudatosan nevelik gyerekeiket a sportolás fontosságára, s nagy valószínúséggel többet is tudnak áldozni erre, hiszen az átlag feletti anyagi helyzetben lévők esetében szintén erősebben megjelenik ez a motivációs tényező. Ez pedig jól igazolja a sportolás társadalmi, gazdasági és kulturális beágyazottságát (Földesiné \& Gáldiné 2008; Dóczi 2014). Szintén a fiúknak fontosabb a barátok sportolása, az iskolai lehetőségek, mint a lányoknak. Évfolyamonként is találtunk szignifikáns különbségeket: a 9. évfolyamosok között vannak a legnagyobb arányban, akik hosszú távon gondolkodnak a sportolással kapcsolatban, a 8. évfolyamosok között pedig olyan diákok, akik a tanárok, testnevelők hatására sportolnak. Szintén a tanárok szerepének van erőteljes hatása a 
diákok testnevelésórán kívüli testmozgásában az ungvári iskolások esetében, míg a beregszászi iskolások körében erőteljesebben jelenik meg a televízió és az internet hatása. A szignifikáns összefüggéseket mutató eredményeket az alábbi, 2. táblázat foglalja össze.

2. táblázat. A sportmotivációk és társadalmi-demográfiai háttérváltozók szignifikáns összefüggései (az igaz válaszlehetőségek százalékai) ( $\mathrm{N}=108)$

\begin{tabular}{|c|c|c|c|c|c|c|c|c|}
\hline & & $\begin{array}{l}\text { Mert a } \\
\text { szüleim } \\
\text { taná- } \\
\text { csolták }\end{array}$ & $\begin{array}{l}\text { Mert a } \\
\text { tanára- } \\
\text { im, test- } \\
\text { nevelö } \\
\text { taná- } \\
\text { rom, } \\
\text { edzőm } \\
\text { taná- } \\
\text { csolta }\end{array}$ & $\begin{array}{l}\text { Mert a } \\
\text { bará- } \\
\text { taim is } \\
\text { sportol- } \\
\text { nak }\end{array}$ & $\begin{array}{l}\text { Mert a } \\
\text { az isko- } \\
\text { lában } \\
\text { üzhető }\end{array}$ & $\begin{array}{l}\text { Mert a } \\
\text { televí- } \\
\text { zióban } \\
\text { megtet- } \\
\text { szett }\end{array}$ & $\begin{array}{l}\text { Mert az } \\
\text { inter- } \\
\text { neten } \\
\text { megtet- } \\
\text { szett }\end{array}$ & $\begin{array}{l}\text { Mert } \\
\text { hosszú } \\
\text { távon } \\
\text { gondol- } \\
\text { kodom, } \\
\text { egész } \\
\text { életem- } \\
\text { ben sze- } \\
\text { retnék } \\
\text { spor- } \\
\text { tolni }\end{array}$ \\
\hline \multirow[t]{2}{*}{$\mathrm{Nem}$} & Fiú & $\underline{39,2}$ & & $\underline{60}$ & $\underline{58}$ & e & & \\
\hline & Lány & 18,2 & & 32,1 & 37,7 & & & \\
\hline \multirow{3}{*}{$\begin{array}{l}\text { Anya } \\
\text { iskolai } \\
\text { végzett- } \\
\text { sége }\end{array}$} & Alap & 7 & & & & & & \\
\hline & Közép & $\underline{40}$ & & & 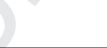 & & & \\
\hline & Magas & $\underline{50}$ & & C & & & & \\
\hline \multirow{3}{*}{$\begin{array}{l}\text { Apa } \\
\text { iskolai } \\
\text { végzett- } \\
\text { sége }\end{array}$} & Alap & 7,9 & & D & & & & \\
\hline & Közép & 34 & 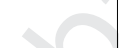 & 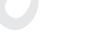 & & & & \\
\hline & Magas & $\underline{64,3}$ & $a \times$ & & & & & \\
\hline \multirow{2}{*}{$\begin{array}{l}\text { Szubjektív } \\
\text { anyagi } \\
\text { helyzet }\end{array}$} & Átlag alatt & 22,1 & $0 P$ & & & & & \\
\hline & Átlag felett & 39,5 & $P$ & & & & & \\
\hline \multirow[t]{3}{*}{ Évfolyam } & 8. & 3 & $\underline{49}$ & & & & & 49 \\
\hline & 9. & 0 & 15,4 & & & & & 76,9 \\
\hline & 10. & & 22 & & & & & 72,5 \\
\hline \multirow{4}{*}{$\begin{array}{l}\text { Iskola } \\
\text { járása }\end{array}$} & Beregszászi & & 15,7 & & & 36,4 & $\underline{57,6}$ & \\
\hline & Ungvári & & $\underline{50}$ & & & 24,2 & 29,7 & \\
\hline & Nagyszőlősi & & 30,8 & & & 8,3 & 33,3 & \\
\hline & Huszti & & 35 & & & 5 & 25 & \\
\hline
\end{tabular}

Forrás: saját kutatás

*Az aláhúzva közölt értékek arra utalnak, hogy a táblázat azon cellájába jóval többen kerültek, mint amennyi véletlen elrendeződés esetén várható lett volna. 


\section{Összegzés}

Tanulmányunkban megvizsgáltuk a kárpátaljai magyar középiskolások testneveléshez kapcsolódó attitűdjeit, a testnevelésórák tartalmi és formai jellemzőit, illetve a sportolási szokásokat. Azt láthatjuk, hogy a diákok döntő többsége szereti a testnevelésórákat, úgy értékelik, hogy fontos szerepet tölt be az egészséges életmódra való nevelésükben, a játék- és mozgásszükségleteiknek kielégítésében, s olyan sikerélmények elérésében, amiket más esetben (órákon) akár nem tapasztalnának meg. Kiemelkedő szerep jut a testnevelő tanárnak, aki a további sportolásra való ösztönzésben is fontos szerepet tölt be. A testnevelésórákhoz kapcsolódó kérdésekben elsősorban nemenként, iskolánként és évfolyamonként találtunk szignifikáns különbségeket, a társadalmi háttér szinte alig játszik szerepet. A sportmotivációkban azonban a magasabb kulturális és gazdasági tókével bíró szülőknek kiemelkedő jelentőségük van. Eredményeink hozzájárulnak ahhoz, hogy a testnevelésórák olyan pedagógiai tartalmakkal legyenek megtöltve, s olyan sportprogramok legyenek Kárpátalján, amelyek kielégítik a diákok igényeit, s ha ezekhez a megfelelő infrastrukturális és személyi háttér biztosított, akkor csökkenhet az oly magas fizikai problémákkal küzdő ukrajnai fiatalok aránya.

\section{Hivatkozott irodalom}

- Borbély, Sz. (2014). As parents see physical education (PE) from a representative survey's point of view. In Karlovitz J. T. (szerk.): Mozgás, környezet, egészség (pp. 39-54). Komarno, International Research Institue. Forrás: http://www.irisro.org/ health2014dec/14UrbinneBorbelySzilvia.pdf. Utolsó letöltés: 2015. 06. 20.

- Dóczi T. (2014). Sport és hátrányos helyzet. In Dr. Gál A., dr. Dóczi T., Sáringerné dr. Szilárd Zs. (szerk.): Társadalmi befogadás a sportban és a sport által (szociális inklúzió) (pp. 37-92). Budapest, Magyar Sportmenedzsment Társaság, Magyar Sporttudományi Társaság.

- Fintor G. (2014). Testmozgás a közösségben, avagy a mindennapos testnevelés jelenléte Szabolcs megyében. In Juhász E. (szerk.): Közösségi Múvelódés - Közösségi Tanulás (pp. 67-79). Debrecen, Debreceni Egyetem BTK, Neveléstudományok Intézete.

- Fintor G. (2016). Tanulói nézetek a mindennapos testnevelésről észak-alföldi általános iskolákban. In Kovács K. (szerk.): Értékteremtő testnevelés. Tanulói nézetek a mindennapos testnevelésről észak-alföldi általános iskolákban (pp. 24-35). Debrecen, Debreceni Egyetemi Kiadó.

- Földesiné Szabó Gy. \& Gáldiné Gál A. (2008). Válaszút előttt a sportpolitika. Magyar Sporttudományi Szemle, 9, 4-10.

- Hamar P. \& Karsai I. (2008). Az iskolai testnevelés affektív jellemzői 11-18 éves fiúk és lányok körében. Magyar Pedagógia, (2), 135-147.

- Kopp M. (1999). A mentálhigiénés megelózés alapelvei. Népegészségügy, 2 (80), 4-21. 
- Kovács K. (2012). The role and importance of sport in students' lives at the University of Debrecen. Hungarian Educational Research Journal, (1). Forrás: http://herj. $\mathrm{hu} / 2012 / 03 /$ kovacs-klara-a-sport-helye-es-szerepe-a-debreceni-egyetemistakeleteben/.Utolsó letöltés: 2016. 08. 31.

- Kovács K. (2014a).The Bologna Process in Ukraine. In Kozma T., Rébay M., Óhidy A. \& Szolár É. (eds.): The Bologna Process in East-Central Europe (pp. 321-354). Wiesbaden, Springer VS.

- Kovács K. (2014b). A sportolás, mint a tanulás és nevelés színtere. In Juhász E. (szerk.): Tanuló közösségek, közösségi tanulás - A tanuló régió kutatás új eredményei (pp. 213-236). Régió és oktatás X. Debrecen, CHERD-H.

- Kovács K. (2015a). A sportolás mint támogató faktor a felsôoktatásban. Oktatáskutatók könyvtára 2. Debrecen, CHERD-H (ISBN 978-963-473-810-7).

- Kovács K. (2015b). Magyarországi és romániai hallgatók sportolási szokásait meghatározó szociokulturális tényezők. In Kozma T., Kiss V. Á., Jancsák Cs. \& Kéri K. (szerk.): Tanárképzés és oktatáskutatás (pp. 673-685). Debrecen, Magyar Nevelés- és Oktatáskutatók Egyesülete.

- Krucevics, Т. J. (2008). Теорія і методика фізичного виховання [A testnevelés elmélete és módszertana]. Kijev, Olimpijszka literatura.

- Makszin I. (2014). A testnevelés elmélete és módszertana. Pécs, Dialóg Campus Kiadó.

- Mikulán R. (2013). Az iskolai testnevelés szerepe és jelentősége az egészségfejlesztésben. Ujj Pedagógiai Szemle, 63 (7-8), 48-69.

- Orosz I. (2005). A magyar nyelvú oktatás helyzete Kárpátalján az ukrán államiság kialakulásának elsó évtizedében (1989-1999). Ungvár, Poliprint.

- Orosz I. (2016). Oktatási innovációk lehetöségei Kárpátalján a kárpátaljai magyar nyelvülmagyar nyelvi oktatás helyzetének függrvényében. Nemzetközi Tudományos Pedagógiai-Pszichológiai Konferencia 2016. április 14-15., Beregszász.

- Perényi Sz. (2011). Sportolási szokások - Sportolási esélyek és változástrendek. In Bauer B. \& Szabó A. (szerk.): Arctalan (?) nemzedék. Iffúság 2000-2010 (pp. 159184). Budapest, Nemzeti Család- és Szociálpolitikai Intézet.

- Perényi Sz. (2013). Alacsonyan stagnáló mozgástrend: a fizikai inaktivitás újratermelődése. In Székely L. (szerk.): Magyar Iffúság 2012 (pp. 229-249). Budapest, Kutatópont.

- Rétsági E. (2001). Kézikönyv az iskolai testnevelés tanitásához (5-8 oszt.). Pécs, Dialóg Campus Kiadó.

- Rétsági E. (2015). MT - Minőségi Testnevelés, avagy Mindenki Testnevelése. Mindenki Testnevelése, avagy Minőségi Testnevelés (Elméleti alapok). In Révész L. \& Csányi T. (szerk.): Az iskolai testnevelés és sport tudományos alapjai (pp. 36-83). Budapest, Magyar Diáksport Szövetség.

- Szent-Györgyi A. (1930). Az iskolai ifúság testnevelése. Testnevelés, (3), 928-933.

- Keresztény I. \& Greba I. (2013). A tanulók egészségcsoportokba való besorolásának problémái. IV. Országos Tudományos-gyakorlati Konferencia „Pedagógia innovációk a szakoktatásban" tanulmánykötete (pp. 155-165). Ungvár, UNE. 
- Tózsa-Rigóné Németh J. (2011). A mindennapos testnevelés komplex programja Hódmezốvásárhelyen 2005-2009-ig: Megvalósulás, hatékonyságvizsgálat, szoftverfejlesztés. Doktori értekezés. Szegedi Tudományegyetem Neveléstudományi Doktori Iskola.

\section{Dokumentumok}

- Концепція Загальнодержавної цільової соціальної програми „Здорова нація” на 2009-2013 роки / Розпорядження Кабінету Міністрів України від 21 травня 2008 p. №731-p. [„A nemzet egészsége” 2009-2013 évben állami szociális program koncepciója. / Ukrajna Miniszteri Kabinetének határozata 2008. május 21. №731p.] Forrás: http://zakon2.rada.gov.ua/laws/show/731-2008-p. Utolsó letöltés: 2016. 08. 31 .

- Методичні рекомендаціі вивчення навчального предмета «Фізична культура»ЗНЗ у 2011/2012 навч. Році / Фізичне виховання у школі - №4.- 2011. [Módszertani útmutatók a testnevelés oktatásához a 2011/2012. tanévben / Testnevelés az iskolában. №4.-2011.]

- Інструкція про розподіл учнів на групи для занять на уроках фізичної культури / Наказ Міністерства охорони здоров'я України та Міністерства освіти і науки України від 20.07.2009 №518/674. [„A tanulók egészségügyi csoportokba való beosztása a testnevelési foglalkozásokon" / Ukrajna Egészségügyi Minisztériumának és Ukrajna Oktatási és Tudományos Minisztériumának határozata 2009. 07. 20. №518/674.] Forrás: http://zakon2.rada.gov.ua/laws/show/z0773-09. Utolsó letöltés: 2016. 08. 31.

- Про забезпечення медико-педагогічного контролю за фізичним вихованням учнів у загальноосвітніх навчальних закладах / Наказ Міністерства охорони здоров'я України та Міністерства освіти і науки України від 20.07.2009 №518/674. [Az oktatási intézmények tanulóinak orvosi ellenőrzésének megszervezése // Ukrajna Egészségügyi Minisztériumának és Ukrajna Oktatási és Tudományos Minisztériumának határozata 2009. 07. 20. №518/674.] Forrás: http:// zakon2.rada.gov.ua/laws/show/z0772-09. Utolsó letöltés: 2016. 08. 31.

- Програми для загальноосвітніх навчальних закладів “Фізична культура” 1-11 класи. (1998) [A közoktatás testnevelési programja a 1-11. osztály részére]. Kijev, Perun Kiadó.

- Концепція національного виховання // Київ, Рад. шк. - 1995.- №6.- С. 18-25. (1995) [A Nemzeti Oktatás Koncepciója]. Kijev, Radjanszka skola.

- Про освіту: Закон України зі змінами і доповненнями від 23 березня. -1996. №100 / 96 // Відомості Верховної Ради України. - 1996. - №21. -С. 253-278. [Az oktatásról: változások és bővítmények az Ukrán Törvényben. 1996. március 23. №100 / 96 // Az Ukrán Legfelsőbb Tanács közleménye. 1996. №21.- P. 253- 278.] 


\section{Melléklet}

1. táblázat. A testnevelésórák tartalmi jellemzőinek mintázata (faktorsúlyok) $(\mathrm{N}=108)$

\begin{tabular}{|c|c|c|c|c|c|c|c|}
\hline & $\begin{array}{l}\text { Egész- } \\
\text { séges } \\
\text { élet- } \\
\text { mód }\end{array}$ & $\begin{array}{l}\text { Test- } \\
\text { neve- } \\
\text { lésóra } \\
\text { nehéz- } \\
\text { ségei }\end{array}$ & $\begin{array}{l}\text { Test- } \\
\text { nevelés } \\
\text { pozití- } \\
\text { vumai }\end{array}$ & $\begin{array}{l}\text { Test- } \\
\text { nevelés } \\
\text { miatti } \\
\text { fáradt- } \\
\text { ság }\end{array}$ & $\begin{array}{l}\text { Test- } \\
\text { nevelés } \\
\text { mint } \\
\text { sport }\end{array}$ & $\begin{array}{l}\text { Test- } \\
\text { nevelés } \\
\text { hatása } \\
\text { a táp- } \\
\text { lálko- } \\
\text { zásra }\end{array}$ & $\begin{array}{l}\text { Test- } \\
\text { nevelés } \\
\text { mint } \\
\text { játék }\end{array}$ \\
\hline $\begin{array}{l}\text { A testnevelő tanártól sokat } \\
\text { hallunk a testedzés, } \\
\text { a sportolás fontosságáról. }\end{array}$ & 1,030 & & & & & & 3 \\
\hline $\begin{array}{l}\text { A testnevelő tanár } \\
\text { az egészséges életmódról is } \\
\text { szokott beszélni. }\end{array}$ & 638 & & & & & 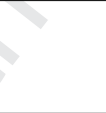 & \\
\hline $\begin{array}{l}\text { A testnevelő tanárnak nagyok } \\
\text { az elvárásai. }\end{array}$ & & $-1,031$ & & & & & \\
\hline $\begin{array}{l}\text { A testnevelő tanár szigorúbb, } \\
\text { mint a többi tanár. }\end{array}$ & &,- 581 & & & & & \\
\hline $\begin{array}{l}\text { A testnevelő tanártól nehéz } \\
\text { feladatokat kapunk. }\end{array}$ & &,- 362 & & 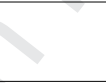 & & & \\
\hline $\begin{array}{l}\text { Jó kapcsolatom van } \\
\text { a testnevelő tanárral. }\end{array}$ & & & ,616 & & & & \\
\hline $\begin{array}{l}\text { A testnevelésórán az is lehet } \\
\text { sikeres, aki más órán } \\
\text { rosszabbul teljesít. }\end{array}$ & & & ,606 & & & & \\
\hline $\begin{array}{l}\text { A testnevelésóra megtanít } \\
\text { a csapatban való } \\
\text { együttmúködésre. }\end{array}$ & & & ,542 & & & & \\
\hline $\begin{array}{l}\text { A testnevelésóra megtanít a } \\
\text { kudarc (vereség) elviselésére. }\end{array}$ & 8 & & ,509 & & & & \\
\hline $\begin{array}{l}\text { A testnevelésórán mindig jó } \\
\text { a hangulat. }\end{array}$ & 3 & & , 474 & & & & \\
\hline $\begin{array}{l}\text { Úgy érzem, a testnevelés- } \\
\text { óráktól egészségesebb lehetek. }\end{array}$ & & & ,458 & & & & \\
\hline $\begin{array}{l}\text { A testnevelésórán rendszere- } \\
\text { sen kapunk értékelést. }\end{array}$ & & & ,422 & & & & \\
\hline $\begin{array}{l}\text { A testnevelésórák miatt } \\
\text { kedvelem a sportmúsorokat, } \\
\text { sportközvetítéseket. }\end{array}$ & & & ,418 & & & & \\
\hline $\begin{array}{l}\text { A testnevelésórán saját } \\
\text { teljesítőképességemhez } \\
\text { mérten értékelnek. }\end{array}$ & & & ,376 & & & & \\
\hline $\begin{array}{l}\text { A testnevelésóra végére jól } \\
\text { elfáradok. }\end{array}$ & & & & ,741 & & & \\
\hline $\begin{array}{l}\text { A testnevelésóra miatt fáradt } \\
\text { vagyok napközben. }\end{array}$ & & & & ,449 & & & \\
\hline
\end{tabular}




\begin{tabular}{|c|c|c|c|c|c|c|c|}
\hline & $\begin{array}{l}\text { Egész- } \\
\text { séges } \\
\text { élet- } \\
\text { mód }\end{array}$ & $\begin{array}{l}\text { Test- } \\
\text { neve- } \\
\text { lésóra } \\
\text { nehéz- } \\
\text { ségei }\end{array}$ & $\begin{array}{l}\text { Test- } \\
\text { nevelés } \\
\text { pozití- } \\
\text { vumai }\end{array}$ & $\begin{array}{l}\text { Test- } \\
\text { nevelés } \\
\text { miatti } \\
\text { fáradt- } \\
\text { ság }\end{array}$ & $\begin{array}{l}\text { Test- } \\
\text { nevelés } \\
\text { mint } \\
\text { sport }\end{array}$ & $\begin{array}{l}\text { Test- } \\
\text { nevelés } \\
\text { hatása } \\
\text { a táp- } \\
\text { lálko- } \\
\text { zásra }\end{array}$ & $\begin{array}{l}\text { Test- } \\
\text { nevelés } \\
\text { mint } \\
\text { játék }\end{array}$ \\
\hline $\begin{array}{l}\text { A testnevelésórán többféle } \\
\text { sportágat tanulunk. }\end{array}$ & & & & &,- 654 & & \\
\hline $\begin{array}{l}\text { A testnevelésóra mindig } \\
\text { bemelegítés, fö- és levezető } \\
\text { részből áll. }\end{array}$ & & & & &,- 459 & & \\
\hline $\begin{array}{l}\text { A testnevelésórákon } \\
\text { megismerem a különböző } \\
\text { sportágak versenyszabályait. }\end{array}$ & & & & &,- 448 & & \\
\hline $\begin{array}{l}\text { A testnevelésórán csak egyfaj- } \\
\text { ta sportágat (pl.: kézilabdázás) } \\
\text { gyakorolunk. }\end{array}$ & & & & &, 448 & 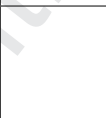 & \\
\hline $\begin{array}{l}\text { A testnevelő tanártól hallottak } \\
\text { miatt odafigyelek } \\
\text { a táplálkozásra. }\end{array}$ & & & & & & ,709 & \\
\hline $\begin{array}{l}\text { A testnevelésórán változatos } \\
\text { játékokat játszunk. }\end{array}$ & & & & & & &,- 593 \\
\hline $\begin{array}{l}\text { A testnevelő tanár azt } \\
\text { szeretné, hogy mindenki } \\
\text { megtanulja az adott anyagot, } \\
\text { ezért mindenkinek segít. }\end{array}$ & ,375 & & & & & &,- 439 \\
\hline $\begin{array}{l}\text { A testnevelésórán } \\
\text { rendszeresen játszunk. }\end{array}$ & & & & & & &,- 396 \\
\hline
\end{tabular}

Forrás: saját kutatás 



\section{Abstracts}

Pál Hamar, István Karsai, István Soós: Teachers' views on the contemporary issues of school physical education

Today, physical education is not one of the most popular subjects amongst students. Physical education teachers undertake a limited role only in "educating the body" of students that is due to a perceived lack of pedagogical knowledge. In our study, we investigated the circumstances of physical education teachers in comparison with other disciplines. We also aimed to learn whether central arrangements exist to provide a transition between compulsory physical education and extracurricular sporting activities. In our cross sectional research design, a questionnaire was used for data collection employing stratified group sampling $(n=1161)$. Our survey took place in the school year of 2013-2014. Data were analysed using descriptive statistics to identify frequencies of data, Chi-square and Fisher Exact tests were then employed to test for significance. The respondents' positions suggested that the status of physical education sits below that of other teaching disciplines. According to a quarter of the PE teachers sampled, their circumstances are worse than those of other teachers. Furthermore, the transition between compulsory $\mathrm{PE}$ and extracurricular sports is not satisfactory.

GÁbor Fintor: Students' views about everyday physical education in elementary schools of the Region of the Northern Great Plain

In Hungary, introduction of everyday physical education was considered to be a significant change in educational policy regarding physical education in schools. Therefore, the main aim of our work is to uncover the changes of the "Physical education and sports" content area. On one hand, we were analyzing the popularity of physical education as school subject. On the other hand, conforming to the goals of the NAT 2012 (National Core Curriculum), we were seeking the answers to the question what kind of positive and negative values and attitudes are present among the school children in connection with everyday physical education $(n=1074)$.

Our results clearly show that a very high percentage of students (95\%) like physical education classes. However, we discovered significant differences when examining this question separating genders; boys like physical education notably more $(p=0,000)$. The role of physical education teachers and educators, acting as motivating factors appear with outstanding importance in our survey. 


\section{László Balogh, Minály Kiss: Which way to go PE teacher training?}

Tha main purpose of this study to define and identify the goals of physical education teacher everyday physical education lessons, and possible implications for the future. Thus, we hope we may contribute to the mutual cooperation of experts from other co-sciences who are interested in physical education.

Róbert Orosz, Péter Jónás: New generation - New approaches and ways in sport talent management

The aim of the study is to describe changes in talent management that are necessary as a result of the complex development of systems in sports from the view of educational psychology by investigating sports in a wider context. Since different generations have different psychological characteristics, different educational psychological approaches might be necessary while dealing with them. In this study we introduce some psychological theories on the basis that we consider doing sports an important part of life, as it supports individual self-actualization during the development of systems. We also describe concepts dealing with characteristics of personal psychological and social behaviour that are typical of different generations. These concepts confirm that each generation has its own different psychological characteristics, therefore a change in approach is necessary. We make a difference between pedagogical approaches focusing on development and performance, and approaches focusing on the need of self-actualization and expectations. Finally, as an example of an integrative approach on talent management we describe a practical program: a camp for people talented in sports, organized as part of the programme, Tehetséghidak' (bridges of talent), since it focuses both on development and self-actualization.

ImRe FenYő, Dávid RábaI: Law environment of sport talent management - the sport academies in Hungary

The aim of this study is to examine the law environment of football academies in Hungary and documents indicated on the website availability, particularly with regard to the existence of the deed of foundation. In addition, our aim is still to analyze the attitude of the Hungarian Football Federation (henceforward HFF) towards academies from the aspect of what documents available even for them they make references with to the operation and regulation of academies. Our question is whether the HFF makes any reference to the legal embeddedness of academies, if yes, in what way. Another further research question is what quality of website football academies have, and if there are considerable differences between academies, mainly considering the question of recruitment. As a method we used document analyses, we reviewed the websites of football academies and the documents of HFF access to public, and the public education Act.

Based on our research results it can be claimed that there are only few academies that make their memorandum accessible and readable, besides HFF makes only a reference to the academies in a document. In terms of the websites of academies also great differences were observed, some academy has not its own website, either. 
István Kresztény, Ildikó Greba: Analysis of student ranking in PE categories in a Transkarpathian school

The article deals with current problems of physical training which are related to the health of younger school age children, the distribution of the learning process groups and their imperfections with a case study based on a teaching observation. In addition, the article deals with the most frequent disease of children of special and preparatory groups and with the implementation of a differential approach during special and preparatory groups.

Ilona Bodnár, Szilvia Perényi: Value network around the school Physical Education

The introduction of daily physical education - in addition to its effect on physical condition of children and youth - was also supported by the belief that sport has a capacity to contribute to the development of social and moral values. The value system around physical education has a decisive role in formulating students' experiences of moving and the joy of moving. Specifically, whether sport is good or bad for them, it represents a value for them or not. The values directly transferred, lifelong sustainability of sporting activity and the development motion wealthy lifestyle and automation of the transfer is in the center of attention. This paper in connection to the introduction of daily physical education uses social science theories, national and international research findings to challenge these issues and build bridges to practical implementation.

SzILvia Borbély: Prestige of physical education teachers and physical education as school subject in the changed environment of body culture

In 2002, one third of the whole population in Hungary thought that teachers and educators have very high influence on how the future of Hungary will be formed in the next decades (Cs. Czahesz \& Rado 2003). Besides the general assessment of the role and situation teachers occupy, which includes the survey of professional prestige of different teachers groups, we especially emphasize the assessment of physical education teachers, which is explained by their significance following the introduction of everyday physical education in 2012. With assigning different jobs and professions to a certain hierarchy, we are presented with a symbolical power which shows us the "symbolical", or, real power of different professions. The prestige hierarchy can only be interpreted in such circumtances where for example those of lower status respect those of higher status, they seek their company and they treasure these connections. Those human contacts that are formed during the symbolic formation of prestige can be beneficial for those affected, they can be helpful in forming styles, and in return, these can also be used for converting them and using them in order to further increase prestige (Léderer 1977; Maár 2002).

The aim of our survey is to examine what kind of prestige physical education teachers and physical education as school subject have in this changed environment; besides, we also aim to know whether there is consensus in connection with the agreement on the introduction of everyday physical education in different fields of education. Our 
survey was conducted in the spring of 2016 in educational institutions of the Region of the Nothern Great Plain, with the help of a self-made questionnaire $(n=230)$ in connection with the prestige of teachers and educators, and the social acceptance of everyday physical education and other school subjects.

Our results show that regarding the social acceptance of different professions those that usually appear in professional literature are also prominent here, although there is no visible sign of the hierarchy of different educational levels. Furthermore it can be stated that educators and teachers underestimate themselves when assessing the social acceptance of their profession. Also, the recognition of physical education as school subject and the extent of acceptance of everyday physical education show significant differences among those who teach physical education and those who teach other subjects.

Ágoston Nagy, Gábor Fintor, Szilvia Borbély: Effect of body culture changing on activity profile of university $P E$ teachers

This study aimed to monitor the physical education of the recent higher education, since the students of the first wave of the everyday physical education just hits the University of Debrecen. It is more than expectable that the body culture must face to new challenges while the P.E. teachers of the university must handle the huge interests. The teachers' activity profile has been getting changed nowadays.

Our goal is to get new prospect about the tasks of the education, trends and effective teaching methods. We do look for the answer if we could redefine the teachers' activity profile. The University of Debrecen is very significant in the geographical and social region. The gained survey data from its teachers and students helped us to get info about their customs and activities. We also made interviews with the P.E. teachers.

The new generation who has been just arriving from the everyday physical education and sports offers new researching areas. (1) The teachers' activities are effective. (2) The system of the education and the teaching - learning procedures have changed. There is a new program where the service and the inclusive teaching are in the main focus, where the role of the teachers are more valuable and the leadership is rather featured with the new way of coaching. So the P.E. departments must meet the new philosophy and concepts of the student-friendly programs. (3) At this aspect the university sport gets closer to educate students who are mainly involved living more healthy and active.

Gabriella Hideg: Fair Play - what does it mean for you? Opinion of youth about the concept in Carpathian Basin

The concept of fair play originally comes from sport, which has become nowadays an internationally known concept. It is presented in business, politics and social life at all levels, and of course in sport as well.

The national literature can be considered poor on this subject, but in the international literature we are able to find studies engaged with the measurement of fair 
play attitude. These studies typically are built around a fair play program, which are designed to demonstrate through the development and implementation of programs that the sportsmanship behaviour can be learned and taught.

The present study aims to investigate and introduce what the young people of Carpathian Basin think about the concept. What meanings do they attach to the fair play and how do they respond in different competition situations?

As the method of data collection a survey was conducted, whose sampling, process was based on random selection, and three higher education institutions 145 students filled in the questionnaire. The respondents included Romanian, Ukrainian and Hungarian youth. The questionnaire contains 17 questions, of which 15 are closed and two are open-ended questions. Questions covered the meaning content of fair play, interest in sport, and judgement of responses and actions during different competitive situations as well.

As a result, it can be said that the surveyed young people of three countries connect positive markers to the concept of fair play, and they demonstrate sportsmanship behaviour in different competitive situations.

\section{Beáta Erika Nagy, Karolina Eszter Kovács: Adolescents' health behaviour according to sport and family structure}

Health awareness plays an important role in our life. It is important to live an appropriate lifestyle because adequate way of life helps to conserve the optimal health status and to prevent chronic diseases (Conner 2005). The role of the family and parents is still significant. Children turn toward their peers but the family stands in the background as a supporting basis (Kovács \& Pikó 2009). However this function cannot be fulfilled with the crisis and disintegration of family structure which can mean a serious stressor, so it can increase the appearance and in serious case the longlasting subsistence of harmful health behaviour (Bramlett \& Blumber 2007). The aim of the study is to measure the appearance of smoking, getting drunk and substance use depending on sport and family structure in three counties on the basis of FASCES 2015. According to the results only pursuing sport does not influence the testing rate but it can be seen as a protective factor. Family structure considered on its own is not a significantly influencing factor but the mediating role of social factors are well perceptible in case of smoking, getting drunk and using joints.

KLÁra Kovács: Social-cultural characteristics of Central and Eastern European students'sport activity

The aim of our study to introduce the determining factors of students' sporting habits in the Region of the Nothern Great Plain in Hungary and beyond the borders Higher Education institutions. In the research mostly the Hungarian students from three Hungarian insitutions and three from Transylvania, two from Partium (Romania), two from Upper Hungary (Slovakia), three from Transcarpathia (Ukraine) and one from Vojvodina (Serbia) were examined. The sample was collected proportionally 
by the student number of institutions ( $N=2017)$. In sum we can see that the frequency of regular sporting students is very low in all examined countries, students do sport only weekly in general. If we examine the social and individual factors of students sporting habit in a model, we can see significant inequalities by gender and material status in Hungary, Romania (mostly) and Ukraine as well. The masculine dominance and dependency on material status of sport are prevailed mostly in these regions. If we examine the effects of attitudes and life-style as subjective elements, the influence of gender is disappointing, and the influence of subjective social status is prevailed among Transcarpathian students. The highest effect has the health-promoting attitude of sport as motivation.

Miklós Kozma, Ágnes Szabó, Péter Huncsik: The leisure sport consumption patterns of university students in Budapest - 2004-2014

Our paper explains the leisure activity and sport consumption patterns of university students in Budapest, based on four separate studies. The online survey prepared by Bíbor Béka civil initiative aimed to explore how university students in Budapest spend their leisure time, are engaged in sport activities, what motivates them to do sports, what sports they choose. This survey, conducted in 2014, asked similar and also additional questions to Szabós surveys of 2004, 2006 and 2010. First we highlight the results of pertinent local and international research projects. Then, our results are explained, highlighting the increasingly important role of doing sport as a leisure activity over the examined 10 years period. In line with information found in secondary sources, our primary results confirmed that the key motivation factors are improved health and fitness, as well as achieving a more attractive shape. Individual sports especially running, going to the gym, aerobic - are gaining popularity, particularly those that do not require much re-qualification or specific infrastructure. Our results show different patterns by sports and sexes. The practical implication of our results is that the supply of leisure sport facilities may be refined to the real needs of university students, both for non-profit and for-profit organisations.

Josip Lepes, Szabolcs Halasi, Anita Stajer: Effects of Physical education and Sport on healthcare in Vojvodinaian youths' attitudes

Hypokinesia as a general social phenomenon occurs at early age. The lack of movement on the human body have serious health consequences of obesity, cardiovascular diseases, incorrect posture, diabetes, etc. By doing regular exercise you can avoid not only these diseases but also can improve your endurance and well-being, quality of life, etc. The aim of the research was to examine university students' physical activity and their attitudes. The daily physical activity of 116 students ( $23 \mathrm{female}, 93$ male) of Subotica's Teacher Training Faculty in Hungarian filled in a questionnaire on health, eating, unhealthy habits and sedentary lifestyles, out of which 10 students were wearing the Polar watches which helped examine their daily physical activity. Students positively evaluated the effect of physical education and physical activity to health, 
yet $35 \%$ of them are not engaged in any type of physical activity and on average they spend 8 hours and 44 minutes in sedentary lifestyle on a daily basis.

\section{BEÁta DоваY: Recreational sport activities among Slovak adult population}

Our goal was to present the opportunities for the middle aged adults for recreational sport activities and show the gender differences within 3 regions in South Slovakia (Komárno, Nové Zámky and Dunajská Streda). We have used questionnaires, where we had help from professionals of Granada University who developed a questionnaire. The questionnaire was filled out by $n=742$, from which $n=339$ men, $n=403$ women. Besides the overview of foreign and local literature, we have used several programs for the evaluation of our questionnaires. We have used for the chi square setting the Pearson correlation and Statistics Program for Social Sciences calculations. The average age for women was 37,2, for men 36,5. We have assessed the ways how people reach recreational sport destinations, where $72,9 \%$ of men owns vehicles which they can use to get to these destinations. For this question there was a significant $(p<0,01)$ difference between genders. We have asked how much money they wish to spend on recreational sport activities. Men would spend more on recreational sport. Here we have experienced again a significant $(\mathrm{p}<0,01)$ difference between genders. We are comparing several gender differences with regards of different sports activity related questions. Within our recommendations we would like to draw attention to physical activities which could be exercised as recreational activities in nature.

Greba Ildikó, Greba Anna: The position of prestige of physical education and sports in the Hungarian secondary schools at Transscarpathia

Over the 25 years after the regime change tremendous changes have taken place in the Ukrainian public education. These adjustments are currently ongoing. According to these changes, that play a crucial role in a school-age child's life, even only indirectly way, aroused our interests to observe the prestige of sport and physical education. We have conducted a survey among the pupils of the Hungarian secondary schools in Transcarpathia with the aim to find out the attitudes of pupils to sports and physical education, and what factors influence it.

The results of the survey show that the perception of the physical education lessons and teachers are positive among the pupils. Regarding to doing sport, we can say that most parts of the pupils do some kind of sports, maybe as a hobby. When the differences of sporting habits between genders are taken into consideration, boys are more likely do sports. Thus pupils' sport activities originate not only from a controlled and organized framework but it is also realized in the form of a self-motivated leisure sport.

Overall we can say that the position of prestige of $\mathrm{PE}$ among pupils in the secondary schools in Transcarpathia is high, because pupils' attitude towards the physical education lessons are positive and the proportion of pupils who do sports regularly, several times a week is high. 



\section{Szerzőink}

Balogh László PhD habil., egyetemi docens, igazgató, Debreceni Egyetem Sporttudományi Koordinációs Intézet; elnök, Magyar Rektori Konferencia Sporttudományi Bizottság. balogh.laszlo@sport.unideb.hu

Bodnár Ilona PhD, könyvtárvezető, Eötvös Loránd Tudományegyetem Tanító- és Óvóképző Kar. bodnar.ilona@tok.elte.hu

Borbély Szilvia tanársegéd, Nyíregyházi Egyetem Testnevelési és Sporttudományi Intézet. urbinneszilvi@gmail.com

Buhaș, Sorin Dacian PhD, lecturer, University of Oradea, Faculty of Geography, Tourism and Sport, Department of Physical Education, Sport and Kinetotheraphy. sorin.buhas@gmail.com

Dobay Beáta PhD, tanszékvezető, Selye János Egyetem - Komárom, Testnevelés Tanszék.dobayb@ujs.sk

Fenyő Imre PhD, adjunktus, Debreceni Egyetem BTK Nevelés- és Múvelődéstudományi Intézet. fenyoimre@gmail.com

Fintor Gábor PhD-hallgató, Debreceni Egyetem BTK, Nevelés- és Múvelódéstudományi Doktori Program. fintor.gabor@gmail.com

Greba Anna oktató, II. Rákóczi Ferenc Kárpátaljai Magyar Főiskola Pedagógia és Pszichológia Tanszék. anci@kmf.uz.ua

Greba Ildikó oktató, II. Rákóczi Ferenc Kárpátaljai Magyar Főiskola Pedagógia és Pszichológia Tanszék.zildiko7@kmf.uz.ua

Halasi Szabolcs MSc, asszisztens, Újvidéki Egyetem Magyar Tannyelvű Tanítóképző Kar Didaktika és Módszertani Tanszék, Szabadka. sabolc.halasi@magister. uns.ac.rs

Hamar Pál PhD habil., intézetigazgató egyetemi tanár, Testnevelési Egyetem Tanárképző Intézet. hamar.pal@tf.hu

Hideg Gabriella PhD-hallgató, Pécsi Tudományegyetem BTK, „Oktatás és Társadalom” Neveléstudományi Doktori Iskola. hideggabriella87@gmail.com

Huncsik Péter alapító, Bíbor Béka. peter@biborbeka.hu

Jónás Péter PhD-hallgató, Debreceni Egyetem BTK, Pszichológia Doktori Program. sajtmester88@gmail.com

Karsai István PhD, adjunktus, Pécsi Tudományegyetem Általános Orvostudományi Kar. istvan.karsai@aok.pte.hu 
Keresztény István PhD, fóiskolai docens, Debreceni Egyetem GYFK Szociálpedagógia Tanszék. keresztenyi@ped.unideb.hu

Kis Mihály igazgató, testnevelő tanár, Grosics Gyula Sport Általános Iskola, Budapest. kismihaly61@gmail.com

Kovács Karolina Eszter PhD-hallgató, Debreceni Egyetem, Nevelés- és Múvelödéstudományi Doktori Program. karolina92.kovacs@gmail.com

Kovács Klára PhD, adjunktus, Debreceni Egyetem EK Szociális és Társadalomtudományi Intézet; kutató, DE Felsőoktatási Kutató és Fejlesztő Központ (CHERD-H). kovacs.klarika87@gmail.com

Kozma Miklós PhD, adjunktus, Budapesti Corvinus Egyetem Üzleti Gazdaságtan Tanszék.miklos.kozma@uni-corvinus.hu

Lepeš Josip PhD, egyetemi docens, dékán, Újvidéki Egyetem Magyar Tannyelvű Tanítóképző Kar, Szabadka. lepes@tippnet.rs

Nagy Beáta Erika PhD habil., egyetemi tanár, Debreceni Egyetem ÁOK Gyermekklinika.drbeatanagy@gmail.com

Nagy Ágoston PhD, adjunktus, Debreceni Egyetem Sporttudományi Koordinációs Intézet.gusti@med.unideb.hu

Orosz Róbert PhD, tanársegéd, Debreceni Egyetem Pszichológiai Intézet. ororobert@gmail.com

Perényi Szilvia PhD, adjunktus, Debreceni Egyetem GTK Sportgazdaság és -menedzsment Tanszék. sperenyi@hotmail.com

Rábai Dávid PhD-hallgató, Debreceni Egyetem BTK, Nevelés- és Művelődéstudományi Doktori Program. david.rabai@gmail.hu

Soós István PhD habil., associate professor, University of Sunderland, Faculty of

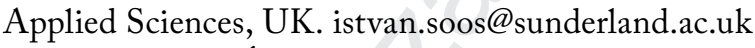

Stajer Anita MSc, Újvidéki Egyetem Magyar Tannyelvủ Tanítóképző Kar, Testnevelés Kutatócsoport, Szabadka. stajerani@gmail.com

Szabó Ágnes PhD, adjunktus, Budapesti Corvinus Egyetem Üzleti Gazdaságtan Tanszék. agnes.szabo2@uni-corvinus.hu 


\section{A sorozat várható tagjai}

2. Pusztai Gabriella és Márkus Zsuzsanna szerk.

Szülőföldön magyarul

3. Bacskai Katinka szerk.

A felekezeti oktatás negyedszázada 
